\title{
ECOSYSTEMS OF THE EAST SLOPE OF THE FRONT RANGE IN COLORADO*
}

\author{
BY \\ John W. Marr \\ Assoctate Professor of Brology \\ AND \\ Director of the Institute of Arctic \\ and Alpine Research \\ University of Colorado
}

\author{
University of Colorado Studies \\ Series in Biology \\ No. 8 \\ University of Colorado Press \\ Boulder, Colorado, November, ig6 1 \\ Price $\$ 2.50$
}

- Contribution from the Institute of Arctic and Alpine Research 


\title{
UNIVERSITY OF COLORADO STUDIES
}

\author{
Editor: KARL K. HסLLEY \\ Editorial Board: Floyd K. Basketre, Robert E. Gregc, Clay P. Malick, \\ Paul V. Thonpson, Harolo F. Walton
}

Numbers of the UNiversiry of Colorado Studies are issued from time to time as suitable contributions are received from members of the Faculty, preference being given to articles which may be (1) too long for publication in the usual journals, (2) not quite suited to any other journal, or (3) concerned especially with Colorado.

Established as an outlet for such materials as are mentioned above, the Studies was first published in January, 1902. Since that time, two changes have been made for the purpose of unifying the content of the several issues, the first having been effected in the academic year 1938-1939, when the Studies was divided into four series, three of which were limited to articles in some broad field of knowledge - humanities, social studies, and physical and biological sciences. The second change was made in the academic year 1947-1948, when the series were revised so as to limit each one to a particular field, as indicated in the list on the fourth page of the cover of this number.

It is requested that all exchanges be addressed to Serials Division, University of Colorado Libraries, Boulder, Colorado - not to the Editor.

Educational institutions, libraries, and societies desiring to be placed on the exchange list should make request to the Editor of University o, Colorado Studies, Boulder, Colorado. Business communications also shoulc be sent to the Editor. 


\section{CONTENTS}

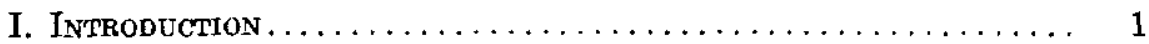

II. The Unit of Study and Its Characteristics ........... 6

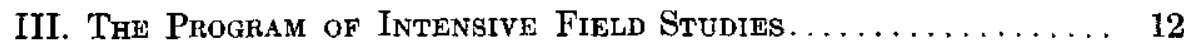

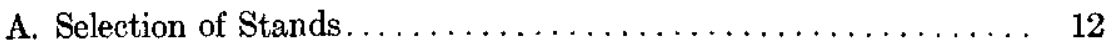

B. Environment Measurements .................... 12

1. Status of Knowledge of Mountain Environment........ 12

2. Factors to be Measured . . . . . . . . . . . . . . . 14

3. Instrumentation. . . . . . . . . . . . . . . . . . . 14

4. Methods and Procedures.................... 15

5. Preparation of Summaries.................... 16

C. Study of Vegetation......................... 17

IV. Regional Features of the front Range.............. 19

A. Geography and Geology . . . . . . . . . . . . . . . . 19

B. Climate and Weather $\ldots \ldots \ldots \ldots \ldots \ldots \ldots, 20$

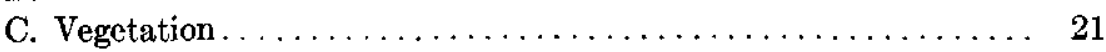

D. Regional Ecosystems . . . . . . . . . . . . . . . . . . . 23

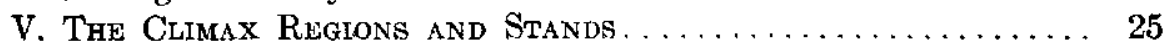

A. The Lower Montane Forest Climax Region . . . . . . . . . 25

1. Regional Characteristics.................... 25

2. The Major Stand-Types...................... 28

a. Ponderosa Pine Stand Complex ............... 28

b. Douglasfir-Ponderosa Pine Stand Complex........... 35

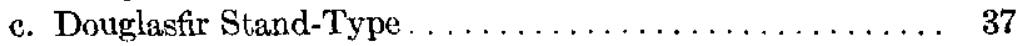

d. Grassland Complex........................ 37

e. Valley Floor Stand-Types................... 37

B. The Upper Montane Forest Climax Region . . . . . . . . . . . 39

1. Regional Characteristics.................... 39

2. The Major Stand-Types..................... 41

a. Douglasfir-Ponderosa Pine Complex ............. 41

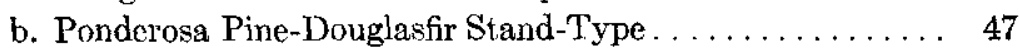

c. Douglasfir Stand-Type ................... 48

d. Ponderosa Pine Stand Complex. ............... 50

e. Limber Pine Stand-Type . . . . . . . . . . . . . . . 50

f. Aspen Stand Complex................... 50

g. Lodgepole Pine Stand-Type................. 51

h. Valley-Floor Stand-Types................... 51 
C. The Subalpine Forest Climax Region $\ldots \ldots \ldots \ldots \ldots \ldots \ldots, 53$

1. Regional Characteristics.................... 53

2. The Major Stand-Types................... 56

a. Spruce-Fir Stand-Type................... 56

b. Lodgepole Pine Stand-Type.................. 58

c. Aspen Stand-Type...................... 65

d. Limber Pine Stand-Type. . . . . . . . . . . . . . . 69

e. Willow-Birch Stand-Type.................. 74

f. Wet Sedge-Grass Meadow Complex............... 74

g. Dry Subalpine Meadow Stand-Type............. 75

D. The Alpine Tundra Climax Region ................ 75

1. Regional Characteristics..................... 75

2. The Major Stand-Types.................. 81

a. Kobresia Meadow Stand-Type . . . . . . . . . . . . . 83

b. Hairgrass Stand-Type..................... 86

c. Parry's Clover Meadow Stand-Type............. 88

d. Adoneus Buttercup Stand-Type. . . . . . . . . . . . 90

e. Snowbank Complex....................... 92

f. Cushion Plant Stand-Type................... 92

g. Dryas Stand-Type...................... 92

h. Sedge-Grass Wet Meadow Stand-Type ........... 93

i. Willow-Sedge Hummock Stand-Type.............. 94

j. Tundra Valley Stands..................... 95

VI. Summary................................. 101

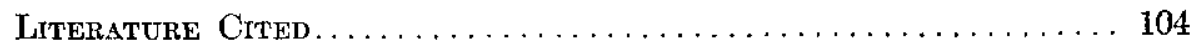

Appendix I. List of Plant Species . . . . . . . . . . . . . . . . . 110

Appendix II. Summaries of Environment Data ............. 119 


\section{LIST OF PHOTOGRAPHS}

Frontispiece. Aerial View of the East Slope of the Front Range..... vi

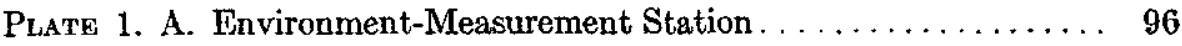

B. Montane Landscape...................... 96

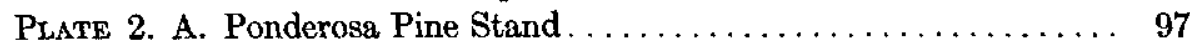

B. Douglasfir-Ponderosa Pine Stand ............. 97

Plate 3. A. Aspen Stand . . . . . . . . . . . . . . . . . . . . 98

B. Spruce-Fir Stand ...................... 98

Prate 4. Patterned Ground in Alpine Tundra on Niwot Ridge....... 99

Plate 5. A. Kobresia Meadow Stand in Early Fall............. 100

B. Kobresia Meadow Stand in Winter.............. 100 


\section{LIST OF TABLES}

1. Regional Ecosystems on the East Slope of the Front Range...... 24

2. Lower Montane Soils Data ....................... 26

3. A-1 Ponderosa Pine Stand Vegetation Data.............. 30

4. A-3 Ponderosa Pine Stand Vegetation Data.............. 32

5. Comparison of Four Stands in the Lower Montane Climax Region. . 34

6. A-2 Douglasfir-Ponderosa Pine Stand Vegetation Data.......... 36

7. Upper Montane Soils Data ...................... 40

8. B-1 Douglasfir-Ponderosa Pine Stand Vegetation Data ......... 43

9. Comparison of Four Climax Regions................. 45

10. B-2 Douglasfir-Ponderosa Pine Stand Vegetation Data........ 46

11. Comparison of Four Stands in the Upper Montane Climax Region. . 47

12. B-3 Ponderosa Pine-Douglasfir Stand Vegetation Data......... 49

13. Subalpine Soils Data.......................... 54

14. Silver Lake Spruce-Fir Stand Vegetation Data. . . . . . . . . . . 58

15. C-1C Lodgepole Pine Stand Vegetation Data .............. 60

16. C-3A Lodgepole Pine Stand Vegetation Data ............... 62

17. Comparison of Stands in the Subalpine Climax Region......... 63

18. C-2A Lodgepole Pine Stand Vegetation Data.............. 64

19. C-1D Aspen Stand Vegetation Data . . . . . . . . . . . . . . 68

20. C-3B Aspen Stand Vegetation Data.................. 70

21. C-2B Aspen Stand Vegetation Data .................. 71

22. C-1A Limber Pine Stand Vegetation Data................ 72

23. C-1B Limber Pine Stand Vegetation Data............... 73

24. Alpine Soils Data........................... 78

25. D-1A Kobresia Meadow Stand Vegetation Data............. 85

26. D-2A Kobresia Meadow Stand Vegetation Data............. 87

27. Comparison of Four Stands in the Alpine Climax Region ........ 88

28. D-1B Parry's Clover Stand Vegetation Data................ 90

29. D-3A Adoneus Buttercup Stand Vegetation Data............. 91

30. D-1C Cushion Plant Stand Vegetation Data.............. 93

LIST OF FIGURES

1. East Slope of the Front Range in Boulder County, Colorado...... 2 


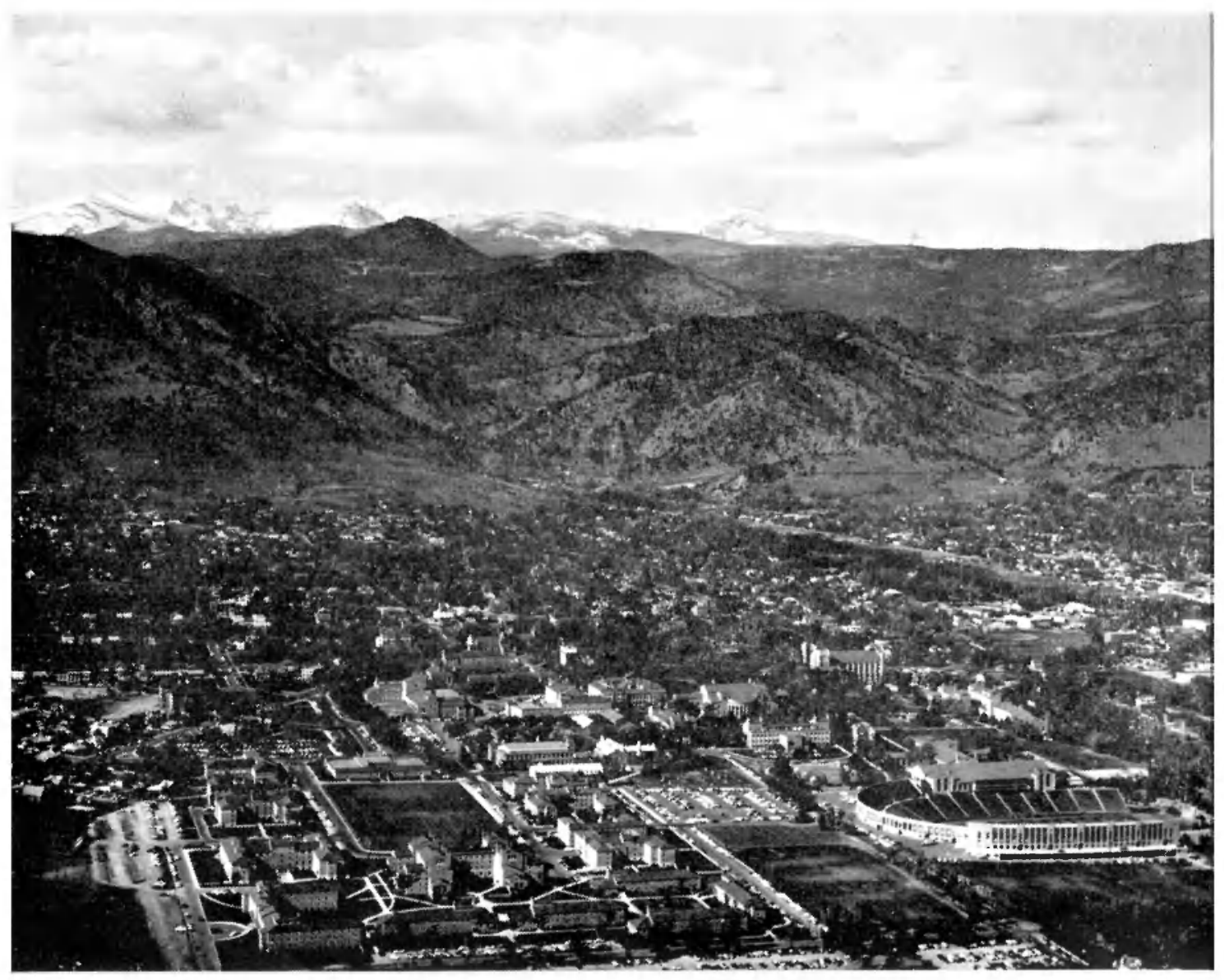

Pholograph by Floyd II alters

Aerial view of the east slope of the Front Range and the University of Colorado campus in Boulder. Natural vegetation of campus is grassland. Snow-covered landscape is mostly above upper treelimit. 


\section{ECOSYSTEMS OF THE EAST SLOPE OF THE FRONT RANGE IN COLORADO}

\section{INTRODUCTION}

A distant summer view of the East Slope of the Front Range in northern Colorado shows a dark band of coniferous forest limited by lighter-colored landscapes of grassland below and tundraland above (Fig. 1 and Frontispiece). Each of the three contrasting areas appears to be homogeneous, and the borders between them appear sharp. A closer view, however, reveals great diversity within each area and borders that are poorly defined. Herbaceous communities and stands of deciduous aspen trees occur scattered through the prevailing evergreen forest, and the species of dominant evergreen changes from one site to another; fingers of forest and isolated stands of trees penetrate the tundra and grass landscapes for varying distances and become progressively less common until they disappear entirely. This landscape, then, actually is broken up into a myriad of small units, most of which are repeated from place to place in an intricate, changing pattern, and the major areas gradually merge into one another. Description and explanation of this landscape pattern, processes which require identification, characterization and classification of the units which make it up, present a challenge to ecologists.

Partial explanation for the diversity of this landscape is evident after only brief acquaintance. It is general knowledge that mountain slopes rising a mile in altitude intersect different types of climate. Along one contour at any given altitude many features cause diversity: changes in topography produce differences in exposure to sun and wind; variations in soil parent material and topographic situation result in differences in texture, depth, and water content of soils; fires have burned small and large areas, sometimes repeatedly; miners, lumbermen, even farmers, along with sheep and cattle, have left few square feet unmodified by their activities.

Adding details and quantitative features to this general picture of mountain ecology is a much more tedious process, and progress has been slow. Measurements of environment factors in the high mountains were made as early as 1874 by the U. S. Army Signal Corps on the top of Pike's Peak. In the early part of this century, while ecology was just taking form in America, many of the young ecologists were attracted to the Front Range. C. S. Crandall published an analysis of lodgepole pine succession in 1897; William S. Cooper began his pioneer work on alpine ecology in 1904; Robert T. Young measured temperature and humidity for brief intervals at Boulder and at timberline on Arapahoe Peak in 1905; F. E. Clements applied his dynamic 


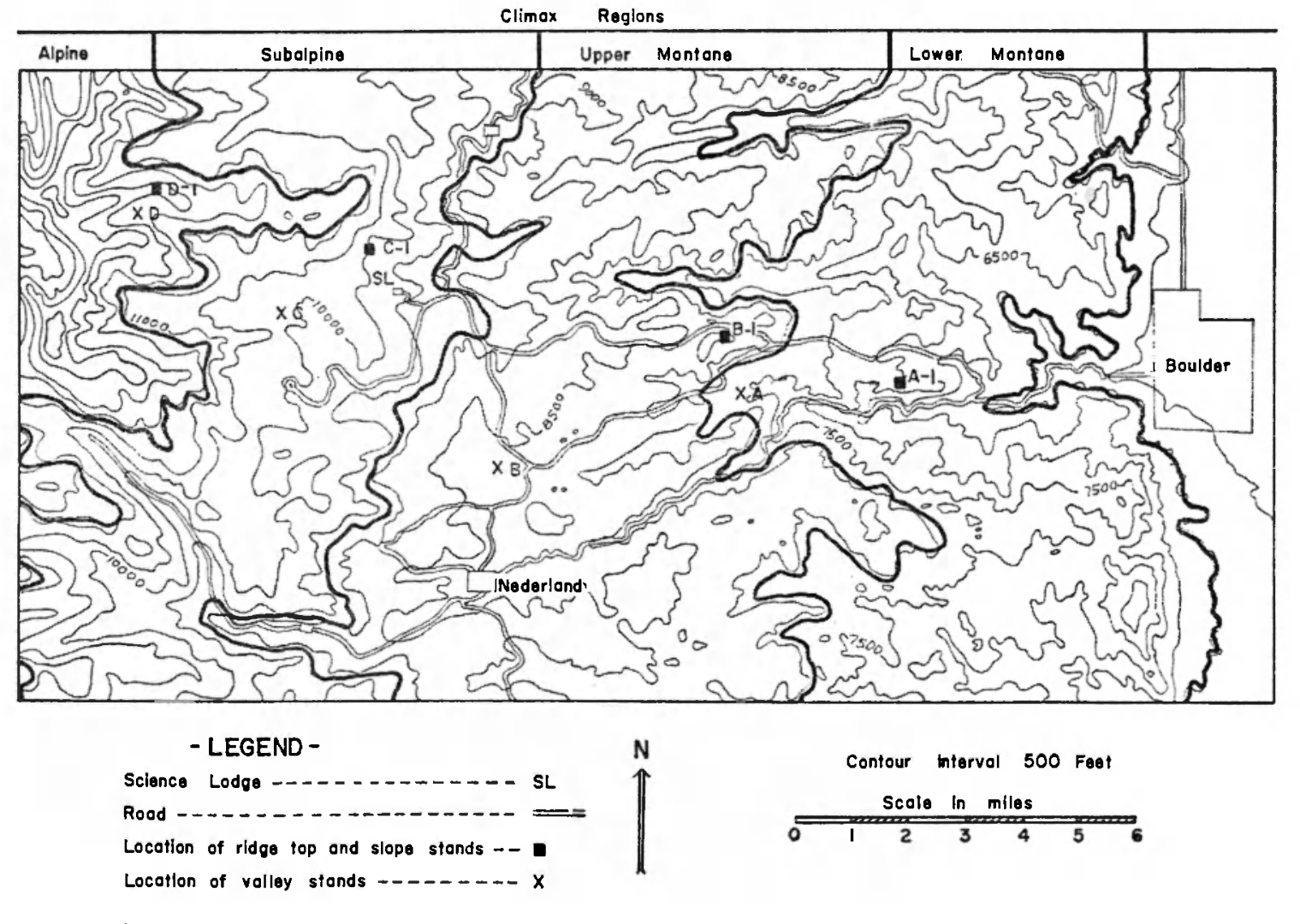


concepts to study of lodgepole pine succession after fires in 1910; Francis Ramaley published landscape classifications, mcasured environment factors (as early as 1910), studied a variety of community types, and stimulated and supervised many graduate students in field ecology; A. G. Vestal classified the vegetation of the lower mountains; C. J. Whitfield (1933), Clements and Goldsmith (1924) and others did research along an altitudinal transect from plains to tundra on Pikes Peak with the support of the Carnegie Institution of Washington. Publications by Ramaley (1927), Weaver and Clements (1938), and by Daubenmire (1943), summarized the ecological knowledge of the Rocky Mountains, and much that they contain applies to the east slope of the Front Range.

When I first began research on the terrestrial plant ecology of the Front Range in 1944, a review of the status of knowledge of its ecology indicated that there was disagreement on the most natural basis for subdividing the landscape into ecological units; there was a scarcity of quantilative data on vegetation and environment, and very little was known about the winter ecology of the area. I also discovered that working on these features, cspecially in the higher regions, would require special travel, living and research techniques, as well as considerable funds, timo, materiel, field facilities and personnel. However, further investigation suggested that all of the prerequisites for research in the mountains could eventually be met through the University of Colorado. Consequently I began research on a system of ccological units, quantitative measurements of environment factors, and "year-round" ecology of the Front Range.

Week-end field trips each month of the academic ycar were started in 1946 with the Biology Department's "Winter Research Class". Plans for field projects were developed, field-tested, and revised periodically; Science Lodge (Fig. 1), the Lniversity's center for summer field classes, was gradually modified into a year-round research station. The University established the Institute of Arctic and Alpine Research to give added impetus and coherence to the mountain program.

The first large-seale project for intensive studies was developed under a contract with the Office of the Quartermaster General in 1951. Precise numerical measurements of several environment factors and of vegetation in 16 sites were carried out under that project from 1951 to 1953. An ecological classification of the Front Range's landscape units based on the ecosystem concept was prepared during 1953 and 1954 as I organized the collected information and data into a report on the QM project (1956). Environment measurements at the four key ridgetop sites have been continued without serious interruption to the present time, and the Institute plans to carry this 
activity on indefinitely. Several detailed studies of selected ecosystems have been completed (Luti, 1953; Douglass, 1954; Johnson, 1956; Osburn, 1958; and Hess, 1959) and others are currently in progress.

The purpose of the present paper is to present (1) a classification of terrestrial ecological units of the Front Range based on the ecosystem concept, with vegetation as the indicator of the extent of each unit, (2) general descriptions of the vegetation and environment of the most common types of ecosystems, (3) quantitative data on the vegetation and environment of selected ecosystems and, (4) analysis of the successional status of many of the ecosystems. I have attempted to present the materials so that they will provide (1) an introduction to the plant ecology of the Front Range for students and other persons who visit the mountains, (2) a skeleton framework into which both plant and animal ecologists can fit their specialized studies in such a way that the entire ecology of the Range can be synthesized eventually into a single unified story, and (3) a modern treatment of the Range's plant ecology for the use of biologists generally.

Many persons and agencies made significant contributions to this project. The first and highest tribute goes to a group of young scientists who, as research assistants, carried the brunt of the field observation program that required of them exacting and fatiguing work under conditions that were far from ideal for scientific work, and not infrequently were fraught with some physical danger. Their work frequently called for exceptional physical stamina and always demanded accuracy and a delicate touch with sensitive instruments. Their ingenuity was taxed to the utmost in devising guards against malfunctioning of men under strain and fatigue, and of instruments and vehicles that were sometimes poorly designed for the environment in which we were using them. We originally had 16 environment-measurement stations containing, in all, a total of about 240 instruments that had to be serviced weekly or bi-weekly. It is a tribute to the abilities and stamina of these research assistants that, during the year of continuous observations, there was not one significant gap in the records. They contributed many ideas for procedures and methods that assured this continuity of records. It is a pleasure to express satisfaction, admiration, and appreciation for the work of these research assistants: Victor E. Favier, Albert W. Johnson, William S. Osburn, Markley W. Paddock, and William H. Rickard. Owen Albert Knorr, Ricardo Luti, and Hal Mooney made important contributions as research assistants in the summer of 1953. Many other students served in the important capacity of field assistants. Dr. William A. Weber's generous help in naming plants provided us with authoritative identifications. I am grateful to the following colleagues for criticism of the manuscript: William C. Bradley, Robert L. 
Crocker, Owen A. Knorr, William S. Osburn, Markley W. Paddock, Hugo G. Rodeck, Leslie A. Viereck, William A. Weber, and Olwen Williams.

The field research was made possible by the support of the Office of the Quartermaster General and Quartermaster Research and Development Command, United States Army, through a research contract. Personnel of the Quartermaster Corps, especially Lt. Colonel Albert H. Jackman, Mr. Francis Ramaley, Jr., and Mr. Will F. Thompson, gave helpful advice, made arrangements for loan of U. S. Government equipment and instruments, and handled administrative details. Without the support of the administrators and mechanics from the Pueblo Ordnance Depot, U. S. Army, the program could not have been carried out. The City of Boulder co-operated by permitting us to operate stations in the city watershed and to use the watershed roads for access to the tundra.

Several departments of the University were helpful in organizing, equipping, and operating the project. The Department of Biology granted me parttime leave from teaching, provided office space, and loaned certain instruments and materials. The Council for the Institute allocated funds from its own reserves in order to permit completion of the project. Final field work and extensive revisions of the manuscript for publication were accomplished as part of a project supported by the U. S. Atomic Energy Commission (Contract No. AT (11-1)-435) and, in part, while I was on a half-time Faculty Fellowship for one semester granted by the University's Council on Research and Creative Work.

It is a pleasure to express gratitude for all these contributions to the production of this paper. 


\section{THF UNIT OF STUDY AND ITS CHARACTERISTICS}

After experimenting with the use of various concepts, terms, and units, I concluded in 1954 that the ecosystem concept provides the most logical foundation for research and teaching in ecology. This concept has always been inherent in dynamic ecology, although general use of the term itself is quite recent. Cowles employed the concept in his physiographic ecology (1901), as did Cooper in his classical paper, "The Fundamentals of Vegetational Change", published in 1926. As Cooper states, "Organisms and environment make a system; events concerned with one necessarily involve both."

The first precise exposition of the ecosystem concept in the English language was published in 1935 by Professor A. G. Tansley, who writes as follows:

... the ... fundamental conception is as it seems to me, the whole system (in the sense of physics), including not only the organism-complex, but also the whole complex of physical factors forming what we call the environment of the biome - the habitat factors in the widest sense. Though the organisms may claim our primary interest, when we are trying to think fundamentally we cannot separate them from their special environment, with which they form one physical system.

It is the systems so formed which, from the point of view of the ecologist, are the basic units of nature on the face of the earth. Our natural human prejudices force us to consider the organisms (in the sense of the biologist) as the most important parts of these systems, but certainly the inorganic "factors" are also parts - there could be no system without them, and there is constant interchange of the most various kinds within each system, not only between the organisms but between the organic and the inorganic. These ecosystems, as we may call them, are of the most various kinds and sizes.

Major (1951), Daubenmire (1952), Costin (1954), Odum and Odum (1955), and others used the ecosystem concept in their research. Its use in teaching has been urged and described by Evans (1956), Odum (1957), and Sjörs (1955). I have used it now for eight years in both research and teaching and have found that it is efficient because it fits natural landscapes closely, requires a minimum of vocabulary, and is effective in the analysis and discussion of most of the basic principles and problems of ecology. I have developed the following description to explain how I use this concept:

An ecosystem is an ecological unit, a subdivision of the landscape, a geographic area that is relatively homogeneous and reasonably distinct from adjacent areas. It is made up of three groups of components - organisms, environment factors, and ecological processes. The organism category includes both plants and animals. Environment factor is used here in the broad sense of almost any physical substance, force, or condition; time, latitude, altitude, fire, and exposure, for example, are environment-factors along with soil mois- 
ture, air temperature, and so on. The ecological processes are interactions between organisms, between environment factors, and between organisms and environment factors.

Since ecosystem is a category of things, and the term can be applied to areas of any size, such as a small meadow or the extensive grasslands of Central North America, a classification of ecosystems is essential. As the literature, however, contained no classification of ecosystems, I developed one, keeping the obvious pitfalls in mind and using established ecological terms where they could apply. This classification is as simple as the need permits and will require elaboration as individual units are worked on more intensively and larger regions are encompassed. The four units used in the present study are the ecosystems that $I$ have named stand, stand-type, climax region, and ecotone region.

A stand is a concrete unit that can be mapped and studied in detail in the field; for example, the spruce-fir forest east of Silver Lake in Boulder County is a stand. Stands are divided into two major categories on the basis of their relative constancy in all characteristics. If some or all of their characteristics are changing, because their ecological processes are far from being in equilibrium, they are relatively transitory units and are called successional stands. When there is little change in the stand's total character from century to century, because the ecological processes are close to being in equilibrium, and there is no evidence in the region, nor in the publications on similar types of ecosystems in other regions, that it will change to another type under current climate and physiography, it is called a climax stand. There are usually a few to many different kinds of climax stands (real or potential) in any one climatic region, each climax being peculiar to that region. Each climax stand is under the predominant control of some major complex of environment factors, such as climate, soil, or topography. Several different systems of terminology have been developed for naming these stable units (and also the unstable ones related to them) (Oosting, 1956). Tansley (1935), whom I follow, as does Daubenmire (1952), in his paper on the northern Rockies, applied climax to every relatively stable unit regardless of the ultimate dominant control. Thus I use names like topographic climax and edaphic climax. A more detailed discussion of the characteristics of successional and climax units will be given below after the other ecosystem units have been introduced.

A stand-type is a synthetic unit whose characteristics are obtained by combining the range of variations between all the stands that resemble one another closely. The spruce-fir stand-type of the Front Range is a synthesis of all the stands of spruce-fir forest that resemble one another more than they resemble 
other stands. The successional and climax terms described above are applied to stand-types as well as to stands.

A climax region is an extensive geographic region within which there is a distinctive pattern (either real or potential) of climax stand-types; for simplicity, the region is often identified and described by its climatic climax alone, with the understanding, however, that many other stand-types, both climax and successional, are also present in the region. The portion of the Front Range that has a climatic climax of Engelmann spruce and subalpine fir is the subalpine forest climax region.

The boundary of a given stand ecosystem is of ten vague, because the components of adjacent stands tend to mingle with one another in a transition of variable width. Similarly, climax regions are not sharply set apart; between any two climax regions there is a relatively narrow area made up of a distinctive set of stands, possibly including some from the two adjacent climax regions; this area is an ecotone region, a landscape unit of equivalent rank with climax region. The "timberline area" or "tree-limit" is one such ecotone region. There are characteristic stands and stand-types in each ecotone region, but they are not deseribed in this paper.

Some confusion may be eliminated by a brief discussion of synonymy at this point:

The term stand is often used, especially by foresters, to designate only the vegetation portion of an ecosystem, using site for the stand's environment. I $\mathrm{am}$, therefore, using the term sland in a spccial sense that differs from some past usagc. I believe, however, that most people are thinking about both environment and vegetation when they use the term stand, and I think it preferable to modify the definition, restrieting thereby the usage of an old term, rather than to coin a new one at this time. Stand-type is approximately equivalent to Clement's faciation, and to association as used by Tansley and many other botanists. Climax region is comparable to Clement's association, and to life zone as used by Ramaley, Daubenmire, and others. Vegetation is all of the plants of an ecosystem of any given rank and their organization in the unit. Plant community is synonymous with vegetation as applied to units of any rank. Site is the same as external stand environment (see below).

Enviromment is a concept that is easy to describe in general terms but difficult to identify in the field, especially when one sets out to measure quantitative features of the environment's factors and is selecting the precise position in which to place an instrument. It is self-evident that the environment varies from place to place inside a stand, is different inside and outside of a stand, and changes from one stand-type to another. Platt (1958) has discussed this variability and the associated problems of measurement and correlation (1958) and has also proposed a simple classification of environments (1954). 
I have developed the following classification of environments: External stand environment means the environment in an area just outside the space within which the plants of a stand are interacting with environment factors impinging on the stand from outside sources. It is essentially synonymous with site and is a constant during one climatis interval, persisting unchanged even when vegetation changes. Internal stand environment means the environment inside a stand; its factors usually differ from those of the external stand environment as a result of interactions with other ecosystem components in the stand, but it is theoretically possible for certain factors to be the same in both environments. Most stands have a structure or organization produced by differences in the vertical or horizontal size or grouping of individual plants. These subdivisions of stands may be referred to as unions, layers, synusiac, or patches. In some types of research it is desirable to divide the internal stand environment into units that parallel one or more of these subdivisions of the stand and to study, for example, union environments. $\Lambda$ climax region environment is the external stand environment of the climatic-climax stand-type of that region.

The basis for separating stands into successional and climax categories was described briefly above. Since the terms succession and climax have been used in a variety of senses (Whittaker, 1953, and Churchill and Hanson, 1958), further clarification is desirable. An exhaustive discussion of these terms is not essential here, but it is desirable that their meaning as applied to stand ecosystems be made clear.

'The two terms can be understood more easily if a distinction is first made between two very distinct categories of ecosystem processes. First, there are processes of interactions between the components of a single stand, which operate within both successional and elimax stands and continue as long as the stand exists. Second, there is the process of change from one stand-type to another, which occurs only in successional stands and results from the processes of the first category. Additional comments on these processes are given in the following discussion of terms.

The words equilibrium and stability are frequently used in discussion of succession and climax and therefore require some attention here. It is relatively easy to see that a successional stand is unstable, that it is not in equilibrium. This use of these words does not cause much trouble. However, when one makes the oft-repeated statement that a climax stand is stable or is in equilibrium, many biologists rebel. Now, it certainly is true that no stand is "stable" or in "equilibrium" if the meaning intended is that the ecosystem processes have ceased; but this is not what is meant. All stands are dynamic internally; there are a myriad of processes going on in every stand as long as it exists; if they should cease, the stand would disintegrate. This fact is true of a climax as well as of a successional stand. The point of difference is that the 
internal dynamies in a climax stand are approximately in equilibrium while in a successional stand they are far from being in equilibrium. The basic difference between the two types is that successional stands possess an additional kind of dynamics: they are dynamic in total character, slowly changing from one stand-type to another, whereas the total character of a climax stand changes little from century to century.

Or to put it another way: In a climax stand the processes fluctuate within a range of variation that remains constant, while in a successional stand the range of variation of the processes is shifting in one direction. For example, in a spruce-fir climax stand, a blueberry shrub may grow up on the spot left bare when a 500-year-old spruce tree blew over, and a fir seedling may develop eventually under the blueberry and grow into a tree that eliminates the blueberry. However, no ponderosa pine or grama grass will ever occupy that spot (unless there is a drastic change in climate). In a successional aspen stand, on the other hand, spruce and fir trees grow up beside aspen trees and eventually replace them entirely, so that a spruce-fir stand occupies the site that supported an aspen stand at an earlier date.

One final comment on processes and stands: There are universal tendencies for ecological processes to bring about changes from one type of successional stand to another until a climax is reached (Cooper, 1926) and to maintain a climax stand in a relatively stable condition once it is established. To state these principles in greater detail, there is a progressive increase in the stability of successional stands that succeed one another in time in one site, because there is a decrease in both the kinds and the magnitudes of changes. Eventually a stand develops in which the many ecosystem processes are close to being in balance, and the stand is changing very slowly; study of neighboring stands and the literature on similar stands suggests that there will be little further change in the total character of the stand as long as climate and physiographic processes fluctuate within their current limits of variation. The same species of plants will have dominated the stand for a period of time that is long in comparison with the average life span of single individuals of those species (Beadle and Costin, 1952). This relatively stable stand is the climax. The climax is not a static entity, but rather, as Cowles put it: "... the condition of equilibrium is never reached, and when we say that there is an approach to the mesophytic forest, we speak only roughly and approximately. As a matter of fact we have a variable approaching a variable rather than a constant" (1901). Furthermore, as was mentioned above, it must not be implied that all ecosystem processes have slowed down or stopped. Most processes are continuing but the resultant of all processes is close to being an equilibrium. It is important to remember that the status of a stand is determined by all of its characteristics 
- for example, a stand is successional if it is changing in structure even though it already contains all of the species of the climax stand-type of that site.

The nature of a given elimax is determined by all of its components; the environment is holocoenotic (Cain, 1944), and no one factor changes without influencing other factors. The flora and fauna must also be considered in searching for the control of the character of a climax (Beadle, 1951). However, it is true that some complex of ecosystem components is usually paramount in controlling the character of a climax in any one climax region.

When all factors are operating at moderate or intermediate intensities, such as on a gently rolling surface with parent material of intermediate physical properties, and there has been ample time for the genesis of a deep soil whose properties are changing very slowly, and for experiments in ecesis (migration and establishment) by all species in the regional biota, and for a general balance to develop between species, the unit is a climatic climax (essentially the same as used by Daubenmire (1952)). The regional climate is the paramount control of the climatic climax. When some complex of ecosystem components deviates from the moderate magnitude, the climax will differ from the climatic climax and is named for the complex that prevents it from changing to the climatic climax. Thus when a slope is steep, topography is extreme and a relatively stable unit in such a site is a topographic climax. If topography is made more moderate, as it may be in geologic time, ecosystem change will tend to produce the climatic climax. Where soil parent material is of a type that results in a soil unusually coarse or fine, or one that has a deficiency or an excess of some mineral usually present in soil, the relatively stable unit is an edaphic climax. Fffects of both topography and soil are often so strong or so intermingled that they cannot be separated, resulting in a topocdaphic climax. Unusual concentrations of animals, or of plant or animal parasites, may produce a biotic climax.

There is a tendency for all succession in a given type of site to converge toward a given type of climax regardless of the differences that may exist between the successional stands of different sites of that type. Aspen may pioneer in one spruce-fir site and lodgepole pine in another spruce-fir site after lumbering; the product of succession in both sites, however, will be spruce-fir stands of one type. This fact means that there are tendencies for a particular characteristic pattern of climax stands to develop in each climax region, and that pattern tends to persist once it has developed. If processes of geologic planation and soil genesis proceeded more rapidly than organic evolution, and climate remained relatively constant, there would be a tendency for convergence of all climax stand-types of a given region to the region's climatic climax. 


\section{THE PROGRAM OF IN'THNSIVE FIELD STUDIES}

\section{A. Sflfation of Stands}

The project objectives, as listed above, required study of selected stands, with emphasis on measurement of environment, and observation of winter processes. The first step in designing the field program was to decide which of the innumerable stands should be studied. It had been recognized as early as 1907 that there were 4 different regions in this area (Ramaley, 1907) namely, Lower Montane, Upper Montane, Subalpine, and Alpine - and it was reasonable to expect that there would be at least 4 climax stand-types in each region, one on each of the 4 major topographic sites of ridge top, northfacing slope, south-facing slope, and valley floor. Field reconnaissance supported this expectation in the 2 lower regions, but no consistent relation between vegetation and those 4 topographic sites was evident in the subalpine and alpine regions. However, I decided to keep topographic site constant anyway in the different regions while measuring other factors that were varying with time. In order to minimize differences between sites that result from being located in different storm tracks or some peculiar local feature of air-mass movement, it was necessary to find an altitudinal transect that followed one ridge system from the Plains to the Continental Divide. I selected the landscape between the drainages of North Boulder Creek and Left Hand Creek, because it fulfilled the topography requirements and our facilities and road systems made it possible for us to devclop an efficient logistic system for yearround field work in this area.

Principles of regional ecology suggested that there would be variation between stands of one stand-type at different elevations within one region; consequently, I selected stands that were intermediate in the alitudinal range of their type. I also attempted to choose stands with soils and topographic settings that were moderate for their type. I had not yet identified individual stands in the tundra when the time came to install environment-measurement stations. Consequently, I selected 4 areas that were comparable in setting to the stands in the other regions. Topographic and travel complications dictated selecting a tundra valley area several hundred feet lower, and a lower montane valley area several hundred feet higher, than was called for in the project design. The location of study areas, facilities, and travel routes are given on the map in Figure 1.

\section{B. Environment Measurements}

\section{STATUS OF KNOWLEI)(HE OF MOUNTAIN ENVIRONMENTS}

The intrinsic complexity and variability of mountain environments in both space and time are well known. Measurement of any one factor for a period 
long enough to provide significant data requires considerable time and energy in servicing the instrument, checking its accuracy at reasonable intervals, and summarizing and interpreting the data provided. Data for any period of less than a year are useless for most purposes. It is, therefore, essential that one study his objectives carefully and design his program with care before starting a project on mcasurement of environment factors.

Reasonable samples of regional characteristics of environment factors have been measured by the Weather Bureau and other agencies and individuals in most of the non-mountain areas of the world, but mountain area data of value to ecology are notoriously lacking (Baker, 1944). However, there are some data for Colorado's mountains. In fact, in 1890 the third longest record in the state was for the top of Pike's Peak at an elevation of over 14,000 feet, where the U. S. Army Signal Corps had pioneered high-altitude weather data collecting from 1874 to 1888 (Greely, 1891). Additional data have been gathered at various communities in the mountains over the years, but most of these records are fragmentary. Some records lack a few months' data every year or so, most stations were operated for only a few years, and a large number of stations were, or are, in specialized sites that do not give a usable notion of the regional environment (Baker, 1944, and Ives, 1938). Attempts to compare different areas are frustrated by the fact that records at the different stations do not encompass the same time interval; therefore, because of the often great variation in annual environment from year to year, no comparison is valid. Bates (1924) comments on this variability of factors in time and the necessity for use of identical periods in comparing two areas.

Ramaley and his colleagues performed environment studies (Ramaley, Dodds, and Robbins, 1908; Ramaley and Robbins, 1909) that were outstanding for their time. Young had made some short-term measurements even earlier (1907). Robbins in 1910 and again in 1917 made the first attempts to characterize the climate of each of Colorado's major floristic regions. Ramaley compared the climates of Boulder, Tolland, and Rollins Pass in 1919. Whitfield (1932 and 1933) described the vegetation types of the Pike's Peak region and some of their atmospheric factors, using data collected during two summers. Bates's studies, published in 1924, made in the south part of the Front Range, measured many factors in many stands for reasonable lengths of time. Holch and his associates (1941) measured atmospheric factors during one summer at three stations in Rocky Mountain National Park just 40 miles north of our area. Baker (1944) includes the east slope of the mountains in Colorado in his graphs of Weather Bureau data that illustrate variations in several factors with change in elevation on the different mountain systems of the Western United States. 


\section{FACTORS TO BE MEAstred}

Aftcr revicwing the status of our knowledge of mountain environments, I decided that the most valuable contribution we could make with the abilities, materiel, facilities, and funds available would be to measure external stand environment on a year-round basis, using identical instruments and procedures in the 16 different sites selected for study.

External stand environment should be measured, ideally, on towers above the vegetation and in excavations below the plant roots. Practically, it is reasonable for most purposes simply to reduce vegetation effect on the instruments to a minimum. Consequently, stations for forest stands were placed in clearings subjected to little shading, and anemometers were mounted above the general tree level. The next step was to decide which of the many factors and factor-complexes on which data were needed should be measured first. Since many factors vary widely from day to day, month to month, and year to year, and data on these highly variable factors for different stands cannot be compared unless they are taken simultaneously, the initial project was designed for continuous study of the most variable factors through one entire year of measurement. Study of relativcly time-constant factors was given a low priority, because this study could be made in smaller projects concentrated on a single stand as time permitted.

Environment-measurement stations were first installed in the summer of 1951 (Fig. 1 and Plate 1A). Continuous operation of all instruments except anemometers began on 1 October, 1951. During the following winter, all instruments, procedures, and personnel were given thorough ehecks for accuracy, efficiency, and suitability for operations in the rigorous mountain environment. Innumerable problems were encountered and solved. Some instruments and individuals were found inadequate. The 4-inch diameter, plastic rain gauges we started with were found to be too small for sampling heavy snow storms. Recording instruments at the higher elevations required "winterization" to prevent snow from blowing into the housing and producing several complications. Flies found these instrument housings congenial environments and made record sheets almost useless by peppering them with "fly specks". These are only a few of the many problems that we had to solve.

Standard 8-inch diameter rain gauges and 3-cup anemometers were installed in the summer of 1952. All instruments and procedures were operating satisfactorily by the beginning of the year of continuous measurements on 1 October, 1952.

\section{INSTRUMENTATION}

Instrumentation at each station was as follows:

1. A standard "cotton belt" Weather Bureau type instrument shelter with 
its floor approximately 4 feet above the soil level housed Weather Bureau type maximum and minimum thermometers, a Bourdon-tube thermograph, a hair hygrograph, or a hygrothermograph and a sling psychrometer. At ridge top and all tundra stations, duplicate thermographs were operated as a precaution against loss of data due to instrument failure.

2. A standard 8-inch metal rain gauge with the top about 3 feet above the ground.

3. A metal soil-temperature box with Weather Bureau type maximum and minimum thermometers housed in metal pipes at depths between 5 and 7 inches and between 11 and 13 inches below the soil surface. The boxes are waterproof and have insulation in the lid and between the box and pipes. The soil was removed at the time of installation and packed lightly back into place after the pipes for holding thermometers had been installed. Plants were removed from the soil above the pipes as fast as they developed there.

4. A 3-cup totalizing anemometer, mounted in the top of a tree approximately 2 feet above the general level of tree crowns in forested areas, and approximately 8 feet above the soil in tundra sites.

5. Two sets of wooden poles for measuring snow depth, one anchored in the soil for readings on total depth, another mounted on cross-arms and placed on top of the snow surface each week to give weekly accumulation readings. These poles were placed in situations among trees where wind would not produce drifts. No quantitative records were made for stations in extensive clearings and above timberline where snow depth was controlled largely by wind.

Data were collected on certain environment characteristics not measured by the instruments listed above. Each week, depth of snow over the soil thermometers and the type and extent of cloud cover, if any, were recorded by station "servicers". At the end of each month, determinations were made of the water content of the snow pack and of the soil at depths of 5 to 7 and 11 to 13 inches.

Soil samples, exclusive of stones, were collected in each stand from depths of 0 to 6 inches and 6 to 12 inches, and mechanical analyses were made according to standard U. S. Department of Agriculture procedures by the U. S. Army Engineers Waterways Experiment Station.

\section{METHODS AND PROCEDURES}

The environments in which we operated and the circumstances of servicing trips often imposed severe physical and mental strain on the men doing the servicing. Furthermore, the instruments employed were not designed for the type of environment encountered at many of the stations. It was necessary, therefore, to devise unusually detailed field methods and procedure in order to insure correct performance of both men and instruments. Many weeks of 
careful study were spent in preparation of the first set of procedures, which were restudied and improved weekly until almost completely fool-proof routines were developed.

Study of the performance of instruments at each station during the year of test operation revealed that weekly servicing supplied data with rcasonable margins of error. It was, therefore, not necessary to use the standard and expensive procedure of hourly or daily checks. However, as a reasonably economical safeguard, we did visit the more accessible stations twice each week in order to check on accuracy of instruments and to replace any found faulty.

Special procedures were developed for servicing instruments and maintaining records in order to insure accuracy of data. Methods were devised for cross-checking each week the data on one factor measured by different instruments at one station or similar instruments at adjacent stations.

Several months of experience were necessary before a "servicer" absorbed these procedures so completely that he rarely made a mistake or failed to take proper corrective actions regardless of the severity of the weather or the extent of his physical fatigue. This period of apprenticeship was lengthened, of course, by the fact that a "servicer" had opportunity to practice the procedures only once a week.

The circumstances described above that required development of special field procedures also called for special methods of handling ficld records after they had reached the laboratory. As soon as possible after records were collected, they were studied carefully and a "Status of Stations and Evaluation of Data" form was filled out. Instrument charts and field-data sheets were then microfilmed and the film stored in a fireproof vault as a precaution against loss of valuable records. Field data were transferred to "Summary of Environment" tables as rapidly as pressure of carrying on the more rigid requirements of field work permitted. Finally, several additional types of summaries, charts, and graphs were prepared in order to condense the original data to dimensions that could be easily grasped by a reader.

\section{PREPARATION OF SUMMARIES}

It was necessary to condense the large volume of raw field data in order to obtain figures that could be comprehended and compared with reasonable ease. The raw data for the one year of continuous observations consisted of approximately the following: 1,500 field-data sheets, 2,300 charts from recording instruments, 900 special observation sheets, and hundreds of supplementary observation sheets.

Data from each station were first evaluated carefully by using a variety of methods for checking the accuracy of instruments and servicers. Certain data 
were then transferred to the monthly summary sheets, and daily and monthly means and extremes were determined and recorded. The completed summary was redone by a different assistant to eliminate errors. The First Assistant then inspected the summaries by following a given factor through successive weeks and checking back to original data on any situations that appeared odd. Finally, I checked all summaries, employing a method of comparing summaries from adjacent stations that brought to light some errors and also provided information on numerous characteristics of the environment.

Annual summary sheets were prepared for each station (Appendix II); more-condensed tables were prepared for each region (Tables 5, 11, 17, and 27) and for the climatic-climax sites of each region (Table 9). The data have been used in the present paper to characterize the environments of many stands and of the four climax regions. A separate paper on more detailed analyses and comparisons of these data is under preparation.

I believe that data from our stations are comparable in terms of accuracy and of representation for an area with those collected by the U. S. Weather Bureau. For example, our D-1 Tundra Ridge Top Station data probably have a relation to actual regional conditions for that site that compares favorably with the relation of the Denver Weather Bureau data to the actual conditions in the Denver area. Since our stations are free of the effects of human cultural influence, they probably give data that are actually closer to the natural environment than are those of the Burcau. We recognize, nevertheless, the inadequacies of both sources of data.

\section{Study of Vegetation}

Quantitative data on the vegetation of the stands were collected in 1953 by the assistants, who used a quadrat method. Some of the stands were small and more heterogeneous than desirable, because, in selecting them, I gave priority to their appropriateness for the environment-measurement program. Consequently, quadrats were located so as to sample the range of variation in the stand. The following data on trees were collected in at least three square quadrats, $66 \times 66$ feet, in each stand: species and diameter of all trees, age and height of several individuals in each size class, and species (where possible) and diameter of all stumps. The presence and per cent cover of each shrub species and of saplings (over 1-inch diameter, breast height) of each tree species were recorded for square quadrats, $12 \times 12$ feet, nested in the northwest and southeast corners of each tree quadrat. Finally, the presence of each herb species and seedlings of each tree species were recorded in square quadrats, $3 \times 3$ feet, nested in each eorner of each trec quadrat. Since the 3 lower valley. floor stands were continually disturbed by man and/or stock, no quadrat 
samples were taken for them; instead, a complete list of species present was prepared for each stand.

The number of species present in each stand was often large. In order to keep the data in tables to reasonable dimensions, only those species having a presence of more than $20 \%$ were included. A complete list of all species observed in each stand is presented in Appendix I. Plant names were based on Weber, 1961.

The stands are named for the "conspicuous" plant(s); such species may or may not be the dominants in the sense of having the highest cover or basal area in the stand. 


\section{REGIONAI FEATURES OF THE FRONT RANGE}

Some of the conspicuous regional features of the Front Range were described in the introductory section. A few additional details that apply to the study area as a whole will now be reviewed.

\section{A. Geography and Geology}

The Front Range is unique geographically because it is the easternmost unit of the complex Rocky Mountain System; it is bounded by the Great Plains on the east, and by mountain ranges or large inter-mountain "parks" on the west; it merges almost imperceptibly into other mountain ranges to the north and south. The Continental Divide forms the backbone of the Front Range.

Many geomorphic processes have been active in developing the surface forms of the Front Range. There is no single dominant topographic form for the range as a whole; valleys vary from deep and narrow to shallow and broad; some interstream uplands are knife-edges while others are broad, gently rolling surfaces; there are some high peaks with broad, rounded tops while others are sharp, with only a few square yards on their top.

The east slope of the range rises from the 5,600-foot elevation of the Plains to peaks over 13,000 feet and passes that are rarely lower than 11,500 fect. This climb of more than a vertical mile in a horizontal distance of 20 miles occurs in 2 giant steps. Ridges rise to approximately 8,500 feet within 5 miles of the Plains and then climb very gently in an irregular, rolling surface, which some authors have called the Rocky Mountain surface (Plate 1B), for approximately 8 miles to an elevation of about 9,000 feet. Ridges then rise more steeply for 2 or 3 miles to another more level area, around 11,400 feet, that some geologists have called the Flattop surface. This latter surface, made up of gentle siopes and low knolls, rises slowly to the west for several miles, sometimes reaching almost to the Divide but more often terminating in a narrow, steep-sided ridgc.

Valley profiles are also irregular, but their steps do not coincide spatially with those of the ridges. Most valleys are narrow and deep near the foothills. They climb at a relatively gentle gradient for about 6 miles up to an elevation of around 6,000 feet. A steeper gradient, often marked by rapids in narrow, deep gorges, raises the profile to about 7,500 feet in a few miles where valleys become broader and have more gentle slopes. Thereafter, the rise is gentle up into the region that was glaciated in Pleistocene time, where valleys are often even more broad for some distance. Proceeding westward, all valleys eventually become narrow and deep again with profiles that, as a product of 
glaciation, are U-shaped in cross-section, and "giant-stepped" longitudinally. They terminate in deep, precipitous-walled, glacial cirques.

The country rocks are Precambrian granites to granodiorites and metamorphics in large batholithic masses, and Tertiary quartz monzonites to diorites that occur in part as stocks, dikes, and sills injected into the Precambrian rocks. Sedimentary rocks of Paleozoic and Mesozoic age are confined to the foothills area. A complex pattern of faults has affected the topography in many parts of the Range. Glaciers have produced spectacular landscapes in the higher areas and have influenced topography down to about 8,000 feet.

\section{B. Climate and Weather}

The climate of the entire study area is continental in general character; sudden and extreme changes in atmospheric factors may occur from hour to hour, day to day, any season of the year, and from year to year. Robbins (1910 and 1917) summarized the available climatic data for the Front Range in his reviews of the climate of Colorado. The general character of the climate is described in Daubenmire's 1943 paper, and Ives (1938) gives details on many features of the Front Range weather.

The east slope is on the lee side of the range with respect to the prevailing westerly winds. Air masses move in from the north, northwest, west, southwest, and southeast from time to time, each producing a characteristic type of weather. Cold fronts from the north, any season of the year, often move southward parallel to the mountains, forming stratus clouds at the base of the warm air they are forcing upward, and pouring cold air back into the mountain valleys. The regional consequence is a strong temperature inversion with relatively warm, sunny weather above, and dark, colder weather below, the clouds for a few hours or days. The cold air eventually displaces the warm entirely, skies clear, and night temperatures drop to their lowest point. There follows a period of several days during which strong solar radiation warms the ground, which in turn radiates back to the atmosphere, and there is a general rise in regional temperature until the maximum possible under existing radiation and air-mass conditions is reached. Thereafter, the weather remains relatively stable until upset by the appearance of another air mass or, in summer, by a build-up of convectional activity. These cold-front storms sometimes produce significant amounts of precipitation, especially when there is a continued influx of warm Gulf air above the cold mass. However, many cold fronts move through so rapidly that little or no precipitation occurs.

Pacific air masses enter Colorado from any westerly direction but most 
commonly come from almost due west. They are notorious for producing strong winds. Under certain meteorological conditions, these west winds produce a chinook wind (Cook and Topil, 1952) which is unseasonably warm and dry, especially at lower elevations, and has peculiar and disquieting psychological effects on human beings. The familiar giant "crest-cloud" (Ives 1950) often forms along the crest of the Divide during a chinook. These westerly winds contribute some precipitation at higher elevations but the amount is insignificant below 9,000 feet and of limited volume above that elevation.

Gulf air masses, often modified by mixture with air from other sources, move into Colorado most vigorously in spring and fall; as they rise along the mountain slopes, or are elevated by a cold front, they give rise to the major portion of the east slope's precipitation. Many of these storms dissipate at an elevation of about 9,000 feet, but each season some of them reach to the Divide, with the deepest snowfall occurring most frequently in the subalpine. Occasionally, one of these warm-front storms becomes spectacular by dumping a deep snow cover over the entire east slope, as much as 3 feet deep in the foothills and over a foot deep at 12,000 feet.

Summer convectional storms, the familiar "mountain thunderstorms", produce an abundance of precipitation, and their lightning sometimes destroys trees and, less frequently, starts fires.

Fire has always been an important component of the Front Range landscape. Crandall (1897), Clements (1910), Sperry (1936), and Stahelin (1943) describe many aspects of the ecology of fire in this area.

\section{'C. Vegetation}

The flora of the range is well known and is covered by the excellent books by Weber (1961) and by Harrington (1954). The general character of the more common vegetation types of the east slope are fairly well known, although their ecology has been somewhat confused. A review of the general features of the vegetation of the entire slope follows.

The conspicuous topographic break between the plains and the foothills of the Rocky Mountains is accompanied by an equally striking change in vegetation, from grassland to forest. 'The grasslands that dominate the Great Plains are broken by groves of trees only in isolated sites of unusual soil conditions and in strips along river valleys. Grasses also dominate many of the lower mesas and foothill slopes, but trees become dominant on the higher mesas and foothill slopes at the base of the mountains. The rocky backbone of the foothills usually is occupied by a band of ponderosa pine (Pinus ponderosa Laws.) trees, while grasses cover the deeper and finer soil in the low- 
lands between the hills. At progressively higher elcvations, between about 5,600 and 6,000 feet, grasses become less abundant, and trees become more common. Within this area, regional climate is suitable for both grasses and trees; differences in soil or topography, or both, determine which of the two vegetation types will occupy a given locality. Fine, deep soil supports grassland; coarse, rocky soil and even fractured rock outcrops support pine. Open stands of ponderosa pine on south-facing slopes are often park-like. Stands on north-facing slopes are more dense and may contain Douglasfir (Pseudotsuga menziesii (Mirbel) Franco), ponderosa pine, or a mixture of the two species. Cottonwood trees (Populus sargentii Dode) similar to those on river bottoms in the plains extend up into the mountains along rivers, but the species change with increase in altitude first to $P$. acuminata $\mathrm{Rydb}$. and then to $P$. angustifolia James.

Forest is the dominant vegetation from about 6,000 feet to treelimit at approximately 11,400 feet. Between elevations of approximately 6,000 and 7,700 feet, ponderosa pine and Douglasfir are the conspicuous trees, ponderosa pine being dominant on southern exposures and a mixture of ponderosa pine and Douglasfir dominating northern exposures. Extensive dry meadows are still common in this area, especially on south-facing slopes. Douglasfir becomes more and more common on southern exposures with increasing altitude. From elevations of about 8,000 to 9,000 feet, the same tree species are common, but individual communities have a greater density. Stands on southern exposures are dominated by a mixture of Douglasfir and ponderosa pine. Northern exposures may have a clear dominance of the Douglasfir, although ponderosa pine is rarely absent. Meadows are less frequent than at lower elevations.

Stands of lodgepole pine (Pinus contorta Dougl.) and aspen (Populus tremuloides Michx.) become common on north-facing slopes around 8,500 feet elevation and on ridge tops and south-facing slopes a few hundred fcet higher. These two species are the only trees over many acres of landscape affected by lumbering and/or fire. They occur above the upper altitudinal limits of ponderosa pine and Douglasfir but become less common above approximately 10,000 feet.

Engelmann spruce (Picea engelmannii (Parry) Engelm.) and subalpine fir (Abies lasiocarpa (Hook.) Nutt.), join the other trees around an elevation of 9,000 feet and are the most abundant species from about 10,000 feet up to about 11,000 feet.

Trees become progressively smaller and more deformed, and the smaller alpine-tundra plants become more abundant, between about 11,000 and 11,400 
feet in the fascinating "treelimit" region. Spruce, fir, and limber pine are the most common "trees", but there are occasional individuals of aspen and lodgepole pine in this ecotone region. Herbs, minute shrubs, and lichens are the dominant plants above 11,400 feet.

The last tree to be mentioned is limber pine (Pinus flexilis James), the species that has the widest altitudinal range. It is never abundant over a large area but does occur from around 8,000 feet to tree-limit, usually in sites that are windy and have coarse soil.

Ponderosa pine, Douglasfir, spruce, and fir are dominants in climax as well as in successional stands. Aspen is usually successional, but small, isolated stands may be climaxes. Lodgepole pine is always successional. Limber pine is usually climax but does form successional units in certain situations.

Most forest stands on the east slope of the Front Range have been affected by lumbering or fire or both. Papers describing succession after fire and disturbance by men are cited in the discussions of the individual stands in the next section. Successional processes in the absence of fire and man have been described by Cooper (1908), Schneider (1911), Ramaley (1916, 1919, 1920), Robbins (1918), Schwann \& Costello (1951), and Griggs (1956).

\section{Regional Ecosystems}

I referred in the introduction to the great variety of landscape units in the study area. Biologists have organized these units according to several different systems of classifications. The earliest Colorado biologists applied the Merriam system (1898) with varying degrees of satisfaction (Young, 1907; Cary, 1911); Niedrach and Rockwell (1939), Gregg (1947), Knorr (1959), and several other zoologists have used it in more recent publications. Few botanists, however, have ever made use of it. Gregg (1947) defended it, and Daubenmire (1938) was critical of it. Ramaley found it unsatisfactory for the Front Range and published his own in 1907, and made several revisions from time to time, the latest in 1927 . Other early efforts at classification were made by Robbins (1910) and Rydberg (1916). All of the foregoing classifications were based on floristics. Classifications employing the ecological concepts of succession and climax were made by Whitfield (1933), Weaver and Clements (1938), and finally by Daubenmire (1943). All of the classifications recognized at least three major regions, but the names, diagnostic characters, and geographic limits of the regions differed.

None of the systems thus far published has been based on ecosystem units. Consequently, I have developed the classification given in Table 1. It parallels Weaver and Clements (1938) and Daubenmire (1943) closely, but is more 
UNIVERSITY OF COLORADO STUDIES

TABLE 1. Regional Ecosystems on the East Slope of the Front Range

\begin{tabular}{l|c}
\hline \multicolumn{1}{c|}{ Ecosystems } & Altitudinal Extent in Feet on Broad \\
Ridge Tops*
\end{tabular}

- Ecosystem boundaries ure not shurp; consequently, these figures are only approximations.

detailed, is specifically designed for this local area, and employs different names for some units in order to achieve greater uniformity in terminology.

The different climax regions and their component stands are described in the following sections. The ecotone regions are not included because they have not been studied in detail. 


\section{THE CLIMAX REGIONS AND STANDS}

The 4 climax regions are treated separately in the following sections. Each section is divided into 2 parts, the first covering the regional features, and the second giving details on certain components of the common stand-types. The descriptive information is based largely on my own observations in the field during the past 17 years, although much of it can also be found scattered through earlier literature. Repetition of this basic information here is desirable in order that it be available in one publication and in the language of today's plant ecology. The environment data in the following sections were collected in the 1951-1952 program described in the foregoing sections. The map in Figure 1 gives the location of the climax regions and the stands that were studied intensively.

\section{A. The Lower Montane Forest Climax Regron}

\section{REgIONAL CHARACTERISTICS}

Geography and Geology: This ecosystem corresponds to that area which has been called the ponderosa pine zone, the ponderosa pine climax, and the foothills zone. On the east slope of the Front Range, it lies between the grassland region below and the upper montane region above at elevations, roughly, between 6,000 and 7,700 feet.

The lower montane is a region of rough mountains with deep, narrow valleys, narrow or broad-topped ridges, and slopes that vary from gentle to very steep (Plate 1B). Major streams occupy deeply incised meanders. Floodplains are often missing; if present, they are usually narrow, the stream often dropping rapidly in a boulder-strewn channel that may run beneath sheer cliffs or steep talus slopes. These valleys may be as deep as 1,000 feet. Larger streams carry water all year, but become mere trickles while water is being taken off in irrigation ditches. Many small intermittent streams carry water in the spring and early summer, but are dry in the fall and winter. The valleys of these small streams begin as broad basins, but they become narrow as they approach the Plains. Granites, granodiorites, schists, and gneisses of the bedrock are abundantly exposed in valley walls, cliffs, and rocky knobs on ridge tops. In the latter sites boulders may be as large as 30 feet in diameter, and they are usually rounded in the form common in this "montane" environment. The rocks of talus slopes are usually angular.

Soils: The term soil is used in this paper in the broadest possible sense to include all types of substrates, from rock surfaces to deep deposits of fragmontal inorganic and/or organic material; these substrates may or may not 
TABLE 2. Lower Montane Soils Data

\begin{tabular}{|c|c|c|c|c|c|c|}
\hline \multirow{3}{*}{ Stand } & \multirow{3}{*}{ Depth, inches } & \multirow{3}{*}{ Soil Type } & \multicolumn{4}{|c|}{ Mechanical Analysis: Particle Size in mm. } \\
\hline & & & \multirow{2}{*}{$\%$ over 2} & \multicolumn{3}{|c|}{ Percentages of Fraction under 2} \\
\hline & & & & $2-0.05$ & $0.05-0.002$ & $\begin{array}{l}\text { below } \\
0.002\end{array}$ \\
\hline \multirow[t]{2}{*}{ A-1 } & $0-6$ & Sandy loam & 21 & 71 & 17 & 13 \\
\hline & $6-12$ & Sandy loam & 16 & 66 & 16 & 18 \\
\hline \multirow[t]{2}{*}{$A-2$} & $0-6$ & Sandy loam & 25 & 77 & 13 & 9 \\
\hline & $6-12$ & Loamy sand & 30 & 80 & 10 & 10 \\
\hline \multirow[t]{2}{*}{ A-3 } & $0-6$ & Sandy loam & 19 & 73 & 16 & 11 \\
\hline & $6-12$ & Sandy loam & 23 & 77 & 14 & 9 \\
\hline \multirow[t]{2}{*}{$A-4$} & $0-6$ & Loamy sand & 11 & 80 & 12 & 8 \\
\hline & $6-12$ & Sandy loam & 9 & 78 & 13 & 9 \\
\hline
\end{tabular}

be differentiated into the horizons that characterize soils with mature profiles. Soils are highly variable but are usually coarse textured and shallow (Table 2). On ridges there is a gradation in soil from the abundant rocky knobs outward, and from the top of a ridge down the slopes. Adjacent to outcrops it is coarse and shallow; outward and down slope it becomes deeper and finer. Micro-terraces, only 3 to 6 inches wide, are produced by surface wash between the tufts of plants. It is possible that solifluction and needle-ice dynamics and grazing animals contribute to the production and maintenance of these terraces, especially on south-facing slopes.

Soil profiles are poorly developed on ridge tops and upper slopes. The deepest soil and best-developed profiles occur where small tributary valleys enter larger valleys. The parent material here has been transported by both water and gravity (slow creep), possibly accelerated in glacial times by soliffuction. Many profiles lack a conspicuous horizon of clay concentration (B horizon). The soils are sandy loams or loamy sands (Table 2) and are related to the grey-brown podzolic soils.

Soil water content is low most of the year, remaining close to the "wilting percentage" most of the fall and winter. Soil ice is rare, but it does occur at the surface for short intervals during the winter.

Climate: Many factors of the lower montane regional environment were measured at Station A-1 (see Appendix Table A). The climate is relatively warm and dry. Summers are relatively long and hot compared to those of higher regions. Summer precipitation, mostly in the form of mid-day thunder- 
storms, about equals that of the other regions but is less effective because of higher temperature. The autumn is cool with occasional wet snowstorms; a period of several weeks of dry, warm, calm "Indian Summer" weather is common. The dryness of the fall usually continues into early winter. Winters are generally cool, but are often just as cold as the other climax regions during periods of very low temperature. Snowstorms do occur, sometimes leaving over a foot of snow. Snow may remain on the ground in patches on northfacing slopes most of the winter, but it usually melts off south exposures within a few hours or days after each storm. Winter winds are sometimes very strong. In the spring there is an alternation of cool and warm intervals, and wet snow or rain storms are common.

The wind is prevailingly from the west at all seasons. Strong winds are always from the west; east winds are gentle and often supply considerable precipitation; the coldest winds are from the north. The warm, dry chinook wind from the west is common during the cold season.

Vegetation: Lumbering, fires, mining, and unsuccessful attempts at agriculture have disturbed this region so much that not a single acre has retained its primeval character. Consequently, areas of uniform vegetation are small, and stands of all ages, except maturity, are abundant. Johnson (1945) describes many effects of cultivation and grazing.

The lower montane vegetation consists of open forest of broad-crowned, evergreen trees frequently interrupted by grassy openings, and by extensive dry grassland stands. Ponderosa pine and Douglasfir, the dominant trees, are about 40 feet tall at maturity. Shrubs, herbs, and grasses are sparse under the trees and do not cover the ground between trees and in the grasslands. There are striking differences in the density of stands of different ages and on different exposures. Young stands may be very dense, but they always become more open as they mature. Mature stands on steep, north exposures usually have an almost closed canopy, while those on south exposures may be park-like in their openness.

A transect across a valley and around the east "end" of a ridge on a single contour reveals the following general pattern of ecosystems:

Ridgetops and gently rolling uplands are usually well forested with ponderosa pine, but small grassy openings are common. A few Douglasfirs grow with the pines, especially on the north half of the ridgetop. The forest becomes progressively more open down the south-facing slope of the valley. Where the slope is gentle, trees and grasses form a park-land on mid-slopes, and grasses become completely dominant on the lowermost slope where soil is relatively fine textured and deep. Where the slope is very steep, forest continues down to the valley floor, because the character of the bedrock and/or the angle of slope has prevented deep accumulation of finer soil. Rocky Moun- 
tain juniper (Juniperus virginiana L. var. scopulorum (Sarg.) Lemmon) is a common associate of the pine on these south-facing slopes.

Valley-floor vegetation varies with the width of the valley. Narrow floors support a dense mixture of lush grasses and herbs, low and tall shrubs (Salix irrorata Anders., Betula occidentalis Hook.), and any one or all of the local trees (cottonwood, willow (Salix amygdaloides Anders.), ponderosa pine, and Douglasfir). The familiar Colorado blue spruce (Picea pungens Engelm.) often occurs along the streams in both this region and the upper montane. Broad valley floors have deep soils and high water tables, and the plants become segregated into zones. Dense, wet meadows of grasses, sedges, and rushes (Juncus balticus Willd.) grow on the north side of the drainage channel and often lap over onto the other side. Shrubs are abundant along the channel and may form a continuous zone along the south side of the channel. Forest begins on the south edge of the valley floor; any of the tree species mentioned above may be present, and aspen occasionally grows with them.

North-facing slopes support a relatively dense forest of Douglasfir and ponderosa pine; the relative abundance of the two species varies with the angle of slope, Douglasfir increasing with increase in the angle. A high percentage of ponderosa pine may indicate the presence of coarser soil as well as a more gentle slope. Grassy openings are rare on north-facing slopes and indicate unusual soil conditions where they do occur.

The ridge tops in this area lose altitude toward the east. Around their eastern "ends", there is a striking change in ecosystems along a single contour. Rather dense forest of Douglasfir and ponderosa pine on the northfacing slopes begins to thin out as the exposure bccomes more easterly. Then Douglasfir drops out. Open forest of ponderosa pine prevails on the southfacing slope.

The foregoing review is based on the regional character of east-west trending ridges. Wherever ridge and valley deviate from that general orientation, the vegetation pattern varies in the direction easily predicted from the regional behavior of the species.

'Two tree parasites, Black Hills' beetle (Dendroctonus ponderosa Hook.) and mistletoc (Arceuthobium vaginatum Willd.) have damaged and often killed many ponderosa pine trees in both the upper and lower montane.

\section{THE MAJOR STAND-TYPES}

\section{a. Ponderosa Pine Stand Complex}

\section{(1) General Features}

There are innumerable stands in the Front Range in which ponderosa pine is the most conspicuous tree (Plate 2A). The ponderosa pine stands differ 
from one another in the relative importance of associated species, in the degree of dominance of the pine, in some environment features, and in their history, especially the length of time since the last disturbance. It is apparent, from relatively limited studies, that these stands represent more than one stand-type, but we do not have enough data now to make a stand-type classification. Consequently, these stands are lumped under the heading "stand complex" for the present.

Young ponderosa pine stands on more mesic sites are very dense, but trees die rapidly in the intense competition, so that stands over one hundred years old are quite open. On dry slopes, the stands of all ages are open, with a few shrubs (Ribes cereum Dougl.), a sparse ground cover of bunchgrasses (Hesperochloa kingii (Wats.) Rydb.), and a few herbs. In the typical old stand, tree crowns generally do not meet, and trees average 40 feet tall with some vigorous individuals reaching a height of 50 feet. The trees are often clumped in groups of a few individuals separated by openings with a sparse cover of herbs in a park-land type of landscape.

All but a very few of the present-day ponderosa pine stands are stages of secondary succession. The few climax stands that do occur are small and occupy extreme sites. There are many relatively mature stands on moderate sites, however, in which several characteristics of the potential climax are evident, and additional climax characteristics can be deduced by projecting current successional trends to their ultimate potential development. It is therefore possible, after extensive field work, to predict the character of the climax types with considerable accuracy; one can combine bits of information from the many current stands and synthesize a reasonably accurate description of the potential climax stands.

The ponderosa pine climatic-climax stand-type occurs on gently rolling surfaces with well-developed soil. It is an open stand with a few Ribes cereum shrubs and a sparse cover of herbs that leave much bare ground exposed to the atmosphere. A more open phase of this stand-type, with juniper fairly common and Bouteloua gracilis (H.B.K.) Lag. conspicuous, forms a topographic-climax stand-type on south-facing slopes.

\section{(2) Detailed Study Stands}

Stand A-1 is on the gently rolling crest of the ridge south of Bummer's Gulch (Figure 1). The ridge top is about 260 feet widc and lies at an clevation of about 7,000 feet. The stand resembles innumerable others of this type along the foothills of the Rockies. Trees grow both as isolated individuals and in clumps; piles of rounded granite boulders occur here and there, and patches of coarse, bare soil are common. The total area of tree trunks occupies only $0.1 \%$ of the 4,356 square feet area in 3 sample quadrats (Table 3 ). Trees 
Table 3. A-1 Ponderosa Pine Stand Vegetation Data

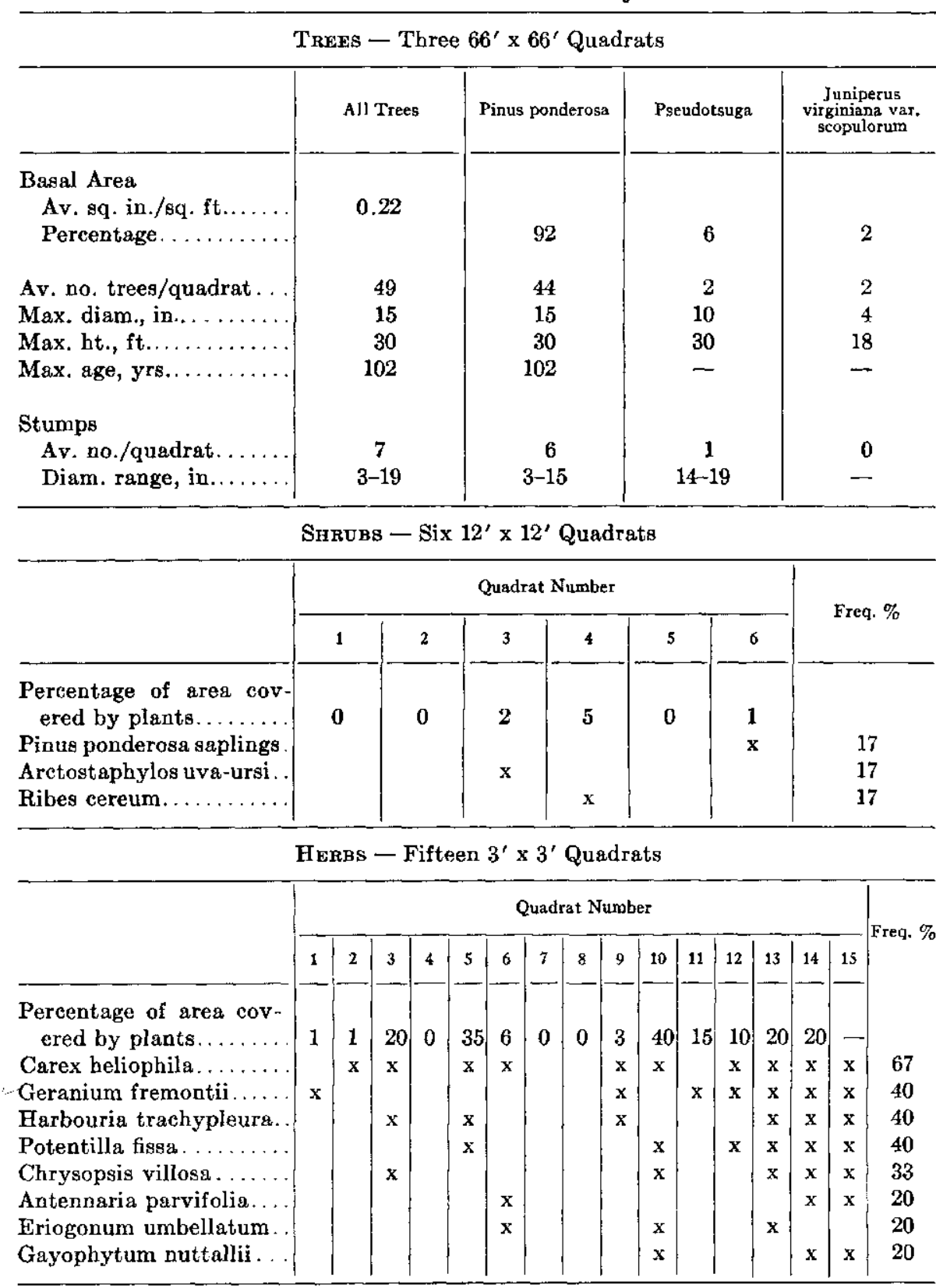

Note: Twenty-one other species present in the quadrats with a frequency of less than 20 per cent are listed in the species lint is Appendix I. 
are of all sizes from small saplings to individuals over 100 years old and 30 feet tall. There are a few Douglasfirs and Rocky Mountain junipers in the stand, mostly on the north side. Tree seedlings are predominantly ponderosa pine; the Douglasfir seedlings present are all on the north edge of the stand. One Ribes cereum and one Arctostaphylos uva-ursi (L.) Spreng., covering 7 and 3 square feet, respectively, were found in 612 -x-12-foot quadrats (Table $3)$. The total cover of herbs and the frequency of herb species are given in Table 3. The presence of a given species in a given quadrat is indicated by an " $x$ " in this table and subsequent ones of vegetation data. Carex heliophila Mack., Geranium fremontii Torr., Harbouria trachypleura (Gray) C. \& R., Potentilla fissa Nutt., and Chrysopsis villosa (Pursh) Nutt. are the dominant herbs.

The A-1 external stand environment was measured at a station located in a natural opening in the center of the stand. Several trees were cut to enlarge the opening and decrease vegetation effects on environment factors. The annual environment summary for 1952-1953 is in Appendix II. The texture of the soil is revealed by mechanical analysis data given in Table 2 .

The abundance of young trees, absence of mature trees, and presence of many stumps that have greater diameters than any living trees indicate that this is an unstable or successional stand. Tree ages reveal that the stand began development after a period of lumbering about 90 years ago. The climax of the succession that is in progress on this site will be an open ponderosa pine stand. This conclusion is based on 3 types of evidence: knowledge of the universal process of succession, publications on the ecology of this type of site, and data on stumps and other features of the eurrent stand collected for the present study. The climax stand may be an edaphic, rather than a true climatic, climax because the nature of the soil parent material may prohibit development of a sufficiently fine soil for a climatic climax.

Stand A-3 is a mosaic of different-sized patches of ponderosa pine and of herbs. It lies on a south-facing slope (18\% slope) immediately south of Stand A-1 and at approximatcly the same altitude. Several pines 43 feet tall, 18 inches in diameter, and about 100 years old, stand out conspicuously above an abundance of younger trees. Stumps are rare, none being found in our quadrats. Three Douglasfir seedlings and saplings have been found in the stand, but the absence of Douglasfir stumps and regional ecology of the species indicate that this species will never be prominent in this stand-type. A single plant of Rubus deliciosus James was the only shrub found in 6 quadrats.

Boutelou gracilis is the most distinctive plant in the herb synusia of Stand A-3, because it is lacking in Stand A-1; all other herbs are common to both stands. Quantitative data on the herbs are given in Table 4. 
Table 4. A-Ponderosa Pine Stand Vegetation Data

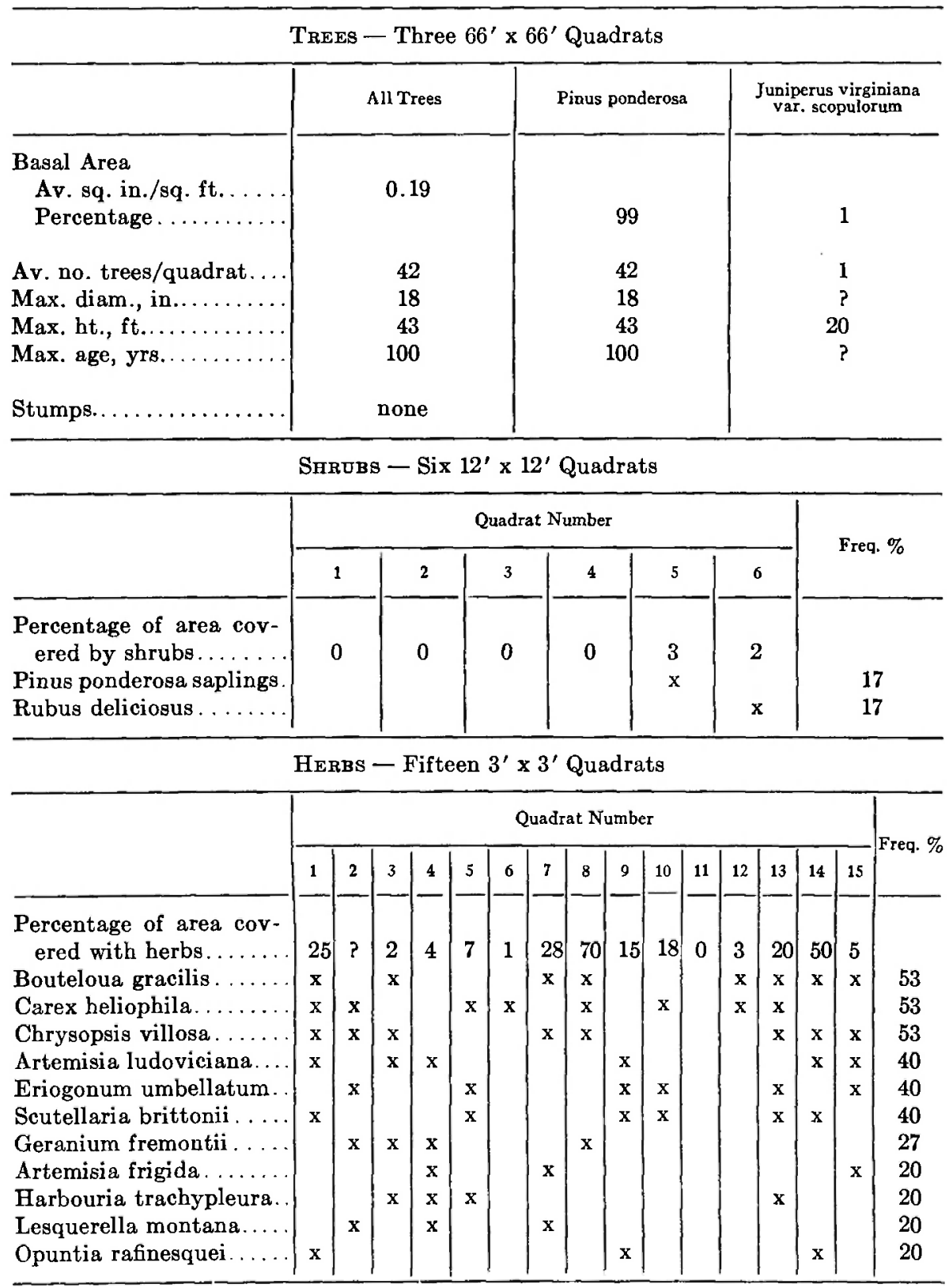

Note: Twenty other species with a frequency of less than 20 per cent are given in the species list in Appen. dix I. 
The absence of recent fires and of strong wind at the ground level and the dryness of the environment have permitted deep accumulation of needles under the pines. Herbs are rare under the trees, but grow in bunches that often form the bank part of microterraces only a few inches across in the openings between trees. The platform of each terrace has a gravel surface and is plant free.

The A-3 environment-measurement station was located in a grassy clearing enlarged by removal of a few trees. The annual environment summary for A-3 is in Appendix II; soil data are in Table 2. Since Stands A-3 and A-1 have similar vegetation but are on different topographic situations, it is interesting to compare the factors measured in the two stands. Table 5 summarizes these factors and reveals that they are quite similar. The only conspicuous differences were that soil temperatures averaged about $5^{\circ}$ higher at A-3, there was about $50 \%$ more wind at $\mathrm{A}-1$ than at $\mathrm{A}-3$, and soil depth was definitely greater in A-3. These differences, and perhaps others not measured, resulted in a total environment slightly less mesic at A-3 than at A-1.

The status of Stand $\Lambda-3$ and the explanation of the origin of its characteristics are an interesting ecological story, because several of its features appear at first observation to be incongruous. The presence of many large and older trees suggests a relatively stable unit long free from disturbance. The abundance of young trees suggests an unstable unit that experienced disturbance not long ago, but a careful search fails to reveal the usual signs of disturbance, such as fire scars or stumps left by lumbering. The presence of this same combination of puzzling features in many stands in Boulder County makes the search for an explanation of Stand A-3 especially interesting. A study in eastern Washington (Rummell, 1951), evidence gleaned from Vestal's 1917 paper, and my own observations and review of the region's history lead to the following interpretation:

A very open ponderosa pine-grass stand, perhaps a true park-land type, occupied this site about 100 years ago. Tree seedlings were unsuccessful in competition with the herbs, and consequently tree density was kept relatively low. Grazing by the cattle of early settlers weakened and/or partially destroyed the herb ground cover. Tree seedlings, no longer encountering severe competition, developed in abundance in years when there was a coincidence of a good seed crop and favorable spring-summer weather, but cattle destroyed or damaged many of the seedlings and few achieved the dimensions of trees. At a still later date, grazing pressure was reduced, seasonally if not annually, and a large number of seedlings grew into saplings which subsequently formed the current dense patches of younger trees.

It is possible that repeated fires rather than competition inhibited tree repro- 
TABLE 5. Comparison of Four Stands in the Lower Montane Climax Region

\begin{tabular}{|c|c|c|c|c|}
\hline & \multicolumn{4}{|c|}{ Stands } \\
\hline & $\begin{array}{l}\text { A-3 Pondero5a } \\
\text { Pine }\end{array}$ & $\begin{array}{l}\text { A-1 Ponderosa } \\
\text { Pine }\end{array}$ & $\mid \begin{array}{l}\text { A-2 Douglasgir- } \\
\text { Ponderosa Pize }\end{array}$ & $\begin{array}{l}\text { A-4 Valley. } \\
\text { Floor Stands: }\end{array}$ \\
\hline Altitude, ft.......... & 7,200 & 7,200 & 7,200 & 7,500 \\
\hline Exposure........ & S-facing & Ridge top & $\mathrm{N}$-facing & Valley Floor \\
\hline \multicolumn{5}{|l|}{$\begin{array}{l}\text { Yearly Features of Environment } \\
\text { Factors: }\end{array}$} \\
\hline $\begin{array}{l}\text { Air temperature, degrees } F \\
\text { Maximum } \ldots \ldots \ldots \ldots \ldots \ldots \ldots\end{array}$ & 97 & 96 & 94 & 87 \\
\hline 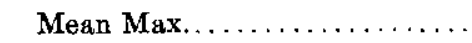 & 61 & 59 & 57 & 54 \\
\hline Minimum $\ldots \ldots \ldots \ldots \ldots \ldots$ & -2 & -3 & -4 & -18 \\
\hline Mean Min. . . . . . . . . . . . . & 35 & 35 & 34 & 25 \\
\hline Mean...$\ldots \ldots \ldots \ldots \ldots \ldots$ & 48 & 47 & 45 & 39 \\
\hline Longest freeze-free period, days. . & 139 & 137 & 136 & 89 \\
\hline \multicolumn{5}{|l|}{ Soil temperature, degrees $F$. } \\
\hline Maximum ........... & 85 & 80 & 79 & 73 \\
\hline Mean $\operatorname{Max} . \ldots \ldots \ldots \ldots \ldots$ & 59 & 53 & 48 & 50 \\
\hline Minimum $\ldots \ldots \ldots \ldots \ldots$ & 29 & 25 & 23 & 20 \\
\hline Mean Min. $\ldots \ldots \ldots \ldots \ldots \ldots$ & 44 & 41 & 39 & 39 \\
\hline Mean.................. & 52 & 47 & 43 & 44 \\
\hline \multicolumn{5}{|l|}{ 12-inch depth: } \\
\hline Mean...$\ldots \ldots$ & 51 & 46 & 43 & 44 \\
\hline Wind, total miles............ & 37,649 & 57,698 & 39,930 & 27,678 \\
\hline 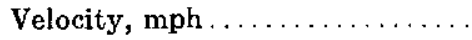 & 4 & 7 & 5 & 3 \\
\hline Precipitation, in............ & 20 & 20 & 20 & 19 \\
\hline \multicolumn{5}{|l|}{ Maximum snow depth, in. (with } \\
\hline $\min$, of drifting) . . . . . & 12 & 12 & 12 & 9 \\
\hline \multicolumn{5}{|l|}{ Soil moisture, $\%$ dry wt. } \\
\hline $5-7^{\prime \prime}$ depth, mean ..... & 8 & 7 & 6 & 5 \\
\hline $11-13^{\prime \prime}$ depth, mean.... & 7 & 7 & 6 & 4 \\
\hline Mean relative humidity. . & 58 & 53 & 59 & 69 \\
\hline
\end{tabular}

"This site was 300 feet higher and 2 miles closer to the Divide than the other three "A" sites.

duction in this site in pre-settlement days (Cooper, 1960). The low productivity of herbage and the absence of fire scars on the older trees, however, lead me to think that competition was the probable control.

The present stand is definitely a successional unit. It will undergo conspicuous changes in the density of the different species although the species composition will change little or not at all. The stable ecosystem on this site will be an open park-land stand of ponderosa pine and herbs, a topographic climax. 


\section{b. Douglasfir-Ponderosa Pine Stand Complex}

Another complex of stands that must be studied in greater detail before individual stand-types can be identified is that of Douglasfir-ponderosa pine. The stands are characterized by a dominance of Douglasfir over ponderosa pine and a greater density of trees than in other lower montane stands. Tree crowns generally touch, but rarely overlap. Several shrubs and herbs are common, but they never produce a continuous synusia.

Stand A-2 was studied in detail. It lies 200 yards west of A-1 on the northfacing slope of the Bummer's Gulch Ridge about 100 feet vertically below the crest of the ridge. The stand area has a general slope of approximately $18 \%$. It is a conglomeration of sub-stands produced by small-scale disturbances and variations in soil parent material and angle of slope. A few trees of both species are over 80 years old. Young trees form thickets difficult to walk through, in which Douglasfir seedlings are abundant. Most openings in the tree synusia originated from cutting and are now well stocked with tree seedlings and saplings. Small aspen trees are common on the lower slope. Table 6 gives quantitative data on plants.

The A-2 environment-measurement station was located in the upper part of the stand in a clearing produced by the outcropping of a rock type on which little soil has developed. An annual summary of environment is in Appendix II; Table 2 gives data on soil.

Stands A-2 and A-3 are about 200 yards apart at approximately the same altitude on the north- and south-facing slopes of one ridge and therefore illustrate difference in stands resulting from variation in topography. Table $5 \mathrm{com}$ pares some features of the stands. A-2 was cooler than A-3; although there was a difference of only a few degrees in air temperature, soil-temperature differences ranged from $5^{\circ}$ to $11^{\circ}$, depending on which feature of the factor is under comparison. A-2 had a deeper snow cover from February to April. Soil moisture was about the same during the growing season but higher at A-3 during the winter. There was no conspicuous difference between the two stands in the other factors measured.

This stand is successional. Many of its features, such as the abundance of pine and Douglasfir saplings and shrubs and the presence of aspen, are products of the lumbering that left the many stumps listed in Table 6 . These features will be changed or eliminated from the stand through processes of ecosystem change if disturbance is not repeated. As time passes, Douglasfir will become progressively more dominant, and many of the shrubs and most or all of the aspen will be killed by shading and/or competition for water. This will open up the shrub synusia, because seeds of those species do not germinate readily under as dense a tree cover as the Douglasfir can maintain on this type of site. 
TABle 6. A-2 Douglasfir-Ponderosa Pine Stand Vegetation Data

Trees - Three $66^{\prime} \times 66^{\prime}$ Quadrats

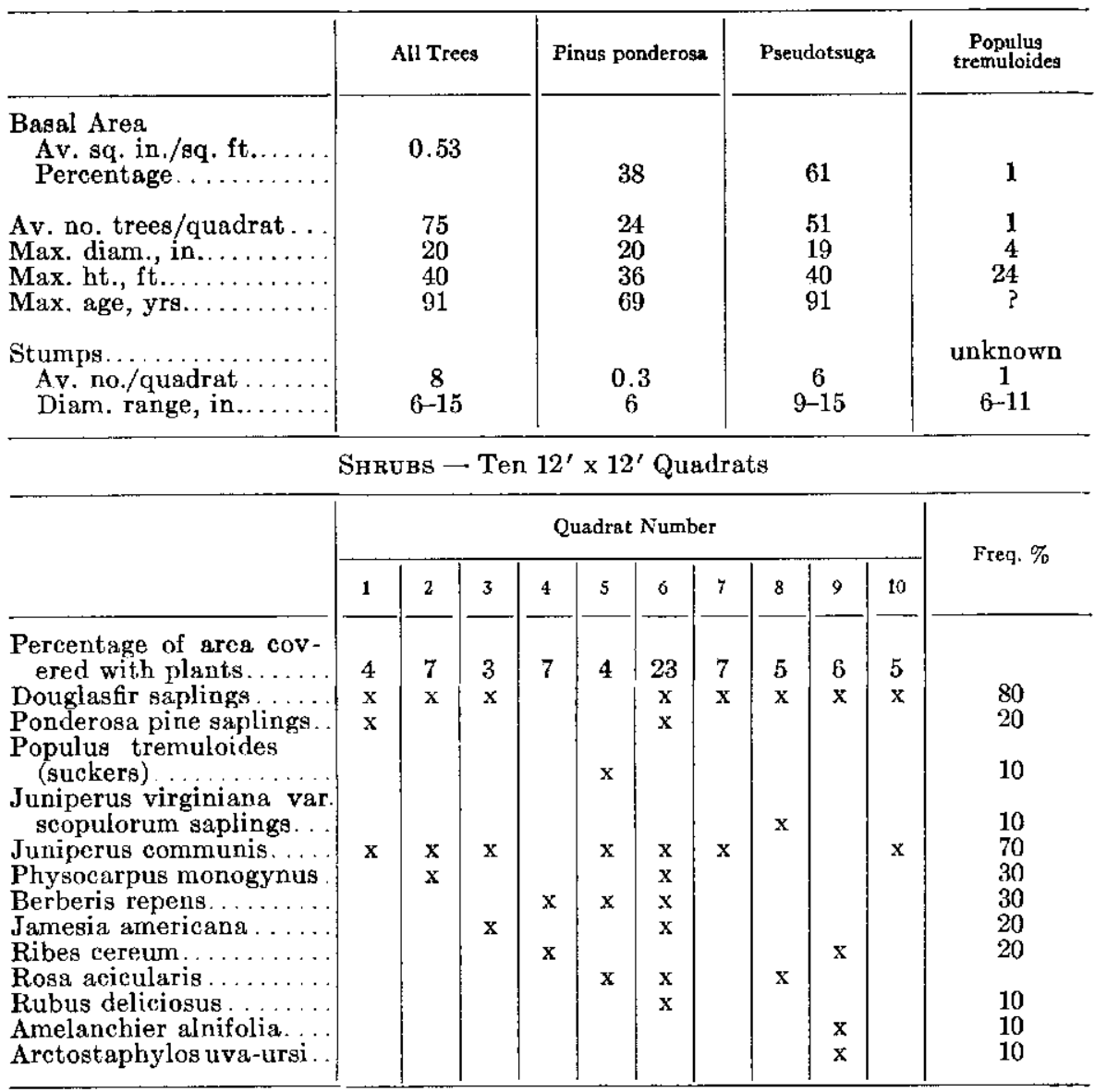

HERBs - Fifteen $3^{\prime} \times 3^{\prime}$ Quadrats

\begin{tabular}{l|l|l|l|l|l|l|l|l|l|l|l|l|l|l|l|l|l}
\hline & Quadrat Number \\
& & & \\
\hline
\end{tabular}

Note: Twenty other apecies with frequencies of lesg than 20 per cent are given in the species list in the Appendix I. 
The herb synusia will also thin out as the stand develops toward stability. Ponderosa pine will become less abundant, because its seedlings are not successful on deep litter nor in shade; but it will not disappear entirely, bccause rocky micro-sites and wind-throw of trees will provide favorable habitats in which pine seedlings may develop. The stable ecosystem of this site is a Douglasfir topographic-elimax stand. As no example of this type survived exploitation to the present day, we cannot know the details of its characteristics. The number of stumps (apparently none of the maximum size possible in this site) and basic ecological reasoning suggest that the climax will be so dense that tree crown will occupy about half of the space in the crown layer.

\section{c. Douglasfir Stand-Type}

The Douglasfir stand-type occurs on north-facing slopes somewhat steeper and therefore more mesic, owing to lower solar radiation, than site A-2. Trees in young stands grow so close together that their pyramid-shaped crowns often touch; older stands are more open. All present-day stands are successional. It is not possible to determine, as yet, the character of the potential climax on these sites; it may be almost pure Douglasfir.

\section{d. Grassland Complex}

Bunch-grass stands of one acre to many acres in extent are frequent in the lower montane, especially on ridge tops and gentle, south-facing slopes (Plate 2A). Ramaley (1916, 1916a, and 1919) describes grass-dominated stands in all the east-slope regions. Some of them appear to be related to deep soil where herbs out-compete trees. Others are obviously products of clearing and cultivation. There are probably several stand-types in this complex; some are clearly successional to open ponderosa pine-grass climaxes; it is possible that others are successional to true grass climaxes. The external stand environment of these types is comparable to that of Stands A-1 and A-3 described above.

\section{e. Valley-Floor Stand-Types}

Several types of valley-floor stands are conspicuous to mountain travelers, because they lie close to roads; but they actually make up a minor part of the landscape. Local topographic characteristies prevented us from selecting a valley study area at the same altitude as that of the other lower montane stands. The most appropriate area turned out to be the relatively broad valley of North Boulder Creek at Switzerland Park, 7,500 fect in elevation (Fig. 1). The area had been altered so much by grazing and other disturbances that quadrat studies were omitted. A species list of the area's plants has been prepared and is given in Appendix I. 
The environment data from Station A-4 are given in Appendix II. Data from this station are particularly valuable, because the station is almost straight down-slope from Stations B-1 and B-3 and therefore provides a means of studying the effects of topography and altitude on other environment factors. Detailed analyses of these data are being carried out under another program and are not appropriate for the present paper. Comparisons with the other lower montane stations (Table 5) are desirable at this point, however. It is necessary to keep in mind the faet that A-4 was at an elevation about 300 feet higher than the other " $A$ " stations and that its soil was more sandy.

A-4 was distinctly colder than the other stations, in part, at least, because it was often chilled by nocturnal "cold-air drainage". The valley-floor site receives a flow of colder and therefore more dense air from surrounding slopes and from farther up the valley. Winds are relatively low, only half as much as at $\mathrm{A}-\mathrm{l}$, and this condition permits the cold air to accumulate. The temperature on a given night was as much as $26^{\circ}$ colder at A-4 than at other stations. Furthermore, the summer period of days without freezing temperatures was only 89 at A-4 and over 139 at A-1, being shortened by the cold-air drainage at A-4. Average relative humidity was higher at A-4 than at other stations, probably as a result of the lower night temperatures.

The following stand-types are common in valley-floor sites:

Cottonwood Stand-Type: Groves of cottonwood trees, largely Populus angustifolia, grow on river floodplains, forming narrow and discontinuous bands along valley floors. Colorado blue spruce, Douglasfir, ponderosa pine, and Rocky Mountain juniper may be mixed with the cottonwood. Tall shrubs of alder (Alnus tenuifolia Nutt.), willow, birch, and chokecherry (Prunus virginiana L.), form a dense undergrowth in undisturbed stands.

Willow-Alder Stand-Type: Banks of streams, seepage areas, and other sites with high water tables usually support shrub thickets of willow or alder or a mixture of the two species. In open sites, they are only a few feet tall, but in shaded areas they may be up to 10 feet tall.

Wet Montane Meadow Stand-Type: In this stand turf-forming grasses and sedges form a solid plant cover. It is found in shallow valleys where the water table is near the surface and streams are intermittent, if present at all.

Western River Birch Stand-Type: Western river birch (Betula occidentalis Hook.), is common in the mixed shrub-tree stands of stream-sides in the upper part of the lower montane. Distinct birch stands, lacking trees but including several other shrubs, occur in some valley sites.

All of the present-day stands of the foregoing types are either successional or biotic-elimax stands. In the absence of disturbance, they would change to climaxes controlled by deep soil and higher water table. It is not possible to- 
day to get much of an idea about the character of these potential climaxes, because the history of disturbance has been long and varied. Most of the current species would probably be represented in the climaxes, but their relative importance would be different. Young's 1907 paper describes several of these units in relatively early stages of alteration.

\section{B. The Upper Montane Forest Chimax Region}

\section{REGIONAL CHARACTERISTICS}

Geography and Geology: The upper montane region has been called the Douglasfir zone, the Douglasfir climax, and the montane zone. It lies between the lower montane and the subalpine regions, with altitudinal limits of approximately 8,000 and 9,000 feet. As their names imply, the lower montane and upper montane regions are more closely related than most pairs of adjacent regions. They differ very little in many characteristics, but some features, such as the role of Douglasfir, are distinctive and require that the two regions be kept separate. The upper montane occupies the Rocky Mountain surface of comparatively broad interstream areas and relatively gentle increase in regional altitude from east to west. Many ridges, however, are narrow-topped and have steep slopes, generally steeper when north-facing than when southfacing. Valleys in the upper altitudes are broad as a result of glaciation, but they often become very narrow at lower altitudes. Glacial moraines occur in some of the wider valleys. Small lakes and ponds are common.

The country rock of granites, granodiorites, schists, and gneisses is abundantly exposed in rocky knobs, cliffs, and talus slopes. Boulders weathering in place on ridge tops usually have the rounded form typical of the entire montane environment. Talus-slope boulders and outcrops of resistant dikes are angular. Deposits that may be ancient glacial till occur in a few sites, and the larger valleys have more recent glacial and glacial-fluvial deposits in the form of subdued moraines and terraces on their floors. River floodplains are generally wider in this region than in the lower montane.

Soils: Soils (Table 7) are similar to those of the lower montane described above.

Climate: The climate is also similar to that of the lower montane, being cooler and more humid, but otherwise little different in the factors we measured. Quantitative data on the climax-region environment are given in Appendix II on the B-1 Douglasfir-ponderosa pine stand.

Vegetation: The upper montane vegetation consists of open or dense forest of Douglasfir and/or ponderosa pine, often interrupted by dense stands of slender lodgepole pine and groves of aspen trees. It resembles the lower mon- 
Table 7. Upper Montane Soils Data

\begin{tabular}{|c|c|c|c|c|c|c|}
\hline \multirow{3}{*}{ Stand } & \multirow{3}{*}{ Depth, incbes } & \multirow{3}{*}{ Soil Type } & \multicolumn{4}{|c|}{ Mechanical Analysis: Particle Size in mrn. } \\
\hline & & & \multirow{2}{*}{$\%$ over 2} & \multicolumn{3}{|c|}{ Percentages of Fraction under 2} \\
\hline & & & & $2-0.05$ & $0.05-0.002$ & $\begin{array}{l}\text { below } \\
0.002\end{array}$ \\
\hline B-1 & $\begin{array}{l}0-6 \\
6-12\end{array}$ & $\begin{array}{l}\text { Sandy loam } \\
\text { Sandy loam }\end{array}$ & $\begin{array}{l}23 \\
32\end{array}$ & $\begin{array}{l}73 \\
72\end{array}$ & $\begin{array}{l}16 \\
16\end{array}$ & $\begin{array}{l}12 \\
13\end{array}$ \\
\hline B-2 & $\begin{array}{l}0-6 \\
6-12\end{array}$ & $\begin{array}{l}\text { Sandy loam } \\
\text { Sandy loam }\end{array}$ & $\begin{array}{l}34 \\
30\end{array}$ & $\begin{array}{l}68 \\
69\end{array}$ & $\begin{array}{l}21 \\
23\end{array}$ & $\begin{array}{r}11 \\
9\end{array}$ \\
\hline B-3 & $\begin{array}{l}0-6 \\
6-12\end{array}$ & $\begin{array}{l}\text { Loamy sand } \\
\text { Sandy loam }\end{array}$ & $\begin{array}{l}20 \\
23\end{array}$ & $\begin{array}{l}79 \\
77\end{array}$ & $\begin{array}{l}14 \\
14\end{array}$ & $\begin{array}{l}8 \\
9\end{array}$ \\
\hline B-4 & $\begin{array}{l}0-6 \\
6-12\end{array}$ & $\begin{array}{l}\text { Sandy loam } \\
\text { Sandy loam }\end{array}$ & $\begin{array}{l}6 \\
7\end{array}$ & $\begin{array}{l}75 \\
77\end{array}$ & $\begin{array}{l}17 \\
14\end{array}$ & $\begin{array}{l}9 \\
9\end{array}$ \\
\hline
\end{tabular}

tane vegetation, but differs from it in a greater over-all density of forest, greater abundance of Douglasfir on south-facing slopes, and the presence of lodgepole pine stands and aspen stands on upland sites. Mature trees average 45 feet in height.

Ridge tops and gently rolling uplands with decp soil support forest of mixed Douglasfir and ponderosa pire. (In the most favorable tree habitats, the former would exclude the latter entirely if left undisturbed for several hundred years.) The same forest type, except for being a bit more open, extends down the upper part of south-facing slopes. If the slope remains gentle and soils are deep, Douglasfir becomes inconspicuous or even disappears. Where the slope is steep and the soil rocky, Douglasfir accompanies the pine to the valley floor. Dry grassland stands aro common on habitats of fine, deep soil that are frequent on the lower part of the south-facing slopes.

Valley floors are similar to those in the lower montane. On narrow floors, dense shrub or forest stands crowd the river banks. Aspen and Colorado blue spruce, Erigelmann spruce, subalpine fir, and lodgepole pine may grow with the more common cottonwood and upland dominants on the floodplains. Broad valley floors oriented east-west, have wet meadows along their north side and dense shrubs along the drainage lines. A shrub zone may extend southward from the drainage channel until it mects the dense forest zone on the soutbernmost side of the floor. There is a tendency for zonation in the distribution of the different tree specics, with aspen next to the shrubs, and spruce 
and fir in the next zone. Lodgepole pine may be mixed with the spruce and fir and also in the next zone with the upland trees.

North-facing slopes are dominated by Douglasfir wherever conditions are moderate. Ponderosa pine is rare but always is present in these stands, and it is abundant, sometimes dominant, in young stands and on unusually coarse or shallow soil. Open stands of ponderosa pine form topoedaphic climaxes on south-facing slopes.

Three forest stand-types that do not occur in the lower montane have a strong influence on the general appearance of the upper montane. Limber pine groves occur on special sites where wind is excessive and/or soil is unusually coarse. Some of them are successional, but others are topographic or topoedaphic climaxes. Two types of successional stands, one dominated by aspen and the other by lodgepole pine, occur whenever an area has been disturbed by cultivation, lumbering, or fire in the last few hundred years. These stands may be extensive, even to the total absence of the climax species, but they always bear some characteristics that tie them to a climax stand-type. Details of these alterations of stands and subsequent trends in succession have been investigated by several authors. Johnson studied these processes in the ponderosa pine type (1945). The role of fire was described by Clements in 1910 and by Sperry in 1936.

Herb-dominated stands frequently interrupt the prevailing forest cover of the upper montane. Nutural herb stands are most common around the shallow lakes and ponds that occupy variable, but usually gentle-sloped, depressions of the Rocky Mountain surface. Several types of stands form zones around the open water, and similar stands occur in depressions that have a higher water table but no open water. Another type of herb stand exists where the trees have been removed to encourage grasses for grazing. I have not yet studied any of these herb stands in detail.

\section{THE MAJOR STAND-TYPES}

\section{a. Douglasfir-Ponderosa Pine Complex}

\section{(1) General Features}

This complex was described in the section above on the lower montane, where it is a topographic climax; here in the more mesic upper montane, it is the potential climatic-climax type on gently rolling uplands with deep, mature soil (Plate 2B). All of the current stands are suecessional, due to the brevity of time since the last disturbance. It is probable that this complex is not identical in the upper and lower montane regions, but there is not enough information available to make a separation. 
A more open stand of this complex is common on south-facing slopes, where it is a topographic climax. A more dense type that often contains an abundance of aspen or limber pine and in which all trees are relatively young is common on north-facing slopes. These are successional ecosystems that, if left undisturbed, will develop into a Douglasfir topographic climax, in which all of the other species may be present but unimportant.

\section{(2) Detailed Study Stands}

Two stands of this complex were studied in detail. Stand B-1 is on the crest of a hill just west of Sugarloaf Mountain (Fig. 1). This site is somewhat extreme in exposure to wind and in soil texture, but was the best climatic-climax site available at the intermediate altitude. The hill top is relatively flat for a distance of about 530 feet. A low ridge a few feet high cuts across the stand. Large ponderosa pines and Douglasfirs are scattered individually, and in small clumps, through the stand. Tree trunks occupy less than $0.14 \%$ of the total area of the stand. The largest Douglasfirs are 30 inches in diameter, but they are tipped leeward by strong winds and are only 40 feet tall. These trees are over 350 years old. Closed patches of herbs and the creeping shrub Arctostaphylos uva-ursi alternate with patches of almost bare soil. There is no evidence of fire. Table 8 gives quantitative data on the plants.

This stand was selected for study because it came closest to the requirements of the project design; it was on a ridge-top at an intermediate altitude in the range of the upper montane and was comparable to the study sites in the other three regions. The vegetation and soil parent material are not, unfortunately, average for this stand-type. 'The parent material, soil, and lumbering vary enough to affect vegetation conspicuously. The result is a mosaic of "patches", each with its own peculiar combination of ecosystem components. Where trees were cut or blown over many years ago, there is an abundance of reproduction. Where the soil is shallow or very coarse, ponderosa pine is relatively abundant. Patches of deeper soil have an abundance of herbs and Arctostaphylos.

Comparison of B-1 and A-1 vegetation reveals that Douglasfir makes up a higher percentage of the tree basal area in the former stand. There are more shrubs in B-1, but this is not significant - the same species occur in both regions, varying in abundance largely as a result of disturbance factors. Four species of herbs with a frequency above $20 \%$ are common to both stands, 4 of A-1's are lacking in B-1 and 6 of B-1's are lacking in A-1. The patch of limber pine in one segment of B-1 stand results from disturbance. This species is successional in this site (horizontal ground surface) although it is climax on surfaces tipped into strong wind (see below). 


\begin{tabular}{|c|c|c|c|c|c|c|c|c|c|c|c|c|c|c|c|c|c|}
\hline \multicolumn{18}{|c|}{ 'T'REEs - Four 66' x 66' Quadrats } \\
\hline & \multicolumn{4}{|c|}{ All Trees } & \multicolumn{5}{|c|}{ Pinus ponderosa } & \multicolumn{4}{|c|}{ Pseudotsuga } & \multicolumn{4}{|c|}{ Pinus flexilis } \\
\hline $\begin{array}{l}\text { Basal Area } \\
\text { Av. sq. in./sq. ft..... } \\
\text { Percentage ......... }\end{array}$ & \multicolumn{4}{|c|}{0.19} & \multicolumn{5}{|c|}{26} & \multicolumn{4}{|c|}{68} & \multicolumn{4}{|c|}{5} \\
\hline $\begin{array}{l}\text { Av. no. trees/quadrat. } \\
\text { Max. diam., in....... } \\
\text { Max. ht., ft......... } \\
\text { Max, age, yrs........ }\end{array}$ & \multicolumn{4}{|c|}{$\begin{array}{c}? \\
30 \\
35 \\
300+\end{array}$} & \multicolumn{5}{|c|}{$\begin{array}{r}12 \\
35 \\
122\end{array}$} & \multicolumn{4}{|c|}{$\begin{array}{l}30 \\
35 \\
300+\end{array}$} & \multicolumn{4}{|c|}{$\begin{array}{c}? \\
30 \\
?\end{array}$} \\
\hline Stumps. & \multicolumn{17}{|c|}{ None in quadrats but several in stand. } \\
\hline \multicolumn{18}{|c|}{ Shrubs - Eight $12^{\prime} \times 12^{\prime}$ Quadrats } \\
\hline & \multicolumn{15}{|c|}{ Quadrat Number } & \multirow{2}{*}{\multicolumn{2}{|c|}{ Freq. \% }} \\
\hline & 1 & & 2 & & 3 & & 4 & & 3 & & 6 & 7 & & 8 & 3 & & \\
\hline 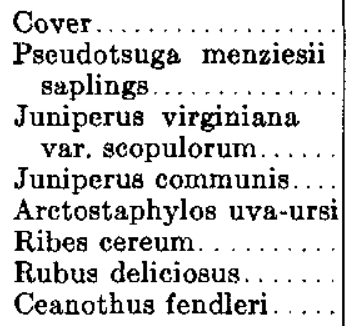 & \multicolumn{2}{|c|}{0} & \multicolumn{2}{|c|}{25} & \multicolumn{3}{|l|}{$\begin{array}{l}x \\
x \\
x\end{array}$} & \multicolumn{2}{|r|}{0} & \multicolumn{2}{|r|}{8} & \multicolumn{2}{|c|}{$\begin{array}{l}\mathbf{x} \\
\mathbf{x}\end{array}$} & \multicolumn{2}{|c|}{1} & \multicolumn{2}{|c|}{$\begin{array}{l}13 \\
13 \\
13 \\
25 \\
13 \\
13 \\
13\end{array}$} \\
\hline \multicolumn{18}{|c|}{ Herbs - Sixteen $3^{\prime} \times 3^{\prime}$ Quadrats } \\
\hline & \multicolumn{16}{|c|}{ Quadrat Number } & so \\
\hline & 1 & 2 & 3 & 4 & 5 & 6 & 7 & 8 & 9 & 10 & 11 & 12 & 13 & 14 & 15 & 16 & 总 \\
\hline $\begin{array}{c}\text { Percentage of area cov- } \\
\text { ered with plants..... } \\
\text { Carex heliophila...... } \\
\text { Hesperochloa kingii.... } \\
\text { Penstemon virens...... } \\
\text { Potentilla fissa......... } \\
\text { Achillea lanulosa...... } \\
\text { Artemisia ludoviciana. } \\
\text { Harbouria trachypleura } \\
\text { Lithospermum incisum. } \\
\text { Geranium fremontii.... } \\
\text { Sedum lanceolatum.... }\end{array}$ & $\begin{array}{l}20 \\
\mathrm{x} \\
\mathrm{x} \\
\mathrm{x} \\
\mathrm{x}\end{array}$ & $\begin{array}{l}2 \\
\mathrm{x} \\
\mathrm{x} \\
\mathrm{x} \\
\mathrm{x}\end{array}$ & $\begin{array}{l}2 \\
x \\
x \\
x \\
x \\
x\end{array}$ & $\begin{array}{l}25 \\
x \\
x \\
x \\
x \\
x\end{array}$ & $\mathbf{0}$ & $\mathrm{x}$ & $x$ & $\begin{array}{l}x \\
x \\
x\end{array}$ & $\begin{array}{l}15 \\
\mathrm{x} \\
\mathrm{x} \\
\mathrm{x} \\
\mathrm{x}\end{array}$ & 1 & $\left|\begin{array}{l}2 \\
x \\
x \\
x\end{array}\right|$ & $\mathbf{x}$ & $\mathrm{x}$ & $\begin{array}{l}27 \\
\mathrm{x} \\
\mathrm{x} \\
\mathrm{x} \\
\mathrm{x} \\
\mathrm{x} \\
\mathrm{x}\end{array}$ & 0 & 2 & $\begin{array}{l}45 \\
45 \\
45 \\
38 \\
31 \\
31 \\
31 \\
31 \\
25 \\
25\end{array}$ \\
\hline
\end{tabular}

Note: Twenty other speeies with a frequency of lesa than 20 per cent are given in the specieg list in Appendix I. 
An annual summary of the external stand environment data collected at a station in an open area near the center of the stand is in Appendix II; Table 7 gives data on soil. The maximum temperature of $72^{\circ} \mathrm{F}$ at 6 inches was lower than the same feature at the two slope stations where the readings were $82^{\circ} \mathrm{F}$ and $81^{\circ} \mathrm{F}$ (Table 11 ). We suspected that the $\mathrm{B}-1$ reading was erroneous but have found similar apparent irregularities throughout 8 years of observations and conclude, therefore, that the measurement was accurate but that there is some peculiarity in the microsite of the instrument.

Comparison of B-1 and A-1 (Table 9), the climatic-climax stand sites of the two montane regions, shows that there is not much difference in some of their environment factors, a fact that one is led to suspect by the similarity of the vegetation of the two regions. Air temperatures were about $5^{\circ}$ lower at B-1, soil temperatures $3^{\circ}$ to $8^{\circ}$ lower at B-1, and the summer period free from freezing temperature was over $30 \%$ longer at $\Lambda$-1. Relative humidity was somewhat higher at B-1, probably as a result of the lower temperature. Precipitation and wind differed little between the two stands.

The current stand is successional, due to disturbances. Stump analysis showed that the stand that oceupied this site before the lumbering had about equal numbers of the two dominant trees with individuals up to 24 inches in diameter. Reproduction today indicates that ecosystem change is tending to reestablish the same type of unit. The potential climax stand will be broken into many patches by the diversity of the parent material.

Stand B-2 is on a $13 \%$ slope north of and about 100 feet below Stand B-1. Aspen, Douglasfir, ponderosa pine, and a few limber pines grow so close together in some patches that one can just barely walk between them, although more open patches and corridors do occur here and there. Aspen average 18 feet tall, and some of the gymnosperms are a bit taller. The aspen rarely achieve over 4 inches in diameter before dying under the intense competition, but they "sucker out" freely and are therefore more numerous than the other species in parts of the stand. As the gymnosperms become more dense the aspen will be reduced to a few straggling individuals. There are many stumps, predominantly Douglasfir, but no evidence of fire.

Quantitative data on the vegetation are given in Table 10. Ponderosa pine is less abundant than in the other $B$ stands, and aspen and lodgepole pine make their first appearance here, the former in abundance. General regional observations have shown that these two successional species are rarely abundant at any altitude lower than the 8,500 feet of this stand; even at this altitude they are not common on topographic sites other than north-facing slopes.

The low shrubs Juniperus communis L. and Arctostaphylos uva-ursi have high frequencies and cover much of the ground surface. Several new herbs occur in this stand, but none is abundant. 
TABLE 9. Comparison of Four Climax Regions

(Environment factors measured in one climatic-climax site in each region)

\begin{tabular}{|c|c|c|c|c|}
\hline & Lower Montane & Upper Montane & Subalpine & Alpine \\
\hline Climatic-Climax Stand-Type... & $\begin{array}{l}\text { Ponderosa } \\
\text { Pine } \\
\text { Forest }\end{array}$ & $\begin{array}{l}\text { Douglasfir- } \\
\text { Ponderosa } \\
\text { Pine } \\
\text { Forest }\end{array}$ & $\begin{array}{c}\text { Engelmann } \\
\text { Spruce- } \\
\text { Subalpine } \\
\text { Fir Forest }\end{array}$ & $\begin{array}{l}\text { Kobresia } \\
\text { Meadow } \\
\text { Tundra }\end{array}$ \\
\hline Altitude, ft.... & 7,200 & 8,500 & 10,000 & 12,300 \\
\hline \multicolumn{5}{|l|}{$\begin{array}{l}\text { Yearly Features of Environment } \\
\text { Factors: } \\
\text { Air temperature, degrees } F \text {. }\end{array}$} \\
\hline 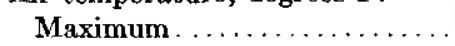 & 96 & 89 & 75 & 62 \\
\hline Mean Max................ & 59 & 54 & 44 & 32 \\
\hline Minimum................ & -3 & -7 & -14 & -18 \\
\hline Mean Min. . . . . . . . . . . & 35 & 30 & 24 & 19 \\
\hline Mean $\ldots \ldots \ldots \ldots \ldots \ldots$ & 47 & 42 & 34 & 25 \\
\hline Longest freeze-free period, days. & $137+$ & 100 & 87 & 45 \\
\hline \multicolumn{5}{|l|}{$\begin{array}{l}\text { Soil temperature, degrees } \mathrm{F} \text {. } \\
6 \text { inch depth }\end{array}$} \\
\hline Maximum .............. & 80 & 72 & 72 & 53 \\
\hline Mean Max............. & 53 & 47 & 46 & 33 \\
\hline Minimum............. & 25 & 21 & 18 & 6 \\
\hline Mean Min. . . . . . . . . . & 41 & 39 & 34 & 26 \\
\hline Mean $\ldots \ldots \ldots \ldots \ldots \ldots$ & 47 & 43 & 40 & 29 \\
\hline \multicolumn{5}{|l|}{12 inch depth } \\
\hline Mean ....... & 46 & 43 & 40 & 29 \\
\hline Wind, total miles. . & 57,700 & 61,600 & 91,300 & 160,000 \\
\hline Velocity, mph. & 7 & 7 & 10 & 18 \\
\hline Precipitation, in......... & 20 & 21 & 26 & 26 \\
\hline $\begin{array}{l}\text { Maximum snow depth, in. (with } \\
\text { min. of drifting) ........... }\end{array}$ & 12 & 11 & 60 & all drifted \\
\hline Soil moisture, \% dry wt. & & & & \\
\hline 5-7" deptb, mean ....... & 7 & 7 & 10 & 32 \\
\hline $11-13^{\prime \prime}$ depth, mean ..... & 8 & 7 & 11 & 16 \\
\hline Mean relative humidity........ & 53 & 60 & 62 & 70 \\
\hline
\end{tabular}

Environment data were collected in a clearing made in a patch of aspen that were rather dwarfed and lacked vigor. The annual environment summary is in Appendix II; Table 7 gives data on soil. This stand was cooler by $2^{\circ}$ or $3^{\circ}$ than the south slope Stand B-3 (Table 11). Soil-temperature maximums were similar, but B-2 was $5^{\circ}$ to $7^{\circ}$ cooler in other features of soil tempcrature. B-3 had a freeze-free interval over $40 \%$ longer than that of B-2. B-2 had a deeper snow cover, and it remained for a longer period. 
Table 10. B-2 Douglasfir-Ponderosa Pine Stand Vegetation Data

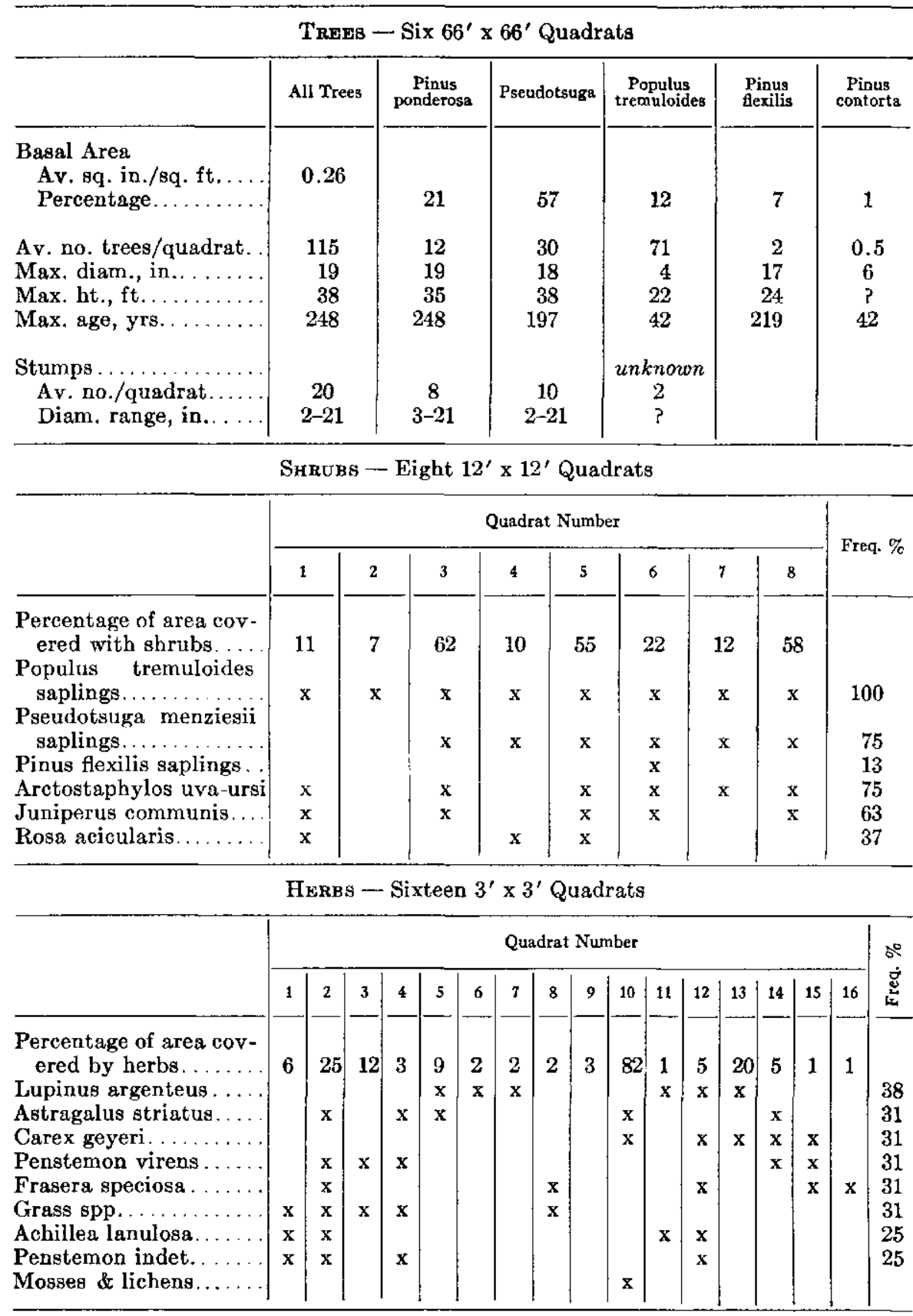

Note: Thirty other epecies witb a frequency of less tban 20 per cent are given in the apecies list in Appendix $I$. 
TABLE 11. Comparison of Four Stands in the Upper Montane Climax Region

\begin{tabular}{|c|c|c|c|c|}
\hline & \multicolumn{4}{|c|}{ Stands } \\
\hline & $\begin{array}{l}\text { B-3 Ponderosa } \\
\text { Pine-Douglasfir }\end{array}$ & $\begin{array}{l}\text { B-1 Douglasfir- } \\
\text { Ponderosa Pine }\end{array}$ & $\begin{array}{l}\text { B-2 Douglasfir- } \\
\text { Ponderosa Pine }\end{array}$ & $\begin{array}{l}\text { B-4 Valley } \\
\text { Stands* }\end{array}$ \\
\hline Altitude, ft. & 8,500 & 8,500 & 8,500 & 8,200 \\
\hline Exposure...... & S-facing & Ridge top & $\mathrm{N}$-facing & Valley floor \\
\hline \multirow{2}{*}{\multicolumn{5}{|c|}{$\begin{array}{l}\text { Yearly Features of Environment } \\
\text { Factors: }\end{array}$}} \\
\hline & & & & \\
\hline \multicolumn{5}{|l|}{ Air temperature, degrees F. } \\
\hline 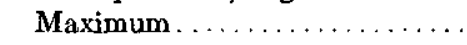 & 89 & 89 & 87 & 84 \\
\hline Mean Max............ & 54 & $\check{\partial 4}$ & 51 & 52 \\
\hline Minimum $\ldots \ldots \ldots \ldots$ & $-\mathbf{5}$ & -7 & -7 & -20 \\
\hline Mean Min. . & 33 & 30 & 30 & 25 \\
\hline Mean....... & 43 & 42 & 41 & 38 \\
\hline Longest freeze-free period, days. . & 134 & 100 & 103 & 75 \\
\hline \multicolumn{5}{|l|}{ Soil temperature, degrees $F$. } \\
\hline \multicolumn{5}{|l|}{6 inch depth } \\
\hline Maximum & 82 & 72 & 81 & 74 \\
\hline Mean Max............ & 56 & 47 & 47 & 51 \\
\hline Minimum........... & 25 & 21 & 20 & 18 \\
\hline Mean Min... & 41 & 39 & 36 & 38 \\
\hline Menn...... & 49 & 43 & 42 & 45 \\
\hline \multicolumn{5}{|l|}{12 inch depth } \\
\hline Mean..... & 48 & 43 & 41 & 44 \\
\hline Wind, total miles. & 45,496 & 61,590 & 46,152 & 70,442 \\
\hline Velocity, mph.... & 5 & 7 & 5 & 8 \\
\hline Precipitation, in . . . . . . . & 20 & 21 & 20 & 17 \\
\hline \multicolumn{5}{|l|}{ Maximum snow depth, in. (with } \\
\hline minimum of drifting) . ....... & 9 & 11 & 18 & 11 \\
\hline \multicolumn{5}{|l|}{ Soil moisture, \% dry wt. } \\
\hline $5-7^{\prime \prime}$, mean ........... & 8 & 7 & 8 & 5 \\
\hline $11-13^{\prime \prime}$, mean $\ldots \ldots \ldots$ & 8 & 7 & 8 & 5 \\
\hline Mean relative humidity... & 55 & 60 & 62 & 60 \\
\hline
\end{tabular}

* This site was 300 feet lower and 3 miles closer to the Divide than the other three " $B$ " sites.

B-2 is a complex successional stand. Stumps, seedlings, and saplings are largely Douglasfir and ponderosa pine. These features indicate that this is a Douglasfir-ponderosa pine site and that successional processes will re-establish that type of topoedaphic-climax stand if disturbance is not repeated.

\section{b. Ponderosa Pine-Douglasfir Stand-Type}

Stand B-3 is on the south-facing slope immediately south of B-1. The stand has a slope of $18 \%$. Boulders and rock outcrops are abundant, and 
loose cobbles and pebbles cover much of the ground. The soil is coarse and lacks a humus or even plant-debris cover except in protected spots. Surface erosion maintains micro-terraces similar to those described in Stand A-3. The tree stratum is an open growth of Douglasfir and ponderosa pine. The largest individuals are 28 inches in diameter and 59 feet tall. Rocky Mountain juniper is scattered throughout the stand, with individuals up to 15 feet tall. There are several limber pines in the stand. Herbs and tree scedlings are abundant, covering about $15 \%$ of the ground surface. Shrubs and saplings cover about $4 \%$ of the area and are concentrated around boulders and rock outcrops. There is no evidence of any important disturbances of the tree stratum for over 100 years.

Table 12 gives quantitative data on the vegetation. Ponderosa pine comprises a larger percentage of the tree basal area of the stand than does Douglasfir. The variability of tree distribution in this type of stand, even in the absence of disturbance, is evident in the wide range of total tree basal area between quadrats, 500 to 1,200 square inches. The abundance of Artemisia frigida Willd. suggests that the stand has been heavily grazed (Johnson, 1945).

External stand environment data for Station B-3 are given in Appendix II; soil data are in Table 7. Several of B-3's environment-factors achieved magnitudes comparable to those of B-1 (Table 11), but B-3 had higher soil temperatures and slightly less wind. Air temperatures were similar most of the year, but B-1 did have freezing temperature (only $29^{\circ}$ ) in September while the air at B-3 stayed above the freezing point. This difference resulted in a distinctly longer freeze-free season at $\mathrm{B}-3$.

This stand is relatively stable. Seedlings and saplings indicate that the tree species will maintain their current proportions in the future, and there is no evidence of any significant change in the other plant components. This is, therefore, a topoedaphic climax, probably the most stable unit in our research area.

\section{c. Douglasfir Stand-Type}

In the more mesic sites of the upper montane, such as a steep north-facing slope with deep soil, the elimax is probably an almost pure stand of Douglasfir. This type probably contained the finest timber in the area when lumbering operations began; consequently, no primeval samples are extant today. In the sites where this type would be expeeted to develop, there is now a mixed stand of the general Douglasfir-ponderosa pine stand-type. In a few sites, Douglasfir is already far more abundant than ponderosa pine.

It is probable that the Douglasfir stand-type is the climatic climax in most upper montane areas of the Rockies (Daubenmire, 1943), but it is prevented 
TABle 12. B-9 Ponderosa Pine-Douglasfir Stand Vegetation Data

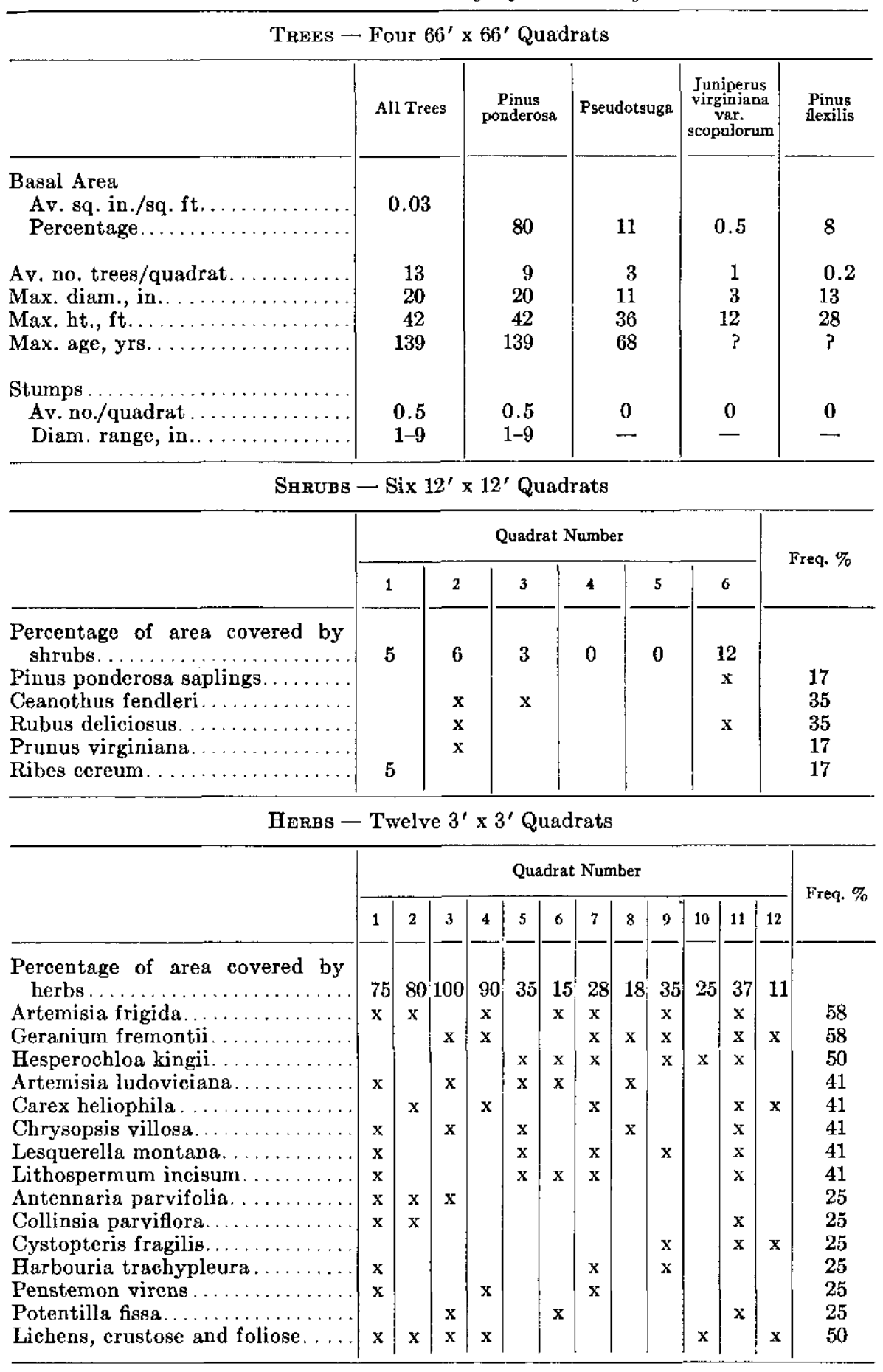

Note: Twenty other species that had a frequency of less than 20 per cent are given in the species list in Appendix I. 
from achieving that status in the Front Range because the parent material inhibits development of sufficiently fine soil to support it. Where soils are more favorable, the Douglasfir trees grow so close together that the pines cannot reproduce under them and are, therefore, eventually excluded.

\section{d. Ponderosa Pine Stand Complex}

This complex of stand-types is described above in the lower montane section. In the upper montane, stands of this complex occur as the following types of climaxes: a topoedaphic climax on deep soils on the lower part of south-facing slopes, an edaphic climax on unusually coarse soils on north exposures and ridgetops, and a topographic climax on unusually hot and dry slopes. In some habitats, the trees grow tall and are separated enough to permit grasses to form a continuous ground cover. An example of this type, which also contains an abundance of Rhus trilobata Nutt. lies below stand B-3.

\section{e. Limber Pine Stand-Type}

Limber pine may grow scattered with other forest trees, but it never develops vigorously in competition with the other species. Wherever the habitat becomes too severe for the other species, because of strong winds and/or coarse soil, however, limber pine is left to grow alone, and in such sites it forms a neat and distinctive stand. The individual trees are not as narrowcrowned and spire-shaped as most of the evergreen trees in our arca. The trunk usually is free of branches for several feet above the ground, and after the first branch departs from the trunk, there is a tendency for a loss of dominance by the original leader. Consequently, the upper crown of the trec resembles the fingers of a hand with an abundance of large branches all growing upward. This broad crown makes this stand-type conspicuous in the landscape. In more mesic sites, limber pine stands will be replaced by other stands and are, therefore, successional. In severe habitats, it persists as a topographic or a topoedaphic climax.

\section{f. Aspen Stand Complex}

The aspen stand-type is distinctive in the Front Range because aspen is the only broad-leaved tree to form extensive stands on the upland. Although aspen usually is thought of as a moisture-loving species, there are ecotypes in our area that can tolerate severe soil drought; they are dwarfed, scrubby, and short-lived individuals, but aspen none the less. They form a distinctive stand-type on coarse soil of certain ridge-top sites. In more mesic sites, young aspen groves are often very dense, but they open up as the stand matures. Even in the more dense groves, however, sufficient light penetrates to the 
forest floor to permit the development of an abundance of herbs and shrubs. Arctostaphylos grows very vigorously in this stand as does the common juniper. Many grasses and colorful flowering plants form a ground cover with the creeping shrubs. The humus layer in aspen stands is much deeper than under evergreen trees.

Most aspen groves contain scedlings or saplings of some coniferous species (Plate 3A). In the upper montane, Douglasfir, ponderosa pine, and lodgepole pine can reproduce under aspen, whereas aspen is unable to reproduce in its own shade. Consequently, aspen is eventually reduced to only a few dwarfed individuals in a coniferous stand. The roots of these inconspicuous scrubby aspen often survive fires and other disturbances and produce an abundance of "sucker shoots" that pioneer the reforestation of the site. Aspen, then, is usually a successional stand-type. There is some evidence, however, that it is climax in certain small mesic sites and as a narrow stand between gymnosperms and moist meadows in the montane and a bit higher.

\section{g. Lodgepole Pine Stand-Type}

The character of lodgepole pine stands varies with their age. Young stands are almost impenetrable; the slender trees grow so close together that one is often forced to crawl in order to get through the forest. There are literally no shrubs or herbs in many acres of this stand-type. As the stand matures, many trees die, and this results in a gradual opening up of the forest. Eventually ponderosa pine and Douglasfir seedlings become established under the lodgepoles. Since the latter species is less tolerant of shade, it cannot produce saplings that can replace the old lodgepoles when they die. Consequently, ponderosa pine and/or Douglasfir eventually replace the lodgepole. The lodgepole pine stand-type is, therefore, a successional ecosystem in the Front Range (Clements, 1910). It occurs on all types of substrata but is limited to the more mesic north exposure at lower elevations. It rarely occurs below an elevation of 8,500 feet.

Lodgepole pine stands and aspen stands are also common in the next higher climax region, the subalpine forest. Subordinate species and tree reproduction can usually be found in or near a given stand to indicate the region to which it belongs.

\section{h. Valley-Floor Stand-Types}

Several types of stands grow on valley floors, varying, apparently, with changes in soil texture and moisture. Most of them have been disturbed by man or stock; I have not studied any of them in detail.

Cottomwood Stand-Type: Cottonwood stands dominated by Populus angusti- 
folia occur along streams and moist hollows where the water table is high. Most of the current stands have been disturbed and invaded by a variety of species, including all of the trees that grow in the upper montane and some from the subalpine. A mature stand of this type is a soil climax.

Willow-Alder-Birch Stand Complex: This complex of stand-types occurs on river banks and sometimes spreads into extensive thickets where the water table is high, in shallow valleys and hollows.

Dry Montane Grassland Complex: This complex has stands similar to those of the lower montane, but they are dominated by different species and are less common and smaller (Ramaley 1910, 1915, 1916, 1916a and 1919a). They are soil climaxes throughout the upper montane. In some sites they may be biotic climaxes perpetuated by grazing or occasional attempts at agriculture. Any disturbance that inhibits germination and establishment of trees tends to support continuation of this type.

B-4 Stand is in the dry montane grass complex. It is situated at an elevation of 8,200 feet near the eastern limit of a broad glaciated valley within a few hundred yards of the lower limit of Pleistocene glaciation. The glacial parent material is coarse, and the strong westerly winds have a clear sweep of the stand. Since the stand has been recently disturbed by brush-clearing operations and summer grazing by cattle, no quadrat data were gathered. The species presence list is given in Appendix $\mathbf{I}$.

The data collected at the B-4 environment-measurement station (Appendix II) are representative of the external stand environment of most of the valleyfloor stand-types described above. 13-4 soil data are given in Table 7. Air temperature was from $2^{\circ}$ to $13^{\circ}$ cooler at $\mathrm{B}-4$ than at $\mathrm{B}-1$, depending on the feature being compared (Table 11). The $13^{\circ}$ difference in minimum temperature and the $25 \%$ shorter freeze-free period at B-4 are results of cold-air drainage at the valley site. B-4 had 3 inches less precipitation than B-1. This may not be significant; it could result from the greater amounts of wind at B-4, or it might reflect an unusual distribution of storms. It is possible, however, that this is a real and significant difference. Many years of observations of the behavior of storms in the Front Range have led me to conclude that there is an altitudinal belt at the west margin of the Rocky Mountain surface that is drier than the adjoining country both to the east and west. This belt is often not reached by Pacific storms moving eastward and Gulf storms moving westward. B-4 resembles B-1 in soil temperature and relative humidity, but B-1 had somewhat higher soil moisture.

Wet Meadow Stand Complex: Stands of this complex occur around ponds and in hollows where the water table is high. I have not studied them, but several types are described by Ramaley in his 1919 paper. 


\section{Thy Slbalpine Forest Climax Region}

\section{REGIONAL CHARACTERISTICS}

Geography and Geology: The subalpine forest lies above the upper montane and below the alpine tundra. It has been called the subalpine zone and the spruce-fir climax by other authors. The transition region between the subalpine and alpine regions is the familiar "timberline" or "treelimit". On the east slope of the Front Range, the subalpine region lies between approximately 9,300 and 11,000 feet elevation, cutting across the lowermost of the conspicuous glacial cirques.

This region embraces parts of both the Rocky Mountain and the Flattop erosion surfaces and some areas that do not clearly belong to either surface. Regional altitude increases rapidly from east to west. Ridgetops have steep gradients, while the valley floors usually are climbing at a lower gradient because glaciers scoured them in their upper reaches and deposited rock debris in them at lower elevations. One consequence of this is that valleys become deeper and deeper as the divide is approached and their slopes become sheer cliffs. Most valleys terminate in the cliffs of glacial cirques up in the alpine region.

Ice-cap glaciers of pre-Wisconsin time spread down to an clevation of about 11,800 feet on Niwot Ridge leaving a thin cover of glacial till with an occasional large boulder, but this ice did not reach down into the subalpine. Wisconsin glaciers were confined to valleys; they moved down varying distances and then retreated unknown distances, perhaps disappearing entirely for an interval. During post-Wisconsin time, glaciers that persisted or were reborn moved only short distances. The pre-glacial valleys often widen out abruptly at about 10,500 feet elevation. As glaciers entered the wider valley, they usually did not spread out and fill the entire valley; instead, they maintained the dimensions of the upper valley and produced giant lateral moraines that dammed up drainage from adjacent slopes and lateral valleys and produced extensive boggy and marshy areas in the subalpine in sites that would otherwise have been relatively dry. Extensive areas, such as most of the top, the upper slopes, and the east end of Niwot Ridge, were never touched by Wisconsin and later ice and perhaps escaped even earlier glaciations. This circumstance has had profound effects on the region's ccology because it gave long geologic intervals for the weathering of bedrock into a deep mantle.

Glacial moraines of several ages and many sizes are common in valleys. The youngest deposits, probably only a few hundred years old, lack soil profiles and support only a sparse cover of pioneer plants. Some of the oldest 
deposits, on the other hand, have well-developed profiles and are completely covered with vegetation.

Lakes are common in the subalpine; permanent ones are usually in valleys where glaciers gouged basins or left depressions in morainal deposits. Many permanent and intermittent ponds lie in small pockets on the moraines and on the flat surface of solifluction terraces.

Igneous and metamorphic rocks form bedrock. Landslides are rare today, in spite of the presence of many precipitous slopes. Snow slides, originating above timberline, occasionally reach the forest in other parts of the Range, but they are rare in Boulder County.

Soils: Soils are highly variable, ranging from coarse and bouldery to clay or peat. Well-drained soils are usually sandy loams (Table 13). Profiles are fairly well developed on unglaciated, stable parent material and on the older glacial parent material. The best-developed profiles have several inches of litter and mulch, a grey, somewhat leached horizon, and a yellowish concentration horizon. These are podzolic soils. Soil ice is common during the winter in sites kept snow-free by wind, but it is rare under trees and in areas where snow accumulates to depths of several feet.

Climate: The climate is cool and moist. Summers are short, cool, and moist with many late-lying snow banks and frequent thunderstorms; hot days are infrequent, whereas cool, wet intervals of a few days are common. Autumn is dry, usually cool during the day, and often cold at night; at least one snow storm usually initiates or breaks into the Indian summer weather, and on

Table 13. Subalpine Soils Data

\begin{tabular}{|c|c|c|c|c|c|c|}
\hline \multirow{3}{*}{ Stand } & \multirow{3}{*}{ Deptb, inches } & \multirow{3}{*}{ Soil Type } & \multicolumn{4}{|c|}{ Mechanical Analysis: Particle Size in mm. } \\
\hline & & & \multirow{2}{*}{$\%$ over 2} & \multicolumn{3}{|c|}{ Percentages of Fraction under 2} \\
\hline & & & & $2-0,05$ & $0.05-0.002$ & $\begin{array}{l}\text { below } \\
0.002\end{array}$ \\
\hline $\mathrm{C}-1$ & $\begin{array}{l}0-6 \\
6-12\end{array}$ & $\begin{array}{l}\text { Sandy loam } \\
\text { Sandy clay-loam }\end{array}$ & $\begin{array}{l}18 \\
42\end{array}$ & $\begin{array}{l}63 \\
60\end{array}$ & $\begin{array}{l}24 \\
19\end{array}$ & $\begin{array}{l}12 \\
20\end{array}$ \\
\hline $\mathrm{C}-2$ & $\begin{array}{l}0-6 \\
6-12\end{array}$ & $\begin{array}{l}\text { Sandy loam } \\
\text { Sandy loam }\end{array}$ & $\begin{array}{l}19 \\
26\end{array}$ & $\begin{array}{l}68 \\
59\end{array}$ & $\begin{array}{l}24 \\
24\end{array}$ & $\begin{array}{r}9 \\
16\end{array}$ \\
\hline $\mathrm{C}-3$ & $\begin{array}{l}0-6 \\
6-12\end{array}$ & $\begin{array}{l}\text { Sandy loam } \\
\text { Sandy loam }\end{array}$ & $\begin{array}{l}26 \\
32\end{array}$ & $\begin{array}{l}68 \\
65\end{array}$ & $\begin{array}{l}21 \\
23\end{array}$ & $\begin{array}{l}11 \\
12\end{array}$ \\
\hline $\mathrm{C}-4$ & $\begin{array}{l}0-6 \\
6-12\end{array}$ & $\begin{array}{l}\text { Sandy loam } \\
\text { Sandy loam }\end{array}$ & $\begin{array}{l}32 \\
48\end{array}$ & $\begin{array}{l}69 \\
64\end{array}$ & $\begin{array}{l}19 \\
21\end{array}$ & $\begin{array}{l}12 \\
15\end{array}$ \\
\hline
\end{tabular}


rare occasions it delivers several feet of snow; there are many intervals of clear, calm, really hot days and cool nights; winds are strong at times. The winter is long, cold, windy, and usually has an abundance of snow. The spring is short, cool, and wet; in most years, at least one spring snow storm yields 2 or more fect of snow.

Winds at all seasons are from the west when strong. East winds are gentle, often producing heavy fog in any season. Significant amounts of precipitation come from both the east and the west. Snow strongly influences the character and distribution of several types of stands in the subalpine. In general, snow accumulates to much greater depths and remains on the ground for much longer periods in the subalpine than in the montane regions. Within the subalpine, there is great variation in the depth and duration of the snow cover. In all forest stands except limber pine, there is snow on the ground most of the winter, and it reaches several feet in depth even where there is no extra accumulation from wind transportation. Small clearings only a few feet across receive extra snow by wind transport from that which first settles on the branches of trees in the immediate vicinity. Deep snow drifts develop wherever a clearing, meadow, low shrub stand, or frozen lake provides a "source area" of snow that the wind can pick up, and a group of trees or a topographic break serves as a "baffle area" that slows the wind down and forces it to deposit snow in an "accumulation area". These 3 areas grade into one another like most natural areas. The deepest and largest accumulations of snow occur in the upper part of the subalpine where great expanses of tundra serve as source areas for great volumes of snow and topographic breaks or tree stands provide baffles. Climax wet meadows produced by snow accumulation occupy these sites where snow accumulates to depths of many feet and persists well into the summer.

The details on the subalpine regional environment are given in the Stand C-1 table in Appendix II.

Forest fires, starting most often in the montane, have moved up-slope in their characteristic behavior and cut wide swaths in the spruce-fir forest, often extending for miles along slopes, and sometimes seruding a narrow tongue upward to timberline and above. Evidence of these fires remains for hundreds of years, even after complete revegetation has taken place, because lodgepole pine and aspen, which pioneer the burn sites, contrast sharply with the remnants of spruce-fir forest.

Vegetation: One of the most homogeneous, simple, and continuous vegetation types of the Front Range occurs at intermediate altitudes in this region, while higher and lower elevations support complex and heterogeneous vegetation. In the central area, dense evergreen forest of spire-crowned spruce and fir trees stretch across valleys and over ridges for many miles, broken only by 
stands of broad-erowned limber pine on the more exposed ridgetops; even differences in exposure produce no obvious changes in the vegetation. This vegetation is often truly primeval forest that has changed very little for many hundreds, if not thousands, of years. It occurs where remoteness, rough terrain, bouldery substratum, and relatively low timber values have discouraged exploitation, and relatively moist environments have kept fires to a minimum. Wet meadows and moist shrub stands occur in areas of high water table. Dry meadows or "alpine parks" occur on valley slopes and ridges.

In contrast, the upper part of the subalpine is ragged due to variations in soil parent material, topography, and patterns of heavy snow accumulation. Wet meadows are common. The lower part is even more heterogeneous because repeated disturbance and fires have destroyed the more stable sprucefir forests, or have prevented them from ever developing. Lodgepole pine and aspen, separately or in combination, have reforested these areas. Where fires have been repeated again and again over large areas for several hundred years, spruce and fir may be entirely absent. In most stands, however, the presence of some subordinate plant, like Vaccinium myrtillus L., which has an ccological amplitude similar to spruce and fir, indicates that these latter species will eventually replace the pioneer trees if fires do not recur. In many lodgepole and aspen stands, spruce and fir saplings are already present.

\section{THE MAJOR STAND-TYPES}

\section{a. Spruce-Fir Stand-Type}

\section{(1) General Features}

Stands of Engelmann spruce and subalpine fir (Plate 3B) are the most magnificent forests in this mountain area. The trees are small in comparison with the trees of the wetter regions of northwestern U. S. mountains, but compared to those in our own montane, they are large. Some are over 3 feet in diameter and 100 feet tall. They grow close together with their spire-shaped crowns almost touching. In spite of the dense shade, Vaccinium myrtillus or $V$. scoparius Leiberg. form an almost continuous ground cover about 12 inches high. Several herbs often rise above the shrubs, but they occur only sporadically. Rams horn lousewort (Pedicularis racemosa Dougl.), a graceful plant with pure white petals curved like horns, is the most striking of these herbs. Spruce and fir seedlings and suppressed saplings are abundant in all mature stands.

Many generations of trees have lived, died, and fallen over in these longpersisting stands, and wind-throw of both living and dead trees is common. The resulting tangle of stumps and fallen logs in all stages of decay, often 
with no systematic orientation, makes passage through these stands a tedious and tiresome activity.

The old spruce-fir stands are relatively stable in character, changing very little from century to century. As the older trees scattered through the stand die, seedlings or suppressed saplings grow rapidly to form replacements that keep the stand relatively closed. No other tree species that grow in this region can reproduce in the dense shade of the spruce-fir stand. Individual trees grow, die, and decay; blueberry bushes are dense in one area this year and in another area 100 years later; soil moisture levels fluctuate between the upper and lower limits of the range of this factor from year to year; but the character of the stand as a whole remains relatively constant. These stands have reached this relative equilibrium, and achieved this "climax status", because their environment has always inhibited fires and discouraged exploitation; consequently, there has been adequate time for ecosystem processes to produce the relatively stable type of ecological unit. Moisture, the factor that inhibits fires, reaches these stands as "direct" precipitation, and also as "secondary" precipitation in the form of snow blown down into the stands from the treeless tundra of higher elevations. Even in dry years, this secondary precipitation is rather reliable. Snow banks and rivulets of snow-melt water are common in these stands far into the summer. Their soil does dry out in the late summer and may be very dry in the fall, but by these seasons the lightning of thunder storms that ignites many of the mountain fires is rare.

There are many relatively stable spruce-fir stands on slopes in the subalpine region. These are topographic climaxes. At higher elevations spruce and fir form successional stands on sites where fires destroyed one stand and there was no source of lodgepole pine seed nor of aspen suckers.

\section{(2) Detailed Study Stands}

There were no old spruce-fir stands in our region that were located in sites that fulfilled the requirements of the project design. Consequentiy, we did not study the vegetation of this type intensively. At a later date, Albert Johnson (1956) studied several stands in the Silver Lake Valley, where we still had a station in operation. His Stand 3-B is a mature spruce-fir unit located where the valley is a mile wide and on a surface somewhat above the bottom of the main valley. Quadrat data in Table 14 are taken from Johnson's thesis.

The great density of tree trunks in the spruce-fir stand and the paucity of shrubs and herbs contrast strikingly with the more open climax stands of the montane. This is a rather drab stand-type that is monotonously uniform for long distances, especially in the winter when snow covers even the slight heterogeneity produced by patchiness in the distribution of the few common shrubs and herbs. Johnson's quadrats included only 3 species in the lower 
TABLE 14. Silver Lake Spruce-Fir Stand Vegetation Data (from Johnson 1956)

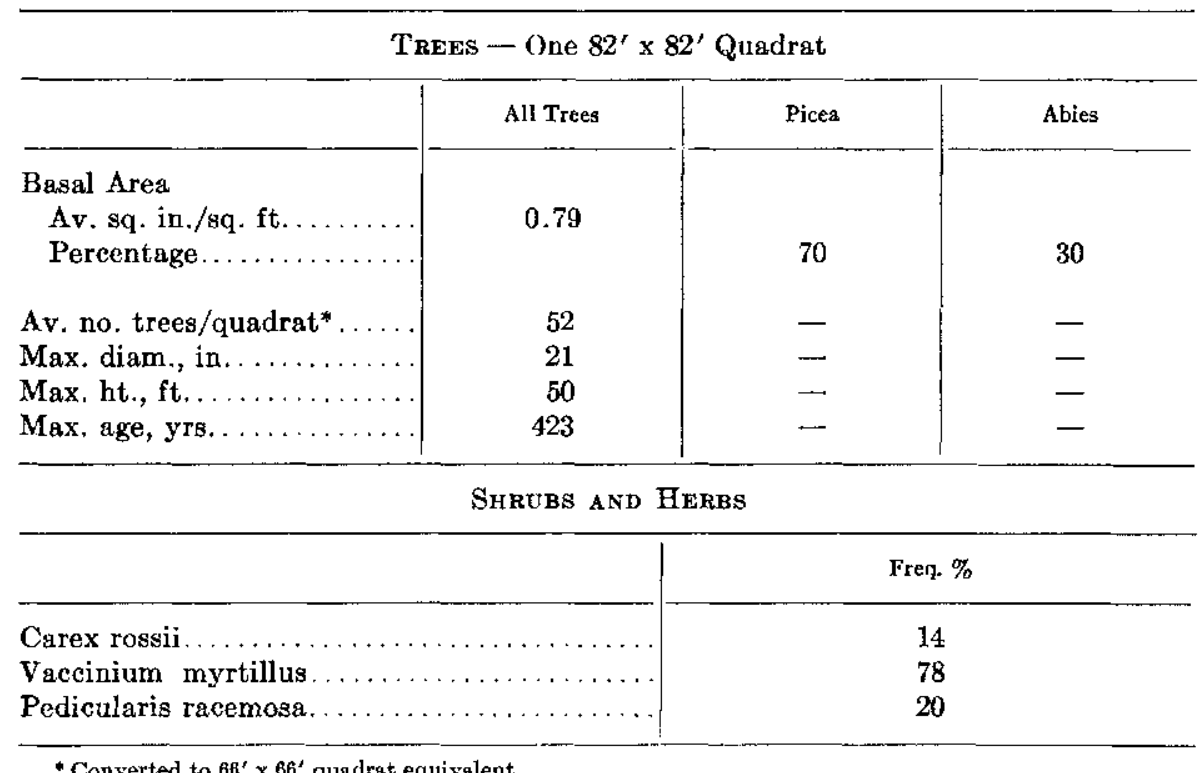

'Converted to $66^{\prime} \times 66^{\prime}$ quadrat equivalent.

synusia. Some individuals of Arnica cordifolia Hook., Pyrola spp., and Rosa acicularis Lindl. turn up in most samples of this stand-type.

The external stand environment of Johnson's stand is probably intermediate between that of our stations $\mathrm{C}-1$ and C-4 (Appendix II). It is less exposed and somewhat higher than the lakeside site of $\mathrm{C}-4$ and, consequently, is less windy and less influenced by cold-air drainage.

Tree ages indieate that a small amount of selective lumbering is the only disturbance this stand has experienced in about 500 years, and no fires have taken place in that interval. It is near, therefore, to the status of a true climax, perhaps as near as local stands ever get. Its topographic setting prevents it from being a perfect climatic climax, but the valley is so broad and shallow in this vicinity that topographic influences are at a minimum. For most purposes, this can be considered a climatic-climax unit.

\section{b. Lodgepole Pine Stand-Type}

\section{(1) General Features}

Subalpine slopes are often broken by a narrow, sinuous line that separates a yellowish-green, smooth-textured lodgepole pine forest from a taller sprucefir forest of darker green color and more ragged texture. Fire and/or lumber- 
ing followed by reforestation alcount for this pattern. Crandall (1897), Clements (1910), and Stahelin (1943) have all described research on this stand-type. Both Johnson (1956) and Douglas (1954) describe some of these stands in our research area.

lodgepole pine stands of the subalpine resemble those of the montane described above, but the species of shrubs and the species of trees that reproduce under the lodgepoles differ between the two regions. In the subalpine, blueberries form the ground cover with frequent additions of mosses and lichens, and most tree seedlings are spruce and fir. The stands are of many different ages. Young stands are almost impenetrable and include very few species other than lodgepole pine. As the stands get progressively older, the percentage of spruce and fir increases steadily until eventually a spruce-fir stand with a few old relic lodgepoles has developed.

\section{(2) Detailed Study Stands}

Several young lodgepole pine stands located at an elevation of 10,000 feet on different exposures were studied in our investigations. The study area includes the site of "Hill's Mill", which was located just above Science Lodge and operated until about 1900.

Stand C-1C was on the rather flat surface that extends for about 225 yards on the top of Hill's Mill ridge. The ground slopes southeastward slightly in the stand. The parent material is a very old glacial till much modified by wind and water transport and deposition. The soil is a podzol with an orange-brown colored $\mathrm{B}$ horizon. The tree synusia contains only lodgepole pine ('Table 15) with individual trees so close together that branches interlace. The trees range in height from 4 to 32 feet and in age from 20 to 37 years. Stahelin (1943) found that it usually takes about 25 years for this species to achicve a completely closed stand. The smaller individuals are suppressed trees, not young ones. Competition is severe in these stands; many of the smaller trees are already dead and many more will die as the stand matures.

Table 15 gives the frequency of shrubs and herbs in Stand C-1C. Vaccinium was the only subordinate species with a significant amount of cover.

Environment-measurement station C-1 was located in a clearing produced in the days of the lumbering operation and not yet reforested. The annual summary for this station is given in Appendix II; soil data are given in Table 13. It is interesting to compare the environment factors at this stand with those of stand B-1 since the two are in similar topographic situations and represent moderate conditions in two adjacent climax regions. Comparative data are in Table 9 . The stations are separated horizontally by about 6 miles and vertically by 1,500 feet. C-1 is distinctly cooler than B-1. Air temperatures 
- Table 15. C-1C Lodgepole Pine Stand Vegetation Data

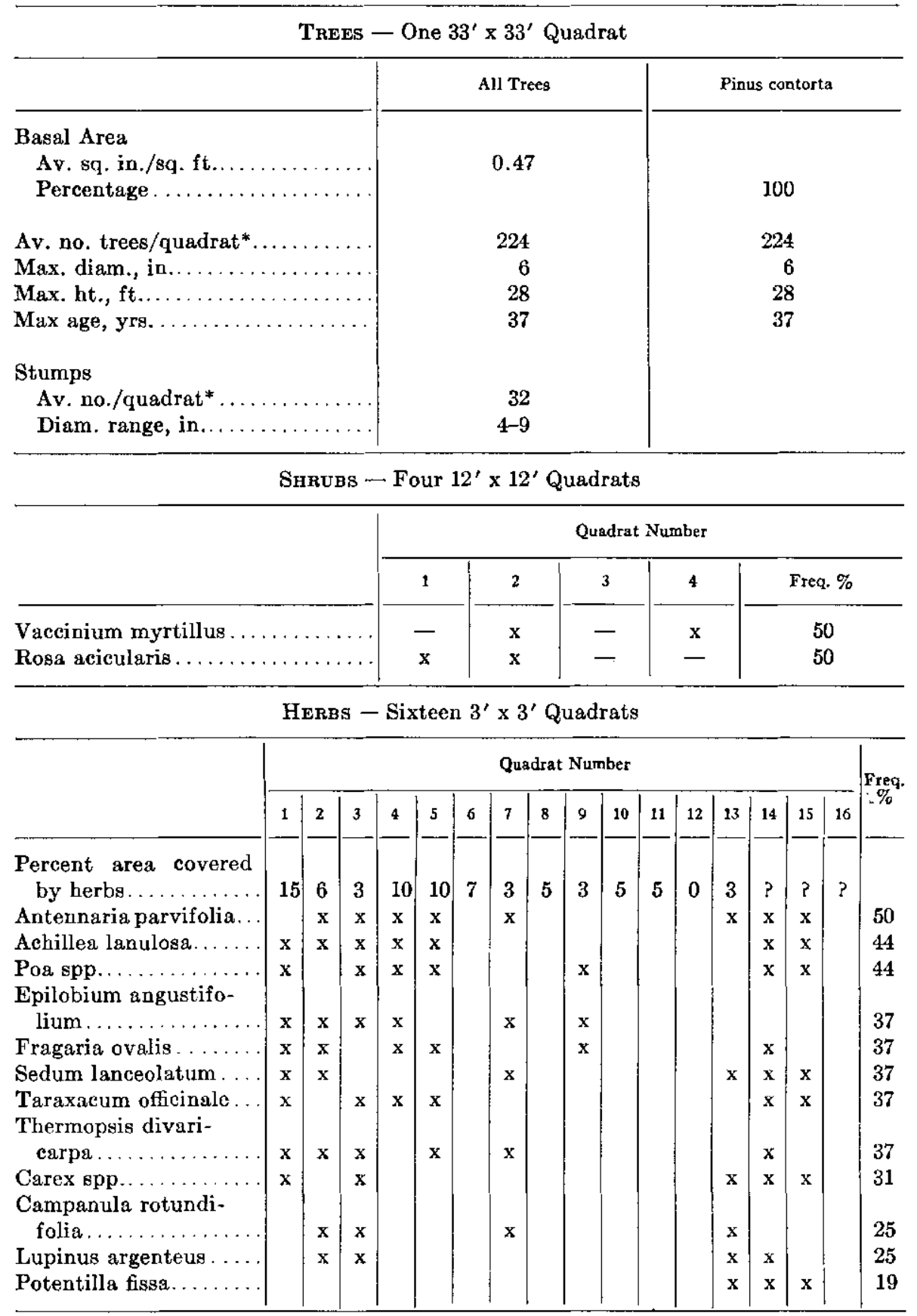

' Converted to $66^{\prime}$ x $66^{\prime}$ quadrat equivalent. 
were generally $6^{\circ}$ to $8^{\circ}$ lower, while there was $19^{\circ}$ difference in the absolute maximum. Soil temperatures were lower by $2^{\circ}$ to $4^{\circ}$ except for the maximum at the $6^{\prime \prime}$ level, which was the same at $\mathrm{C}-1$ and B-1. The last freeze at B-1 was on 26 May and at C-1 on 7 June, but the first one in the fall hit both stands at the same time (3 September) so that there was only 13 days' difference in the length of the summer frecze-free period. There was $50 \%$ more wind, $25 \%$ more precipitation, and the mean soil moisture was $3 \%$ more at $\mathrm{C}-1$. The snow cover reached a maximum depth of 60 inches at C-1 as compared to only 11 inches at B-1, and there was snow on the ground for 2 months longer in the former stand. The average relative humidity for the year was about the same at the two stands, but it was distinctly higher at C-1 during July and August. These conspicuous differences between the subalpine and upper montane are especially interesting when it is remembered that the lower and upper montane were quite similar. The data reveal that there is a greater quantitative difference between the subalpine and the upper montane than there is between the upper and lower montane.

Stand C-1 is successional to spruce and fir. There were no seedlings of these species in the stand, but it is obvious from the regional ecology that these species will eventually replace the lodgepole. One near-by indicator of this trend is a mixed stand of large lodgepole, spruce, fir, and limber pine a few hundred yards south of $\mathrm{C}-1$ near the top of the moraine. This mixed stand is much older than $\mathrm{C}-1 \mathrm{C}$ and is obviously an intermediate type in the regional successional sequence from lodgepole pine to spruce and fir.

Stand C-3A: Lodgepole pine stand C-3A, located on the south-facing slope $(14 \%)$ of Hill's Mill Ridge, was also studied in detail. It is a somewhat older stand, and its trees are larger and farther apart than in the other two subalpine lodgepole stands. Table 16 gives the quantitative data on the vegetation. Thermopsis, Arnica, and Lupinus occur in the larger openings of this stand, although they were not in any of the quadrat samples.

The external stand environment of C-3A was measured in a clearing just up-slope from the stand; an annual summary is in Appendix II; soil data are in Table 13. The C-3 maximum temperature, in both air and soil, was higher than the same feature at $\mathrm{C}-1$, but other temperature features were not significantly different (Table 17). There was distinetly less wind at C-3, and, partly as a consequence of this fact, it received more precipitation in its rain gauge. Since the C-3 site is on a slope, wind crossing the ridge breaks up into eddies and slows down, and its capacity to carry snow is thus diminished. The correlation between wind and precipitation is demonstrated by the data; precipitation was essentially the same at the two stations except for the months of December through March, the period of strong westerly winds. 
TABle 16. C-\$A Lodgepole Pine Stand Vegetation Data

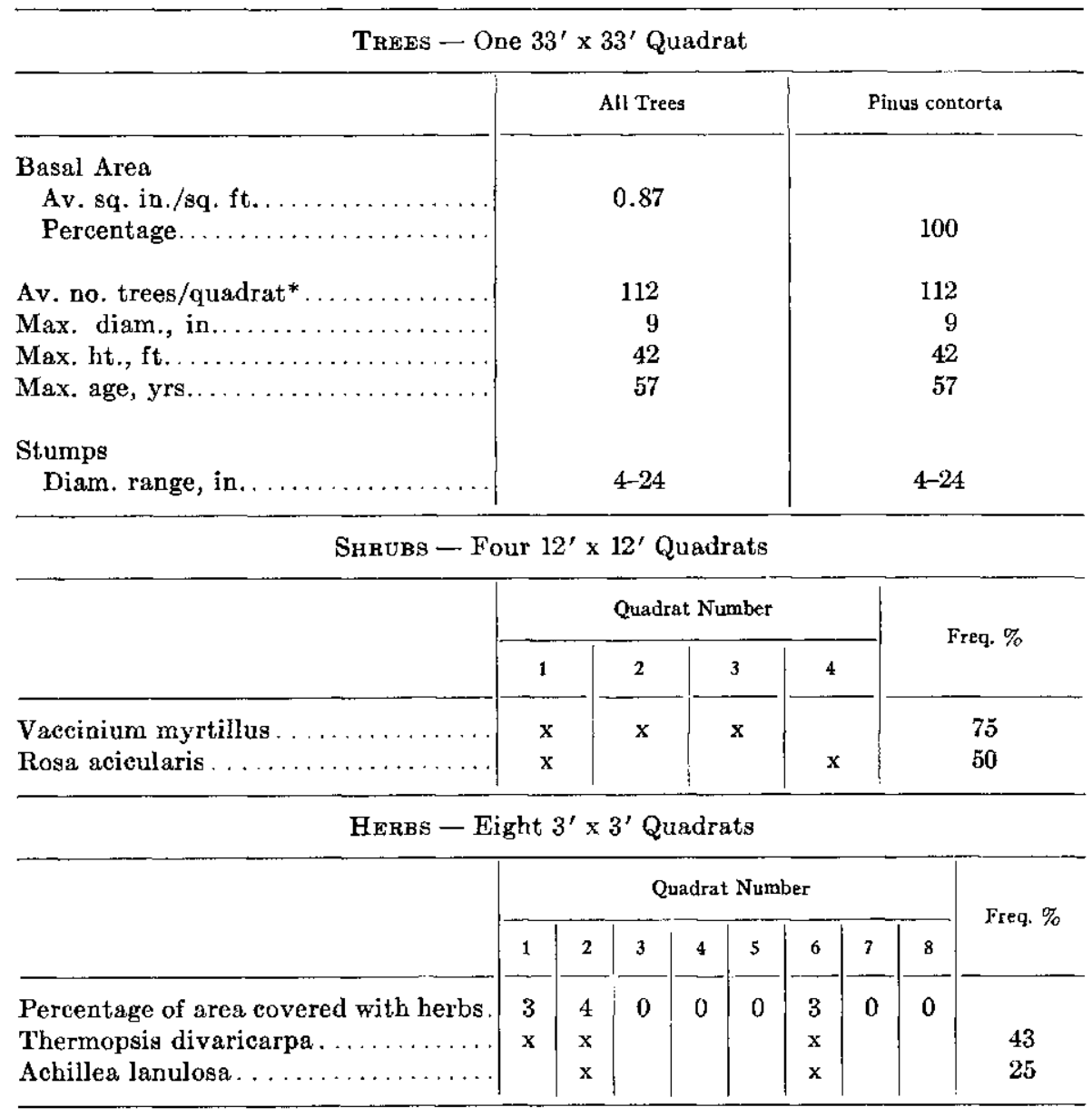

- Converted to $66^{\prime} \times 66^{\prime}$ quadrat equivalent.

Snow left the C-3 stand a month earlier than it did at C-1, having reached a maximum depth of 60 inches at the latter and only 42 inches at the slope station. Relative humidity was the same at the two stations.

Stand C-2A: The third lodgepole pine stand studied in detail was C-2A located on the north-facing slope (15\%) of Hill's Mill Ridge. Quadrat data on its vegetation are given in Table 18 . This stand is the same age as $\mathrm{C}-1 \mathrm{C}$. It contains a few spruce and fir that came up along with the pioncering pines, and one quadrat contained some fir seedlings. Its external environment was 
TABLE 17. Comparison of Stands in the Subalpine Climax Region

\begin{tabular}{|c|c|c|c|c|}
\hline & \multicolumn{4}{|c|}{ Stands } \\
\hline & $\begin{array}{l}\text { C-3A Lodgepole } \\
\text { Pine, C-3B } \\
\text { Aspen }\end{array}$ & $\begin{array}{l}\text { C-1C Lodgepole } \\
\text { Pine, C-1D } \\
\text { Aspen, C-1 } \\
\text { Limber Pine }\end{array}$ & $\begin{array}{c}\text { C-2A Lodgepolt } \\
\text { Pine, C-2B } \\
\text { Aspen }\end{array}$ & $\begin{array}{c}\text { C-4 Valley } \\
\text { Floor Stands }\end{array}$ \\
\hline Altitude, ft.. & 10,000 & 10,000 & 10,000 & 10,200 \\
\hline Exposure. . & S-facing & Ridge top & $N$-facing & Valley floor \\
\hline $\begin{array}{l}\text { Yearly Features of Environment } \\
\text { Factors: } \\
\text { Air temperature degrees } F \text {. }\end{array}$ & & & & \\
\hline 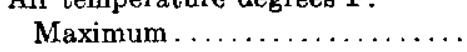 & 80 & 75 & 79 & 73 \\
\hline Mean Max................. & 48 & 44 & 46 & 42 \\
\hline Minimum $\ldots \ldots \ldots \ldots \ldots \ldots$ & -13 & -14 & -15 & -21 \\
\hline Mean Min................. & 25 & 24 & 24 & 23 \\
\hline Mean $\ldots \ldots \ldots \ldots \ldots \ldots \ldots$ & 36 & 34 & 35 & 32 \\
\hline Longest freeze-free period, days. . & 87 & 87 & 85 & 55 \\
\hline $\begin{array}{l}\text { Soil temperature, degrees } F \text {. } \\
6 \text { inch depth }\end{array}$ & & & & \\
\hline Maximum $\ldots \ldots \ldots \ldots$ & 76 & 72 & 72 & 70 \\
\hline Mean Max.............. & 47 & 46 & 42 & 43 \\
\hline Minimum $\ldots \ldots \ldots \ldots \ldots \ldots$ & 18 & 19 & 20 & 16 \\
\hline Mean Min. . . . . . . . . . . & 36 & 34 & 34 & 33 \\
\hline Mean...... & 42 & 40 & 38 & 38 \\
\hline 12 inch depth & & & & \\
\hline 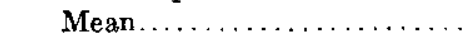 & 40 & 40 & 38 & 38 \\
\hline Wind, total miles . . . . . . . . & 71,184 & 91,276 & 65,762 & 115,323 \\
\hline Velocity, $\operatorname{mph} \ldots \ldots \ldots \ldots \ldots$ & 8 & 10 & 8 & 13 \\
\hline Precipitation, in............. & 31 & 26 & 30 & 26 \\
\hline $\begin{array}{l}\text { Maximum snow depth, in. (with } \\
\text { min. of drifting } \ldots \ldots \ldots \ldots\end{array}$ & 42 & 60 & 59 & 28 \\
\hline Soil moisture, \% dry wt. & & & & \\
\hline $5-7^{\prime \prime}$ depth, mean...... & 9 & 10 & 10 & 10 \\
\hline $11-13^{\prime \prime}$ depth, mean ............. & 8 & 11 & 10 & 10 \\
\hline Mean relative bumidity......... & 61 & 62 & 61 & 65 \\
\hline
\end{tabular}

*This site was 200 feet higher and 2 milea closer to the Divide than the other three "C"

measured in station C-2, located in a clearing just up-slope and across an old logging road from the stand. The annual summary for this station is in Appendix II; soil data are in Table 13 . The C-2 maximum air temperature for the year appears anomalous because it was $4^{\circ} \mathrm{F}$ higher than the same feature on the ridge top and only $1^{\circ}$ lower than the maximum on the south- 
Table 18. C-ZA Lodgepole Pine Stand Vegetation Data

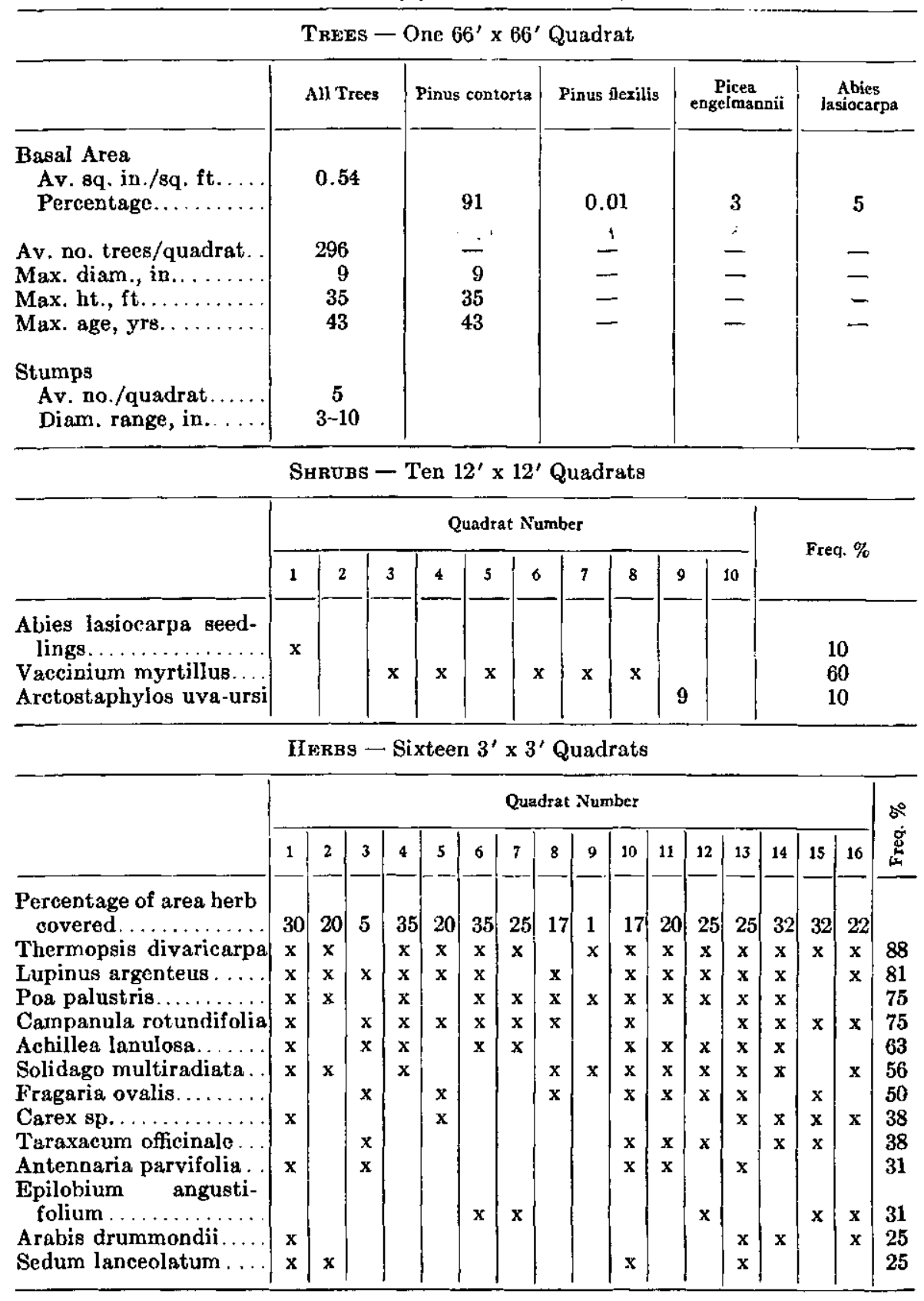


facing slope at C-3. This unexpected relationship appears to result from local air circulation that carries unusually warm air to the north-facing slope site.

The environment of the stands on the two slopes of Hill's Mill Ridge are similar in air temperature, rarely differing by more than $2^{\circ}$ (Table 17). The soil temperatures at C-3 (south-facing slope) reached higher maximums, but minimums were close together. C-3 also had a freeze-free period 2 days longer than $\mathrm{C}-2$ because it escaped the first fall freeze. There was no difference in precipitation and relative humidity. C-2 had a little higher soil moisture and about $8 \%$ less wind than $\mathrm{C}-3$. The snow cover reached a depth of 59 inches at C-2 and remained on the ground longer; there were only 3 months without some snow cover.

\section{c. Aspen Stand-Type}

\section{(1) General Features}

Aspen stands of the subalpine contain subordinate species that are different from those in montane aspen stands described in the previous section. Subalpine aspen stands are usually suecessional to spruce-fir, but some are successional to lodgepole pine, and a few may be climax stands. Most of the subalpine aspen stands are small, a fraction of an acre to a few acres in extent. This small size is probably related to the fact that this species is unable to reproduce by seed in the Front Range, and seedlings of other species become established on disturbed sites before the root suckers of aspen can gain dominance.

The interrelations and comparisons of lodgepole stands and aspen stands in both the upper montane and subalpine have not been worked out satisfactorily. It is often stated that aspen reforests moist sites and lodgepole pine reforests dry sites, but there is no evidence in our area to support this belief. Aspen does definitely grow more vigorously in moist than in dry sites, but so does lodgepole; lodgepole does grow on rather dry sites, but so does aspen. It appears that the environment-amplitudes of the two species are very similar, and that availability of seed or suckers controls the selection of one or the other species each time a site becomes available for colonization. Lodgepole seeds, produced in superabundance, and often (but not exclusively) held in their cones until a fire forces them open, frequently cover extensive areas with seedlings in only a few years after disturbance. Studies made at Science Lodge in 1947 demonstrated that aspen trees also produce viable seed, but we have no evidence that seedlings are ever established naturally. Vcry few acres of any subalpine stand, however, lack a few straggling sprigs of suppressed aspen. When the over-story trees are removed, the roots of 
these aspen produce many sucker shoots that, along with suckers from their own expanding root system, rapidly cover the disturbed area.

Herbs develop a dense stand on many disturbed sites before lodgepole or aspen can get established. Once well developed, the herbs are resistant to encroachment by lodgepoles because the tree seedlings are in vigorous competition with the herbs. Aspen suckers are more successful in invading these meadows, presumably because they do not have to be self-sufficient; their roots attach them to older shoots from which they obtain nutrients, water, and even food. Many isolated aspen groves are expanding centrifugally into meadows.

The potential capacity of these two stand-types to succeed one another in ecosystem change is significant in the regional ecology. The capacity of lodgepole to succeed aspen is demonstrated by the presence of lodgepole saplings in many aspen stands and large, dead aspen in lodgepole stands. There is no evidence that aspen can develop in a lodgepole stand and eventually replace it.

Another interesting feature of the ecology of these species in Boulder County is their abundance and vigor at different altitudes. Both aspen and lodgepole grow throughout the subalpine, but they are not common in the upper part of this region. Aspen are rare and small above an elevation of about 10,000 feet; lodgepole pines are rare but vigorous where they do occur, up to at least 10,800 feet. The explanation for these characteristics of distribution is not easy to find, and no well-documented analysis of the problem has been published. The basic difficulty is that these trees are successional species, and the absence of a successional species in any given area may be accounted for by either of two possibilities: (1) the area's environment is outside the environment-amplitude of the species, or (2) the area's environment is within the amplitude of the species but it has lost out in competition with other species.

Since some individuals of these species occur all the way up to, and including, the tree-limit region, it is clear that at least some sites throughout the subalpine are within the environment-amplitude of the species. Their sparsity, therefore, is probably related to inability to compete with the climax species and to the occurrence of long intervals without disturbance or fire. It is quite possible that any or all of the following ideas are sound: (1) some types of sites are outside the amplitude of lodgepole pine and aspen; (2) others are within but near the limits of their amplitude while being far from the limits of the amplitude of the climax species, with the result that the climax species do the pioneering and exclude the typical pioneer species; and (3) many disturbed or burned sites would permit vigorous development of lodgepole pine and aspen, but there were no sources of seed or propagules following removal 
of the previous vegetation, while disseminules of the climax species reached the site and were suecessful.

The statement made above that lodgepole pine and aspen both occur in the forest-tundra transition region deserves more comment here. Near the south-east end of Niwot Ridge, there is a dwarfed aspen stand covering several acres of an old burned area. Individual stems are only a few feet tall and growth is slow, but there is no evidence that these "trees" will be destroyed by extremes of the external stand environment. They will apparently persist until climax species crowd them out.

\section{(2) Detailed Study Stands}

Aspen stands were studied in detail on different topographic sites on Hill's Mill Ridge above Science Lodge.

Stand C-1D is south of Station C-1 and southeast of lodgepole pine stand C-1A. It is close to a small creek and may have a higher water table than the pine stand. Table 19 gives data on the vegetation. Seedlings and saplings of lodgepole pine and Engelmann spruce occur in this stand, and limber pine saplings occur in an adjacent aspen stand. This capacity of these gymnosperms to reproduce in an aspen stand while aspen is unable to reproduce in its own shade demonstrates why aspen stands are successional in this region. The stand contains an herb synusia with many species forming a dense cover, a striking contrast to the adjacent lodgepole pine stand's depauperate herb population.

The external stand environment of $\mathrm{C}-1 \mathrm{D}$ is represented by data collected at station C-1. C-1D may be a more mesic site than that of the station, however, due to ground-water movements that produce the small creek.

This is obviously a successional stand. Stump data ('lable 19) show that there was a stand of gymnosperms on this site previous to the lumbering, but we do not know the species composition of that stand. Data on saplings (Table 19) indicate that aspen leads the other trees in frequency of saplings, but this can be misleading in attempts to interpret the future of the stand. The youngest aspen tree is about 20 years old. The aspen "saplings" are actually suppressed sucker shoots, probably all at least 20 years old, which cannot grow any larger in the existing competition. They will all die before developing into trees unless some current over-story individuals die. In the meantime the gymnosperm saplings continue to grow, even under competition with the aspen over-story. It is evident, then, that as time goes on, the gymnosperms will increase and aspen will decrease. The species composition of the next distinct stand-type in the sere is not evident at this time, but regional ecology leaves no doubt that the ultimate stable stand that would develop 
TABLE 19. C-1D Aspen Stand Vegetation Dala

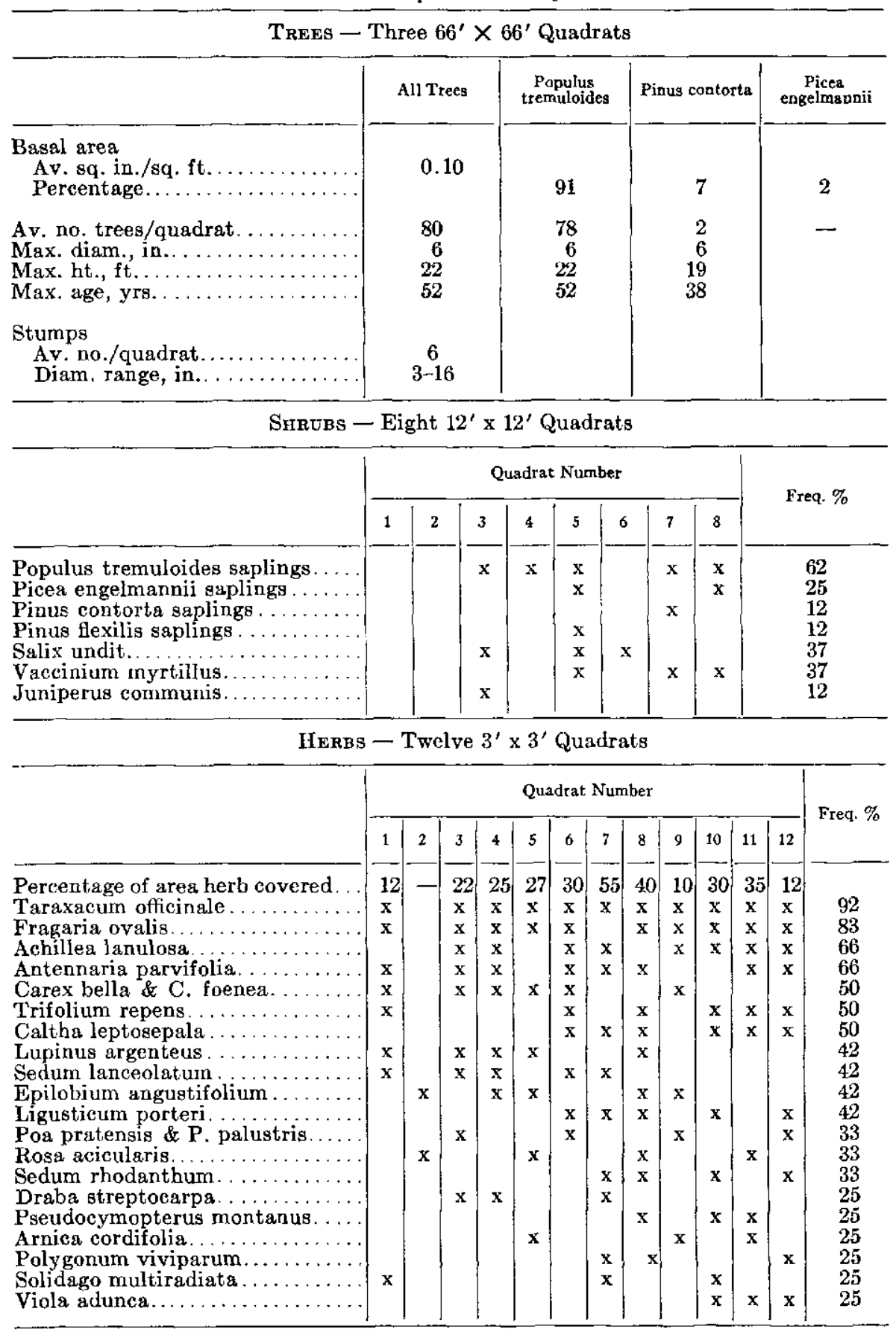

Note: Twenty-eight other apecies present in the quadrats with a frequency of less than 20 per cent are liated in the species list in the Appendix I. 
in the absence of disturbance or fire would be dominated by spruce and fir. Being somewhat more mesic than the average site, the stand would have a larger proportion of fir than the average subalpine climax.

Aspen stand C-3B, (located next to station C-3) on the south-facing slope, contained a fow lodgepole pine trees from the time of its beginning after the last disturbance. In fact, the comparative tree ages (Table 20) suggest that the lodgepole pines got started on this site earlier than aspen, but this may be misleading; the earliest aspen trees may have died. The annual summary for the environment factors measured at C-3 is in Appendix II. The abundance of lodgepole pine seedlings indicates that a stand of this species will eventually replace the aspen, and regional ecology indicates that spruce and fir will subsequently replace the lodgepole pine and produce a climax stand.

Aspen stand C-2B was located on the north-facing slope, northeast of Station C-2 and east of lodgepole pine stand C-2A. It is surrounded by lodgepole stands and contains all ages of individuals of that species. Table 21 gives vegetation data, and an annual summary of the stand's external environment is in Appendix II. It is probably successional to a lodgepole pine stand. Ecosystem change on this site and the adjacent sites now supporting lodgepole pine tends to bring about a convergence toward a single standtype, a spruce-fir climax.

\section{d. Limber Pine Stand-Type}

Limber pine stands are especially conspicuous in the subalpine landscape, even from long distances, because the broad crowns of the limber pines produce a texture that contrasts sharply with that produced by the narrow crowns of spruce, fir, and lodgepole pine. Extensive stands of limber pine are restricted to sites with exceptionally strong winds and/or coarse soil. Small stands, often of only a few trees, occur in micro-sites of a similar nature throughout the subalpine. I have not found a large stand in a site with average or relatively low wind and coarse soil, but some small stands do occur under that combination of environment factors.

All of the limber pine stands in our area are relatively old. The trees are widely spaced and usually have only a short segment of branch-free trunk; it is probable that they have survived because the wide spacing minimized fires and the low branches have discouraged lumbering. The openness of the stand permits free wind movement that sweeps snow out of the stands and thereby reduces the annual soil moisture. Several shrub and many herb species grow in these stands, but they form only a very sparse ground cover. Large patches of bare gravel are common.

Limber pine stands have generally been labelled topoedaphic climaxes 
TABLE 20. C-8B Aspen Stand Vegetation Data

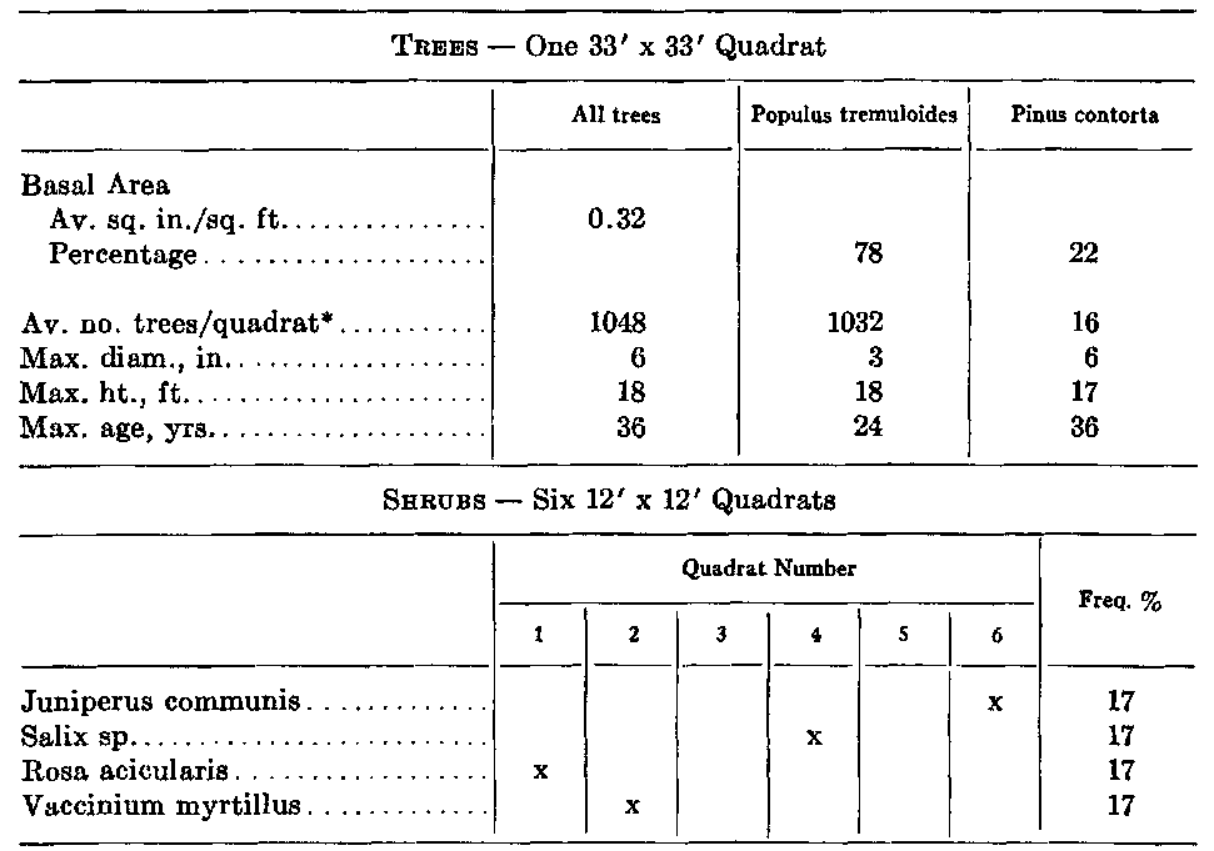

Herks - Twelve $3^{\prime} \times 3^{\prime}$ Quadrats

\begin{tabular}{l|c|c|c|c|c|c|c|c|c|c|c|c|c|c}
\hline & \\
\hline & & & \\
\hline
\end{tabular}

Note: Ten other species present in the quadrats with a frequency of less than 20 per cent are listed in the apecies list in Appendix I.

- Converted to $66^{\prime} \times 66^{\prime}$ quadrat equivalent. 
TABLE 21. C-RB Aspen Stand Vegetation Data

\begin{tabular}{|c|c|c|c|c|c|c|c|c|c|c|c|c|c|c|c|c|c|}
\hline \multicolumn{18}{|c|}{ Trees - Two $66^{\prime}$ x $66^{\prime}$ Quadrats } \\
\hline & \multicolumn{5}{|c|}{ All Trees } & \multicolumn{6}{|c|}{ Populus tremuloides } & \multicolumn{6}{|c|}{ Pinus contorta } \\
\hline $\begin{array}{l}\text { Basal Area } \\
\text { Av. sq. in./sq. ft..... } \\
\text { Percentage......... }\end{array}$ & \multicolumn{5}{|c|}{0.04} & \multicolumn{6}{|c|}{84} & \multicolumn{6}{|c|}{16} \\
\hline $\begin{array}{l}\text { Av. no, trees/quadrat. } \\
\text { Max. diam., in...... } \\
\text { Max. ht., ft. . . . } \\
\text { Max. age, yrg. . } \ldots \ldots\end{array}$ & \multicolumn{5}{|c|}{$\begin{array}{r}82 \\
7 \\
22 \\
46\end{array}$} & \multicolumn{6}{|c|}{$\begin{array}{r}78 \\
4\end{array}$} & \multicolumn{6}{|c|}{$\begin{array}{r}4 \\
7 \\
22 \\
36\end{array}$} \\
\hline $\begin{array}{l}\text { Stumps } \\
\text { Av. no./quadrat..... } \\
\text { Diam. range, in..... }\end{array}$ & \multicolumn{5}{|c|}{$\begin{array}{c}19 \\
3-12\end{array}$} & & & & & & & & & & & & \\
\hline \multicolumn{18}{|c|}{ ShrUBs - Eight $12^{\prime} \times 12^{\prime}$ Quadrats } \\
\hline & \multicolumn{15}{|c|}{ Quadrat Number } & \multirow{2}{*}{\multicolumn{2}{|c|}{ Freq. $\%$}} \\
\hline & \multicolumn{2}{|l|}{1} & \multicolumn{2}{|l|}{2} & 3 & & 4 & & 5 & & 6 & 7 & \multicolumn{3}{|c|}{8} & & \\
\hline $\begin{array}{l}\text { Vaccinium myrtillus.... } \\
\text { Juniperus communis.... } \\
\text { Arctostaphylos uva-ursi }\end{array}$ & \multicolumn{2}{|c|}{$\begin{array}{l}\mathbf{x} \\
\mathbf{x}\end{array}$} & \multicolumn{2}{|l|}{$\mathbf{x}$} & $\begin{array}{l}x \\
x\end{array}$ & \multicolumn{2}{|r|}{$\mathbf{x}$} & \multicolumn{2}{|r|}{$\mathbf{x}$} & & & & & & & \multicolumn{2}{|c|}{$\begin{array}{l}37 \\
37 \\
\mathbf{2 5}\end{array}$} \\
\hline \multicolumn{18}{|c|}{ Henss - Sixteen 3' x 3' Quadrats } \\
\hline & \multicolumn{16}{|c|}{ Quadrat Number } & 5 \\
\hline & 1 & 2 & 3 & 4 & 5 & 6 & 7 & 8 & 9 & 10 & 11 & 12 & 13 & 14 & 15 & 16 & 胥 \\
\hline 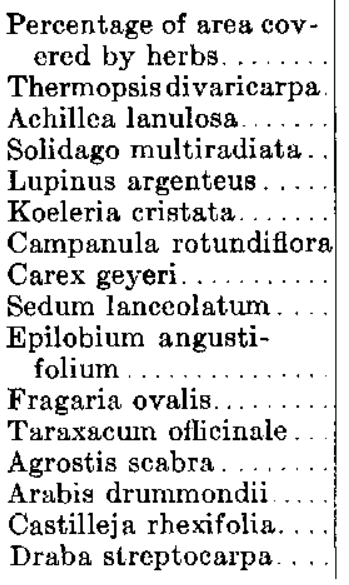 & $\begin{array}{c}20 \\
\mathrm{x} \\
\mathrm{x} \\
\mathrm{x} \\
\mathrm{x} \\
\mathrm{x}\end{array}$ & $\begin{array}{l}x \\
x \\
x \\
x \\
x \\
x\end{array}$ & $\begin{array}{l}20 \\
\mathrm{x} \\
\mathrm{x} \\
\mathrm{x} \\
\mathrm{x} \\
\mathrm{x} \\
\mathrm{x}\end{array}$ & $\begin{array}{l}28 \\
\mathrm{x} \\
\mathrm{x} \\
\mathrm{x} \\
\mathrm{x} \\
\mathrm{x} \\
\mathrm{x} \\
\mathrm{x} \\
\mathrm{x} \\
\mathrm{x} \\
\mathrm{x} \\
\mathrm{x} \\
\mathrm{x}\end{array}$ & $\begin{array}{l}35 \\
x \\
x \\
x \\
x \\
x \\
x \\
x \\
x \\
x \\
x \\
x \\
x\end{array}$ & $\begin{array}{l}33 \\
\mathbf{x} \\
\mathbf{x} \\
\mathbf{x} \\
\mathbf{x} \\
\mathbf{x} \\
\mathbf{x} \\
\mathbf{x}\end{array}$ & $\begin{array}{l}15 \\
x \\
x \\
x \\
x \\
x \\
x \\
x\end{array}$ & $\begin{array}{l}25 \\
\mathrm{x} \\
\mathrm{x} \\
\mathrm{x} \\
\mathrm{x} \\
\\
\mathrm{x} \\
\mathrm{x} \\
\mathrm{x} \\
\mathrm{x} \\
\mathrm{x} \\
\mathrm{x}\end{array}$ & $\begin{array}{l}35 \\
\mathrm{x} \\
\mathrm{x} \\
\mathrm{x} \\
\mathrm{x} \\
\mathrm{x} \\
\mathrm{x} \\
\mathrm{x} \\
\mathrm{x} \\
\mathrm{x} \\
\mathrm{x}\end{array}$ & $\begin{array}{l}27 \\
\mathrm{x} \\
\mathrm{x} \\
\mathrm{x} \\
\mathrm{x} \\
\mathrm{x} \\
\mathrm{x} \\
\\
\mathrm{x} \\
\mathrm{x}\end{array}$ & $\begin{array}{c}25 \\
\mathrm{x} \\
\mathrm{x} \\
\mathrm{x} \\
\mathrm{x} \\
\mathrm{x} \\
\mathrm{x}\end{array}$ & $\begin{array}{l}20 \\
x \\
x \\
x \\
x \\
x \\
x \\
x \\
x \\
x \\
x\end{array}$ & $\begin{array}{l}15 \\
x \\
x \\
x \\
x \\
x \\
x \\
x\end{array}$ & $\begin{array}{l}15 \\
x \\
x \\
x \\
x \\
x \\
x\end{array}$ & $\begin{array}{l}30 \\
x \\
x \\
x \\
x\end{array}$ & $\begin{array}{l}25 \\
\mathrm{x} \\
\mathrm{x} \\
\mathrm{x} \\
\mathrm{x} \\
\mathrm{x} \\
\mathrm{x} \\
\\
\mathrm{x} \\
\mathrm{x} \\
\mathrm{x} \\
\mathrm{x} \\
\mathrm{x}\end{array}$ & $\begin{array}{r}100 \\
88 \\
81 \\
75 \\
75 \\
69 \\
69 \\
69 \\
\\
65 \\
44 \\
44 \\
44 \\
37 \\
37\end{array}$ \\
\hline
\end{tabular}

Note: Eight other species present in the quadrats with a frequency of less than 20 per cent are listed in the apecies list in Appendix I. 
because of the belief that the site is too dry and windy for other species. This is probably correct for many limber pine stands. Douglas (1954), however, has demonstrated that some limber pine stands, perhaps far more than we realize, are actually successional to spruce-fir.

Two limber pine stands on Hill's Mill Ridge were studied in detail. Tables

Table 22, C-1A Limber Pine Stand Vegetation Data

\begin{tabular}{|c|c|c|c|c|c|}
\hline \multicolumn{6}{|c|}{ Trees - One $66^{\prime} \times 66^{\prime}$ Quadrat } \\
\hline & \multicolumn{2}{|c|}{ All Trees } & \multicolumn{2}{|c|}{ Pinus flexilis } & Pinus contorta \\
\hline 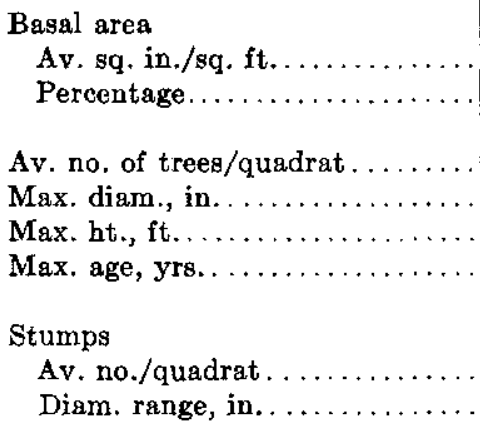 & & & & & $\begin{array}{c}1 \\
1 \\
- \\
-\end{array}$ \\
\hline \multicolumn{6}{|c|}{ Herbs - Four $3^{\prime}$ x $3^{\prime}$ Quadrats } \\
\hline & \multicolumn{2}{|c|}{ Qusdrat Number } & umber & 4 & Freq. \% \\
\hline 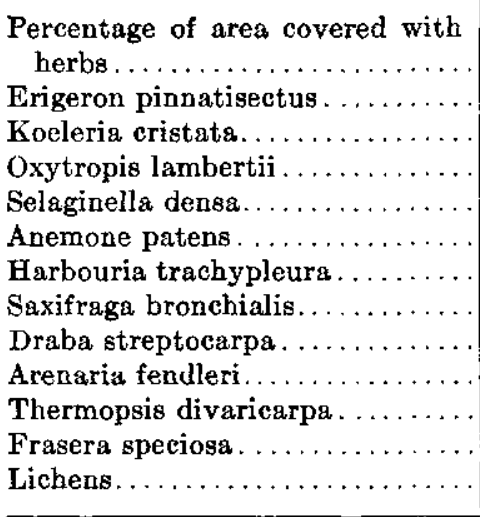 & $\begin{array}{l}3 \\
\mathrm{x} \\
\mathrm{x} \\
\mathrm{x}\end{array}$ & $\begin{array}{l}x \\
x\end{array}$ & $\begin{array}{c}25 \\
\mathrm{x} \\
\mathrm{x} \\
\mathrm{x} \\
\mathrm{x} \\
\mathrm{x}\end{array}$ & $\begin{array}{l}6 \\
x \\
x \\
x \\
x \\
x \\
x \\
x\end{array}$ & $\begin{array}{r}100 \\
75 \\
75 \\
75 \\
50 \\
50 \\
50 \\
25 \\
25 \\
25 \\
25 \\
75\end{array}$ \\
\hline
\end{tabular}


TABLE 23. C-1B Limber Pine Stand Vegetation Data

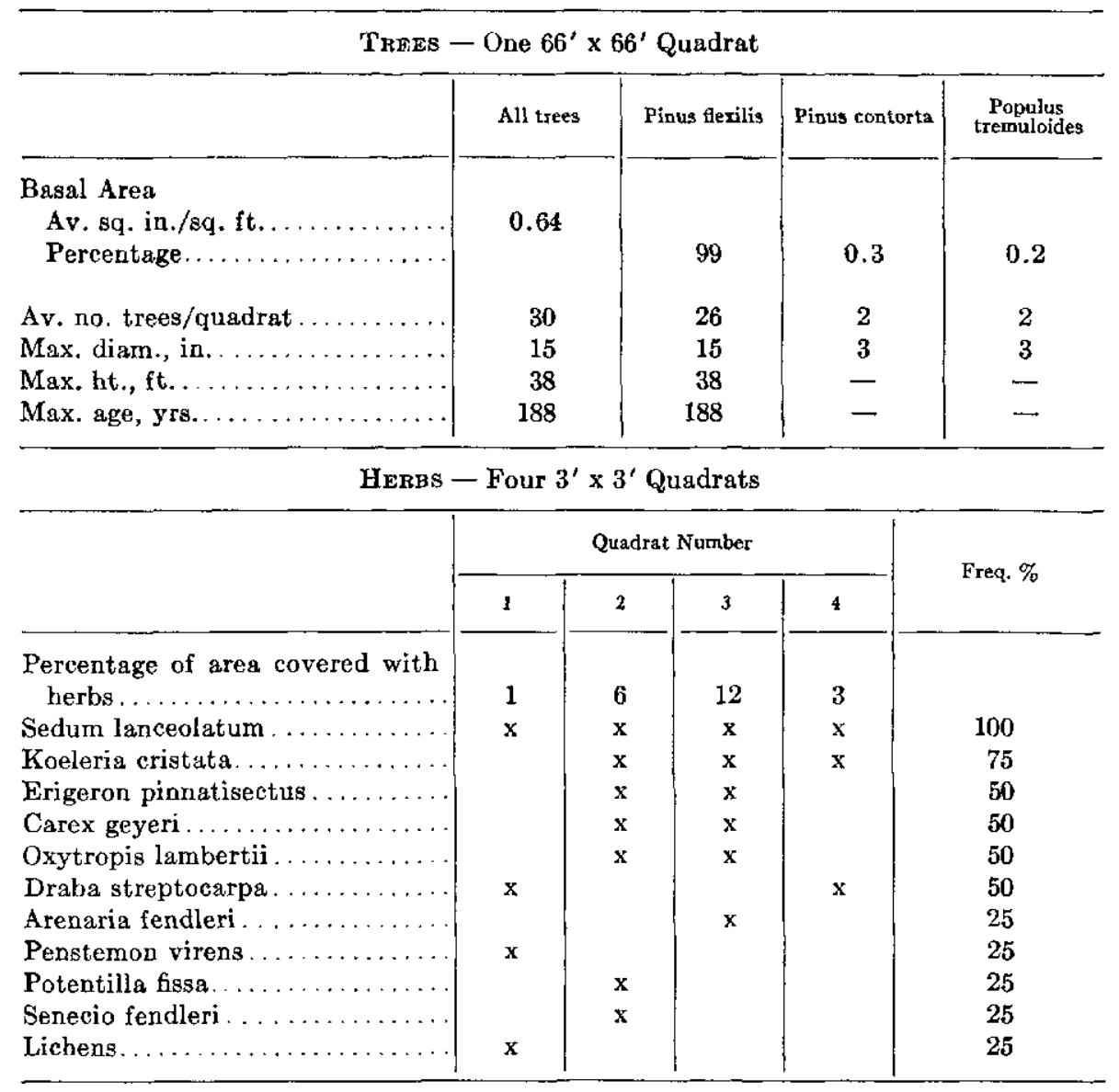

22 and 23 give quadrat data, and their external stand environment, as measured at Station C-1, located in a clearing just west of the two stands, is given in Appendix II. Some 60 years ago Stand C-1A was disturbed by lumbering, which reduced the density of trees significantly. It is likely that this is a spruce-fir site but that some earlier disturbance had destroyed or opened up the surrounding vegetation and exposed the site to strong winds. This environment gave limber pine an initial advantage in the revegetation process. The current stand is obviously successional, not yet having recovered from the lumbering. It is also likely that it will develop into a spruce-fir stand as sur- 
rounding forest develops and reduces wind velocity. Stand C-1B was not lumbered, and it is more exposed to wind because of its topographic setting. It appears to be a topographic climax.

\section{e. Willow-Birch Stand-Type}

Wet, marshy soils surrounding the glacial lakes that are abundant in this climax region provide an environment suitable for one of the most extensive shrub communities that we have in these mountains. Several species of willow (Salix spp.) and the dwarf birch (Betula glandulosa Michx.) (especially interesting because of its arctic alpine distribution) produce a community that may be very dense and reach a height of 3 to 4 feet. These shrubs are excellent windbreaks and cause an accumulation of snow up to near the level of their uppermost branches during the winter. These are successional stands in most sites; in sites where the water table is kept high by topographic relations they are probably topoedaphic-climax stands.

\section{f. Wet Sedge-Grass Meadow Complex}

Associated with the shrub stand above in the vicinity of lakes, there are wet, sedge-grass stand-types in which the plants grow very vigorously with their roots in a substratum usually saturated throughout the year. In some instances these communities are growing out over the water and are actually invading ponds in this way. These are successional stands that will be invaded by shrubs eventually in the processes of ecosystem change. Ramaley (1919 and 1920) recognized 15 types in this complex.

Both the shrub and sedge-grass stands are most common in valleys. The general atmospheric features of their external stand environment are illustrated by data collected at our C-4 station. Their soil features would differ from C-4 because their soil is largely organic and is saturated most of the year. Since there is no evidence in our area that atmospheric factors are directly controlling in the concentration of these stand-types in valleys, it appears that topoedaphic features are controlling. Therefore, the following comparison of the valley to the ridgetop station is presented to illustrate the localizing effects of topography on the atmospheric factors, not to suggest a control over vegetation.

Minimum temperature is the feature that differs most between $\mathrm{C}-1$ and $\mathrm{C}-4$, (Table 17), as is usual in valley-ridge comparisons. The seven degrees difference is somewhat less than usual, probably because the cold nocturnal air sometimes spills over the ridge and gives $\mathrm{C}-1$ a burst of the cold-air drainage. Thermograph charts of C-1 station often show the abrupt U-shaped trace that is characteristic for intervals of cold-air drainage. Other temperature 
features differed by only $2^{\circ}$ or $3^{\circ}$ between the two stations. There was over $25 \%$ more wind at C-4 than at C-1. Precipitation, soil moisture, and relative humidity were the same at the two stations. Snow cover cannot be compared, because observations at C-4 were made in the open beside a mile-long lake, while those at C-1 were made in a small opening in the forest.

In comparing these two stations, it is necessary to keep in mind that they differ in relation to the Divide as well as in topography, C-1 being farther from the Divide.

\section{g. Dry Subalpine Meadow Stand-Type}

Dry subalpine meadows are common as successional stands following lumbering and/or fire. A dry meadow was studied, just south and west of Station C-1; Antennaria parvifolia Nutt., Oxytropis lambertiana Pursh, Carex spp., Erigeron pinnatisectus (Gray) Nels., Sedum lanceolatum Torr., Thermopsis divaricarpa Nels., and Taraxacum officinale Web. were the most common herbs. Additional species are listed in the species list in Appendix I. The meadow's external stand environment is given in the summary for Station C-1.

There are many stumps in the meadow, and both lodgepole pine and aspen are invading it and could change it to a forest stand in a few decades. Other dry meadows in the subalpine may be edaphic elimaxes (Robbins 1918).

\section{The Alpine Tundra Climax Region}

\section{REgIONAL CHARACTERISTICS}

Geography and Geology: The alpine tundra lies above the subalpine forest on all ridges and peaks that rise above the general level of tree-limit at an elevation of about 11,400 feet. It is often called the "alpine zone".

The alpine tundra is a land of striking contrasts in space and time. Gently rolling surfaces end abruptly at the foot of stecp, jagged ridges, or at the lip of cliffs hundreds of feet high. Fine-textured soil particles form "centers" scattered through a matrix of large rocks often several feet in diameter (Plate 4); in one place the rocks rise several feet above the fines, in another place the fines form flat-topped mounds or stripes whose tops are, incongruously, several feet above the bouldery matrix. One square meter of soil has been stable for hundreds of years, while in an adjacent square meter plants were uprooted last night by "frost heave". Some areas are snow-free $95 \%$ of the year, while a fow meters away snow covers the ground 11 months of the year; the "growing season" of any one plot may be from zero to 70 days. Moss campion (Silene acaulis L.), the pinkish-flowered cushion plant, 
flowers in June in one area and in September in another area less than 100 feet away. Lush sedge-grass meadow covers areas where ground water comes close to the surface all summer; an adjacent area that receives little moisture has a sparse plant cover. Calm, warm, clear weather may change in a few minutes to the dark, frightening cold of an electrical storm and then, just as abruptly, change back to the lazy warmth that preceded the passing thunder storm. The perennial Geum rossii grows 8 inches tall with many flowers during a favorable summer, while the following year may be so unfavorable that the same plant in the same habitat is only a few inches tall and has few if any flowers.

The alpine tundra of America has not been studied as thoroughly as has its counterpart on other continents. Papers by Braun-Blanquet (1948 and 1949), Ludi (1921), and Schroeter (1926) in the Alps, Dahl (1956) in Scandinavia, and Costin (1954) in Australia are examples of outstanding ecological studies of alpine tundra regions. Many early American ecologists visited the Front Range tundra and some published brief accounts (Cooper, 1908), but Cox published the first intensive ecological study in this climax region in 1933. Kiener's unpublished thesis (1939) on Long's Peak, and the United States Forest Service pamphlet by Schwann and Costello (1951), covering the entire Rocky Mountains, are valuable studies of tundra. The latter authors emphasize the economic importance of the alpine, in which they include the foresttundra transition region, with the statement that it contributes over $20 \%$ of all stream flow from the mountains although it covers only $3 \frac{1}{2} \%$ of Colorado's surface area. It is not surprising that interest in basic alpine research, such as the studies of Martinelli (1959) on the hydrology of late-lying snowfields, has been inereasing in recent years.

Geology: The spectacular cliffs and sharp peaks that one usually thinks about in recalling views of "the mountains" are only one type of high mountain landscape; many square miles of alpine tundra resemble gently rolling grasslands of the Great Plains. The character of any one arca depends on whether its topography was produced largely by valley glaciers or by forces of cryoplanation (leveling by ground-ice action). Along the Continental Divide, the backbone of the Front Range, rugged topography is the rule although even here there are many gentle slopes and almost flat ridge tops. Eastward from the Divide, the topography becomes progressively less spectacular because effects of valley glaciers diminish. Many round-topped ridges that have escaped glaciation since before the Wisconsin epoch extend eastward from a fraction of a mile to several miles. Niwot Ridge, the center of our alpine research area, is over four miles long, and its area of gentle topography averages a mile in width. Cliffs do occur at its western end, but along the remainder of its borders slopes are gentle. 
The major valleys have the broad U-shaped cross-section profile and a giant-step longitudinal profile characteristic of glacial valleys, and they terminate in glacial cirques whose cliffs may be over 1,000 feet high. Some of these cirques are over a mile wide. Gentle valley slopes and broad ridge tops are always terraced into broad steps by solifluction. There are many hanging valleys, nivation hollows, talus slopes, and some rock glaciers.

Small moraines occur near the front of current glaciers in the heads of some valleys, and they usually form the dam for a small lake. Most valleys have a long series of lakes, at least one on each of the glacier-produced steps. Ponds are common both in valleys and on slopes and ridges.

Congeliturbation, solifluction, frost heaving and boiling, and other forces related to gravity, saturated soil, and frequent freeze-thaw cycles of soil water have been very active in past times and are currently active wherever there is an abundance of soil water during part of the spring and fall. These forces have produced a variety of terraces, stone garlands, polygons, stripes, sortednets, frost boils, and other types of "patterned ground" (Washburn, 1956). Billings and Mooney have suggested the presence of cyclical phenomena in one type of pattern (1959). Landslides are rare in the tundra. Permanent and semi-permanent snowbanks are common; these banks are probably more extensive on south- than on north-facing slopes because the prevailing wind blows from slightly north of west and therefore deposits more snow on south exposures. Snow avalanches are fairly common in the spring, especially after intervals of unusually heavy snowfall.

Sonils: Like other tundra features, soils (used here in the broad sense) vary greatly, from fields of six-foot boulders to fine silt-clay in the centers of polygonal soil patterns. Soils analyzed from a kobresia meadow were silty-loams (Table 24). All soils have been subject to one or more of the geomorphic processes mentioned above of heaving, thrusting, sorting, and movement down-slope, even on gentle gradients, due to freeze-thaw cycles of soil water. Some flat, well-drained upland areas have been stable for a long time, but areas where there is an abundance of water during intervals of freeze-thaw are currently active.

The soil is very rocky, except on some slopes that escaped more recent glaciations and, therefore, have deep, residual or colluvial, relatively finegrained parent material. Silt and clay have probably been blown into the tundra from glacial outwash or lake deposits. Even today, wind-blown soil particles collect in pockets of eroded snow during the winter, and dust sometimes covers snowdrifts in the spring.

Soil profiles are well developed where the soil has been stable for a considerable time. The upper horizon is very rich in humus in some stand-types and 
TABLE 24. Alpine Soils Data

\begin{tabular}{|c|c|c|c|c|c|c|}
\hline \multirow{3}{*}{ Stand } & \multirow{3}{*}{ Depth, inches } & \multirow{3}{*}{ Soil Type } & \multicolumn{4}{|c|}{ Mechanical Analysis: Particle Size in mm. } \\
\hline & & & \multirow{2}{*}{$\%$ over 2} & \multicolumn{3}{|c|}{ Percentages of Fraction under 2} \\
\hline & & & & $2-0.05$ & $0.05-0.002$ & below 0.002 \\
\hline D-1 & $\begin{array}{l}0-6 \\
6-12\end{array}$ & $\begin{array}{l}\text { Silt loam } \\
\text { Silt loam }\end{array}$ & $\begin{array}{l}18 \\
22\end{array}$ & $\begin{array}{l}41 \\
38\end{array}$ & $\begin{array}{l}51 \\
55\end{array}$ & $\begin{array}{l}7 \\
8\end{array}$ \\
\hline $\mathrm{D}-2$ & $\begin{array}{l}0-6 \\
6-12\end{array}$ & $\begin{array}{l}\text { Sandy loam } \\
\text { Silt loam }\end{array}$ & $\begin{array}{r}6 \\
29\end{array}$ & $\begin{array}{l}53 \\
39\end{array}$ & $\begin{array}{l}41 \\
54\end{array}$ & $\begin{array}{l}6 \\
8\end{array}$ \\
\hline D-3 & $\begin{array}{l}0-6 \\
6-12\end{array}$ & $\begin{array}{l}\text { Sandy loam } \\
\text { Silt loam }\end{array}$ & $\begin{array}{l}0.4 \\
22\end{array}$ & $\begin{array}{l}59 \\
35\end{array}$ & $\begin{array}{l}34 \\
57\end{array}$ & $\begin{array}{l}7 \\
8\end{array}$ \\
\hline $\mathrm{D}-4$ & $\begin{array}{l}0-6 \\
6-12\end{array}$ & $\begin{array}{l}\text { Silt loam } \\
\text { Silt loam }\end{array}$ & $\begin{array}{l}24 \\
24\end{array}$ & $\begin{array}{l}42 \\
40\end{array}$ & $\begin{array}{l}50 \\
51\end{array}$ & $\begin{array}{l}9 \\
9\end{array}$ \\
\hline
\end{tabular}

may be up to 12 inches thick. Below the humus layer, there may be a slight, inconspicuous concentration of clay and silt.

Soil ice occurs in all sites during the winter and persists throughout the year in some sites. The depth and extent of permanently frozen ground ("permafrost") is not yet known. Retzer (1956) describes 3 major soil groups and several sources of information on permafrost.

Climate: The regional atmospheric environment of the tundra is less well known than that of other climax regions because it has not supported the settlements at which such data have traditionally been collected. The Pike's Peak records (Greely, 1891), 9 years of data on Corona Pass (U. S. Weather Bureau 1933), and several brief summer observations, such as Kiener's (1939) on Long's Peak and Bliss's (1956) in the Medicine Bow Mountains, are of interest. Our D-1 station data provide the first information for an entire year that has been collected in the Front Range since 1912.

The alpine-tundra summer is very short, and cool to cold; thunderstorms are frequent, and they sometimes yield sleet and hail. Autumn is short, clear, dry, and mostly cold, but with a few warm days between the passage of coldfront storms. The winter is long, very cold, very windy, and more cloudy than other seasons; blizzards are frequent and severe, but their contribution of moisture to large areas of the tundra is limited, because much of the snow blows into drifts or down into the forest. 'The spring is short, cool, and wet at the beginning; there is usually a drought interval in late spring or early summer. Strong winds are always from the west, the prevailing wind direction. Significant amounts of precipitation come with both east and west winds. 
It is interesting to compare the tundra-region environment (D-1 station) with that of the subalpine (C-1 station) because of the difference in the growth form of the dominant plants in the two regions (Table 9).

Tundra air temperatures were 4 to 13 degrees lower, varying with the feature under comparison. The least difference is between minimum temperatures, a situation found in other comparisons above and accounted for partly by the fact that the cold-air masses that bring the lowest temperatures to the east slope are so well mixed that altitudinal temperature differences are reduced; in addition, C-1 sometimes receives cold-air drainage from the Green Lakes Valley, while D-1 is never affected by this phenomenon. Temperature differences were greater in soil than in the air, ranging from $9^{\circ}$ to $19^{\circ}$ colder in the tundra. There were almost twice as many frost-free days in the summer period in the subalpine as in the alpine, 87 as compared with 45 days. There is a spectacular increase in wind in the 2,200-foot increase in altitude between C-1 and D-1. The tundra, with about 160,000 miles in the year, had almost twice as much wind as the subalpine. The precipitation gauges received the same amount of water at the two stations, but this does not mean that the "precipitation" in the strict sense was the same. There is an inverse relationship between the amount of wind at a site and the amount of snow a gauge will collect at that site. Consequently, although data free from wind effects indicate that the tundra does receive more precipitation than the subalpine, we do not know the precise amount involved. These data from a single year have only limited significance, but it is interesting to note that during June, July, and August, the months with the least wind and with precipitation in the form of rain or wet snow and therefore less susceptible to drift by wind, there was significantly more precipitation at $D-1$. It will be interesting to see if the data of subsequent years show a similar relationship.

Soil-moisture comparisons between C-1 and D-1 are complicated by the fact that the D-1 soil has a much higher humus content and therefore higher water-holding capacity. The soil moisture was much higher at D-1 throughout the year. Relative humidity was also higher in the tundra by about $18 \%$.

It is interesting to note that these differences between the environment of the tundra region and that of the adjacent forest region are much greater than between any two adjacent forest regions described in earlier sections.

Vegetation: Alpine-tundra vegetation is dominated by low, perennial sedges, grasses, herbs, and minute shrubs; it is highly variable in character but is distinguished from other climax regions by the complete absence of upright trees and tall shrubs. From a distance, the tundra appears to be a barren topping to peaks and ridges; viewed close at hand, however, it is found to have many areas of lush plant cover although some habitats are truly barren. Areas of homogeneous vegetation may cover several acres, but often cover 
only a few square feet because the environment changes abruptly and frequently.

Where the soil is stable, fine, and moist, and snow does not lie too late, grasses and grass-like sedges form a continuous plant cover six to ten inches deep. Many colorful flowers mingle with the dominants. On coarse or relatively dry soil and late-lying snow sites, the plant cover is incomplete; bare ground intervenes between rosettes, tufts, and "cushions". These cushionplants have "woody" stems with intricate branching systems, but they never rise over a few inches above the ground. Willow shrubs with catkins 2 inches tall never raise a branch off the ground. Their larger relatives, the shrubs with genetic capacity to grow upright, are found only in depressions where rocks and snow protect them from the winter wind. Boulder fields may have a few vascular plants growing in the coarse soil that collects between the boulders, but many acres of this rocky land are entirely devoid of plants except for lichens encrusted on the rock surfaces.

There are only a few annual species in this vegetation, and Holch, et al. (1941) concluded that reproduction of the perennials was largely vegetative because they did not have time to set seed. Osburn (1958), however, has demonstrated that many species do set seed and that they germinate profusely under natural conditions. 'lerrestrial fruticose lichens, that are so conspicuous in some aretic tundra, are rare in the alpine tundra, but foliose ground lichens are common in many stands.

The vegetation is influenced profoundly by snow fields and their influence on other environment factors, such as the length of the growing season. The most hardy climatic-climax species in the tundra tolerate the absence of continuous snow cover throughout the winter and, in fact, are intolerant of continuous, even though shallow, winter cover. Where snow lics all winter, but melts early in spring, there is a good plant cover; but where snow lies later and later, the plant eover becomes less and less complete. Some sites of very late-lying snow are devoid of vascular plants but may support a thin cover of mosses and lichens. Many snowbank sites are surrounded by irregular-shaped zones of plants that often get smaller, and cover the ground less completely, from the outside toward the last snow to melt. In many other snow-accumulation sites, factors other than the length of the snow-free period predominate in determining the character of the vegetation, and the classical centrifugal vegetation zonation is lacking. Gjaerevoll (1956) and Dahl (1956) have studied the interactions of snow and vegetation in Scandinavia, and Billings and Bliss (1959) describe one snowbank area in the Medicine Bow Mountains north of the Front Range. Martinelli (1959) has studied hydrological features of snowfields in the Front Range. 
Congeliturbation, solifluction, depth and duration of snow cover, and activities of the pocket gopher (Osburn, 1958) are among the most powerful controls of the characteristics of the vegetation in the alpine tundra. Plants are excluded from arcas when these forces are most activc, and they lead a precarious existence in any site potentially subject to the activities of these soil movers. Once a bare area has becn produced, needle-ice becomes a powerful force that inhibits revegetation by uprooting seedlings (Schramm, 1958) and probably also enlarges the bare area by tearing up the marginal vegetation. There is a delicate balance between the forces of frost action and those of revegetation. Even after the plant cover is broken, frost action may be dominant for only a few years before revegetation stabilizes the substratum. Small areas averaging 12 inches in diameter, in many stages of vegetation destruction and revegetation, are abundant on Niwot Ridge. These small "active" areas often occur singly or in groups in the relatively fine center of a much larger and currently stable sorted-net pattern (Plate 4).

All of the above-described environment-factor complexes, working alone or in combinations, break up the tundra landscape into a mosaic of standtype ecosystems in which the individual units may be only a few inches in diameter and are rarely over a few acres in cxtent. This heterogeneity in plant cover has frustrated many efforts at classification and caused many botanists to conclude that there is no "sense" at all to tundra vegetation. This is natural since most of us are accustomed to the larger units visible in forest and grasslands; it is difficult to change one's perspective and become sensitive to these minute stands in the tundra, where one's foot may rest at one instant on two dissimilar stands. But there are recognizable stands in the alpine tundra, and their characteristics and arrangement can be recognized and described.

\section{THE MAJOR STAND-TYPES}

Selection of stands for intensive study in the tundra was influenced in part by accessibility. Since it had been decided at the outset that field studies would be continued throughout the year, it was essential to select stands that could be reached from Science Lodge without unreasonable handicaps. Several winters of research in the Lodge area had given a few students and me an orientation in the kinds of problems that would be encountered in the higher country, but we were to learn much in the new program about the magnitude of some of the problems. The success of the project hung by a thread on numerous occasions while some new difficulty was studied and overcome.

Variety and regional significance were additional features considered in 
selecting study stands. I soon found that, in common with most American alpine botanists, I could not distinguish stands in tundra that were equal in basic character to forest stands. It was simple to distinguish between "fellfields" (stands in which rocks and cushion-plants are conspicuous) and "wet meadows", but these did not appear to be comparable to an aspen grove or a ponderosa pine stand in the sense of being relatively homogeneous ecological entities. Furthermore, it was puzzling to find that the exposure differences in the landscape that are so conspicuous in the lower mountains were not evident in the tundra. A similar situation had been detected in the subalpine, but somehow it seemed that in the "rugged" tundra environment, topographic contrasts should be conspicuous.

As we became more familiar with the tundra, through detailed study and repeated visits every week of the year and in every type of weather, solutions to these two puzzles gradually unfolded. It became evident that degree of soil movement, exposure to wind, and accumulation of snow all worked to overcome the effects of exposure to solar radiation. And then one spring day, when the bright pink alpine primula (Primula angustifolia Torr.) and the pale blue phlox (Phlox pulvinata (Wherry) Cronquist) were at the height of their flowering, true tundra stands suddenly became visible to me. The two species were mutually exclusive. One area of several square meters had only phlox while next to it another area had only primula. Immediately after I became conscious of this segregation of species, I remembered that the tundra I was traversing had been a mosaic of snow-covered and snow-free areas most of the winter. It then became obvious that these areas differed in both environment and species composition, phlox being conspicuous in the more exposed and less snow-covered areas. These areas, therefore, might be true stands in the sense that I was using the term in the other regions. Subsequent observations revealed that they were true stands comparable in basic character to a forest stand, and in time I learned to recognize many more such tundra stands, one by one. The following autumn, acres of kobresia (Kobresia myosuroides (Vill.) Fiori \& Paol) around our stations took on a beautiful golden hue that contrasted sharply with the colors of adjacent areas and revealed the important type that we now believe is a true climatic-climax stand-type. It was interesting to discover still later that three different types of stands could be separated on the basis of which of the three local species of clover (Trifolium nanum Torr., T. dasyphyllum T. \& G., and T. parryi Gray) occurred in a given stand.

The beginning of an understanding of certain aspects of tundra ecology actually came months and years after the time when it was imperative that study sites be selected. Selection was based, therefore, on several considerations other than the identity of local stands. An attempt was made to get 
to as high an altitude as possible and to locate in areas that had regional significance. Niwot Ridge, west and north of Science Lodge, proved to be reasonably satisfactory. It had large areas of the rolling landscape that is common in the Front Range tundra, and it was not far from our field headquarters, in miles at least. In order to conform with the total project design, areas for study were selected on the broad ridgetop, north and south slopes, and valley floor. The elevation of the first three stations, 12,300 feet, was reasonably satisfactory, for that was well above the lower limits of the tundra region. It would have been impractical, however, to go far enough up a valley to get to the same elevation; consequently, a valley site directly below the ridge stations and on one of our two travel routes was selected. It was only 11,700 feet in elevation and, therefore, not much above the regional treelimit, but its stands were distinctly tundra in character.

Our years of research on Niwot Ridge have revealed that it is an excellent area for tundra research, but we have not had enough time yet to work out a complete classification of stands. The mosaic of stands is complex, and there is little background in the literature to help us out. William Osburn has now been working on these areas for several years and will soon publish the results of his work. In this paper, I will present data on only a few of the more conspicuous stand-types.

All the evidence now available indicates that each of the stands I will describe is a climax entity. Osburn (1958) has identified and worked out the fascinating ecological study of a series of unstable "successional" stands produced by activities of pocket gophers (Thomomys talpoides fossor Allen). The type of stand in any one site in his series depends upon whether or not gophers are currently active or, if they are absent, the length of time since their departure. This is an interesting example of ecosystems "controlled" by animals, a somewhat unusual situation in a completely natural landscape.

\section{a. Kobresia Meadow Stand-Type}

A kobresia meadow stand is an incongruous combination of environment and vegetation; this stand is snow-free most of the winter, and it would be logical to expect such a severe site to have a sparse plant cover, but instead the plants form a sward that compares favorably with many types of meadow in more moderate environments (Plate 5). Kobresia plants are tufts of stiff needle-like leaves rising above a flat-topped mass of leaf bases and stems attached to a mass of fibrous roots. The leaves die back to this basal mat each fall. The tufts may grow so close together that all other species are excluded, but in most square feet of this stand there are openings between tufts that give space for a variety of other species.

Kobresia meadow stands occur on level to gently rolling surfaces (occasion- 
ally on steep slopes) with fine soil that is normally moist during the growing season and has been stable for a very long time, at least several hundred years. They are always exposed to strong winds that sweep them clean of snow soon after each winter snow storm, leaving the plants exposed to the cold, dry atmosphere most of the winter. In the spring, snow does blanket the kobresia stands completely, but it rarely gets over a foot deep and it always melts at the very beginning of the growing season.

We studied two kobresia stands intensively. Stand D-1A surrounds the D-1 tundra environment-measurement station and the Institute's Tundra Laboratory. It covers several acres of the moderately level 215-yard-wide crest of Niwot Ridge near its west end. Giant polygons or sorted-nets, with units 10 to 15 feet across, developed in some past age under a climatic regime different from today on the ancient glacial till that caps this part of the ridge. The centers of this pattern are of fine soil particles some of which may be of eolian origin. These centers of fines support a vigorous growth of kobresia and have an interesting soil profile. The upper 6 to 12 inches is a very black, humus-enriched horizon similar to that of temperate zone grassland. The lower boundary of this black horizon is rather sharp; below it there is a thin layer high in clay resting on a much thicker horizon of sand. This sandy horizon grades into coarse fractured blocks of parent material within three feet of the ground surface.

The structure of the soil profile suggests the nature of the soil-water dynamics, a feature that may be paramount in controlling the nature of this stand-type. The humus-rich horizon holds great volumes of water against pull by both gravity and plants, fortunately more from the former. Whatever water gets through that horizon sinks rapidly to lower levels out of reach of plants. Studies of soil-moisture variations indicate that very little water leaves this ecosystem by that pathway. It is possible that the well-drained feature explains the stability of the soil in this stand. The patches of fine soil that hold water are suspended in a matrix of coarse, well-drained rock debris; the patches frecze and thaw as units in a way that precludes turbulence and sorting commonly associated with frecze-thaw in tundra.

The rockiness of the ground in this stand is illustrated by the fact that $38 \%$ of the surface, as measured along 766 -foot transects, was rock.

The fine soil in the center of each polygon grades outward into progressively coarser material and is finally replaced by the rocks and boulders that fill the depressions around each polygon. Kobresia dominates the fine soil, but where soil gets too thin for it, Geum rossii (R. Br.) Ser., Trifolium dasyphyllum, and Selaginella densa Rydb. become abundant. These latter species are actually pioneering on the coarser substratum. As the soil gets decper as a result of the activities of the pioneers, kobresia becomes abundant. Thus each patch 
of kobresia has a peripheral zone of pioncers. Flowering plants are rare among the rocks in the borders of polygons, but lichens and mosses are abundant on the rock surfaces.

When kobresia takes on its beautiful golden autumn hue and other plants have wilted, the D-1 kobresia stand appears to be homogeneous and completely lacking in other species except for the pioneers mentioned above. Careful observation, however, reveals the heterogeneity common to most stands. Patches of cushion plants grow in micro-sites of unusually strong wind, and patches and small stands of Parry's clover meadow break the kobresia carpet where snow accumulates most of the winter. In a similar way, individual herbs and cushion-shrubs grow on minute patches of soil that for one reason or another lack kobresia tuft. Table 25 on the vegetation shows that 12 species besides kobresia have high frequency in this stand.

TABLE 25. D-1A Kobresia Meadow Stand Vegetation Data

\begin{tabular}{|c|c|c|c|c|c|c|c|c|c|c|c|c|c|}
\hline & \multicolumn{12}{|c|}{ Quadrat Number $(3 \times 3$ feet $)$} & \multirow{2}{*}{ Freq. \% } \\
\hline & 1 & 2 & 3 & 4 & 5 & 6 & 7 & 8 & 9 & 10 & 11 & 12 & \\
\hline $\begin{array}{r}\text { Percentage of area covered by } \\
\text { plants } \ldots \ldots \ldots \ldots \ldots \ldots \ldots \ldots \ldots\end{array}$ & 90 & 90 & 85 & 85 & 95 & 85 & 80 & 75 & 80 & 85 & 80 & 80 & \\
\hline Arenaria obtusiloba............ & $\mathrm{x}$ & $\mathrm{x}$ & $\mathrm{x}$ & $\mathrm{x}$ & $\mathrm{x}$ & $\mathrm{x}$ & $\mathrm{x}$ & $\mathrm{x}$ & $\mathrm{x}$ & $\mathrm{x}$ & $\mathrm{x}$ & $\mathrm{x}$ & 100 \\
\hline Campanula uniflora. & $\mathrm{x}$ & $\mathrm{x}$ & $\mathrm{x}$ & $\mathrm{x}$ & $\mathrm{x}$ & $\mathrm{x}$ & $\mathbf{x}$ & $x$ & $\mathrm{x}$ & $\mathrm{x}$ & $\mathbf{x}$ & $\mathrm{x}$ & 100 \\
\hline Eritrichium aretioides. & $\mathbf{x}$ & $\mathrm{x}$ & $\mathrm{x}$ & $\mathrm{x}$ & $\mathrm{x}$ & $\mathrm{x}$ & $\mathrm{x}$ & $x$ & $\mathrm{x}$ & $\mathrm{x}$ & $\mathrm{x}$ & $\mathrm{x}$ & 100 \\
\hline Geum rossii $\ldots \ldots \ldots \ldots \ldots$ & $\mathrm{x}$ & $\mathrm{x}$ & $\mathrm{x}$ & $\mathrm{x}$ & $\mathrm{x}$ & $\mathrm{x}$ & $\mathrm{x}$ & $x$ & $x$ & $\mathrm{x}$ & $\mathrm{x}$ & $\mathrm{x}$ & 100 \\
\hline Kobresia myosuroides....... & $\mathrm{x}$ & $\mathrm{x}$ & $\mathrm{x}$ & $\mathrm{x}$ & $\mathbf{x}$ & $\mathrm{x}$ & $\mathrm{x}$ & $\mathrm{x}$ & $\mathrm{x}$ & $\mathrm{x}$ & $x$ & $\mathrm{x}$ & 100 \\
\hline Lloydia serotina. ...... & $\mathrm{x}$ & $\mathrm{x}$ & $\mathrm{x}$ & $\mathrm{x}$ & $\mathrm{x}$ & $\mathrm{x}$ & $\mathrm{x}$ & $\mathrm{x}$ & $x$ & $\mathrm{x}$ & $\mathbf{x}$ & $\mathrm{x}$ & 100 \\
\hline is alpina. & $\mathrm{x}$ & $\mathrm{x}$ & $\mathrm{x}$ & $\mathrm{x}$ & $\mathbf{x}$ & $\mathrm{x}$ & $\mathbf{x}$ & $\mathbf{x}$ & $x$ & $\mathrm{x}$ & $\mathrm{x}$ & $\mathrm{x}$ & 100 \\
\hline lvinata... & $\mathbf{x}$ & $\mathrm{x}$ & $\mathrm{x}$ & $\mathrm{x}$ & $\mathrm{x}$ & $\mathrm{x}$ & $\mathbf{x}$ & $\mathrm{x}$ & $\mathrm{x}$ & $\mathbf{x}$ & $\mathrm{x}$ & $\mathrm{x}$ & 100 \\
\hline lla densa................ & $\mathbf{x}$ & $\mathrm{x}$ & $\mathrm{x}$ & $\mathbf{x}$ & $\mathbf{x}$ & $\mathrm{x}$ & $\mathbf{x}$ & $\mathrm{x}$ & $\mathrm{x}$ & $\mathrm{x}$ & $\mathrm{x}$ & $\mathrm{x}$ & 100 \\
\hline Trifolium dasyphyllum........ & $x$ & $\mathbf{x}$ & $\mathrm{x}$ & $\mathbf{x}$ & $\mathrm{x}$ & $\mathrm{x}$ & $\mathbf{x}$ & $\mathrm{x}$ & $x$ & $\mathrm{x}$ & $\mathrm{x}$ & $\mathrm{x}$ & 100 \\
\hline llorum. & $\mathrm{x}$ & $\mathrm{x}$ & $\mathrm{x}$ & $\mathbf{x}$ & & $\mathrm{x}$ & $\mathrm{x}$ & $\mathrm{x}$ & $x$ & $\mathrm{x}$ & $\mathrm{x}$ & $\mathrm{x}$ & 92 \\
\hline Polygonum bistortoides. .... & $\mathrm{x}$ & $\mathrm{x}$ & $\mathrm{x}$ & $\mathrm{x}$ & $\mathrm{x}$ & $\mathrm{x}$ & & & $x$ & $\mathbf{x}$ & $\mathrm{x}$ & $\mathrm{x}$ & 83 \\
\hline Polygonum viviparum....... & $\mathrm{x}$ & $\mathrm{x}$ & $\mathbf{x}$ & $\mathrm{x}$ & $\mathrm{x}$ & & $\mathrm{x}$ & $\mathbf{x}$ & $x$ & & $\mathrm{x}$ & $x$ & 83 \\
\hline Poa aretica. . & $\mathrm{x}$ & $\mathrm{x}$ & $\mathrm{x}$ & $\mathrm{x}$ & & $\mathrm{x}$ & & & $\mathrm{x}$ & $\mathbf{x}$ & & & 58 \\
\hline Draba erassifolia............ & $\mathbf{x}$ & & $\mathrm{x}$ & & & & & & $\mathrm{x}$ & $\mathrm{x}$ & & $\mathbf{x}$ & 42 \\
\hline Draba fladnizensis. . & & $x$ & $\mathbf{x}$ & & $x$ & & $\mathrm{x}$ & & $x$ & & & & 42 \\
\hline Gentiana tenella... & & $\mathrm{x}$ & $\mathrm{x}$ & & & $\mathrm{x}$ & & & & & & $\mathrm{x}$ & 33 \\
\hline Potentilla rubricaulis. . & $x$ & $\mathrm{x}$ & & & & & & & & & $\mathrm{x}$ & $\mathrm{x}$ & 33 \\
\hline Trifolium nanum...... & & & & & $\mathrm{x}$ & & $\mathrm{x}$ & & $x$ & $\mathrm{x}$ & & & 33 \\
\hline Arenaria fendleri............ & & $\mathrm{x}$ & & & & $\mathrm{x}$ & & & $x$ & & & & 25 \\
\hline Saxifraga rhomboidea........ & $\mathrm{x}$ & & $\mathrm{x}$ & & & & & & & & & $\mathrm{x}$ & 25 \\
\hline Silene acaulis.............. & & & $\mathrm{x}$ & & $x$ & & & & & & & $x$ & 25 \\
\hline Lichens. . ... & $x$ & $\mathrm{x}$ & $\mathrm{x}$ & $x$ & $\mathrm{x}$ & $\mathrm{x}$ & $\mathrm{x}$ & $\mathrm{x}$ & $\mathbf{x}$ & & $\mathbf{x}$ & $\mathrm{x}$ & 92 \\
\hline
\end{tabular}

Note: Eleven other species with a frequency of less than 20 per cent in the quadrats are listed in the species list in Appendix $\mathbf{I}$. 
External stand environment data for this stand are in Appendix II; soil data are in Table 24.

There has been considerable debate over whether or not a true climax can exist in tundra regions. Churchill and Hanson (1958) have reviewed the arguments on both sides of the question and concluded that the concept can be applied to tundra. My study of the kobresia meadow has led me to conclude that it is a true climax ecosystem. After reaching this conclusion from my own field research, I found that Cox (1933) had reached the same conclusion much earlier in his studies on James Peak only 20 miles south of Niwot Ridge. Since it is moderate in most environment factors, it is reasonable to consider kobresia meadow on relatively flat surfaces as the climatic climax of the Front Range alpine tundra region.

A second kobresia stand, Stand D-2A, occurs on the north-facing slope (17\%) near the Tundra Laboratory and is essentially continuous with Stand D-1A. The data in Tables 25 and 26 show that the two stands really are very similar. The presence of Primula and Oxyria in D-2A stand results from the presence of several small, shallow depressions which accumulate snow. It would be reasonable, in this general study, to lump these two stands into a single unit; they are kept separate, however, in order to illustrate the basic homogeneity of the type in spite of exposure differences.

The similarity in the vegetation of D-1 and D-2 stands suggests that they have similar environments, and comparisons of the data we collected (Table 27) agree with that suggestion: air temperature was essentially identical all year. The data on soil characteristics do show differences of $4^{\circ}$ and $6^{\circ}$ in annual extremes, but the means of the extremes were essentially identical. There is a difference in the 6 -inch soil-moisture data, but it is probably a sampling error. The depth of the humus-rich horizon varies greatly, and collected samples were sometimes humus-rich and sometimes humus-poor although they came from the same depth. All other factors were essentially the same at the two stations.

\section{b. Hairgrass Stand-Type}

The best development of true grass meadow in the alpine tundra is in the hairgrass (Deschampsia caespitosa (L.) Beauv.) stand. Farly ecologists emphasized the "grassland" character of the alpine tundra (Ramaley, 1919a, Cox, 1933), but this noun is appropriate only if used in the broadest possible sense and made to include the sedges (Carex spp.), for these relatives of the

true grasses are the real dominants of many tundra stands. Deschampsia, however, is a true grass, and it definitely dominates the aspect of this stand- 
TABle 26. D-2A Kobresia Meadow Stand Vegetation Data

\begin{tabular}{|c|c|c|c|c|c|c|c|c|c|c|c|c|c|c|c|}
\hline & \multicolumn{14}{|c|}{ Quadrat Number ( $3 \times 3$ feet) } & \multirow{2}{*}{ Freq. \% } \\
\hline & 1 & 2 & 3 & 4 & 5 & 6 & 7 & 8 & 9 & 10 & 11 & 12 & 13 & 14 & \\
\hline $\begin{array}{c}\text { Percentage of area covered } \\
\text { by plants } \ldots \ldots \ldots \ldots \ldots\end{array}$ & 100 & 95 & 95 & 95 & 85 & 90 & 99 & 95 & 85 & 95 & 85 & 97 & 95 & 99 & \\
\hline Geum rossii.... & $\mathbf{x}$ & $\mathrm{x}$ & $\mathrm{x}$ & $x$ & $\mathbf{x}$ & $\mathrm{x}$ & $\mathbf{x}$ & $\mathbf{x}$ & $\mathbf{x}$ & $\mathbf{x}$ & $\mathbf{x}$ & $\mathbf{x}$ & $\mathbf{x}$ & $\mathbf{x}$ & 100 \\
\hline Kobresia myosuroides. & $\mathbf{x}$ & $\mathrm{x}$ & $\mathrm{x}$ & $\mathbf{x}$ & $\mathrm{x}$ & $\mathrm{x}$ & $\mathrm{x}$ & $x$ & $\mathbf{x}$ & $\mathrm{x}$ & $\mathbf{x}$ & $\mathbf{x}$ & $\mathbf{x}$ & $\mathbf{x}$ & 100 \\
\hline Lloydia serotina. & $\mathrm{x}$ & $\mathbf{x}$ & $\mathbf{x}$ & $\mathrm{x}$ & $x$ & $\mathrm{x}$ & $\mathbf{x}$ & $\mathbf{x}$ & $\mathrm{x}$ & $\mathrm{x}$ & $x$ & $\mathrm{x}$ & $x$ & $x$ & 100 \\
\hline Oreoxis alpina. & $\mathbf{x}$ & $\mathbf{x}$ & $\mathbf{x}$ & $x$ & $\mathrm{x}$ & $\mathbf{x}$ & $\mathrm{x}$ & $\mathrm{x}$ & $\mathrm{x}$ & $\mathbf{x}$ & $\mathbf{x}$ & $\mathrm{x}$ & $\mathbf{x}$ & $\mathbf{x}$ & 100 \\
\hline Polygonum viviparum... & $\mathrm{x}$ & $\mathbf{x}$ & $\mathbf{x}$ & $\mathbf{x}$ & $x$ & $\mathbf{x}$ & $\mathrm{x}$ & $\mathbf{x}$ & $\mathrm{x}$ & $\mathbf{x}$ & $\mathrm{x}$ & $\mathbf{x}$ & $\mathrm{x}$ & $\mathbf{x}$ & 100 \\
\hline Carex scopulorum. & $\mathbf{x}$ & $\mathbf{x}$ & & $\mathbf{x}$ & $\mathbf{x}$ & $\mathbf{x}$ & $\mathrm{x}$ & $\mathbf{x}$ & $\mathrm{x}$ & $\mathrm{x}$ & $x$ & $\mathbf{x}$ & $\mathbf{x}$ & & 86 \\
\hline Trifolium dasyphyllum. & & $\mathbf{x}$ & $\mathrm{x}$ & & $\mathbf{x}$ & $\mathbf{x}$ & $\mathbf{x}$ & $\mathbf{x}$ & $\mathbf{x}$ & $\mathrm{x}$ & $x$ & $x$ & $\mathbf{x}$ & $x$ & 86 \\
\hline Campanula uniflora. & $\mathbf{x}$ & & & $\mathbf{x}$ & $\mathbf{x}$ & $\mathbf{x}$ & $\mathrm{x}$ & $\mathbf{x}$ & $x$ & & $x$ & $\mathbf{x}$ & $\mathbf{x}$ & $\mathbf{x}$ & 79 \\
\hline Poa arctica..... & & $\mathbf{x}$ & $\mathbf{x}$ & $\mathrm{x}$ & $\mathrm{x}$ & $\mathrm{x}$ & $\mathrm{x}$ & $\mathrm{x}$ & $\mathrm{x}$ & $\mathrm{x}$ & $\mathrm{x}$ & & $\mathbf{x}$ & & 79 \\
\hline Potentilla rubricaulis. & & & $\mathbf{x}$ & & $\mathbf{x}$ & $\mathbf{x}$ & $\mathbf{x}$ & $\mathrm{x}$ & $\mathrm{x}$ & $\mathrm{x}$ & $x$ & $\mathbf{x}$ & $\mathrm{x}$ & $\mathrm{x}$ & 79 \\
\hline Arenaria obtusiloba. & & $\mathbf{x}$ & $\mathbf{x}$ & $\mathbf{x}$ & $\mathrm{x}$ & $\mathbf{x}$ & & $\mathbf{x}$ & $\mathbf{x}$ & $\mathbf{x}$ & & & $\mathrm{x}$ & $\mathrm{x}$ & 71 \\
\hline Potentilla diversifolia. & & $\mathrm{x}$ & $\mathbf{x}$ & $\mathrm{x}$ & $\mathbf{x}$ & & & $\mathbf{x}$ & $\mathbf{x}$ & $\mathbf{x}$ & & $x$ & $\mathrm{x}$ & $\mathbf{x}$ & 71 \\
\hline Selaginella densa.... & & $\mathrm{x}$ & $\mathbf{x}$ & $\mathbf{x}$ & $\mathbf{x}$ & $\mathbf{x}$ & $\mathrm{x}$ & & $\mathrm{x}$ & $\mathbf{x}$ & $\mathbf{x}$ & $\mathbf{x}$ & & & 71 \\
\hline Oxyria digyna & & & & $\mathbf{x}$ & $\mathbf{x}$ & $\mathbf{x}$ & $\mathbf{x}$ & $\mathbf{x}$ & $\mathrm{x}$ & & $\mathbf{x}$ & $x$ & $\mathbf{x}$ & & 64 \\
\hline Trisetum spicatum. & & & $\mathbf{x}$ & $\mathrm{x}$ & $\mathrm{x}$ & & $\mathrm{x}$ & $\mathbf{x}$ & $\mathrm{x}$ & $\mathrm{x}$ & & $\mathrm{x}$ & $\mathrm{x}$ & & 64 \\
\hline Silene acaulis ..... & & $x$ & $\mathbf{x}$ & $\mathrm{x}$ & $x$ & & $\mathbf{x}$ & & $\mathbf{x}$ & & & $\mathbf{x}$ & & & 50 \\
\hline Castilleja occidentalis... & & $x$ & $\mathbf{x}$ & & $x$ & & $\mathbf{x}$ & $\mathbf{x}$ & $\mathbf{x}$ & & & & & & 43 \\
\hline Polygonum bistortoides... & $\mathbf{x}$ & $x$ & $\mathbf{x}$ & $\mathrm{x}$ & $\mathbf{x}$ & $\mathbf{x}$ & & & & & & & & & 43 \\
\hline Primula angustifolia.... & & & & & $\mathrm{x}$ & $\mathbf{x}$ & $\mathrm{x}$ & $\mathbf{x}$ & $\mathrm{x}$ & & & & & & 36 \\
\hline Erigeron simplex. . & $\mathrm{x}$ & & $\mathbf{x}$ & $\mathrm{x}$ & & & & & & & & & $x$ & & 29 \\
\hline Carex albonigra. & $\mathrm{x}$ & $\mathrm{x}$ & $\mathbf{x}$ & & & & & & & & & & & & 21 \\
\hline Eritrichium aretioides. & & & & $\mathrm{x}$ & & $\mathbf{x}$ & & & & $\mathrm{x}$ & & & & & 21 \\
\hline Heuchera parvifolia. & & & $\mathbf{x}$ & & & & & $\mathbf{x}$ & $\mathbf{x}$ & & & & & & 21 \\
\hline Saxifraga serpyllifolia. & & $\mathbf{x}$ & & & & $\mathbf{x}$ & $\mathbf{x}$ & & & & & & & & 21 \\
\hline
\end{tabular}

type. One stand on Niwot Ridge covers several acres. Hairgrass is a bunchgrass, but the bunches grow so close together in the sites most congenial for this species that at a distance the stand appears to be as continuous and uniform as a cultivated lawn that has not been mowed. Basal cover is actually only about $60 \%$, but the tops of the plants spread out over the bare ground between bunches. Geum rossii and Polygonum bistortoides Pursh are common in this stand.

There is actually a complex of stands in which hairgrass is conspicuous. Most of them have a cover of snow that develops early in the winter and remains at least until early summer and may persist until mid-summer. We have not yet worked out the details on each stand-type. The one described above is a climax under conditions of moderate snow cover. 
TABLE 27. Comparison of Four Stands in the Alpine Climax Region

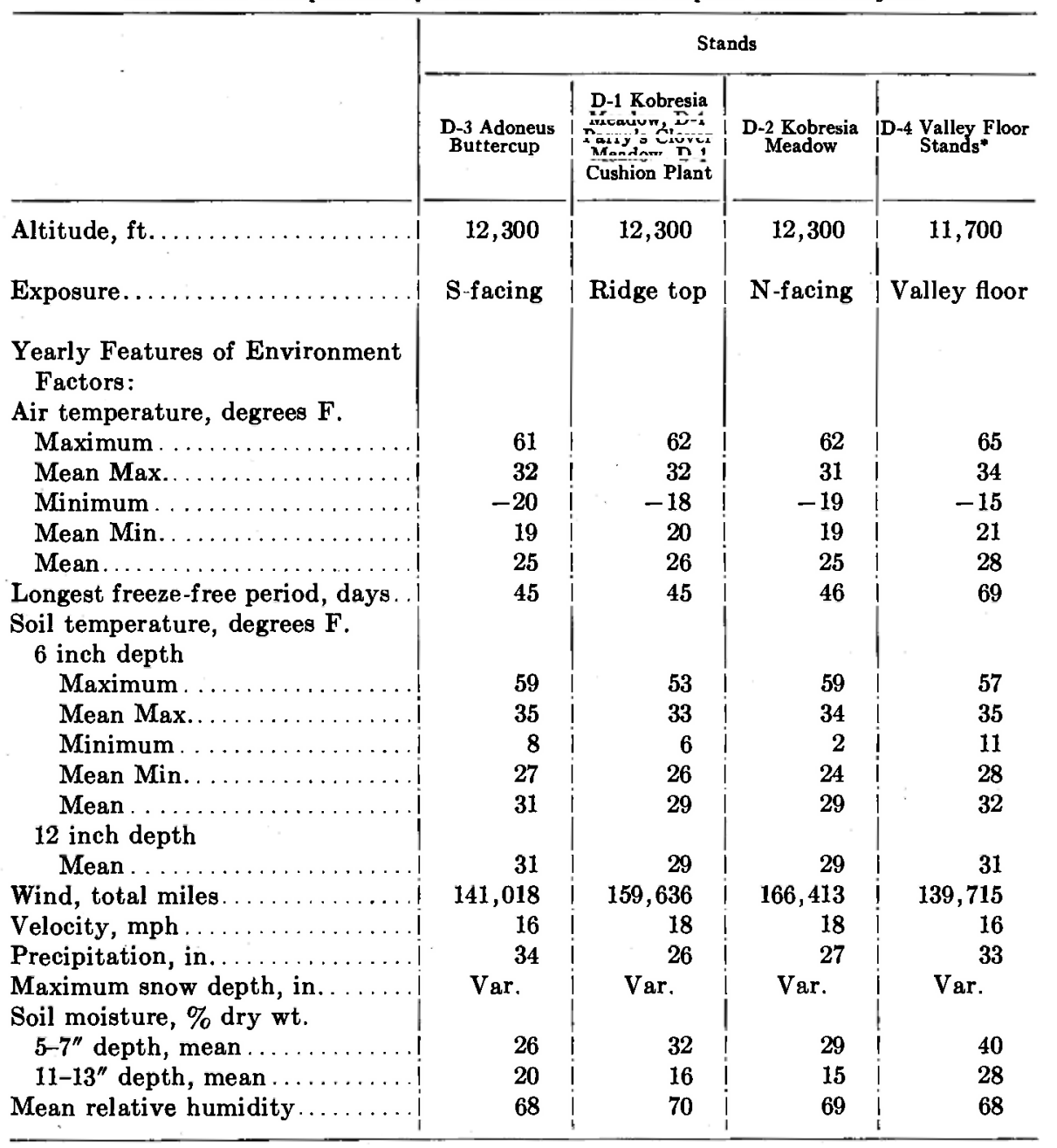

"This site was 600 feet lower than but the same distance from the Divide as the other three " $D$ " sites.

\section{c. Parry's Clover Meadow Stand-Type}

There is a series of stand-types whose character is determined largely by ecosystem processes and conditions controlled by snow accumulation which, in turn, is controlled by topography and wind. All sizes of depressions, and areas in the lee of topographic breaks, are sites of wind deposition of snow. Numerous factors control the time at which the snow melts, if at all, during 
the warm season. The duration of the growing season, and doubtless the character of several other environment features also, in different parts of the snow-accumulation area, tend to vary in concentric zones that conform roughly to the shape of the area. Consequently, there is a tendency for a concentric zonation of vegetation. In actual field situations, however, some other environment factors that do not vary symmetrically with the shape of the area appear to dominate in the environment complex because the pattern of stands often diverges from the more simple classical view of concentric zones.

Parry's clover (Trifolium parryi) meadow occurs in shallow depressions. Wind transport of the first snow of the fall fills them in and reveals the presence of many such depressions scattered across what had appeared to be level landscape all summer. This initial snow accumulation is usually dissipated by wind erosion, sublimation, and melting before the next storm deposits more snow. Eventually, accumulation exceeds dissipation of snow, and the depression fills up to near the general level of the land; thereafter snow blows right on across the site. Wind does scour out some of the snow between successive storms, but each new storm brings the level up again. This process of deposition and erosion goes on all winter with the maximum depth being only a few feet. Whatever snow is in the site at the onset of abovefreezing temperatures melts quickly. Much of the melt-water runs off the higher surfaces and accumulates as small pools in the bouldery depressions of the ancient sorted-net ground pattern. Frozen ground accounts for both the run-off and the ponding.

The fragrant pink flowers of Parry's clover delimit this stand clearly in the early part of the growing season. As Table 28 shows, however, Geum rossii, Polygonum bistortoides, and Artemisia scopulorum Gray are all common in this stand-type. These plants become more conspicuous after the clover flowers have wilted. The presence of kobresia in the samples of this stand results from the irregularity in the floor of the depression and the placement of sampling frames by the assistants collecting the data. The irregularities produce small hummocks that rise above the level of snow accumulation and support concentrations of kobresia. Irregularities in the outline of the stand resulted in inclusion of parts of the adjacent kobresia meadow in several samples.

The data above were collected in a stand, D-1B, about 50 feet southeast of the Tundra Laboratory. It is completely surrounded by kobresia meadow, and its external environment is essentially the same as that measured at Station D-1. This stand appears to be relatively stable and could be called a shallow-depression climax. 
TABLE 28. D-1B Parry's Clover Meadow Stand Vegetation Data

\begin{tabular}{|c|c|c|c|c|c|c|c|c|c|}
\hline & \multicolumn{8}{|c|}{ Quadrat Number $(3 \times 3$ feet $)$} & \multirow{2}{*}{ Freq. \% } \\
\hline & 1 & 2 & 3 & 4 & 5 & 6 & 7 & 8 & \\
\hline Percentage of area covered by plants. & 95 & 90 & 85 & 90 & 85 & 85 & 85 & 70 & \\
\hline Artemisia scopulorum $\ldots \ldots \ldots \ldots$ & $\mathbf{x}$ & $\mathrm{x}$ & $\mathrm{x}$ & $\mathrm{x}$ & $\mathrm{x}$ & $\mathrm{x}$ & $\mathbf{x}$ & $x$ & 100 \\
\hline Geum rossii $\ldots \ldots \ldots \ldots \ldots \ldots \ldots$ & $\mathbf{x}$ & $\mathrm{x}$ & $\mathbf{x}$ & $\mathrm{x}$ & $\mathbf{x}$ & $x$ & $\mathbf{x}$ & $\mathrm{x}$ & 100 \\
\hline Kobresia myosuroides.......... & $\mathrm{x}$ & $\mathrm{x}$ & $\mathrm{x}$ & $\mathbf{x}$ & $\mathbf{x}$ & $\mathbf{x}$ & $\mathrm{x}$ & $\mathbf{x}$ & 100 \\
\hline Selaginella densa $\ldots \ldots \ldots \ldots \ldots$ & $\mathbf{x}$ & $\mathbf{x}$ & $\mathrm{x}$ & $\mathrm{x}$ & $\mathrm{x}$ & $\mathbf{x}$ & $\mathbf{x}$ & $\mathrm{x}$ & 100 \\
\hline Trifolium parryi $\ldots \ldots \ldots \ldots \ldots \ldots$ & $\mathbf{x}$ & $\mathrm{x}$ & $\mathbf{x}$ & & $\mathrm{x}$ & $\mathbf{x}$ & $\mathbf{x}$ & $\mathrm{x}$ & 88 \\
\hline Polygonum bistortoides . . . . . . . & $\mathrm{x}$ & $\mathrm{x}$ & $\mathrm{x}$ & $\mathrm{x}$ & $\mathrm{x}$ & & $\mathrm{x}$ & & 75 \\
\hline Carex seopulorum $\ldots \ldots \ldots \ldots \ldots$ & $\mathrm{x}$ & & $x$ & $\mathrm{x}$ & $\mathrm{x}$ & $\mathbf{x}$ & $x$ & & 75 \\
\hline Silene acaulis $\ldots \ldots \ldots \ldots \ldots \ldots$ & $\mathrm{x}$ & $x$ & $\mathbf{x}$ & & & $x$ & & $\mathbf{x}$ & 62 \\
\hline Gentiana romanzovij . . . . . . . . . . & & & $\mathbf{x}$ & $x$ & & & $\mathbf{x}$ & $\mathbf{x}$ & 50 \\
\hline Polygonum viviparum $\ldots \ldots \ldots \ldots$ & & & $\mathbf{x}$ & $\mathbf{x}$ & & $\mathbf{x}$ & $\mathbf{x}$ & & 50 \\
\hline Salix reticulata var. nivalis . . . . . . & & & $\mathbf{x}$ & $\mathbf{x}$ & $\mathbf{x}$ & & $\mathbf{x}$ & & 50 \\
\hline Saxifraga rhomboidea $\ldots \ldots \ldots \ldots$ & $\mathrm{x}$ & $\mathbf{x}$ & $\mathbf{x}$ & & & $\mathbf{x}$ & & & 50 \\
\hline Arenaria obtusiloba $\ldots \ldots \ldots \ldots$ & & & & & $\mathrm{x}$ & $x$ & & $\mathrm{x}$ & 38 \\
\hline Carex rupestris . . . . . . . . . . & & $x$ & $\mathrm{x}$ & & & & $\mathbf{x}$ & & 38 \\
\hline Erigeron simplex............. & $\mathbf{x}$ & & & & & $\mathbf{x}$ & & $\mathrm{x}$ & 38 \\
\hline Poa arctica..$\ldots \ldots \ldots \ldots \ldots \ldots$ & & $\mathbf{x}$ & $\mathrm{x}$ & & $\mathrm{x}$ & & & & 38 \\
\hline Sedum lanceolatum $\ldots \ldots \ldots \ldots \ldots$ & & $\mathbf{x}$ & $\mathrm{x}$ & & & $\mathbf{x}$ & & & 38 \\
\hline Carex athrostachya .............. & & & & & & $\mathbf{x}$ & $\mathrm{x}$ & & 25 \\
\hline Draba crassifolia . . . . . . . . . . & $\mathrm{x}$ & $\mathrm{x}$ & & & & & & & 25 \\
\hline Phlox pulvinata . . . . . . . . & & & $\mathrm{x}$ & & & $\mathbf{x}$ & & & 25 \\
\hline Sedum rosea $\ldots \ldots \ldots \ldots \ldots \ldots$ & & & $\mathrm{x}$ & $\mathbf{x}$ & & & & & 25 \\
\hline Trifolium dasyphyllum $\ldots \ldots \ldots \ldots$ & & & & $\mathbf{x}$ & & & $\mathbf{x}$ & & 25 \\
\hline Lewisia pygmaea. & & & & & & & $\mathbf{x}$ & $\mathrm{x}$ & 25 \\
\hline Lichens......... & & $\mathrm{x}$ & $\mathrm{x}$ & $\mathbf{x}$ & & & & & 38 \\
\hline Mosses... & $\mathbf{x}$ & $\mathbf{x}$ & & $\mathrm{x}$ & $\mathbf{x}$ & & $\mathrm{x}$ & & 62 \\
\hline Puffballs. & & & $\mathbf{x}$ & $\mathbf{x}$ & & & & & 25 \\
\hline
\end{tabular}

Note: Eight other species with a frequency of less than 20 per cent are included in the syecies list in Appendix I.

\section{d. Adoneus Buttercup Stand-Type}

Sites with somewhat greater topographic relief than those of Parry's clover stands hold snow earlier and lose it later and have an environment that permits adoneus buttercup (Ranunculus adoneus Gray) to develop in abundance. The resulting stands are made conspicuous in early summer by the brilliant yellow flowers of the buttercup, which of ten pushes its flower stems up through a thin layer of rotten snow and spreads out its petals against the white background. As the season progresses, growth of other plants obscures the buttercup.

We studied an adoneus buttercup stand, Stand D-3A, on the south-facing 
TABLE 29. D-3A Adoneus Buttercup Stand Vegetation Data

\begin{tabular}{|c|c|c|c|c|c|c|c|c|c|c|c|c|c|}
\hline & \multicolumn{12}{|c|}{ Quadrat Number $(3 \times 3$ feet) } & \multirow{2}{*}{ Freq. \% } \\
\hline & 1 & 2 & 3 & 4 & 5 & 6 & 7 & 8 & 9 & 10 & 11 & 12 & \\
\hline 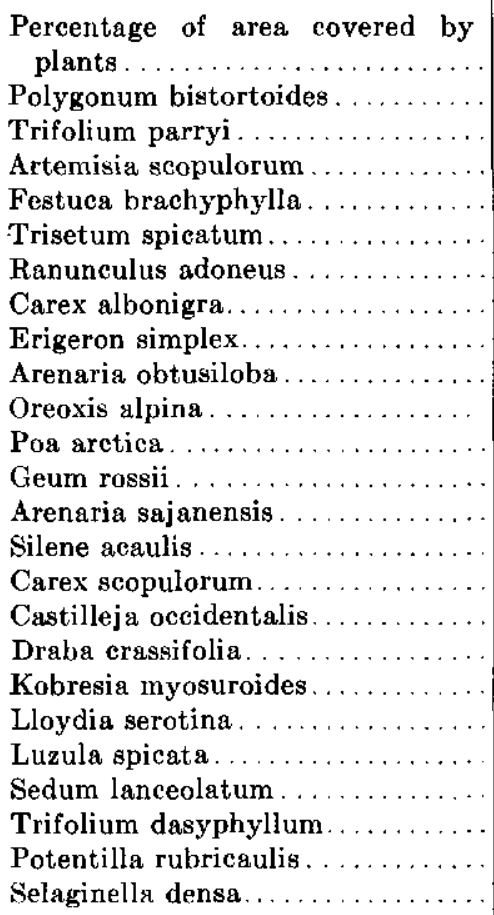 & $\begin{array}{l}80 \\
x \\
x \\
x \\
x \\
x \\
x \\
x\end{array}$ & $\begin{array}{c}85 \\
\mathrm{x} \\
\mathrm{x} \\
\mathrm{x} \\
\mathrm{x} \\
\mathrm{x} \\
\mathrm{x} \\
\mathrm{x} \\
\mathrm{x}\end{array}$ & $\begin{array}{l}93 \\
\mathrm{x} \\
\mathrm{x} \\
\mathrm{x} \\
\mathrm{x} \\
\mathrm{x} \\
\mathrm{x}\end{array}$ & $\begin{array}{c}85 \\
x \\
x \\
x\end{array}$ & $\begin{array}{l}85 \\
x \\
x \\
x \\
x \\
x \\
x \\
x\end{array}$ & \begin{tabular}{|c|c|}
85 \\
$x$ \\
$x$ \\
$x$ \\
$x$ \\
$x$ \\
$x$ \\
$x$ \\
$x$ \\
$x$ \\
\\
$x$ \\
$x$ \\
$x$ \\
$x$ \\
\\
$x$ \\
\\
$x$ \\
$x$ \\
$x$ \\
$x$ \\
$x$ \\
$x$
\end{tabular} & \begin{tabular}{|c}
$x$ \\
$x$ \\
$x$ \\
$x$ \\
$x$ \\
$x$ \\
$x$ \\
$x$ \\
$x$ \\
$x$ \\
$x$ \\
$x$ \\
$x$
\end{tabular} & $\begin{array}{c}70 \\
x \\
x \\
x \\
x \\
x \\
x \\
\\
x \\
x \\
x \\
\\
x \\
x\end{array}$ & $\begin{array}{c}75 \\
x \\
x \\
x \\
x \\
\\
x \\
x \\
x \\
x \\
x \\
x\end{array}$ & \begin{tabular}{|c|}
82 \\
$x$ \\
$x$ \\
$x$ \\
$x$ \\
$x$ \\
$x$ \\
$x$ \\
$x$ \\
$x$ \\
$x$ \\
\\
$x$ \\
$x$ \\
$x$ \\
\\
$x$ \\
$x$ \\
$x$ \\
$x$ \\
$x$
\end{tabular} & $\begin{array}{c}80 \\
x \\
x \\
x \\
x \\
x \\
x\end{array}$ & $\left(\begin{array}{l}70 \\
x \\
x \\
x \\
x \\
x\end{array}\right.$ & $\begin{array}{r}100 \\
100 \\
92 \\
92 \\
83 \\
58 \\
58 \\
58 \\
58 \\
58 \\
58 \\
58 \\
50 \\
42 \\
33 \\
33 \\
33 \\
33 \\
33 \\
33 \\
33 \\
33 \\
25 \\
25\end{array}$ \\
\hline
\end{tabular}

Note: Eleven other speciea which had a frequency below 20 per cent are included in the species list in Appendix I.

slope $(16 \%)$ of Niwot Ridge near Station D-3 only about 30 feet below the ridge top in altitude. Table 29 gives data on the vegetation and shows that Festuca and Artemisia scopulorum are abundant in this stand along with the more conspicuous species. This was an irregular-shaped stand, and several of the quadrants that contained kobresia were probably overlapping adjacent stands.

Data from Station D-3 give information on the external environment of the adoneus buttercup stand; Table 24 gives soil data. Comparisons of the environment of Stations D-2 and D-3 (Table 27) are of interest because they were at the same altitude but on opposite slopes of the ridge. Air temperature, air humidity, the length of the freeze-free period, and soil temperature 
were the same at the two stations. D-3 had less wind and, as a result, more precipitation because there is more wind from the northwest and therefore more eddying over D-3. The interrelations of wind and the precipitation sample caught in a gauge discussed above for station D-1 are illustrated again by comparison of D-2 and D-3. The gauge at the latter station received 9 inches more precipitation; comparison of monthly figures shows that the largest differences in precipitation came during the windiest months, the maximum of both features being in January.

\section{e. Snowbank Complex}

As the magnitude of topographic relief increases beyond that of the preceding stands, snow accumulates still earlier and leaves still later and produces additional types of stands. Dahl (1956), Gjaerevoll (1956), and Billings and Bliss (1959) have described these ecosystem complexes.

If the ground first exposed by snow melt is fairly well drained, but is moist, lush sedges and grasses dominate. From this area inward to the site of the last-melting snow, there may be a progressive decrease in the size and density of plants and a progressive change in species. A lichen-moss community occurs on the ground that is the last to be exposed by the melting snow in some sites. Sibbaldia procumbens $\mathrm{L}$. dominates many late-snow stands.

If the ground first exposed by the melting snow is poorly drained, congeliturbation keeps the soil so disturbed that only a sparse cover of specialized plants can develop. The more active centers of "frost-churning" are bare.

\section{f. Cushion Plant Stand-Type}

Ground surfaces that are tipped only a few degrees toward the prevailing westerly winds are subject to strong wind and little or no snow cover. The more severe the wind, the more adverse the environment. Snow that falls on these sites is blown away, often forming moving dunes soon after it falls. Plants and soil are, therefore, exposed to severe dessication the year around. Several species of cushion plants (moss campion, sandwort, and alpine forgetme-not) are most abundant in this stand. In the less severe sites of this habitat-type, Geum, a bunch-plant, is abundant. This is a topographic-climax type. One stand of this type just west of station D-1, Stand D-1C, was studied in detail. Table 30 gives data on the vegetation.

\section{g. Dryas Stand-Type}

In areas of gentle slope, relatively fine soil material, and abundant moisture in the spring, the soil moves down slope in a slow mass-wasting process as the soil particles are stirred and heaved by frost. On Niwot Ridge, the best exam- 
TABLE 30. D-1C Cushion Plant Stand Vegetation Data

Percentage of area covered by plants. Arenaria obtusiloba...

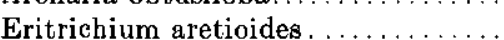

Lloydia serotina. . . . . . . . . . . .

Oreoxis alpina.

Paronychia sessiliflora ssp. pulvinata.

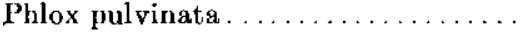

Trifolium nanum. . . . . . . . . . .

Arenaria fendleri . ................

Calamagrostis purpurascens . . ......

Carex rupestris.

Geum rossii ...

Kobresia myosuroides $\ldots \ldots \ldots \ldots \ldots$

Poa arctica....................

Selaginella densa ...............

Trisetum spicatum . . . . . . . . . . .

Erigeron simplex . . . . . . . . . . . .

Mertensia viridis . ...............

Primula angustifolia.............

Ijichens .

\begin{tabular}{|c|c|c|c|}
\hline \multicolumn{3}{|c|}{ Quadrat Number ( $3 \times 3$ feet $)$} & \multirow{2}{*}{ Freq. $\%$} \\
\hline 1 & 2 & 3 & \\
\hline- & 90 & 80 & \\
\hline$x$ & $\mathbf{x}$ & $\mathrm{x}$ & 100 \\
\hline$x$ & $x$ & $\mathrm{x}$ & 100 \\
\hline $\mathrm{x}$ & $\mathrm{x}$ & $\mathrm{x}$ & 100 \\
\hline $\mathrm{x}$ & $\mathrm{x}$ & $\mathrm{x}$ & 100 \\
\hline $\mathbf{x}$ & $\mathbf{x}$ & $\mathbf{x}$ & 100 \\
\hline $\mathrm{x}$ & $\mathbf{x}$ & $\mathbf{x}$ & 100 \\
\hline $\mathbf{x}$ & $\mathrm{x}$ & $\mathrm{x}$ & 100 \\
\hline $\mathrm{x}$ & $x$ & & 67 \\
\hline $\mathrm{x}$ & $\mathrm{x}$ & & 67 \\
\hline $\mathbf{x}$ & & $\mathbf{x}$ & 67 \\
\hline $\mathrm{x}$ & $\mathbf{x}$ & & 67 \\
\hline \multirow[t]{3}{*}{$\mathrm{x}$} & $\mathrm{x}$ & & 67 \\
\hline & $\mathbf{x}$ & $\mathbf{x}$ & 67 \\
\hline & $\mathrm{x}$ & $\mathbf{x}$ & 67 \\
\hline $\mathrm{x}$ & & $\mathbf{x}$ & 67 \\
\hline $\mathrm{x}$ & & & 33 \\
\hline & $\mathbf{x}$ & & 33 \\
\hline & & $\mathbf{x}$ & 33 \\
\hline $\mathbf{x}$ & $\mathbf{x}$ & $\mathbf{x}$ & 100 \\
\hline
\end{tabular}

ple of this environment type is also exposed to strong wind. Mats of the dryad, Dryas octopetala ssp. hookeriana (Juz.) Hulten, form obstructions to the soil movement and produce small terraces ("dryas-banked terraces"). There are few other flowering plants in the community. This is a topoedaphic-climax stand-type.

\section{h. Sedge-Grass Wet Meadow Stand-Type}

A really lush meadow of sedges with an admixture of grasses occurs on colifluction terraces where the soil is kept wet or moist all summer by ground water. The plants are over 10 inches tall, and they form a dense sward that is broken only by occasional openings. Often the plants form a relatively impervious dam around plant-free areas and produce small ponds while the soil is frozen almost to the surface and water is abundant. As the soil thaws out and underground drainage develops, the ponds usually dry up. Mineral soil material of fine texture has accumulated to depths of over 6 feet in these sites, and the vigorous plant growth has contributed an abundance of humus which makes a soil that is very black in the upper horizon and brown for 
many inches below the black. Freeze-thaw processes have produced a layer of stones on the bottom of the ponds that gives an erroncous impression of a rocky soil. This stand-type is most common at lower elevations in the tundra, perhaps because most higher levels lack sufficient water to support them.

We have found soil ice in these stands throughout the summer at progressively greater depth as the summer advanced. These observations suggest that permanent ice, "permafrost", may occur in these stands if solid bedrock is not reached in 10 feet.

This is a climax stand, for it will persist with little change as long as climate and physiography remain the same.

\section{i. Willow-Sedge Hummock Stand-Type}

Sites with very low slope gradient, wet soil throughout the summer, and light snow cover that melts early in the warm season are dominated by hummocky topography and vigorous low willows and sedges. Hummocks are up to 3 feet in diameter and 18 inches high. Inter-hummock depressions may be small basins or interconnected channels of varying length. They are water-filled during early summer and rarely have more than a thin cover of small plants. Individual hummocks may become elevated above the general stand level, probably by the concentration of ice under them in the soil; in such an event, small parts of the dense plant cover are raised into the full blast of the dry winter wind that desiccates and kills the plants and eventually blows them away and begins to erode the mineral soil. Field observations suggest that, once the plant cover is broken through, needle-ice joins the eroding forces by breaking up the margins of the vegetation and thus enlarging the bare area. Such bare areas are probably often confused with "frost boils", a term more commonly applied to bare areas produced by actual convective movements and horizontal sorting of materials in the soil to a depth much greater than that involved in needle-ice activity. Eventually erosion lowers the top of a given mound to below the eroding plane, and revegetation soon overcomes the forces of erosion. In the stand as a whole, there are all stages in the sequence of the formation and revegetation of these small bare spots. It appears to be the type of process referred to by Watt (1947) as upgrade and downgrade succession and perhaps is the same as is outlined by Billings and Mooney (1959). The type is a topoedaphic climax. Reports by Retzer suggest that this stand-type may have permafrost at some depth in the soil. 


\section{j. Tundra Valley Stands}

Valleys in the alpine tundra generally have precipitous slopes, abundant lakes and snowfields, some glacially polished bedrock surfaces, rounded rock knolls sculptured by glacial ice, an occasional boulder left perched on smaller stores by melting glacial ice, and relatively lush vegetation. These beautiful and spectacular areas were not studied in detail in this project, but many observations were made and environment-measurement station number D-4 was operated for two years in the Green Lakes Valley. The valley contains many types of stands, some that are probably peculiar to valleys and others that have stands on ridges also. One type is that of spruce and fir tree islands that are topographic climaxes in the lee of boulders and rock knobs. The D-4 station was located in a sedge meadow near Green Lake Four. This site was about 600 feet lower than the other tundra stations but was directly below them and therefore permits comparisons of a topographic transect of stations all located the same distance from the Divide. It would have been impractical to place the valley station at the same altitude as the ridge stations because of problems in logisties.

Species composition of the vegetation around D-4 is given in Appendix I; the annual summary of environment is in Appendix II; soil data are in Table 24.

Comparisons of the D-4 valley site with the D-1 ridge-top site (Table 27) are interesting because the latter is directly upslope from the former. Air temperatures were $2^{\circ}$ or $3^{\circ}$ lower, soil temperatures were $2^{\circ}$ to $5^{\circ}$ lower, and the freeze-free period was 24 days shorter at the ridge-top site. The wind averaged two m.p.h. higher at the ridge, and the ridge received 7 inches less precipitation, possibly as a direct result of the greater amount of wind. Soil moisture was significantly higher in the valley, and humidity was not significantly different. 
Plate I

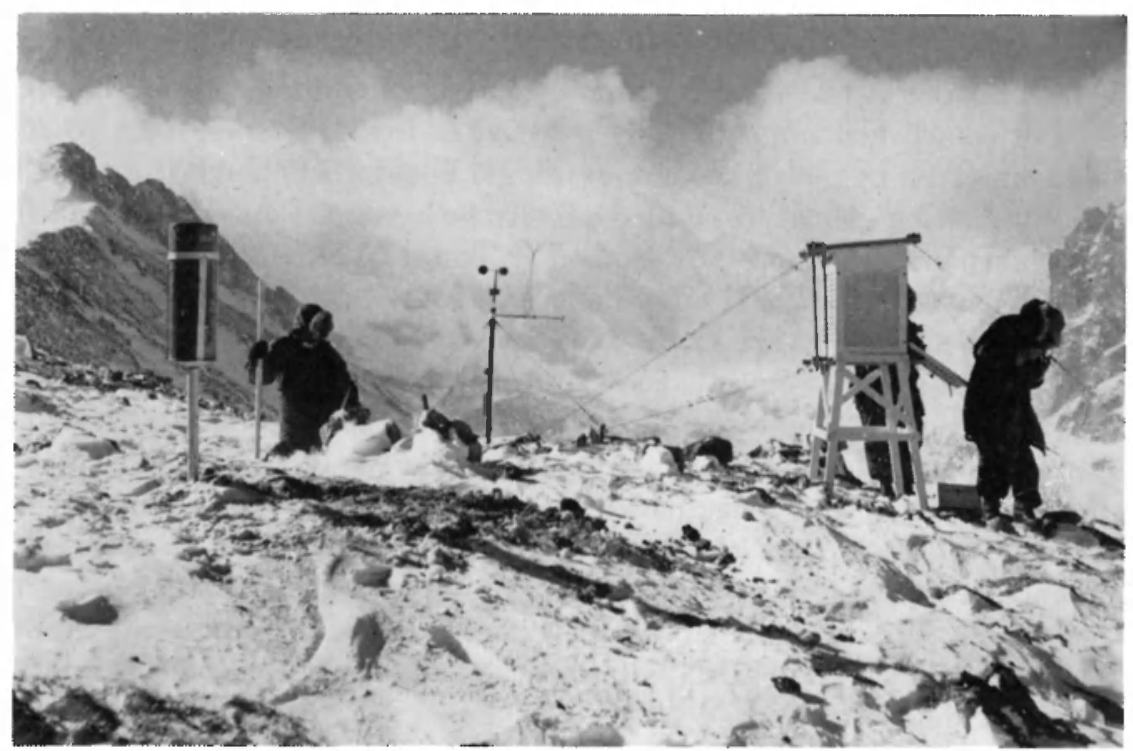

A. Environment-measurement station D-2 on Niwot Ridge.

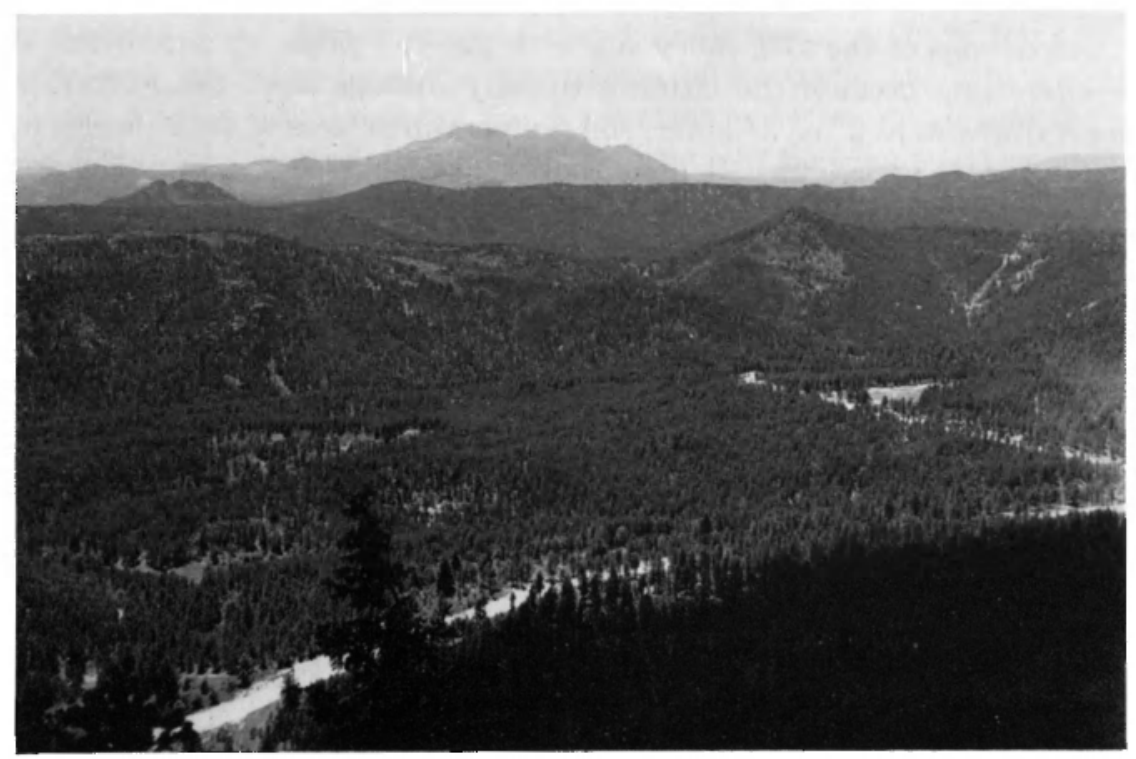

B. Looking southward across montane landscape from B-1 Station near Sugarloaf Mountain. Generally concordant and rolling surfaces make up the "Rocky Mountain surface" at altitudes of approximately 8,300 to 9,300 feet. 
Plate ?

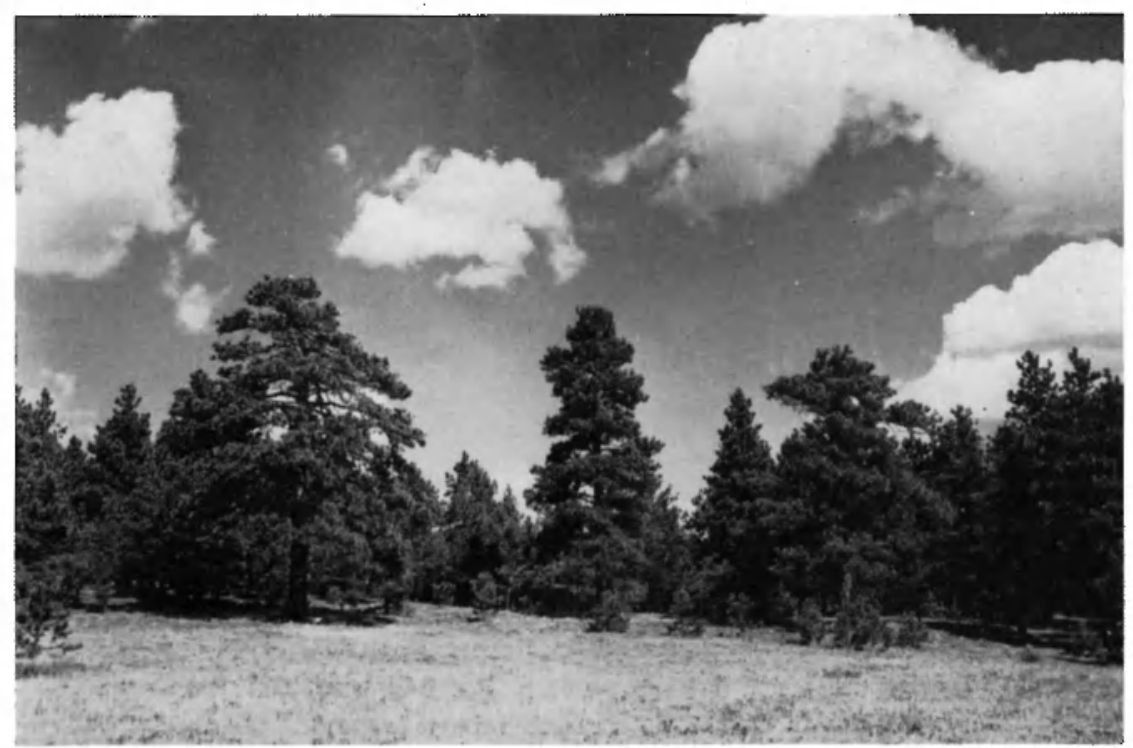

A. Ponderosa pine stand near A-1 Station in lower montane climax region. Dry grassland stand in foreground. Larger trees, whose flattened crowns indicate maturity, are about 30 feet tall.

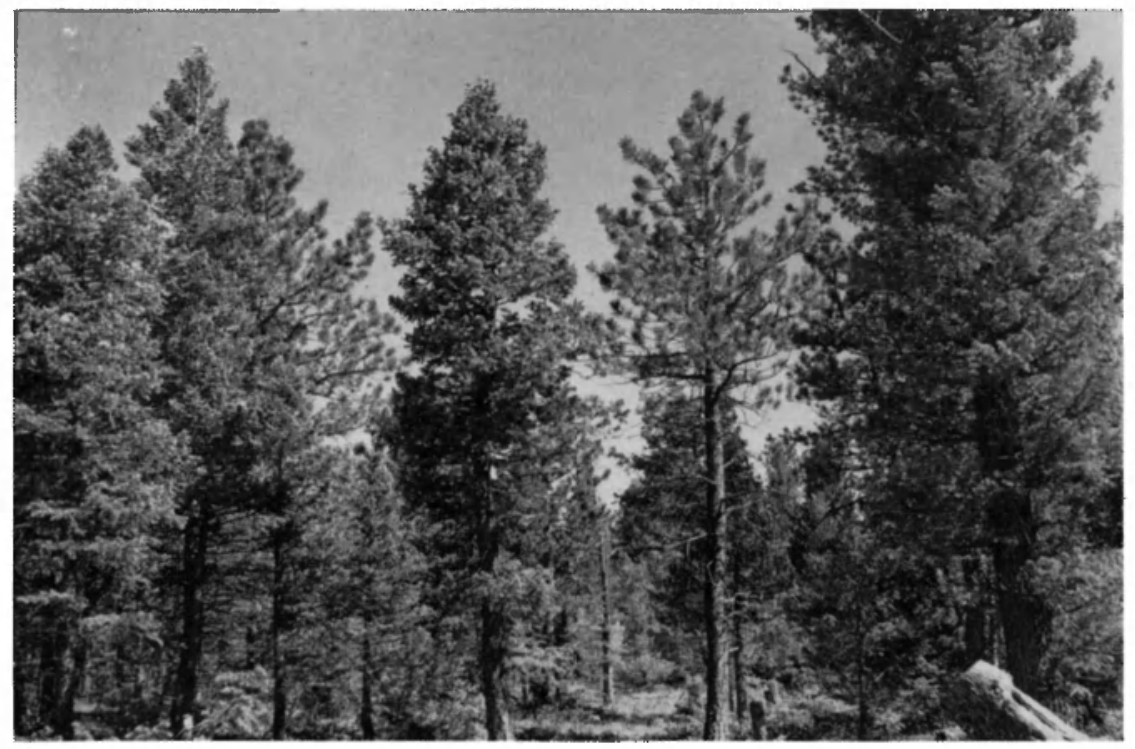

B. Douglasfir-ponderosa pine stand near B-1 Station. Larger treees, about 45 feet tall, are Douglasfir on left and ponderosa pine on right. 
Plate 3

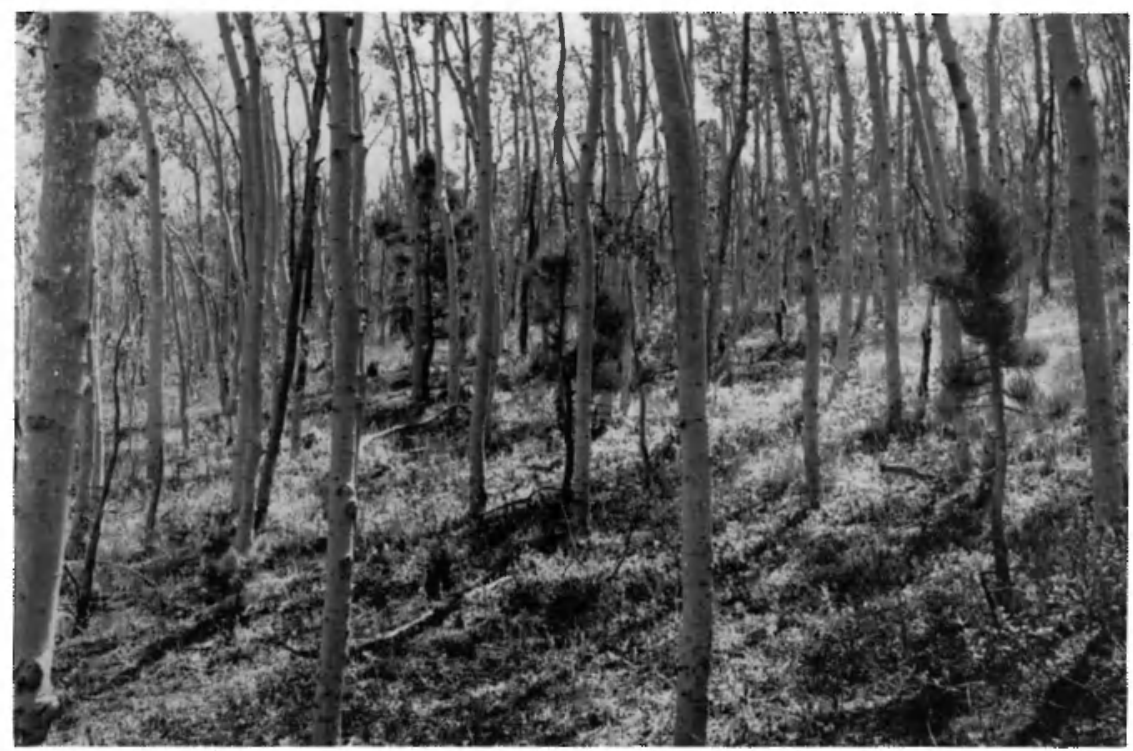

A. Aspen stand with ponderosa pine saplings that show tendency for succession from aspen to the pine. Trees are about 6 inches in diameter.

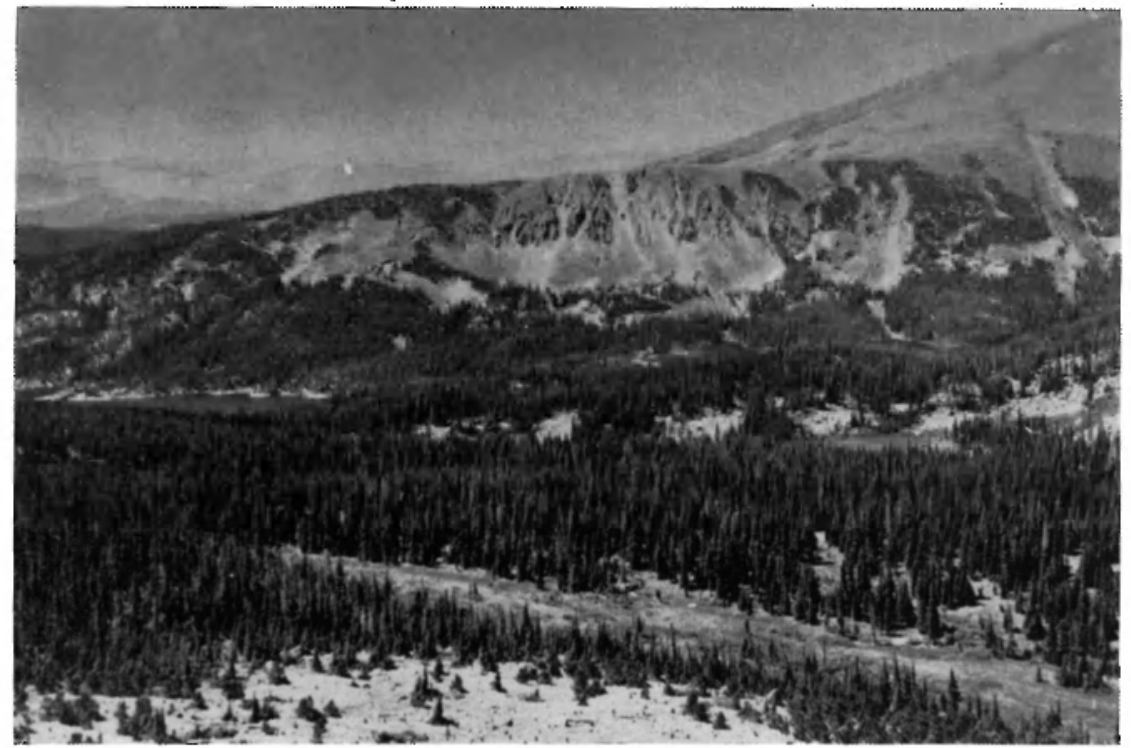

B. Spruce-fir stand of subalpine region in Silver Lake Valley. Tallest trees are 75 feet tall. Upper limits of the subalpine and parts of the forest-tundra ecotone in background are treeless because of either deep snow accumulation or steep topography. Alpine tundra in upper right. 
Plate 4

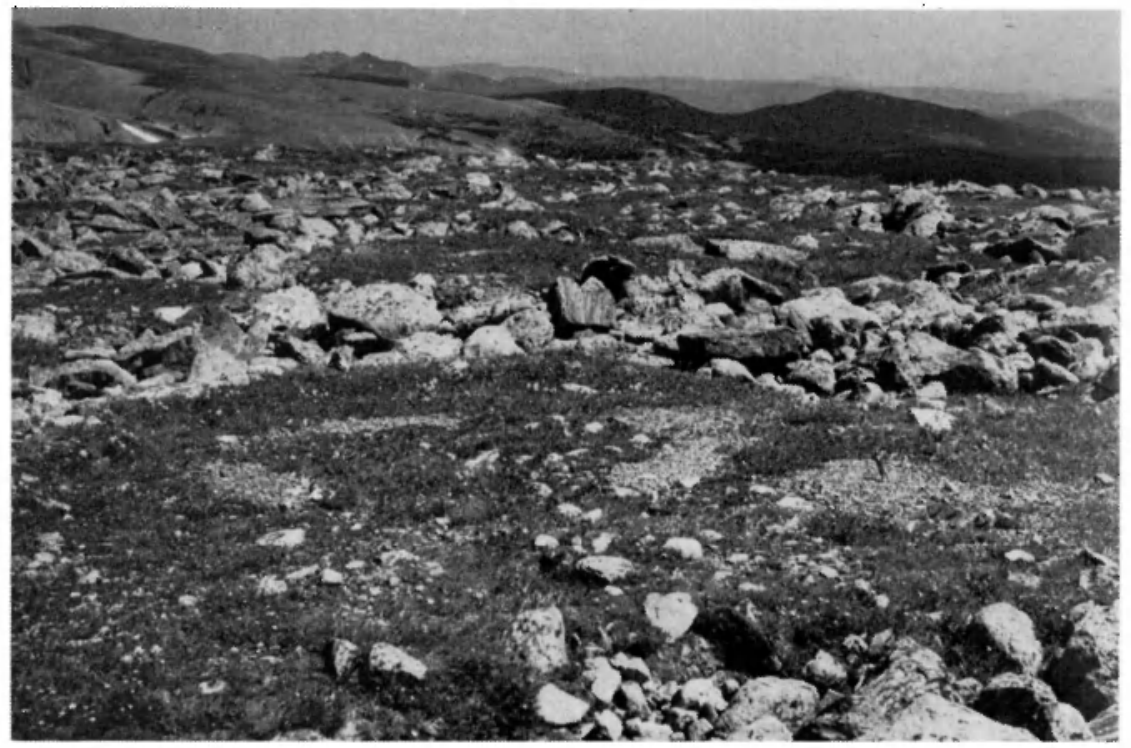

Patterned ground in alpine tundra on Niwot Ridge. Large pattern with boulder net is stable, while the small frost boils inside the larger pattern are active. Pocket knife in frost boil to right for scale. 


\section{Plate 5}

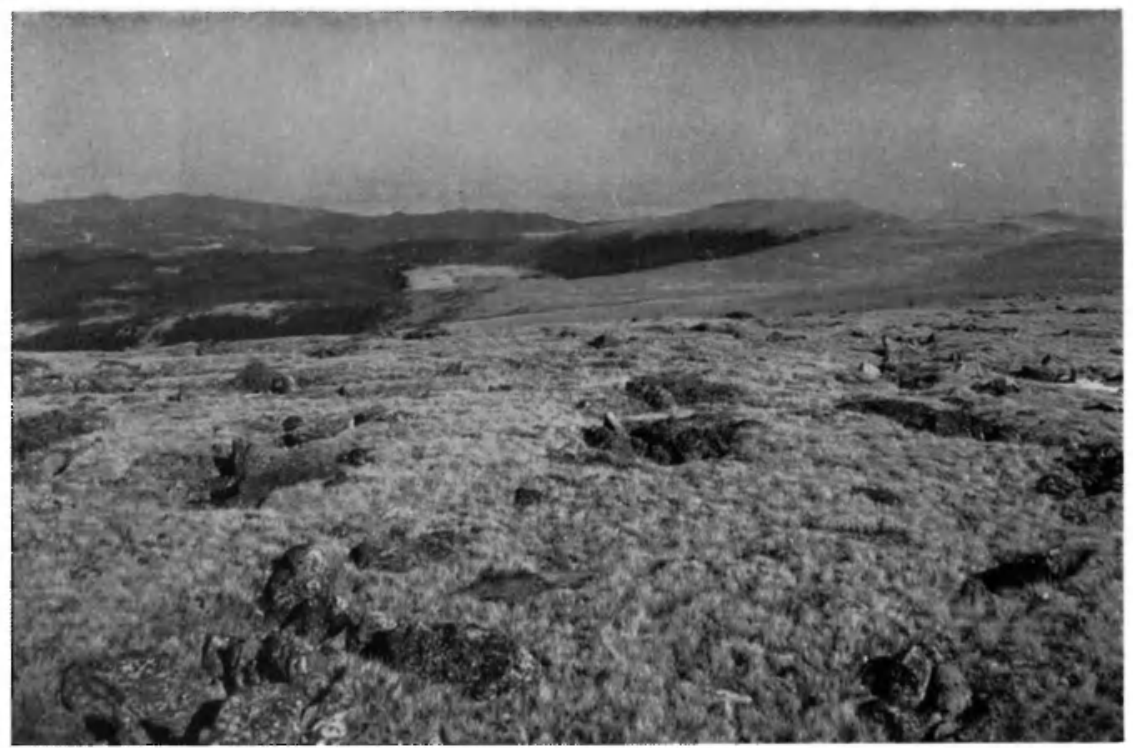

A. Kobresia meadow near D-1 Station on Niwot Ridge in early fall. Patterned ground processes have produced concentrations of boulders.

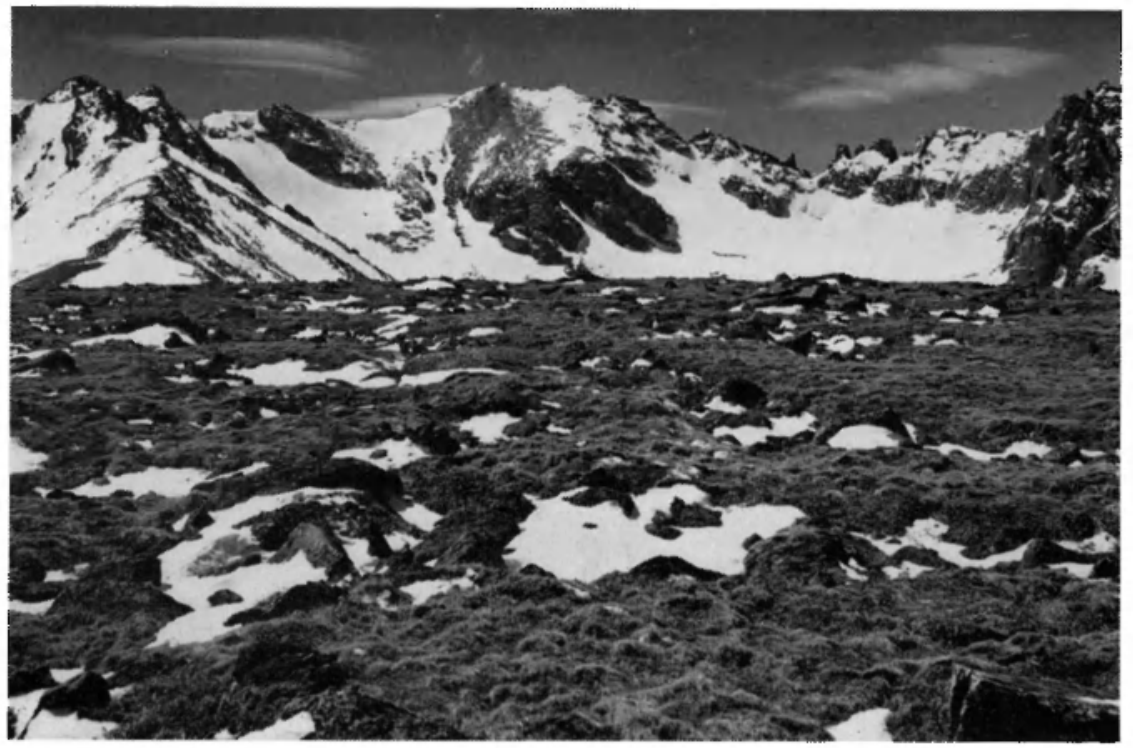

B. Kobresia meadow near D-1 Station in winter. Pockets of snow occupy depressions with either lichen-covered boulders or Parry's Clover meadow. 


\section{SUMMARY}

The east slope of the Front Range in north-central Colorado rises over a mile in altitude above the Great Plains in a horizontal distance of less than 20 miles. Atmospheric factors impinging on horizontal surfaces vary with changing altitudes. At any one altitude differences in topography and soil parent material produce differences in exposure to solar radiation and to wind, angle of slope, soil depth, and soil water. Most of the landscape has been altered more or less by processes initiated by fires, miners, lumbermen, farmers, cattle, and sheep. The rate and direction of ecological changes following these alterations have varied from place to place. These variations in environment factors, landscape alterations, and ecological processes have produced many different types of environments. Most of the plant species and probably many of the animals available to this area have ecological-amplitudes that limit them to one or a few of these environments. The natural consequence is a mosaic of many kinds of landscape units that differ in size, shape, and assortment of components.

Seventeen years of research and teaching in this area have revealed that the plant ecology of this complex mosaic can be studied and described effectively by employing the ecosystem concept and three types of ecosystem units: stand, stand-type, and region (climax and ecotone). The myriad of individual concrete field units are stands. All similar stands may be grouped into a single stand-type, and stand-types may, in turn, be grouped into regions. Stands may be successional or climax, the former being relatively transitory, and the latter being relatively stable in total character for a period of time that excecds the average life span of individuals of the longest-lived species in the stand. Climax stands that are "moderate" in total character, i.e., occur on horizontal to gently rolling topography, are exposed to intermediate intensities of regional atmospheric factors, and have relatively stable soils that are moderate in physicul, ehemical, and water features, are called climatic climaxes. An extensive geographie area with a single pattern of climaxes, or, to state it in another way, a region within which there is a single climaticclimax stand-type (real or potential), is a climax regiom. A smaller area of intermediate character between two adjacent climax regions is an ecotome regiom. There are 4 climax regions, 4 ecotone regions, a large number of standtypes, and a much larger number of stands on the east slope of the Front Range.

Each stand hus an internal and an external environment. The latter lies immediately outside the space in which environment is influenced by the 
plants that make up the stand; it is relatively constant during one climatic interval for a given site and does not change even if the vegetation changes.

Many stands of each stand-type were visited in the field during the 17 years of this study. Several environment factors were measured in such a way as to approximate the external stand environment of 16 different stands from 1 October, 1952, to 30 September, 1953. The present paper gives information on some characteristics of the 4 climax regions and the most conspicuous stands in each region.

The primary contribution of the environment data to ecology is that of providing numerical data on external environment factors of the major standtypes and regions. However, the following general comparisons are of interest:

a. Comparison of regional environments of adjacent climax regions reveals that the least difference was between the lower and upper montane, the latter having air temperatures $4^{\circ}$ to $7^{\circ}$ lower, soil temperatures $3^{\circ}$ to $8^{\circ}$ lower, $30 \%$ shorter freeze-free period, and about the same amount of precipitation and wind; the greatest difference was between the subalpine and alpine, the alpine having $9^{\circ}$ to $19^{\circ}$ lower soil temperatures, one half as long freezefree period, and twice as much wind. The general nature of these differences was anticipated on the basis of differences in the species and growth forms of the conspicuous plants in the different regions.

b. From one region to the next higher region, air and soil temperatures, the freeze-free period, and relative humidity decreased, while snow depth and duration increased. Precipitation, wind, and soil moisture differed little between the lower and upper montane but increased between the remaining pairs of regions. Precise comparisons of annual precipitation between regions are impossible because the amount of wind affects the magnitude of the sample of actual precipitation caught in a gauge, and the amount of wind varies greatly between the upper three regions. The data suggest, however, that actual annual precipitation increased with rising altitude throughout the study area during 1952-1953.

c. There was a conspicuous difference between ridge-top and south-facing stands in the forest regions where the south-facing units had less wind, more precipitation, and higher winter soil temperatures; in the tundra, the same differences were evident except for temperature.

d. Differences between north-facing and south-facing stands were conspicuous in the montane where stand-types are also very different on the two exposures, and relatively slight in the other regions where stand-types are not so obviously related to exposure. In both the lower and upper montane, air and soil temperatures were lower and snow cover was decper and lasted longer in north-facing stands. In the subalpine, higher maximum soil temperatures 
in the south-facing stand was the only conspicuous difference; in the alpine, more wind and less precipitation in the north-facing stand were the only noticeable differences.

e. No general comparisons can be made between valley-floor sites and other topographic sites in the same region because the stations differed in altitude or distance from the divide.

f. An indication of the utility of separating an extensive mountain landscape into different regions for ecological study is revealed by the fact that there is no consistent relationship between topographically different stands on the East Slope as a whole. For example, in the tundra the ridgetop and north-facing stands have similar vegetation because wind and, conscquently, snow-cover features are apparently the major controlling factors, and these are similar in these two sites; the south-facing stand had less wind, more snow accumulation, and thus different vegetation. In the lower montane, on the other hand, the ridge-top and south-facing stands have similar environments and vegetation, while the north-facing stands differ from the ridgetop in environment and vegetation; in this region, wind is less different in the various sites, while temperature and soil moisture appear to be more controlling. 


\section{LITERATURE CITED}

Bates, Carlos G.

1924. Forest types in the central Rocky Mountains as affected by climate and soil. U.S.

D. A. Dept. Bull. 1233.

Baker, F. S.

1944. Mountain climates of the Western United States. Ecol. Monog. 14(2): 223-254.

Beadle, N. C. W.

1951. The misuse of climate as an indicator of vegetation and soils. Ecology 32(2): 343-345.

Beadle, N. C. W. and A. B. Costin

1952. Ecological elassification and nomenclature. Proc. Linnean Soc. of New South Wales, LXXVII (1-2): 61-82.

Billings, W. D.

1952. The environmental complex in relation to plant growth and distribution. Quart. Rev. Biol. $27(3)$ : 251-265.

Billings, W. D. and L. C. Bliss

1959. An alpine snowbank environment and its effects on vegetation, plant development and productivity. Ecology 40(3): 388-397.

Billings, W. D. and H. A. Mooney

1959. An apparent frost hummock-sorted polygon cycle in the alpine tundra of

Bliss, L. C. Wyoming. Ecology 40(1): 16-19.

1956. A comparison of plant development in microenvironments of arctic and al-

Braun-Blanquet, $\mathbf{J}$.

1932. Plant Sociology (transl. by H. S. Conard and G. D. Fuller) McGraw-Hill, New York. 439 pp.

1948-1949. Ubersicht der pflanzengesellschaften rätiens. Vegetatio $1: 29-41,129-146$, $285-316 ; 2: 20-37,214-237,341-360$.

Braun -Blanquet, J. and $H$. Jenny

1926. Vegetationsentwicklung und Bodenbildung in der alpinen Stufe der Zentralalpen. Neue Denkschr. Schweiz. Naturf. Ges. 63: 175-349.

Cain, Stanley $A$. 1944. Foundations of Plant Geography. Harper \& Brothers. XIV + 556 pp.

Cary, M.

1911. A biological survey of Colorado. U.S.D.A. North Amer. Fauna 33.

Churchill, E. D., and H. C. Hanson

1958. The concept of climax in arctic and alpine vegetation. Bot. Rev. 24: 127-191.

Clements, F. E.

1910. The life history of lodgepole burn forests. U.S.D.A. For. Serv. Bull. 79.

Clements, F. E. and Glen W. Goldsmith

1924. The phytometer method in ecology. The plant and community as instruments. Carnegie Inst. of Washington, Washington, D. C. 
Cook, A. W., and A. G. Topil

1952. Some examples of chinooks east of the mountains in Colorado. Bull. Amer. Meteor. Soc. 33: 42-47.

Cooper, Charles F.

1960. Changes in vegetation, structure, and growth of southwestern pine forests since white settlement. Ecol. Monog. 30: 129-164.

\section{Cooper, W. S.}

1908. Alpine vegetation in the vicinity of Long's Peak, Colorado. Bot. Gaz. 45: 319-337.

1926. The fundamentals of vegational change. Ecology VII(4): 391-413.

Costin, A. B.

1954. A study of the ecosystems of the Monaro region of New South Wales. Government Printer, Sydney.

Cowles, H. C.

1901. The physiographic ecology of Chicago and vicinity. Bot. Gaz. 31:73-108, 145181.

Cox, Clare F.

1933. Alpine plant succession on James Peak, Colorado. Ecol. Monog. III(3) : 300-372.

Crandall, C. S.

1897. Natural reforestation on the mountains of northern Colorado. Garden and

Dahl, Eilif Forest. Vol. 506: 437, and Vol. 507: 446-447.

1956. Rondane-Mountain vegetation in South Norway and its relation to the environment. Skrifter Utgitt av Det Norske Videnskaps-Akademi i Oslo I. Mat.-Naturv. Klasse. No. 3.

Daubenmire, R. F.

1938. Merriam's life zones of North America. Quart. Rev. Biol. 13: 327-332.

1943. Vegetational zonation in the Rocky Mountains. Bot. Rev, 9: 325-393.

1952. Forest vegetation of northern Idaho and adjacent Washington, and its bearing on concepts of vegetation classification. Ecol, Monog. 22(4): 301-330.

Douglass, Margaret Mattoon

1954. Ecology of forest succession on a ridge in the subalpine forest of northern Colorado. M.A. Thesis, University of Colorado, Boulder, Colorado.

Evans, Francis C.

1956. Ecosystem as the basic unit in ecology. Science 123: 1127-1128.

Greely, Gen. A. W.

1891. Report on the climatology of the arid regions of the U.S. with reference to irrigation. Exec. Doc. No. 287. Irrigation \& water storage in the arid regions. Executive documents of the House of Representatives for the 2nd session of the 51st Congress 1890-1891. Vol. 38.

Gjaerevoll, $\mathbf{O}$.

1956. The plant communities of the Scandinavian alpine snow-beds. $\bar{K}$. Norske Videnskabers Selskabs Skrifter (1). Bruns Bokhandel, Trondheim, 405 pp.

Gregg, Robert E.

1947. Altitudinal indicators among Formicidae. Univ. of Colo. Studies. Ser. D 2: 385-403.

Griggs, Robert F.

1956. Competition and succession on a Rocky Mountain fellfield. Ecology 37 : 8-20. 


\section{Harrington, H. D.}

1954. Manual of the plants of Colorado. Sage Books. Denver, Colorado. 666 pp.

\section{Hess, Dexter}

1959. Ecological studies of the growth of ponderosa pine on the East slope of the Rocky Mountain Front Range in Boulder County, Colorado. Ph.D. Thesis, Univeraity of Colorado, Boulder, Colorado.

Holch, A. E. et al.

1941. Root habits of certain plants of the foothills and alpine belta of the Rocky Mountain National Park. Ecol. Monog. 11(2) : 327-345.

\section{Ives, Ronald L.}

1938. Weather phenomena of the Colorado Rockies. Jour. Franklin Institute 226(6): 691-755.

Ives, Ronald L.

1941. Forest replacement rates in the Colorado headwater area. Bull. Torr. Bot. Club 61(6): 407-408.

Ives, Ronald L.

1950. Frequency and physical effects of chinook winds in the Colorado high plains region. Annals of Assoc. of Amer. Geographers XL(4) : 293-327.

\section{Johnson, Albert W.}

1956. Ecology of subalpine forest communities in the Silver Lake Valley of the Front Range in Colorado. Ph.D. Thesis. University of Colorado, Boulder, Colorado.

Johnson, W. M.

1945. Natural revegetation of abandoned crop land in the ponderosa pine zone of the Pike's Peak Region in Colorado. Ecology 26(4) : 363-374.

\section{Kiener, Walter}

1939. Sociological studies of the alpine vegetation on Long's Peak. Ph.D. Thesis. University of Nebraska.

Knorr, Owen A.

1959. The Birds of El Paso County, Colorado. Univ. Colo. Studies. Series in Biology. No. $5.48 \mathrm{pp}$.

Luti, Ricardo

1953. Ecological features of the vegetation of a ridge in the montane forest of Boulder

Ludi, $\mathbf{W}$. County, Colorado. M.S. Thesis. University of Colorado, Boulder, Colorado.

\section{Major, J.}

1921. Die pflanzengesellschaften des lauterbrunnentales und ihre sukzession. Beitrage zur geobotanische Landesaufnahme 9 . Verlag von Rascher und Cie., Zurich.

1951. A functional factorial approach to plant ecology. Ecology 32: 392-412.

Marr, John W.

1956. Vegetation and environment on the East Slope of the Front Range in Colorado. (mimeographed) Report to Quartermaster Research and Development Command, U. S. Army, Natick, Massachusetts.

Martinelli, M., Jr.

1959. Some hydrologic aspects of alpine snowfields under summer conditions. Jour. of Geophysical Research 64(4): 451.

Merriam, C. H.

1898. Life zones and crop zones of the United States. U.S.D.A., Div. Biol. Surv., Bull. 10. $79 \mathrm{pp}$. 
Niedrach, Robert J. and Robert B. Rockwell

1939. The Birds of Denver and Mountain Parks, Colo. Denver Mus. of Nat. Hist. Pop. Ser. No. 5.

Odum, Howard F. and Eugene P. Odum

1955. Trophic structure and productivity of a windward coral reef community on Eniwetok Atoll. Ecol. Monog. 25(3): 291-320.

Odum, Eugene P.

1957. The ecosystem approach in the teaching of ecology illustrated with sample class data. Ecology $38(3)$ : 531-535.

Oosting, Henry $J$.

1956. The study of plant communities. Second edition. W. H. Freeman and Co., San Francisco. $440 \mathrm{pp}$.

Osburn, William S.

1958. Ecology of winter snow-free areas of the alpine tundra of Nivot Ridge, Boulder County, Colorado. Ph.D. Thesis. University of Colorado, Boulder, Colorado.

Platt, Robert B.

1954. Autenvironment and plant ecology -- an assessment. VIII Congrès International de Botanique. pp. 225-227.

1958. The ultimate subdivisions of the environment and speties adjustment. Bull. Georgia Acad. Sci. XVI: 84-91.

Ramaley, Francis

1907. Plant zones in the Rocky Mountains of Colorado. Science. N. S. 26(671) : 642643.

1910. Remarks on some northern Colorado plant communities with special refer. ence to Boulder Park (Tolland, Colorado). Univ. of Colo. Stud. VII(4) : 223-236.

1915. Relative importance of different species in a mountain grassland. Bot. Gaz. 60(2): 154-157.

1916. Dry grassland of a high mountain park in northern Colorado. Plant World $19(9): 249-270$.

1916a. Quadrat studies in a mountain grassland. Bot. Gaz. 62(1): 70-74.

1919. Role of sodges in some Colorado plant communities. Am. Jour. of Bot. 6: 120130 .

1919a. Xerophytic grasslands at different altitudes in Colorado. Bull. Torr. Bot. Club. 46: 37-52.

1920. Subalpine lake-shore vegetation in north-central Colorado. Am. Jour, of Bot. $7:$ 57-74.

1927. Colorado plant life. University of Colorado Semicentennial Series 1877-1927, Vol. II. pp. viii +299 .

Ramaley, Francis, Gideon S. Dodds, and W. W. Robbins

1908. Studies in mesa and foothill vegetation. Univ. of Colo. Studies. VI(1): 11-51.

Ramaley, Francis and W. W. Robbins

1909. Studies in lake and stream-side vegetation. Univ. of Colo. Studies. VI(2): 133-168.

Retzer, John $L$.

1948. Soil developed from basalt in W. Colorado - Grand Mesa. Soil Science 66(5): 365-375.

1956. Alpine soils of the Rocky Mountains. Jour. Soil Sci, 7(1): 22-32. 
Robbins, W. W.

1910. Climatology and vegetation in Colorado. Bot. Gaz. 49: 256-280.

1917. Native vegetation and climate of Colorado in their relation to agriculture. Colo. Agric. Exper. Sta. Bull. 224: 1-56.

1918. Successions of vegetation in Boulder Park, Colorado. Bot. Gaz. LXV(6): 493525.

Rummell, Robert S.

1951. Some effects of livestock grazing on ponderosa pine forest and range in Central Washington. Ecology 32(4): 594-607.

Rydberg, P. A.

1916. Vegetative life zones of the Rocky Mountain Region. N. Y. Bot. Gard. Mem. 6: 477-499.

Schneider, E. C.

1909. The distribution of woody plants in the Pike's Peak Region. Colo. College Publ. Gen. Ser. No. 39 Sci. Ser. XII(6): 137-170.

1911. The succession of plant life on the gravel slides in the vicinity of Pike's Peak. Colo. College Publ. Sci. Ser. XII(8): 289-311.

\section{Schramm, J. R.}

1958. The mechanism of frost heaving of tree seedlings. Proc. Amer. Phil. Soc.

Schroeter, C. 102(4): 333-350.

1926. Das Pfanzenleben der Alpen. Verlag von Albert Raustein, Zurich.

Sehwan, H. E. and D. F. Costello

1951. Rocky Mountain alpine type, range conditions, trends and land use: A Prelimin-

Sjors, Hugo ary Report. U. S. Dept. Agric. Forest Service. 1-17.

1955. Remarks on ecosystems. Svensk Botanisk Tidskrift Bd. 49, H. 1-2: 155-169.

Sperry, O. E.

1936. A study of the growth transpiration and distribution of the conifers of Rocky

\section{Stabelin, R.} Mountain National Park. Bull. Torr. Bot. Club 63: 75-103.

1943. Factors influencing the natural restocking of high altitude burns by coniferous trees in the Central Rocky Mountains. Ecology 24(1): 19-30.

Tansley, A. G.

1935. The use and abuse of vegetational concepts and terms. Ecology 16: 284-307.

U. S. Army

1874-90. Reports of the Chief Signal Officer in Congressional Serial Set Volumes. In 15 volumes from Vol. 1678 through Vol. 2720.

U. S. Weather Bureau

1933. Climatic summary of the United States, Sec. 22, Western Colorado. U. S. Govt. Printing Office.

Vestal, A. G.

1917. Foothills vegetation in the Colorado Front Range. Bot. Gaz. 64: 353-385.

Wahlstrom, Ernest E.

1947. Cenozoic physiographic history of the Front Range, Colorado. Geol. Soc. Amer. Bull. 58: 551-572. 
Washburn, A. C.

1956. Classification of patterned ground and review of suggested origins. Geol. Soc. Amer. Bull. 67: 823-866.

Watt, A. S.

1947. Pattern and process in the plant community. Jour. Ecol. 35: 1-22.

Weaver, J. E. and F. E. Clements 1938. Plant ecology. Second edition. McGraw-Hill, New York.

Weber, William A.

1961. Handbook of plants of the Colorado Front Range. Second edition. University of Colorado Press, Boulder, Colorado. $232 \mathrm{pp}$.

Whitfield, C. J.

1932. Ecological aspects of transpiration. I. Pike's Peak Region: Climatic aspects. Bot. Gaz. 93: 436-452.

1933. The ecology of the vegetation of the Pike's Peak Region. Ecol. Mono. 3: 75105.

Whittaker, R. H.

1953. A consideration of climax theory: the climax as a population and pattern. Ecol. Monog. 23: 41-78.

Young, Robert $T$.

1907. Forest formations in Boulder County, Colorado. Bot. Gaz. XLVI: 321-352. 


\section{APPENDIX I}

Complete List of Plant Species in All Stands (Names according to Weber, 1961)

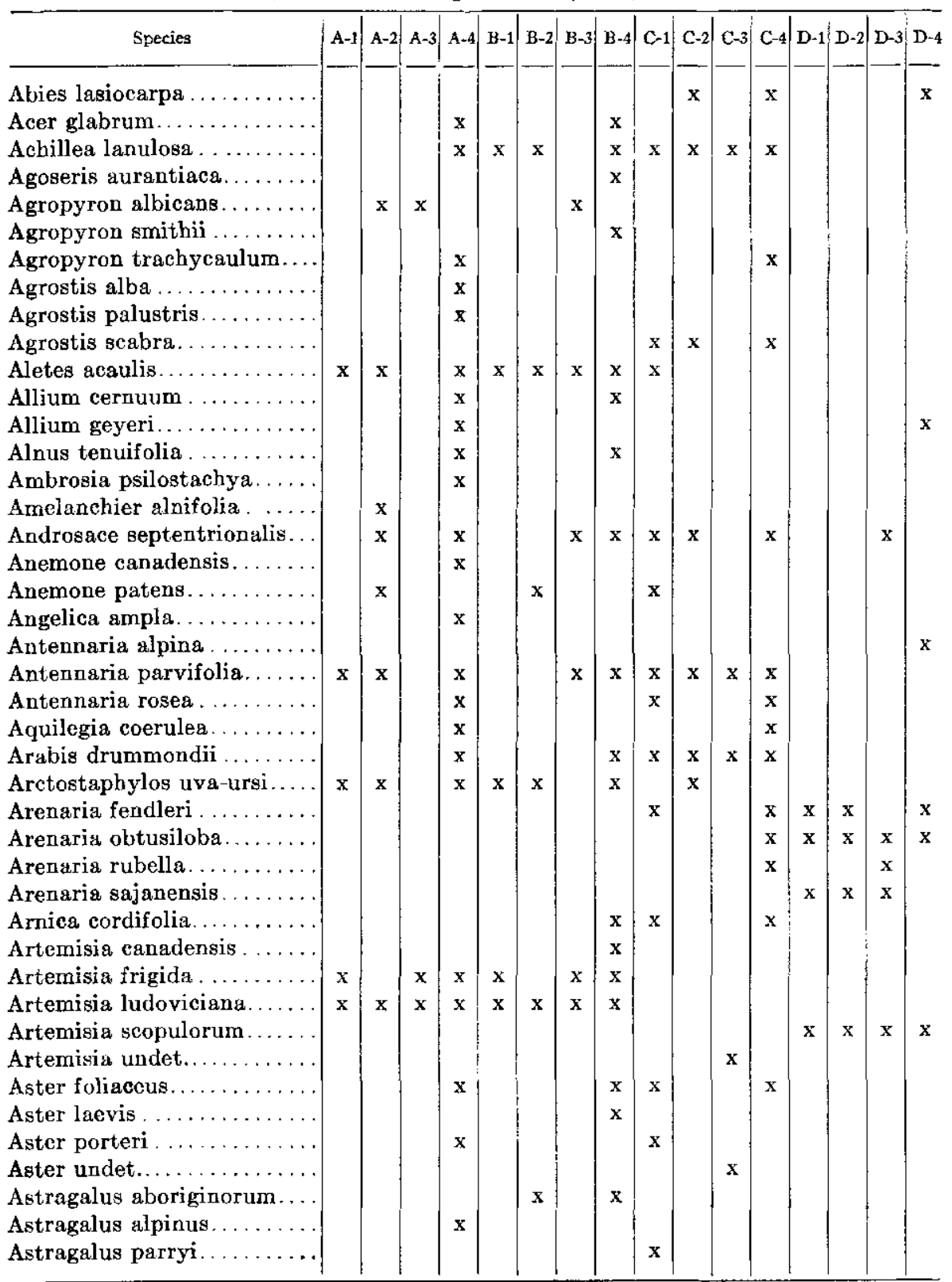


Plant Species List (Continued)

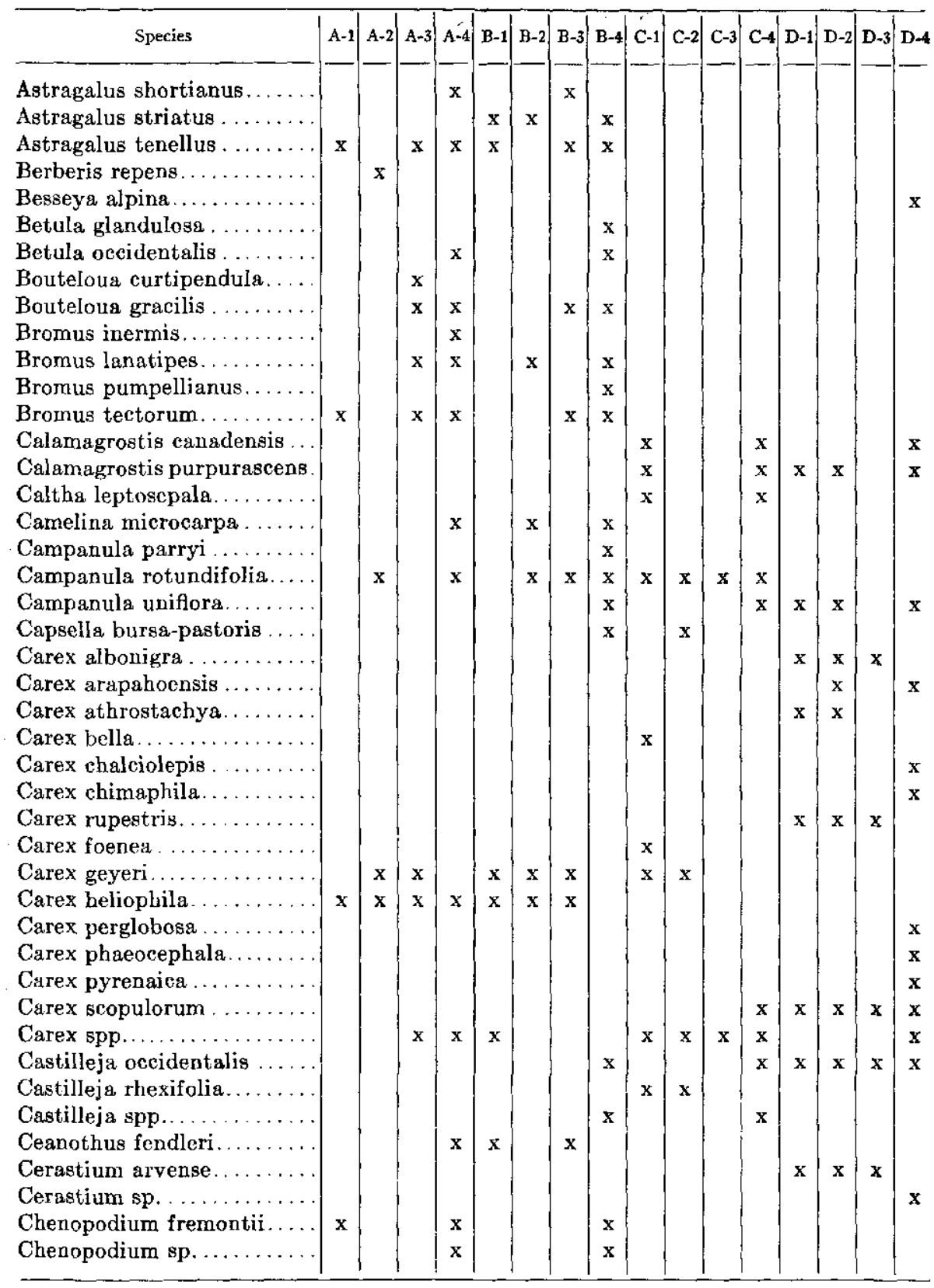


Plant Species List (Continued)




Plant Species List (Continued)

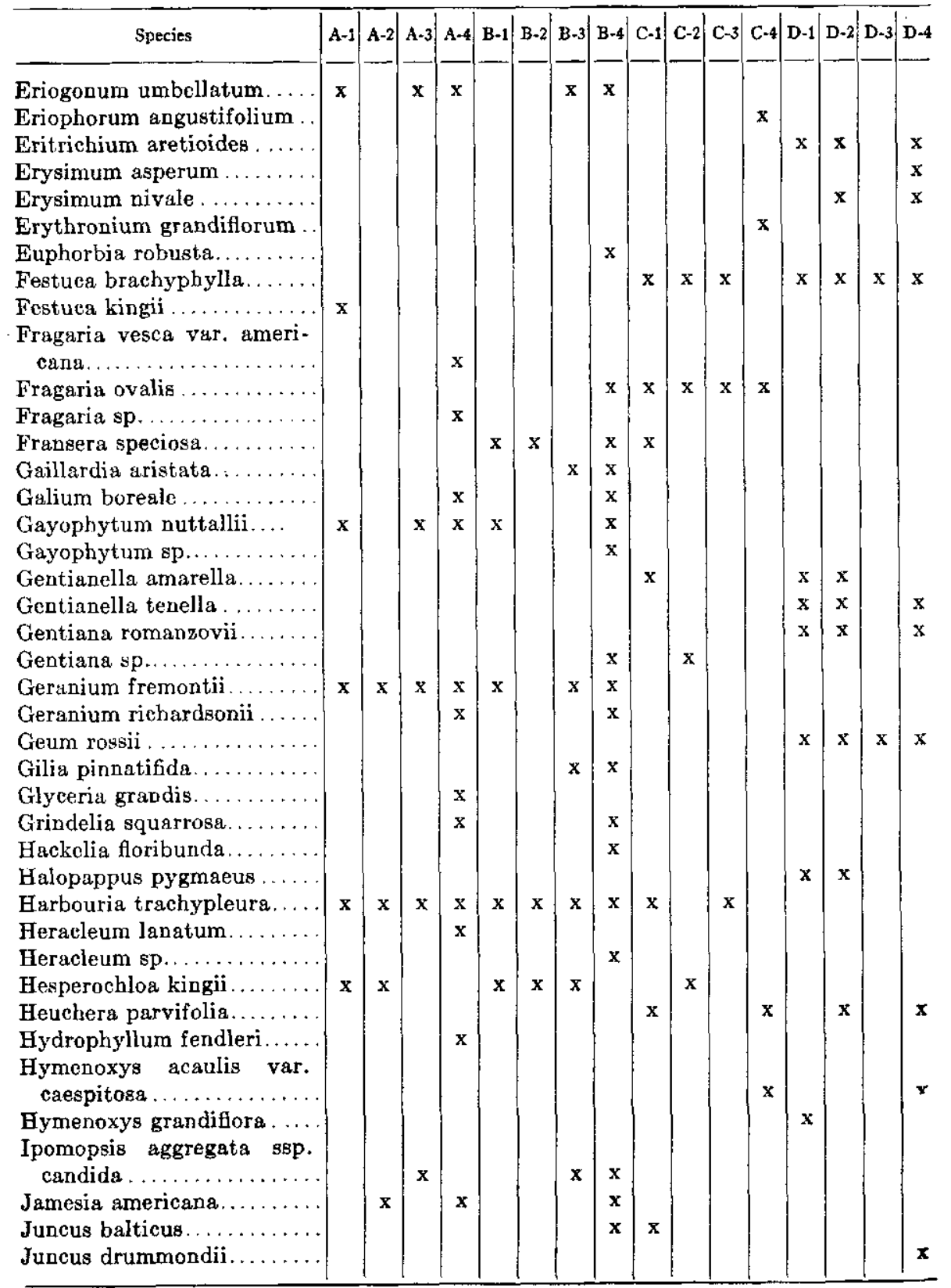


Plant Species List (Continued)

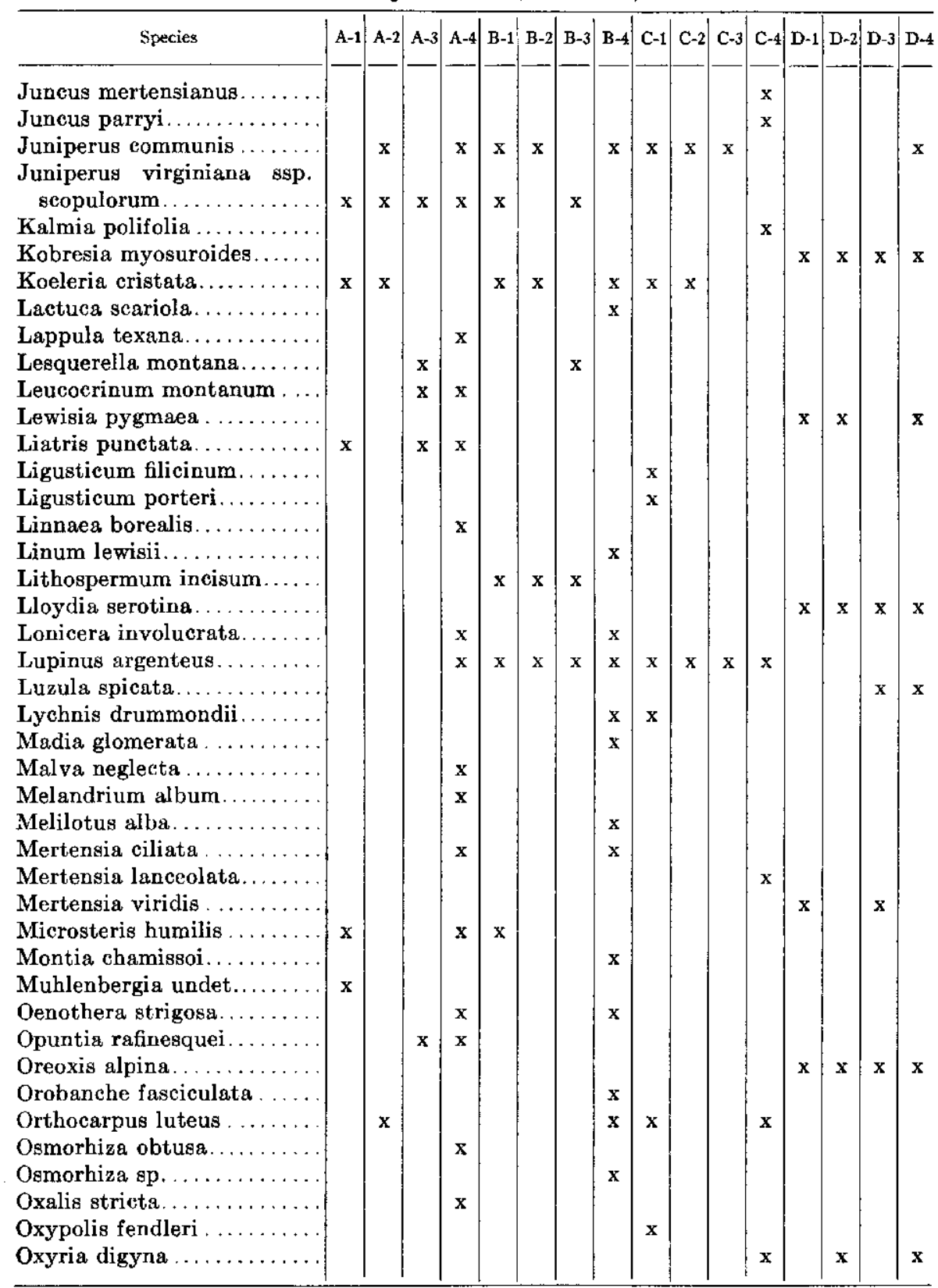




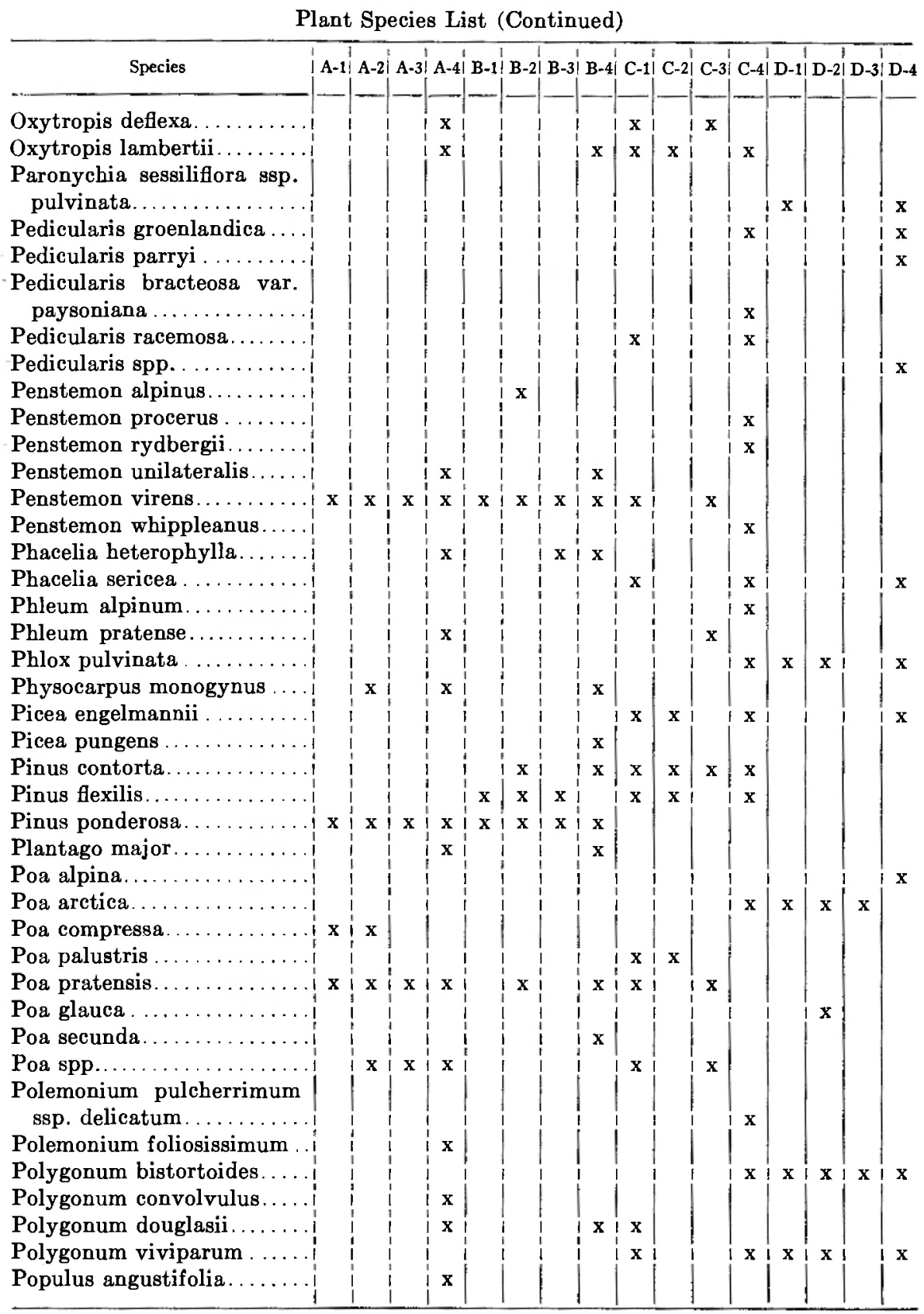


Plant Species List (Continued)

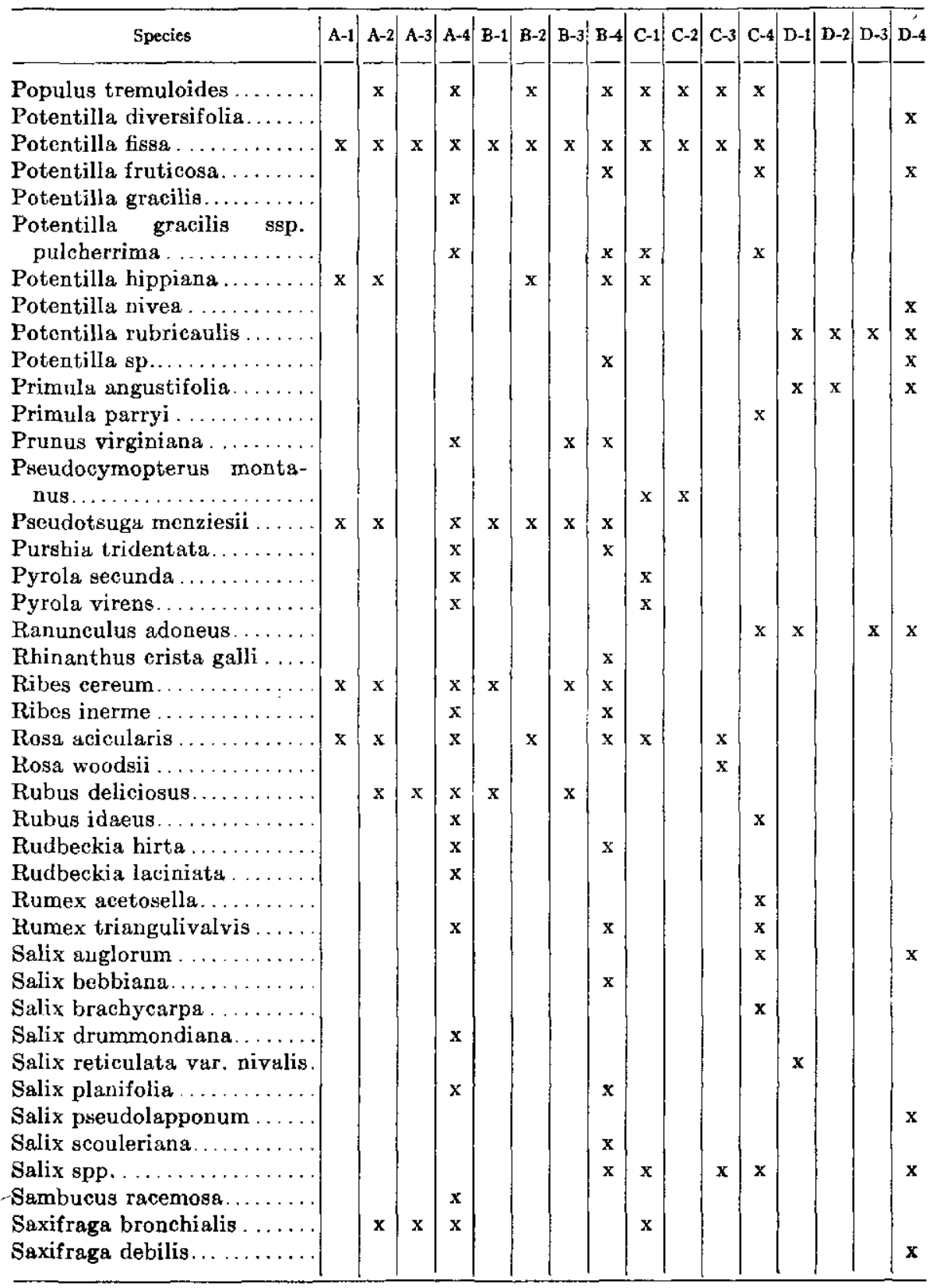


Plant Species List (Continued)

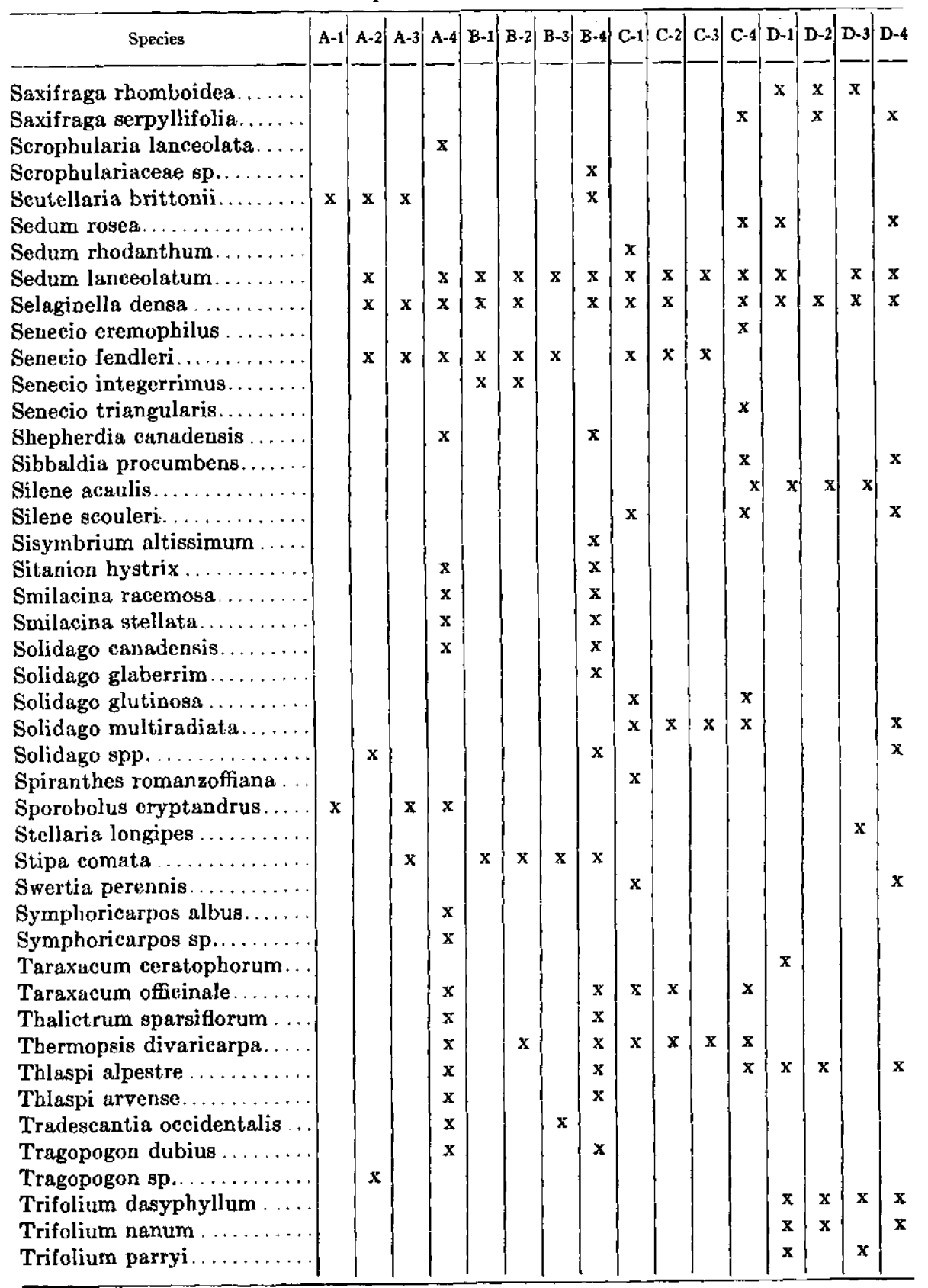




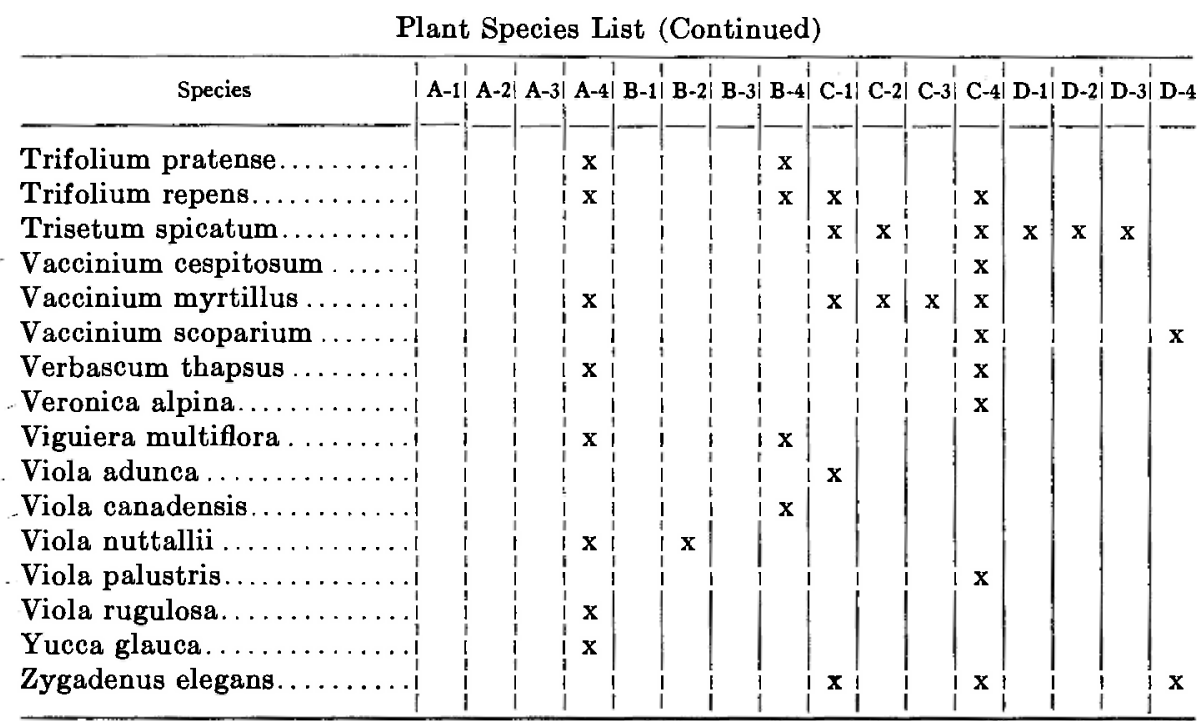


APPENDIX II

Summaries of Environment Data

TABLE A

University of Colorado - Institute of Arctic \& Alpine Research - Summary of Mountain Environments

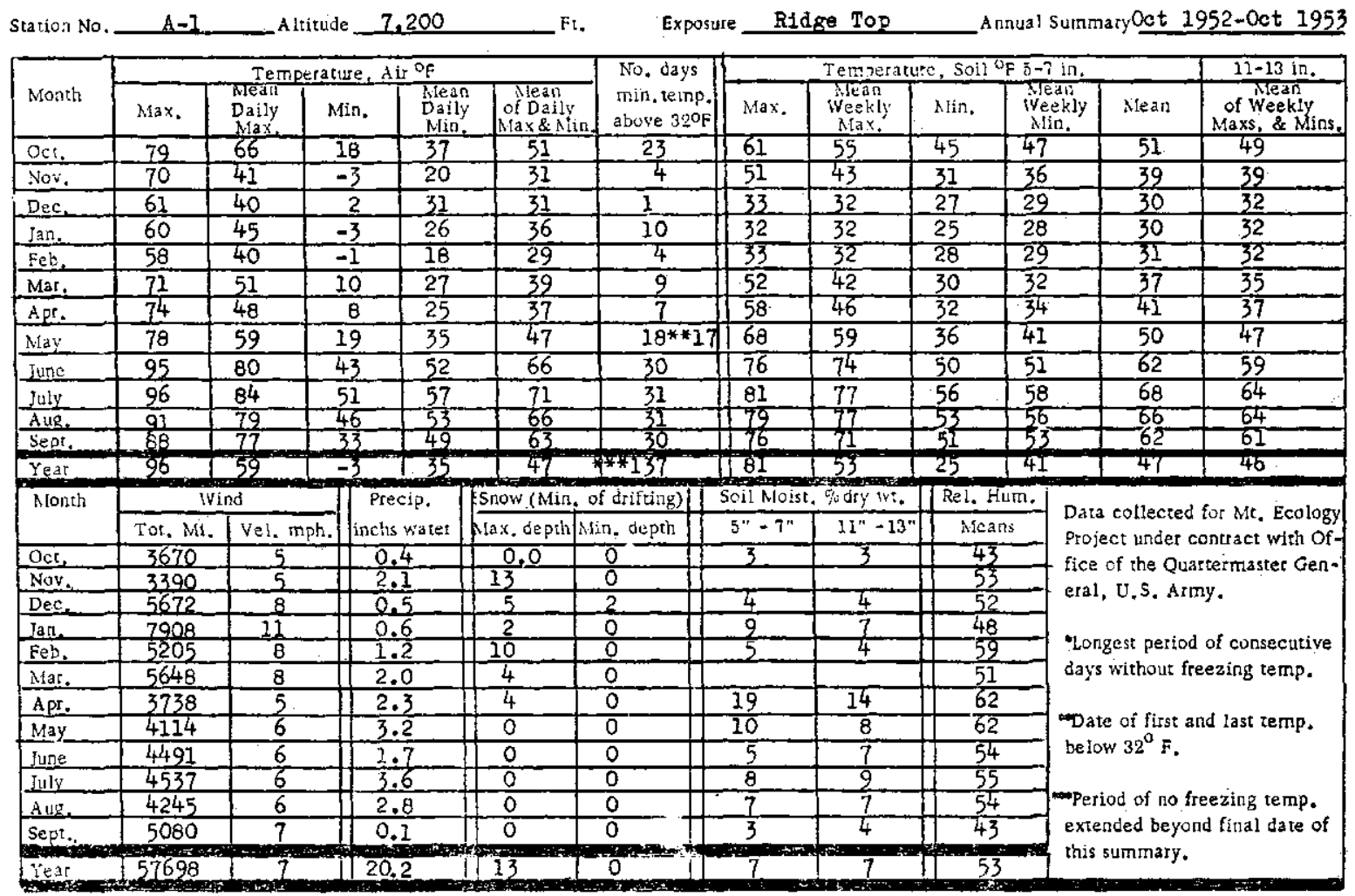


University of Colorado - Institute of Arctic \& Alpine Research - Summary of Mountain Environments

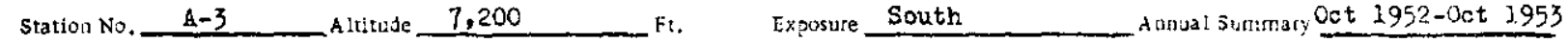

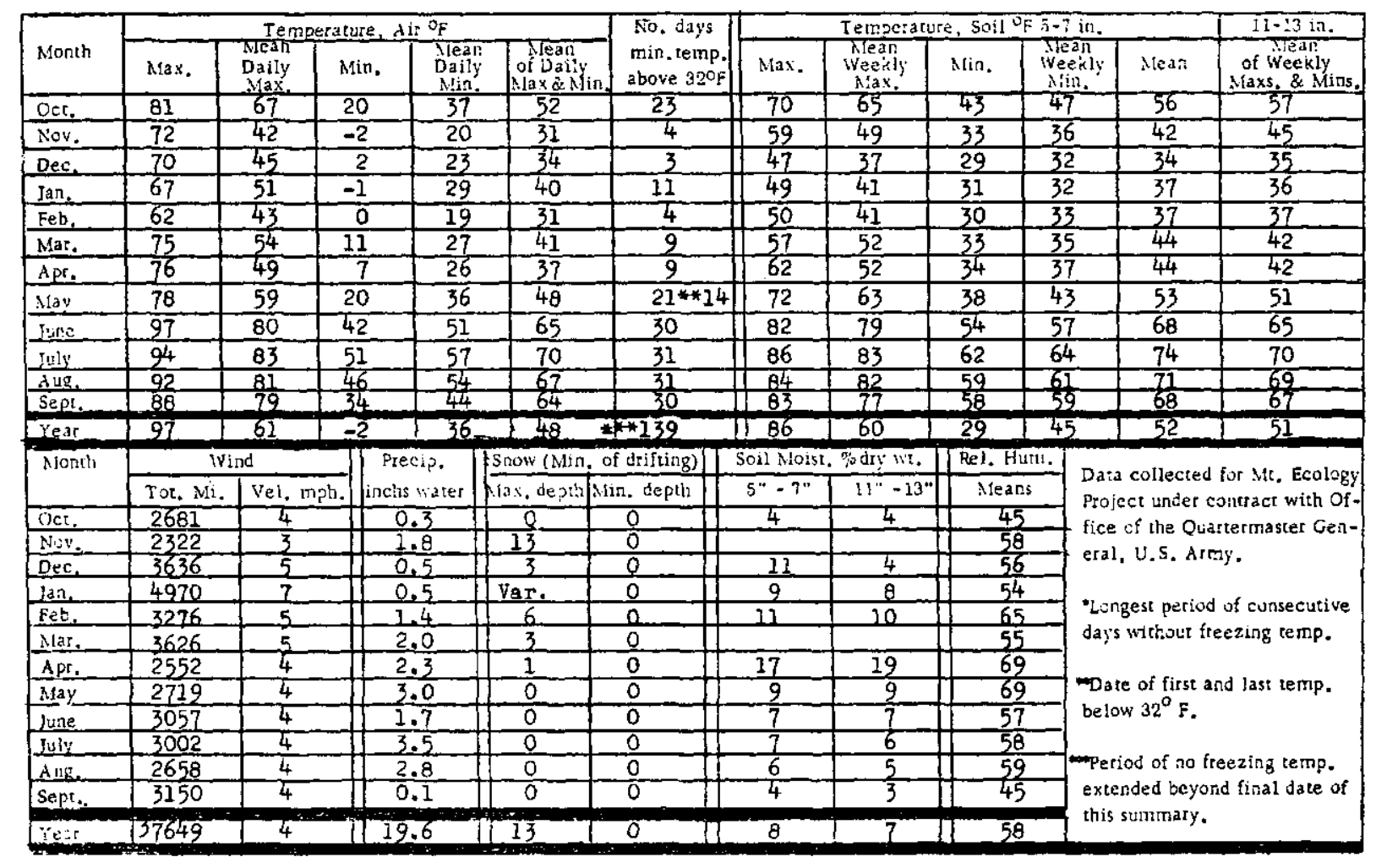


University of Colorado - Institute of Arctic \& Alpine Research - Summary of Mountain Environments

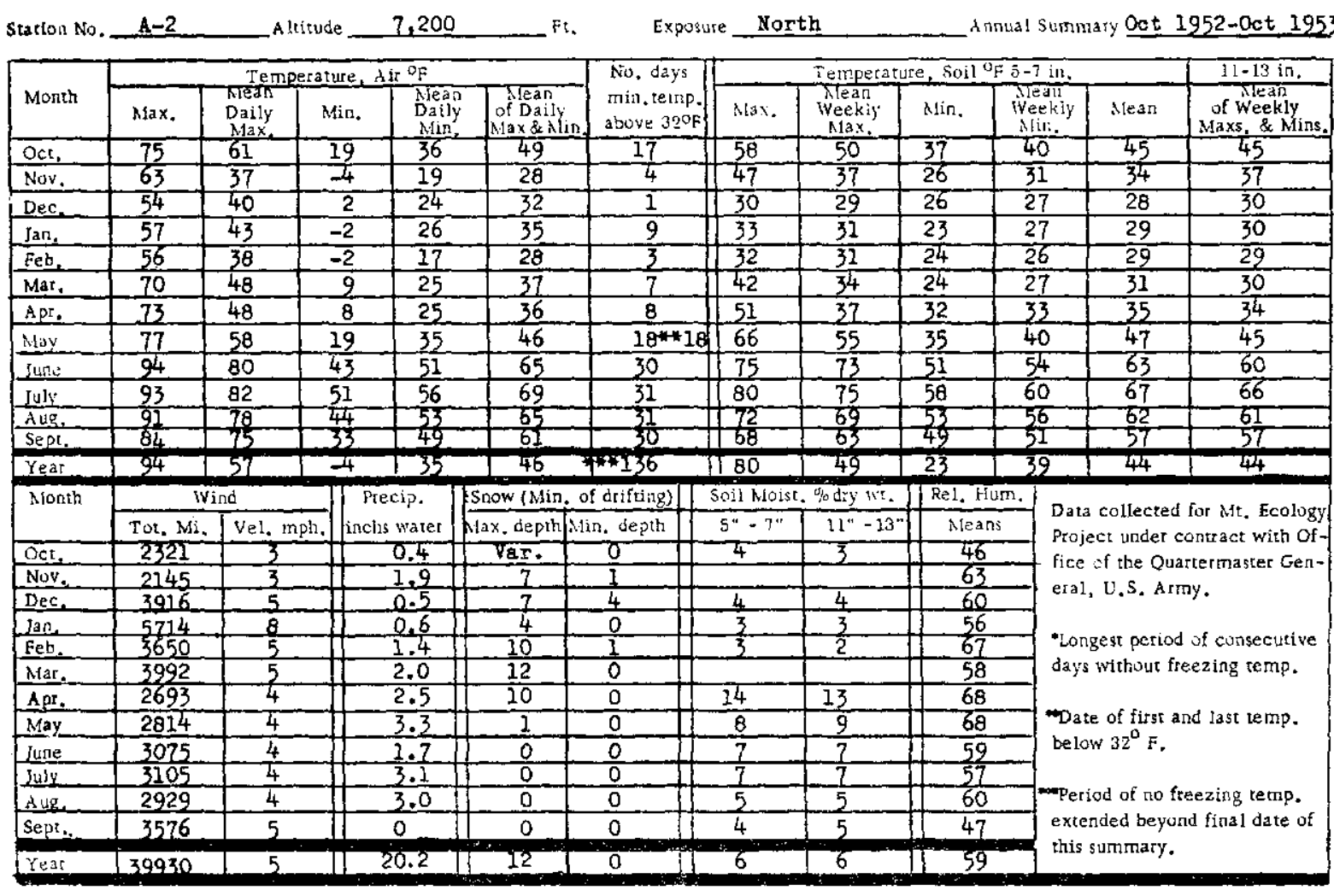


University of Colorado - Institute of Arctic \& Alpine Research - Summary of Mountain Environments Station No. A-4 Altitude $\quad 7,500$ Ft. Exposure Valley A nnual Summary Oot 2952-0et 195

\begin{tabular}{|c|c|c|c|c|c|c|c|c|c|c|c|c|c|}
\hline \multirow[b]{2}{*}{ Month } & \multicolumn{5}{|c|}{ Temperature, dir of } & \multirow{2}{*}{$\begin{array}{l}\text { No, days } \\
\text { min, temp. } \\
\text { above } 32^{\circ} \mathrm{F}\end{array}$} & \multicolumn{6}{|c|}{ Temperarure, Soil ${ }^{\circ} \mathrm{F} 5-7$ in, } & \multirow{2}{*}{\begin{tabular}{|c|}
$11-13$ in, \\
Nezn \\
of Weekly \\
Maxs. \& Mins. \\
\end{tabular}} \\
\hline & hax. & \begin{tabular}{l|l|} 
Meant \\
Dainy \\
Miax,
\end{tabular} & Min. & $\begin{array}{l}\text { Mean } \\
\text { Daily } \\
\text { Min. }\end{array}$ & 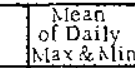 & & Max. & $\begin{array}{c}\text { Mean } \\
\text { Weekly } \\
\text { Max. }\end{array}$ & Nin. & \multicolumn{2}{|c|}{$\begin{array}{l}\text { Meanin } \\
\text { Weekly } \\
\text { Min. }\end{array}$} & Mean & \\
\hline Oct. & 73 & 61 & 2. & 24 & 43 & 2 & 60 & 53 & 38 & \multicolumn{2}{|c|}{41} & 47 & 47 \\
\hline Nov. & 64 & 38 & -13 & 10 & 24 & 0 & 49 & 38 & 20 & \multicolumn{2}{|l|}{29} & 33 & 37 \\
\hline Dec, & 57 & 39 & -12 & 14 & 27 & 0 & 32 & 27 & 22 & \multicolumn{2}{|l|}{24} & 25 & 29 \\
\hline Jan. & 58 & 44 & -1 & 23 & 34 & 7 & 32 & 30 & 23 & \multicolumn{2}{|c|}{25} & 28 & 31 \\
\hline Feb, & 54 & 36 & -18 & 10 & 23 & 1 & 37 & 33 & 24 & \multicolumn{2}{|c|}{28} & 31 & 32 \\
\hline Mar. & 67 & 46 & 7 & 21 & 34 & 1 & 53 & 44 & 27 & \multicolumn{2}{|c|}{31} & 38 & 37 \\
\hline Apr. & 69 & 46 & 0 & 19 & 33 & 2 & 52 & 43 & 32 & \multicolumn{2}{|l|}{34} & 38 & 38 \\
\hline May & 72 & 54 & 18 & 29 & 41 & 6 & 65 & 57 & 37 & \multicolumn{2}{|c|}{41} & 49 & 47 \\
\hline June & 87 & 71 & 28 & 38 & 55 & $27 * 5$ & 73 & 71 & 49 & \multicolumn{2}{|c|}{52} & 62 & 59 \\
\hline July & 84 & 74 & 39 & 44 & 59 & 31 & 71 & 74 & 56 & \multicolumn{2}{|l|}{58} & 66 & 63 \\
\hline Aug, & 81 & 71 & \multirow{2}{*}{$\frac{34}{27}$} & 40 & 56 & 3 & 73 & 70 & 53 & 56 & & 63 & 62 \\
\hline Sept. & 80 & 71 & & 34 & 52 & & 68 & 65 & 52 & 52 & & 59 & 57 \\
\hline Year & 87 & 54 & -18 & 25 & 40 & * 89 & 113 & 50 & 20 & 39 & & 45 & 45 \\
\hline Nionth & iv & & & cip. & S.row (Min. & of drifting) & Soil Moist, & tio dry wit. & Rel, Hur & & & & \\
\hline & Tor, Mi. & vel. miph & & water & Max, depth & Jin. depth & $5 "-7 "$ & $11^{n}-13^{n}$ & Means & & & under & Mit. Ecology \\
\hline Oct. & 1383 & 3 & & 0.4 & Yar. & Q & 3 & 2 & 62 & & & of the our & itermaster Gen- \\
\hline Nov. & 1762 & 8 & & 10 & 1 & 0 & & & 75 & & & U. $\mathrm{S}, \mathrm{AT}$ & \\
\hline Dec. & 3096 & 4 & & 0.6 & $\frac{6}{6}$ & 2 & 6 & 6 & 72 & & & & \\
\hline$\frac{\mathrm{Jan},}{\mathrm{Feb}}$ & $\frac{4792}{3233}$ & $\frac{6}{5}$ & & 0.6 & 8 & ? & $\frac{6}{6}$ & 2 & 64 & & & gest perioc & of consecutive \\
\hline$\frac{\text { Feb, }}{\text { Mar. }}$ & $\frac{3233}{3142}$ & $\frac{5}{4}$ & & 1.2 & 9 & 1 & 3 & 2 & 67 & & dons & without $\mathrm{fr}$ & eezing temp. \\
\hline$\frac{\text { Mats }}{\text { Apt, }}$ & $\frac{3142}{2262}$ & $\frac{4}{4}$ & & 2.0 & 8 & 0 & & & 65 & & & & \\
\hline May & 2101 & 3 & & $\frac{2.3}{3.5}$ & $\frac{3}{0}$ & $\frac{0}{0}$ & $\frac{8}{7}$ & $\frac{4}{6}$ & $\frac{72}{73}$ & & Dat & of first a & nd last temp. \\
\hline June & 1321 & 2 & & 1.6 & $\overline{0}$ & 0 & $\frac{1}{4}$ & $\frac{0}{4}$ & $\frac{16}{69}$ & & & $+32^{\circ} \mathrm{F}$. & \\
\hline $\mathrm{July}$ & 1326 & 2 & & 2.6 & 0 & 0 & 3 & 3 & 74 & & & & \\
\hline dug. & 1218 & 2 & & 3.2 & 0 & 0 & 6 & 6 & 71 & & & od of no $f_{1}$ & eezing temp. \\
\hline Sept. & 2043 & 3 & & 0.2 & 0 & 0 & 3 & 4 & 62 & & & ded beyor & id final date of \\
\hline
\end{tabular}


University of Colorado - Institute of Arctic \& Alpine Research - Summary of Mountain Environments Station No. BAltitude 8,500 $\mathrm{Fi}$. Exposure Ridge Top Annuai Summary Oct 1952-0ct 1953

\begin{tabular}{|c|c|c|c|c|c|c|c|c|c|c|c|c|c|}
\hline \multirow[b]{2}{*}{ Month } & \multicolumn{5}{|c|}{ Temperature, dif of } & \multirow{2}{*}{$\begin{array}{l}\text { No. days } \\
\text { min. temp. } \\
\text { above } 32^{\circ} \mathrm{F}\end{array}$} & \multicolumn{6}{|c|}{ Temperature, Soil ${ }^{\circ} \mathrm{F}-7$ in, } & \multirow{2}{*}{$\begin{array}{c}\text { 11-13 in. } \\
\text { Mean } \\
\text { Weekly } \\
\text { Maxs. \& Mins. }\end{array}$} \\
\hline & Max. & $\begin{array}{l}\text { Rleat } \\
\text { Daily } \\
\text { Max }\end{array}$ & Min. & $\begin{array}{l}\text { Niean } \\
\text { Daily } \\
\text { Min. }\end{array}$ & $\begin{array}{c}\text { Mean } \\
\text { of Daily } \\
\text { Max \& Nin }\end{array}$ & & Max. & $\begin{array}{c}\text { Mean } \\
\text { Weekly } \\
\text { Max. }\end{array}$ & Ain. & \multicolumn{2}{|c|}{$\begin{array}{l}\text { Mean } \\
\text { Weekly } \\
\text { Min. }\end{array}$} & Nean & \\
\hline Oct. & 75 & 61 & 17 & 34 & 47 & 19 & 57 & 51 & 40 & 42 & & 46 & 47 \\
\hline Noy. & 63 & 37 & -7 & 16 & 27 & 3 & 47 & 38 & 27 & 33 & & 36 & 37 \\
\hline Dec, & 62 & 36 & -4 & 18 & 27 & 1 & 35 & 30 & 26 & 27 & & 29 & 30 \\
\hline Jan. & 58 & 41 & -4 & 21 & 31 & 5 & 31 & 29 & 24 & 26 & & 28 & 29 \\
\hline Feb & 54 & 35 & -6 & 13 & 24 & 0 & 31 & 29 & 22 & 24 & & 27 & 29 \\
\hline Mar. & 67 & 45 & 3 & 21 & 33 & 1 & 44 & 35 & 24 & 29 & & 32 & 32 \\
\hline Apr. & 71 & 43 & 3 & 20 & 32 & 5 & 47 & 36 & 32 & 32 & & 34 & 35 \\
\hline May & 74 & 53 & 12 & 28 & 41 & $12 * * 26$ & 57 & 49 & 34 & 38 & & 43 & 43 \\
\hline June & 89 & 74 & 37 & 47 & 61 & 30 & 68 & 65 & 48 & 52 & & 58 & 57 \\
\hline July & 87 & 77 & 47 & 53 & 65 & 31 & 72 & 69 & 56 & 58 & & 63 & 62 \\
\hline Aug, & 85 & 73 & 41 & 48 & 61 & 31 & 70 & 68 & 52 & 55 & & 61 & 60 \\
\hline \multicolumn{14}{|l|}{$\frac{\text { Aust }}{\text { Sept. }}$} \\
\hline \multicolumn{14}{|l|}{ Year } \\
\hline \multirow[t]{2}{*}{ Month } & \multicolumn{2}{|c|}{ Wind } & \multirow{2}{*}{\multicolumn{2}{|c|}{$\begin{array}{c}\text { Precip. } \\
\text { inchs water }\end{array}$}} & \multicolumn{2}{|c|}{ Snow (Min, of driftiag) } & \multicolumn{2}{|c|}{ Soil Mloist, $\%$ dry wt. } & \multicolumn{2}{|c|}{ Rel. Hum. } & \multirow{4}{*}{\multicolumn{3}{|c|}{$\begin{array}{l}\text { Data collected for Mi, Ecology } \\
\text { Project under contract with Of- } \\
\text { fice of the Quartermaster Gen- } \\
\text { eral }\end{array}$}} \\
\hline & Tor, Mi. & Vel. mph & & & Iax. deptha & Nin, depth & $5 n-7 n$ & $11^{\prime \prime}-13^{\prime \prime}$ & Alears & & & & \\
\hline Ocr. & 3140 & 4 & & 0.4 & 0 & $\sigma$ & 3 & 3 & \multicolumn{2}{|l|}{$\frac{\text { Near.s }}{46}$} & & & \\
\hline Nov, & 3278 & 5 & & 2.0 & 10 & 1 & & & 58 & & & & \\
\hline Dec & $69+6$ & 10 & & 0.7 & पar. & Yas. & 4 & 4 & 59 & & & & \\
\hline Ian. & 20200 & 14 & & 0.6 & Var. & Var. & 4 & 3 & 67 & & & & \\
\hline Feb. & 6163 & 9 & & 1.7 & Var. & Var, & 4 & 4 & 73 & & & gest perio & of consecutive \\
\hline Mlar. & 6607. & 9 & & 2.2 & 11 & 0 & & & 63 & & days & without $f$ & ezing temp. \\
\hline Apr. & 4974 & 7 & & 2.7 & 8 & 0 & 14 & $\overline{9}$ & 67 & & & & \\
\hline May & 4398 & 6 & & 3.6 & 0 & 0 & 12 & 13 & 69 & & & of first & dast temp. \\
\hline June & 3907 & 5 & & 1.6 & 0 & 0 & 30 & 10 & 61 & & & & \\
\hline Iuly & 3788 & 5 & & 2.9 & 0 & 0 & 10 & 10 & 52 & & & & \\
\hline Aug. & 3,60 & 5 & & 2.9 & $\overline{0}$ & 0 & 8 & 7 & 55 & & & od of no & eezing temp. \\
\hline Sept. & 4829 & 6 & & 0.1 & 0 & ) & 4 & $\frac{1}{4}$ & 47 & & & nded beyo & d final date of \\
\hline
\end{tabular}


University of Colorado - Institute of Arctic \& Alpine Research - Summary of Mountain Environments Station No. B-3 A ltitude 8,500 Ft. Annual Summaryoct 2952-0ct 2953

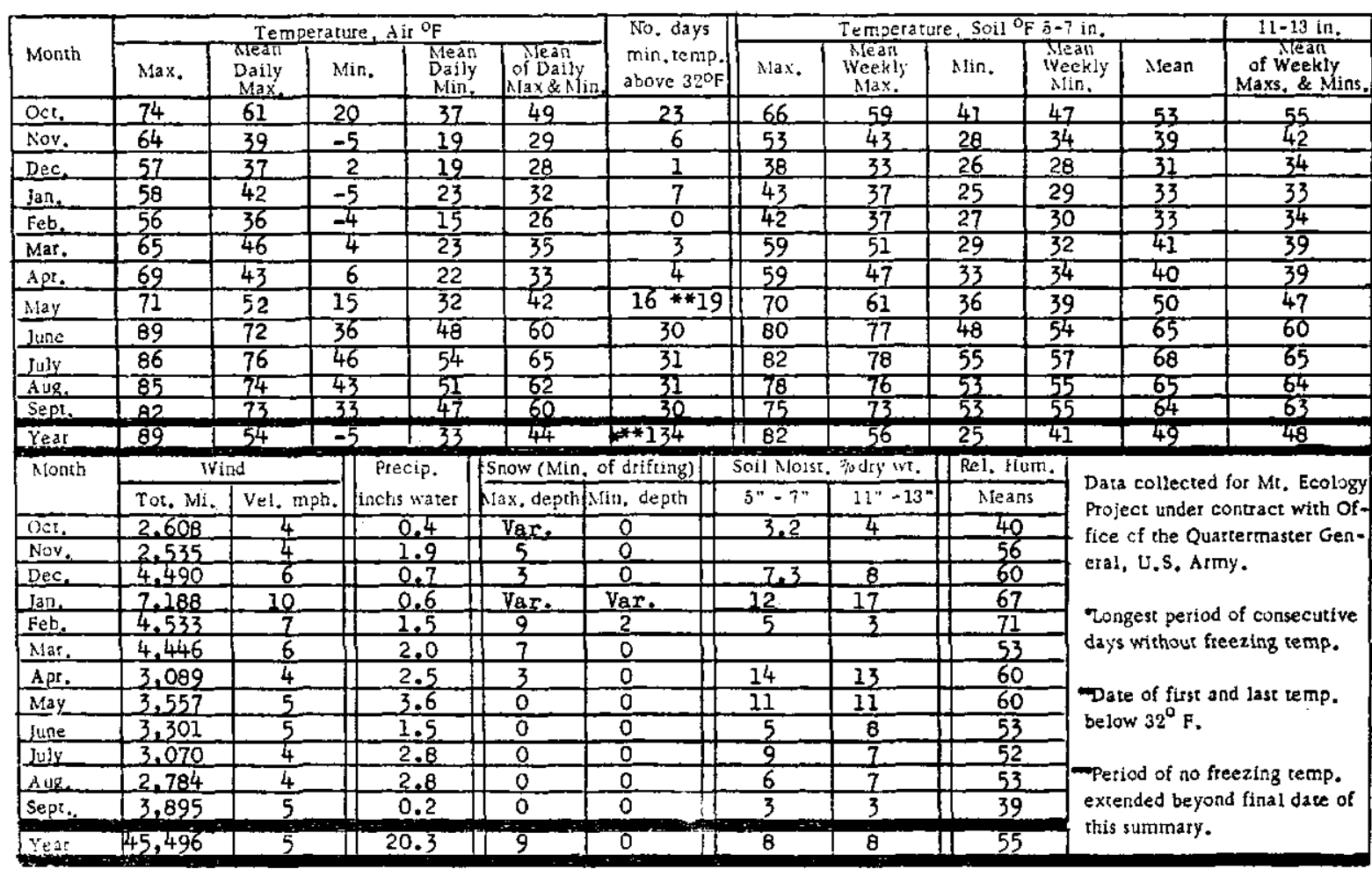


TABLE G

University of Colorado - Institute of Arctic \& Alpine Research - Summary of Mountain Environments Scation No. $=\mathrm{B}=2$ Altitude $\quad 0,500$ Ft. Exposure _. North Annual Summary Oct 1952-Oct 1953

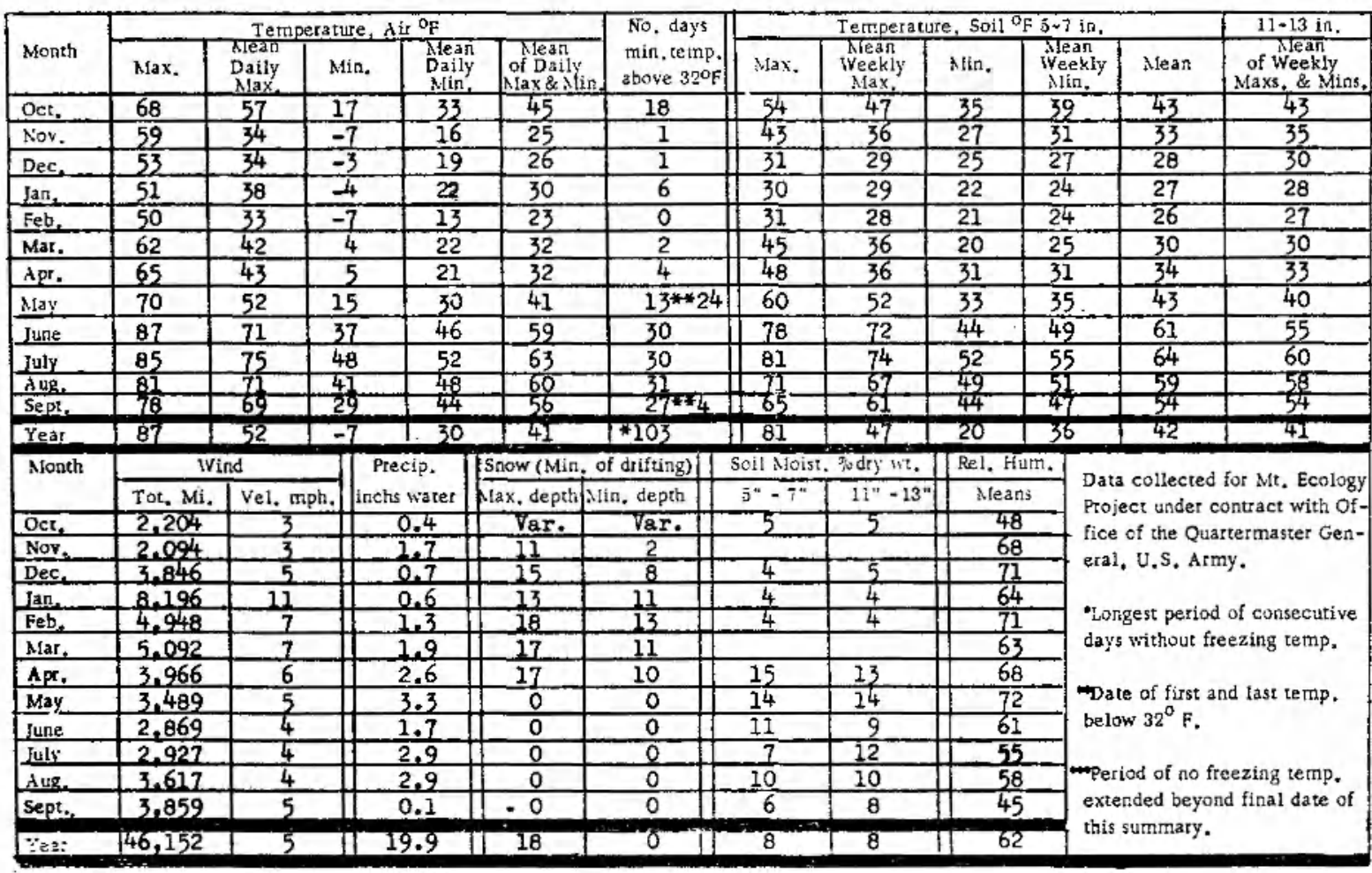


University of Colorado - Institute of Arctic \& Alpine Research - Summary of Mountain Environments

\begin{tabular}{|c|c|c|c|c|c|c|c|c|c|c|c|c|c|}
\hline \multirow[b]{2}{*}{ Month } & \multicolumn{5}{|c|}{ Temperature, dir ${ }^{\circ} \mathrm{F}$} & No. days & \multicolumn{6}{|c|}{ Temperature, soil ${ }^{\circ} \mathrm{F} 5-\mathrm{T}$ in. } & \multirow{2}{*}{\begin{tabular}{|c|}
$11-13$ in. \\
of Weekily \\
Maxs, \& Mins.
\end{tabular}} \\
\hline & Max. & $\begin{array}{l}\text { Mean } \\
\text { Daily } \\
\text { Max }\end{array}$ & Min. & $\begin{array}{l}\text { Mean } \\
\text { Daily } \\
\text { Mlin }\end{array}$ & $\begin{array}{l}\text { Mean } \\
\text { of Daily } \\
\text { Miax \& Ali }\end{array}$ & $\begin{array}{l}\text { mir. temp. } \\
\text { above } 32^{\circ} \mathrm{F}\end{array}$ & Max. & $\begin{array}{l}\text { Mean } \\
\text { Weaty } \\
\text { Max. }\end{array}$ & $\operatorname{Min}$. & \multicolumn{2}{|c|}{$\begin{array}{l}\text { Mean } \\
\text { Weekly } \\
\text { Min. }\end{array}$} & Mean & \\
\hline Oct. & 71 & 60 & 5 & 25 & 42 & 4 & 61 & 55 & 37 & \multicolumn{2}{|c|}{40} & 48 & 49 \\
\hline Nor. & 61 & 37 & -14 & 12 & 24 & 2 & 51 & 41 & 22 & \multicolumn{2}{|l|}{30} & 36 & 38 \\
\hline Dec. & 55 & 35 & -20 & 13 & 24 & $\overline{0}$ & 31 & 29 & 18 & \multicolumn{2}{|l|}{22} & 26 & 26 \\
\hline Јал. & 56 & 39 & -5 & 22 & 31 & 4 & 38 & 33 & 23 & \multicolumn{2}{|l|}{25} & 29 & 30 \\
\hline Feb. & 48 & 33 & -18 & 9 & 21 & I & 41 & 34 & 22 & \multirow{2}{*}{\multicolumn{2}{|c|}{$\frac{27}{30}$}} & 30 & 31 \\
\hline Mar. & 61 & 42 & 5 & 18 & 30 & 0 & 52 & 45 & 25 & & & 38 & 36 \\
\hline Apr. & 65 & 42 & -8 & 18 & 30 & 0 & 54 & 42 & 32 & \multicolumn{2}{|c|}{$\frac{30}{33}$} & 37 & 37 \\
\hline May & 68 & 51 & 14 & 28 & 39 & 7 & 65 & 56 & 34 & \multicolumn{2}{|l|}{38} & 47 & 45 \\
\hline June. & 84 & 71 & 32 & 40 & 55 & $29 * * 4$ & 74 & 70 & 47 & \multicolumn{2}{|l|}{51} & 60 & $57^{-}$ \\
\hline July: & 82 & 73 & 37 & 44 & 59 & 31 & 74 & 70 & 55 & \multicolumn{2}{|c|}{57} & 64 & 62 \\
\hline$\frac{1}{A y 2 .}$ & 80 & 71 & 32 & 40 & 56 & $30 * 19$ & 73 & $I$ & 52 & \multirow{2}{*}{\multicolumn{2}{|c|}{$\frac{55}{51}$}} & 63 & $6 I$ \\
\hline Sept. & 76 & 68 & 22 & 33 & 50 & 15 & 66 & 64 & 51 & & & 58 & 57 \\
\hline Year & $\therefore$ & 52 & & & & 45 & 74 & 51 & 18 & \multicolumn{2}{|c|}{$\frac{51}{38}$} & 45 & 44 \\
\hline \multirow[t]{2}{*}{ Month } & \multicolumn{2}{|c|}{ Wind } & \multirow{2}{*}{\multicolumn{2}{|c|}{$\begin{array}{c}\text { Precip. } \\
\text { inchs water }\end{array}$}} & \multicolumn{2}{|c|}{ Snow (Min, of drifting) } & \multicolumn{2}{|l|}{ Soll Moist } & \multicolumn{2}{|c|}{ Re1. Hum } & \multirow{2}{*}{\multicolumn{3}{|c|}{$\begin{array}{l}\text { Data collected for Mt, Ecology } \\
\text { Project under conuract with of }\end{array}$}} \\
\hline & Tot. Mi. & Vel. mph. & & & $\mid \overrightarrow{\text { ax, depth }}$ & Min. depth & $5 "-7 "$ & $21 n-13^{n}$ & \multicolumn{2}{|c|}{ Means } & & & \\
\hline$O \subset \tau_{1}$ & 4.168 & 6 & & inchs warer & Var. & $\sigma$ & 3 & 2 & 50 & & & of the $Q$ & rtermaster Gen- \\
\hline \begin{tabular}{|l|} 
Nov, \\
Dec.
\end{tabular} & $\frac{3.643}{7.684}$ & 5 & & 2.5 & 5 & 0 & & & 61 & & & U.S. A & \\
\hline Dec, & $\begin{array}{r}7.684 \\
12.816\end{array}$ & 10 & & 0.6 & Var. & 0 & 3 & $\overline{3}$ & 63 & & & & \\
\hline$\frac{\mathrm{Jan},}{\mathrm{Feb}}$ & $\frac{12.816}{7.423}$ & 17 & & 0.4 & Var. & Var. & 3 & 3 & 61 & & & & \\
\hline Mar. & $\begin{array}{l}7.423 \\
7.682\end{array}$ & 12 & & 0.9 & $\operatorname{Var}$ & Var. & 3 & 3 & 67 & & & fest peric & of consecutive \\
\hline Apr. & $\frac{7.682}{5.751}$ & 10 & & 1.6 & 11 & 0 & & & 59 & & & without & ezing temp. \\
\hline May & 5.751 & 8 & & 2.4 & 3 & 0 & 10 & 7 & 59 & & & & \\
\hline June & $\frac{4,622}{4,944}$ & 6 & & 3.0 & 0 & 0 & 8 & 9 & 62 & & & of first & nd last temp. \\
\hline $\begin{array}{l}\text { Julv } \\
\end{array}$ & $\frac{4.944}{3.244}$ & 7 & & 1.8 & 0 & 0 & 7 & 7 & 59 & & & $832^{\circ}$ & \\
\hline$d u g$ & $\frac{3.244}{3.105}$ & $\frac{4}{4}$ & & 2.6 & 0 & 0 & 7 & 9 & 63 & & & & \\
\hline Sepr. & 5.360 & $\frac{4}{7}$ & & $\frac{2.0}{0.4}$ & 0 & 0 & $\frac{4}{2}$ & $\frac{4}{3}$ & $\frac{62}{53}$ & & & ded bey & $\begin{array}{l}\text { eezring temp. } \\
\text { d final date of }\end{array}$ \\
\hline & & & & & & & & & & & & & \\
\hline
\end{tabular}


TABLE I

University of Colorado - Institute of Arctic \& Alpine Research - Summary of Mountain Environments Station No. C-1 Altitude 10,000 Ft. Exposure Ridge Ton A nnual Summary Oct 1952-0ct 1953

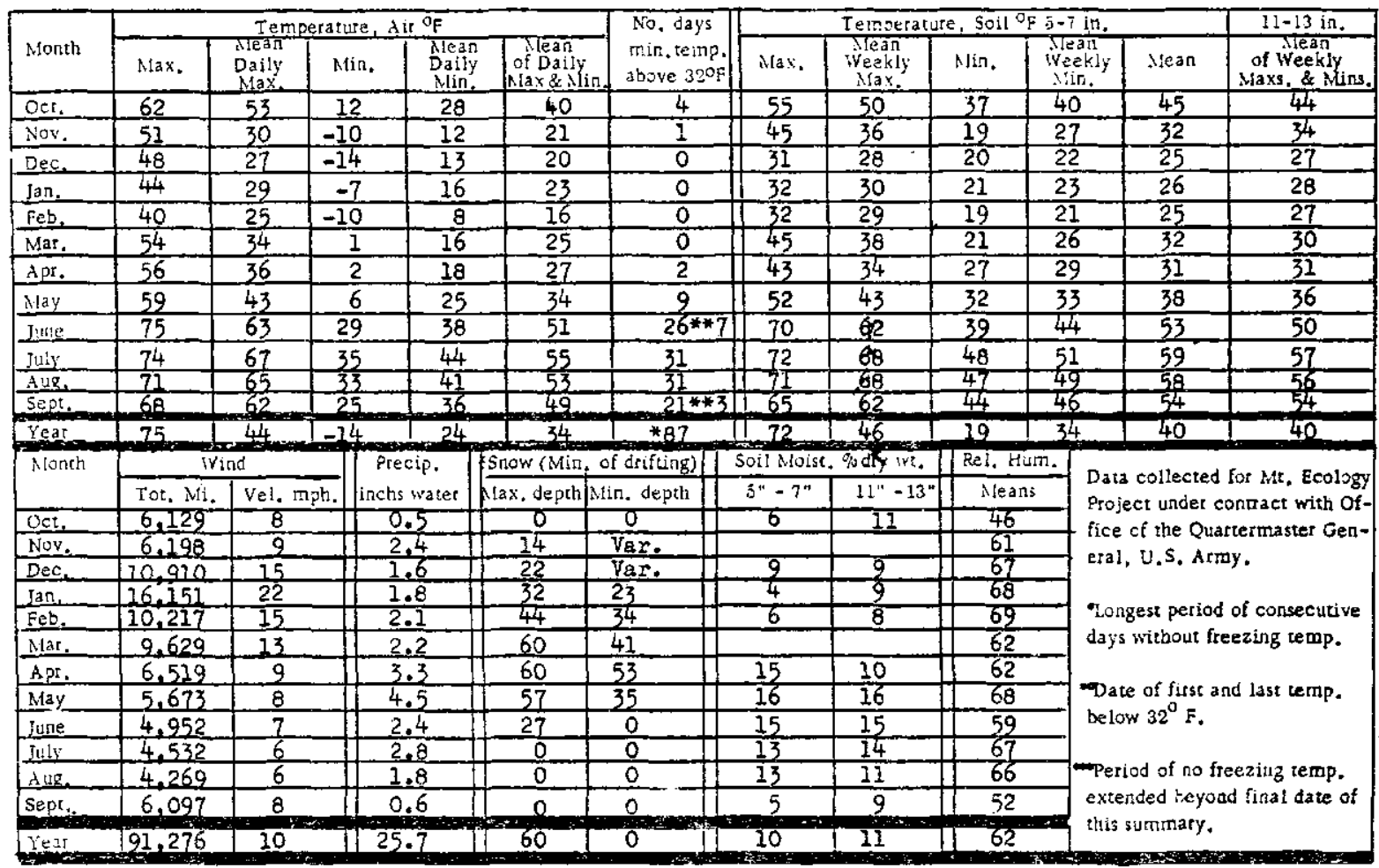


University of Colorado - Institute of Arctic \& Alpine Research - Summary of Mountain Environments Station No. C-3 Altitude 10,000 Fi. Exposure South Annual Summary Oct 1952-Oct 1953

\begin{tabular}{|c|c|c|c|c|c|c|c|c|c|c|c|c|c|}
\hline \multirow[b]{2}{*}{ Month } & \multicolumn{5}{|c|}{ Temperatute, dit ${ }^{\circ} \mathrm{F}$} & \multirow{2}{*}{$\begin{array}{l}\text { No, days } \\
\text { min, teinp. } \\
\text { above } 3 z^{\circ} \mathrm{F}\end{array}$} & \multicolumn{6}{|c|}{ Temperature, soil ${ }^{\circ} \mathrm{F},-7 \mathrm{in}$, } & \multirow{2}{*}{$\begin{array}{c}11-13 \text { in, } \\
\text { of Weekn } \\
\text { Maxs. \& M Mins }\end{array}$} \\
\hline & Max. & \begin{tabular}{l|l} 
Mean & \\
Daily & 1 \\
\end{tabular} & Min. & $\mid \begin{array}{l}\text { Meañ } \\
\text { Daily } \\
\text { Min }\end{array}$ & $\begin{array}{l}\text { Nean } \\
\text { of Daily } \\
\text { Liax sifinin }\end{array}$ & & $\operatorname{Max}$. & $\begin{array}{c}\text { Mean } \\
\text { weekly } \\
\text { Maxy }\end{array}$ & Min, & \multicolumn{2}{|c|}{$\begin{array}{l}\text { Meani } \\
\text { Weekly } \\
\text { Min. }\end{array}$} & Mean & \\
\hline Ocs. & 69 & 58 & 14 & 29 & 43 & 6 & 63 & 58 & 37 & \multicolumn{2}{|l|}{41} & 50 & \multirow{2}{*}{$\frac{45}{34}$} \\
\hline Nov. & 55 & 32 & -8 & 11 & 22 & 0 & 48 & 37 & 25 & \multicolumn{2}{|l|}{30} & 33 & \\
\hline Dec. & 52 & 29 & -13 & 13 & 21 & 0 & 28 & 27 & 21 & \multicolumn{2}{|l|}{22} & 25 & 25. \\
\hline Jan. & 46 & 31 & -5 & 37 & 24 & 0 & 31 & 28 & 18 & \multicolumn{2}{|l|}{21} & 24 & \multirow{2}{*}{$\frac{26}{26}$} \\
\hline $\mathrm{Feb}$, & 42 & 27 & -10 & 9 & 18 & 0 & 30 & 29 & 19 & \multicolumn{2}{|l|}{$\overline{22}$} & 25 & \\
\hline Mar. & 58 & 36 & 1 & 16 & 26 & 0 & 39 & 34 & 23 & \multirow{2}{*}{\multicolumn{2}{|c|}{$\frac{26}{32}$}} & 30 & 30 \\
\hline$A p r$. & 61 & 39 & $I$ & 18 & 29 & 3 & 42 & 34 & 32 & & & $3 \overline{3}$ & 32 \\
\hline Mazy & $\underline{62}$ & 46 & 9 & 25 & 36 & 8 & 55 & 47 & 33 & \multicolumn{2}{|l|}{35} & 41 & 40 \\
\hline June & 80 & 67 & 29 & 39 & 53 & $27 * * 7$ & 73 & 67 & 43 & 47 & & 57 & 54 \\
\hline Iully; & 79 & 70 & 37 & 45 & 58 & 31 & 76 & 71 & 52 & 54 & & 63 & 60 \\
\hline dus. & 77 & 69 & $\frac{34}{34}$ & $\frac{42}{77}$ & 56 & $\frac{31}{31}$ & $\frac{13}{33}$ & 69 & 51 & 53 & & 61 & 58 \\
\hline Segt. & 73 & 66 & 27 & 37 & 52 & $\frac{26 *}{24 *}$ & 67 & 65 & 47 & 50 & & 57 & 5 \\
\hline $7 e 3$ & 80 & 48 & -13 & 25 & 36 & B7 & 76 & 47 & 18 & 36 & & 42 & 40 \\
\hline . Tonth & & $\frac{n d}{n L^{2}}$ & & recip. & Snow (Min & of usiffting) & Soil Noist & dy & Rél. HU & & & ollecte & Me Ecolygyl \\
\hline & Tot. Wir, & Vel, mph. & & :hs water & Max. deprits & fin. depth & $5 n-7^{n}$ & $\therefore i "-13 "$ & Alean & & & it under & Ontract with of \\
\hline$\frac{\mathrm{OCt}_{2}}{\mathrm{Novv_{2 }}}$ & 4.968 & 7 & & $\frac{0.5}{3.3}$ & Var. & 0 & 4 & 3 & 42 & & & of the Q & tremaster Gen- \\
\hline \begin{tabular}{|l} 
Niov, \\
$\mathrm{Dec}_{\text {, }}$
\end{tabular} & $\frac{4.491}{8.177}$ & 6 & & $-\frac{2.3}{2.3}$ & $\frac{12}{16}$ & Var. & & & $\frac{57}{67}$ & & & , U.S. A & y. \\
\hline tan & 12,423 & $\frac{1}{17}$ & & 3.2 & $\frac{10}{23}$ & $\frac{\text { vare }}{17}$ & $\frac{2}{5}$ & $\frac{4}{3}$ & $\frac{61}{69}$ & & & & \\
\hline Fet. & 7.842 & 12 & & 3.0 & 31 & 23 & 6 & $-\frac{5}{3}$ & 68 & & & gest peric & of corsecutive \\
\hline Nas. & 7,484 & 10 & & 3.4 & 37 & 25 & 16 & 16 & 60 & & & without & eezing temp. \\
\hline Apr. & 5.004 & 7 & & 3.6 & 42 & 29 & 20 & 16 & 63 & & & & \\
\hline May & 4,485 & 6 & & 4.6 & 33 & 23 & 15 & 13 & 68 & & & $e$ of first & nd last temp. \\
\hline Jure. & 4,191 & 6 & & 2.6 & 0 & 0 & 11 & 11 & 63 & & & $w 32^{\circ} \mathrm{F}$. & \\
\hline Juin & 3.631 & 5 & & 3.0 & 0 & 0 & 12 & 12 & 68 & & & & \\
\hline 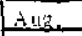 & 3.617 & 5 & & 2.8 & 0 & 0 & 8 & 9 & 65 & & per & lod of ro & eezing temp. \\
\hline Sept. & 4.872 & 6 & & 0.8 & 0 & 0 & 4 & 4 & 53 & & & nded bey & final date of \\
\hline
\end{tabular}


TABLE K

University of Colorado - Institute of Arctic \& Alpine Research - Summary of Mountain Environments Station No C-2___ Alritude 10,000

Exposure North Annual Summary Oct $1952-$-0ct 1953

\begin{tabular}{|c|c|c|c|c|c|c|c|c|c|c|c|c|c|}
\hline \multirow[b]{2}{*}{ Month } & \multicolumn{5}{|c|}{ Temperature, $A$ ir ${ }^{\circ} \mathrm{F}$} & \multirow{2}{*}{$\begin{array}{l}\text { No, days } \\
\text { min, temp. } \\
\text { above } 320 \%\end{array}$} & \multicolumn{6}{|c|}{ Temperature, Soil ${ }^{\circ} \mathrm{F} b+7 \mathrm{in}$, } & \multirow{2}{*}{\begin{tabular}{|c|}
$11-13$ in. \\
$\begin{array}{c}\text { of Wean } \\
\text { Maxs. \& Mly } \\
\text { Mans. }\end{array}$
\end{tabular}} \\
\hline & Max. & \begin{tabular}{l|l} 
Mesh & \\
Daily & Max, \\
\end{tabular} & Min. & $\begin{array}{l}\text { Meat } \\
\text { Dail } \\
\text { Nin } \\
\end{array}$ & $\begin{array}{l}\text { Mean } \\
\text { of Daily } \\
\text { Max \& Alin }\end{array}$ & & Max. & $\begin{array}{c}\text { Mean } \\
\text { Weekly } \\
\text { Nax. }\end{array}$ & Min. & \multicolumn{2}{|c|}{$\begin{array}{l}\text { Meand } \\
\text { Weekly } \\
\text { Min. }\end{array}$} & Mean & \\
\hline Oct. & 64 & 53 & 13 & 27 & 40 & 4 & 49 & 44 & 35 & \multicolumn{2}{|c|}{37} & 41 & 42 \\
\hline Nov. & 52 & 29 & -11 & 10 & 20 & 0 & 40 & 33 & 23 & \multicolumn{2}{|c|}{29} & 31 & 32 \\
\hline Dec, & 51 & 28 & -15 & 24 & 21 & 0 & 27 & 25 & 20 & \multicolumn{2}{|c|}{23} & 24 & 23 \\
\hline Jan, & 46 & 30 & -3 & 17 & 23 & 0 & 29 & 25 & 20 & \multirow{2}{*}{\multicolumn{2}{|c|}{$-\frac{22}{20}$}} & 24 & 24 \\
\hline Feb, & 42 & 25 & -11 & 8 & 16 & 0 & 26 & 25 & 21 & \multirow{2}{*}{\multicolumn{2}{|c|}{$\frac{22}{23}$}} & 23 & 23 \\
\hline Mar. & 55 & 34 & 0 & 15 & 25 & 0 & 32 & 29 & 20 & & & 26 & 27 \\
\hline Apr. & 59 & 38 & 1 & 17 & 27 & 3 & 33 & 32 & 27 & \multicolumn{2}{|c|}{30} & 31 & 31 \\
\hline May & 60 & 45 & \multirow{2}{*}{$\frac{6}{29}$} & 24 & 35 & 3 & 52 & 40 & 31 & \multicolumn{2}{|c|}{33} & 36 & 36 \\
\hline June & 79 & 66 & & 38 & 52 & $23 * * 9$ & 70 & 64 & 41 & \multicolumn{2}{|c|}{45} & 54 & 52 \\
\hline July & 77 & 68 & 34 & 45 & 57 & $3 I$ & 72 & 68 & 49 & \multicolumn{2}{|c|}{53} & 60 & \multirow{2}{*}{$\frac{59}{57}$} \\
\hline$\frac{\text { dug, }}{\text { Sept }}$ & 73 & 67 & 33 & $\frac{41}{87}$ & 54 & $\frac{21}{35}$ & 67 & $\frac{64}{57}$ & 48 & \multicolumn{2}{|c|}{$\frac{51}{44}$} & 58 & \\
\hline Year & & $\frac{63}{46}$ & 20 & 24 & $\frac{20}{35}$ & 85 & $\frac{02}{12}$ & $\frac{21}{42}$ & $\frac{41}{20}$ & 34 & & $\frac{21}{38}$ & 38 \\
\hline Month & IV & & & ip. & Snow (Min. & of drifting) & Soil Moist & $\sigma_{p a d r y ~ \mathrm{vt}}$ & Rel. $\mathrm{HL}$ & & & & \\
\hline & Tot. Mi. & Vel, mph, & & water & Max. depth & din, depth & $5 "-7 n$ & $11^{\prime \prime}-13$ & Mean & & & He & Mt, Eco \\
\hline Oct, & 4.635 & 6 & & & Vare. & 0 & 11 & 10 & 49 & & & $t$ under & stert Gen- \\
\hline Nov, & 4,630 & 6 & & & 14 & Var. & & & 65 & & & the Qu & ștert \\
\hline Dec. & 7.652 & 10 & & & 25 & Var. & 5 & & 60 & & & U.S. As & \\
\hline Jan. & 10.693 & 14 & & & 33 & 25 & 5 & 6 & 65 & & & & \\
\hline Feb. & 7,359 & 11 & & & 45 & 37 & 5 & 6 & 67 & & & gest perio & of consecutive \\
\hline Mar. & 6.814 & 9 & & & 58 & 39 & 12 & 7 & 58 & & & without & \\
\hline Apr. & 4.823 & 7 & & & 59 & 49 & 16 & 15 & 63 & & & & \\
\hline May & 4.218 & 6 & & & 58 & 32 & 13 & 13 & 67 & & & of first a & id last temp. \\
\hline June & 3.620 & 5 & & & 24 & 0 & 15 & 14 & 59 & & belor & $32^{\circ} \mathrm{F}$ & \\
\hline Injy & 3.497 & 5 & & & 0 & 0 & 13 & 14 & 63 & & & & \\
\hline Aug. & 3,272 & 4 & & 9 & 0 & 0 & 10 & 8 & 62 & & & od of no $\mathrm{f}$ & eezing temp. \\
\hline Sept. & 4.549 & 6 & & & 0 & 0 & 7 & 9 & 50 & & & ded be & $d$ final tate of \\
\hline Year & 5,762 & 8 & & & & 0 & LO & 10 & 61 & & & & \\
\hline
\end{tabular}


University of Colorado - Institute of Arctic \& Alpine Research - Summary of Mountain Environments

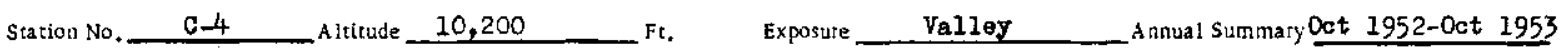




TABLE M

University of Colorado - Institute of Arctic \& Alpine Research - Summary of Mountain Environments Szation No. D-1 A tritude 12,300 $\mathrm{Ft}$. Exposure Ridge Top $A$ nnual Summary Oct 1952-0ct 1953

\begin{tabular}{|c|c|c|c|c|c|c|c|c|c|c|c|c|c|c|}
\hline \multirow[b]{2}{*}{ Month } & \multicolumn{6}{|c|}{ Temperature, dir of } & \multirow{2}{*}{$\begin{array}{l}\text { No. days } \\
\text { min.temp. } \\
\text { above } 320 \%\end{array}$} & \multicolumn{6}{|c|}{ Iemperature, Soll ${ }^{\circ} \mathrm{F}$ D-7 in. } & \multirow{2}{*}{\begin{tabular}{|c|}
$11-13$ in, \\
of Weant \\
Waxs, \& Mins \\
Maxs,
\end{tabular}} \\
\hline & $\operatorname{Max}$ & $\begin{array}{l}\text { Mes } \\
\text { Daily } \\
\text { Max }\end{array}$ & \multicolumn{2}{|c|}{ Min. } & $\begin{array}{l}\text { Mear } \\
\text { Dail } \\
\text { Min }\end{array}$ & $\begin{array}{c}\text { Niean } \\
\text { of Daily } \\
\text { slax \& } \mathrm{N}\end{array}$ & & Max, & $\begin{array}{c}\text { Mean } \\
\text { 'Yeekly: } \\
\text { Alax. }\end{array}$ & Min. & \multicolumn{2}{|c|}{$\begin{array}{l}\text { Treali } \\
\text { iveekly } \\
\text { slin. }\end{array}$} & Mlean & \\
\hline Oct. & 50 & 41 & \multicolumn{2}{|c|}{9} & 27 & 34 & 5 & 41 & 36 & 31 & \multicolumn{2}{|c|}{32} & 34 & 34 \\
\hline Nov. & 32 & 18 & \multicolumn{2}{|c|}{-18} & 7 & 13 & 0 & 32 & 28 & 14 & \multicolumn{2}{|c|}{22} & 25 & 27 \\
\hline Dec, & 34 & 35 & \multicolumn{2}{|c|}{-10} & 5 & 10 & 0 & 23 & 21 & 11 & \multicolumn{2}{|c|}{24} & 27 & 18 \\
\hline Jan. & 32 & 18 & \multicolumn{2}{|c|}{-3} & 8 & 13 & 0 & 22 & 20 & 12 & \multicolumn{2}{|c|}{14} & 17 & 12 \\
\hline Feb & 24 & 13 & \multicolumn{2}{|c|}{-15} & 1 & 7 & 0 & 21 & 18 & 6 & \multicolumn{2}{|c|}{10} & 24 & 15 \\
\hline Mar. & 41 & 21 & \multicolumn{2}{|c|}{-9} & 2 & 25 & 0 & 27 & 22 & 11 & \multicolumn{2}{|c|}{14} & 18 & 18 \\
\hline Apr. & 47 & 23 & \multicolumn{2}{|c|}{-4} & 11 & 17 & 0 & 30 & 26 & 25 & \multicolumn{2}{|c|}{19} & 22 & 23 \\
\hline May & 46 & 32 & \multicolumn{2}{|c|}{5} & 19 & 26 & 2 & 35 & 32 & 23 & \multicolumn{2}{|c|}{27} & 30 & 29 \\
\hline June & 61 & 51 & \multicolumn{2}{|c|}{25} & 36 & 44 & $20 * 25$ & 48 & 44 & 32 & \multicolumn{2}{|c|}{34} & 39 & 37 \\
\hline July & 62 & 55 & \multicolumn{2}{|c|}{35} & 41 & 48 & 31 & 53 & 51 & 42 & \multicolumn{2}{|c|}{43} & 47 & 45 \\
\hline A ug. & 57. & 51 & 32 & & 37 & 44 & $28+4$ & 52 & 49 & 41 & 42 & & $\frac{36}{46}$ & $\frac{75}{45}$ \\
\hline Sept. & 57 & 49 & 23 & & 34. & 41 & $\frac{5}{18}$ & 48 & $\frac{76}{46}$ & $\frac{16}{37}$ & $\frac{-165}{35}$ & & $\frac{90}{43}$ & 42 \\
\hline Year & 62 & 32 & 10 & & 20 & 26 & & 53 & 33. & 6 & 26 & & 29 & 29 \\
\hline Month & $\mathrm{ivi}$ & & & Pre & & Snow (Min. & of drifting) & Soil kloist & $F_{\%}$ ory $w^{w T}$ & Rel. H & & & & \\
\hline & Tor, Mi. & vel, mp & & inchs & water & ax, deprih & Min, depth & $5^{n}-7^{n}$ & $11 "+13 n$ & Alea & & & d & for At, Ecology \\
\hline Oct. & 12,398 & 17 & & & & Var. & 0 & & & $\underline{46}$ & & & the ou & rermaster Gen- \\
\hline Nov. & 73,727 & $\frac{22}{24}$ & & & & Vare & Var. & $\frac{22}{26}$ & $\frac{18}{8}$ & $\frac{71}{70}$ & & & U.S. Ar & \\
\hline Dec, & 17.789 & 24 & & & & $\operatorname{Var}$ & Vare. & 26 & 8 & 70 & & & & \\
\hline \begin{tabular}{|l} 
Jan, \\
Feb.
\end{tabular} & $-\frac{22.093}{16.746}$ & $\frac{30}{25}$ & & $\frac{2}{3}$ & & Var. & Var. & $\frac{39}{23}$ & $\frac{15}{17}$ & $\frac{88}{85}$ & & & gest perior & of consecutive \\
\hline Mar. & $\frac{10.140}{16.441}$ & $\frac{22}{22}$ & & $\frac{1}{2}$ & & Yare & Yare & 23 & 17. & $\frac{185}{70}$ & & & withour $f$ & eezing temp. \\
\hline Apr. & 14,057 & 20 & & 2 & & Yaes. & Var. & 21 & 14 & 81 & & & & \\
\hline May & 10,725 & 14 & & $\sqrt{3}$ & & Var. & Vax, & 33 & 18 & 77 & & & of first 2 & ad last temp. \\
\hline June. & 8.591 & 12 & & 2 & & 0 & 0 & 42 & 20 & 57 & & & $32^{\circ} \mathrm{F}$ & \\
\hline Iulv & 6.981 & 9 & & 4 & & 0 & 0 & 47 & 20 & 63 & & & & \\
\hline A & 8.462 & 11 & & 3 & & 0 & 0 & 36 & 20 & 68 & & & od of not & eezing tecap. \\
\hline Sept. & 11,626 & 15 & & 0 & & 0 & 0 & & & 50 & & & ided beyo & d final date of \\
\hline Year & 9,636 & 19 & & & & & & & & & & & & \\
\hline
\end{tabular}


University of Colorado - Institute of Arctic \& Alpine Research - Summary of Mountain Environments

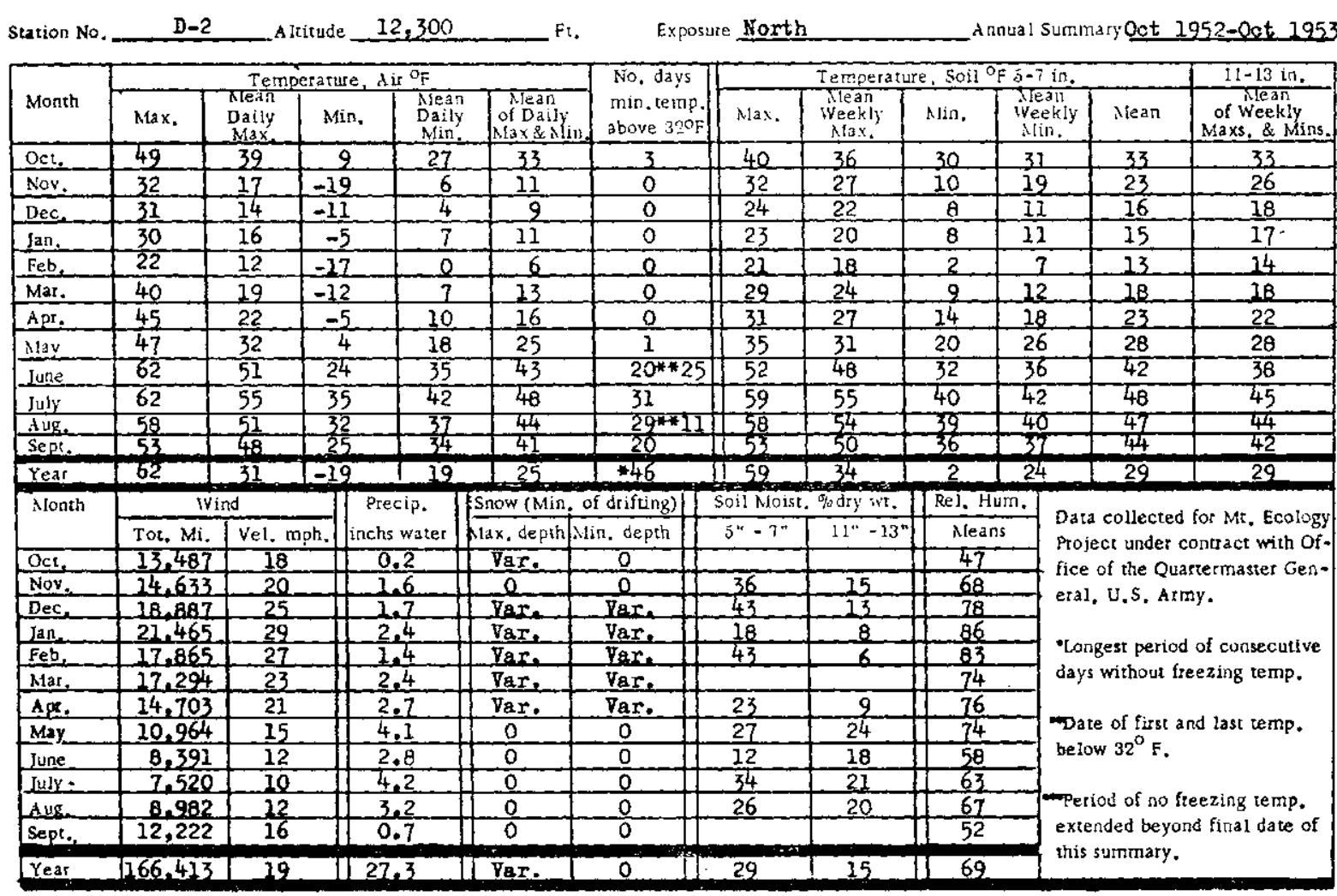


TABLE 0

University of Colorado - Institute of Arctic \& Alpine Research - Summary of Mountain Environments

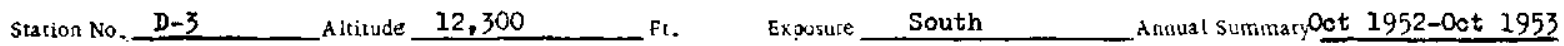

\begin{tabular}{|c|c|c|c|c|c|c|c|c|c|c|c|c|c|}
\hline \multirow[b]{2}{*}{ Month } & \multicolumn{5}{|c|}{ Temperarure, $\lambda$ ir ${ }^{\circ} \mathrm{F}$} & \multirow{2}{*}{$\begin{array}{l}\text { No, days } \\
\text { min, teinp. } \\
\text { above } 320 \mathrm{~F}\end{array}$} & \multicolumn{6}{|c|}{ Temperature, soil ${ }^{\circ} \mathrm{F} F-7$ in, } & \multirow{2}{*}{\begin{tabular}{|c|}
$11-13$ in. \\
$\begin{array}{c}\text { Whean } \\
\text { Weekly } \\
\text { Maxs. \& Mins. }\end{array}$
\end{tabular}} \\
\hline & Max. & \begin{tabular}{l|l} 
Meaily \\
Dax \\
Max
\end{tabular} & Min. & n. $\begin{array}{c}\text { Arear } \\
\text { Daily } \\
\text { Mliil }\end{array}$ & $\begin{array}{c}\text { Sean } \\
\text { of Daily } \\
\text { Max \& } 1\end{array}$ & & Max. & $\begin{array}{c}\text { Mlean } \\
\text { Weekly } \\
\text { Mlax. }\end{array}$ & Min. & \multicolumn{2}{|c|}{$\begin{array}{l}\text { Theant } \\
\text { iveethy } \\
\text { Nin. }\end{array}$} & sean & \\
\hline Oct. & .52 & 42 & 10 & 26 & 34 & 4 & 48 & 42 & 29 & 32 & & 37 & 37 \\
\hline Nov. & $3 / 4$ & 18 & -20 & 6 & 12 & 0 & 36 & 30 & 10 & 22 & & 26 & 28 \\
\hline Dec, & 36 & 15 & -11 & 4 & 9 & 0 & 25 & 22 & $\overline{8}$ & 11 & & 16 & 19 \\
\hline Jan. & 32 & 17 & -4 & 7 & 12 & 0 & 23 & 20 & 10 & 13 & & 17 & 18 \\
\hline Feb, & 26 & 13 & \multirow{2}{*}{-17} & 1 & 7 & 0 & 21 & 19 & 2 & 12 & & 25 & 17 \\
\hline Mar. & 40 & 20 & & $\theta$ & 24 & 0 & 26 & 22 & 17 & 18 & & 20 & 19 \\
\hline $\mathrm{Apr}$. & 45 & 22 & $\frac{-10}{-06}$ & $g$ & 16 & 0 & 28 & 25 & 21 & 22 & & 24 & 24 \\
\hline Nay & 47 & 32 & 5 & 19 & 26 & 2 & 33 & 30 & 24 & 27 & & 28 & 28 \\
\hline Jine & 61 & 50 & 25 & 35 & 43 & $19 * * 25$ & 52 & 48 & 32 & 36 & & 42 & 37 \\
\hline July & 61 & 55 & 34 & 40 & 48 & 31 & 59 & 55 & 42 & 44 & & 49 & 46 \\
\hline hug, & 57 & 52 & \multirow{2}{*}{$\frac{31}{24}$} & 37 & 4 & $2 \theta * * 11$ & 58 & 54 & 41 & $4 \overline{3}$ & & 48 & 46 \\
\hline$\frac{\text { Sepr. }}{\text { Year }}$ & 57 & $\frac{51}{32}$ & & $\frac{34}{19}$ & $\frac{42}{26}$ & $\frac{19}{* 45}$ & $\frac{55}{59}$ & $\frac{52}{35}$ & 40 & $\frac{41}{27}$ & & 46 & $\frac{45}{37}$ \\
\hline \multirow[t]{2}{*}{ Month } & \multirow{2}{*}{\multicolumn{2}{|c|}{$\frac{\text { Wind }}{\text { Tot Mi } / V_{e l} \mathrm{mph}}$}} & \multirow{2}{*}{\multicolumn{2}{|c|}{ 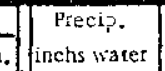 }} & Snow (Min. & of drifting) & \multirow{2}{*}{$\frac{\text { Scil Moist }}{5 "-7 "}$} & 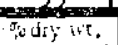 & \multicolumn{2}{|c|}{ Rel, Fum. } & & & \\
\hline & & & & & $\sqrt{\operatorname{tax} . \text { depth }}$ & Mirl, depth & & $11 "-13 "$ & inest:s & & & & \\
\hline Oct. & 10,377 & 14 & \multicolumn{2}{|c|}{\begin{tabular}{l||l|} 
ph. & inchs water \\
\end{tabular}} & 0 & 0 & & & 44 & & & & \\
\hline Nov, & 11.688 & 14 & & 2.3 & Var. & Var. & 19 & 15 & 68 & & & & \\
\hline Dec. & 15.869 & 21 & & 2.9 & Var. & Iar. & 13 & 16 & 78 & & & & \\
\hline Jan, & 19,692 & 27 & & 5.3 & Far. & Var. & 14 & 15 & 86 & & & & \\
\hline Feb. & 14,856 & 22 & & 3.1 & Var. & Var. & 8 & 9 & $88^{4}$ & & & gest perioc & of cunsecutive \\
\hline jar. & 14,522 & 19 & & 4.0 & Var. & Var. & & & 72 & & days & without $\mathrm{fr}$ & ezing temp. \\
\hline Apr. & 12,414 & 17 & & 3.1 & Var. & $\operatorname{Var}$. & 10 & 8 & 73 & & & & \\
\hline May & 9,819 & 13 & & 4.6 & 0 & 0 & 58 & 33 & 72 & & & te of first a & Id last temp. \\
\hline June & 8,120 & 11 & & 2.2 & 0 & 0 & 36 & 33 & 56 & & & $w .32^{\circ}$ & \\
\hline$\Delta u b_{1}$ & 6.397 & 8 & & 3.4 & 0 & 0 & 42 & 29 & 62 & & & & \\
\hline dug. & 7,580 & 10 & & 3.0 & 0 & 0 & 34 & 18 & 67 & & & iod of nof & eezing temp. \\
\hline sepr. & 9,884 & 13 & & 0.6 & 0 & 0 & & & 49 & & & led beyo & final date of \\
\hline & 7070 & & & 34 & 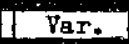 & & & 20 & & & & & \\
\hline
\end{tabular}


University of Colorado - Institute of Arctic \& Alpine Research - Summary of Mountain Environments Station No _ D -4 $\mathrm{Ft}$. Exposure Feller A nлual Summary Oct 1952-Oct 1953

\begin{tabular}{|c|c|c|c|c|c|c|c|c|c|c|c|c|c|}
\hline \multirow[b]{2}{*}{ Month } & \multicolumn{5}{|c|}{ Temperature, $d$ ir of } & \multirow{2}{*}{$\begin{array}{l}\text { No. days } \\
\text { min. te mp. } \\
\text { above } 32 \circ \mathrm{F}\end{array}$} & \multicolumn{6}{|c|}{ Temperature, 5 oil ${ }^{\circ} \mathrm{F} 5-7$ in. } & \multirow{2}{*}{$\begin{array}{c}11-13 \mathrm{in}, \\
\text { Menan } \\
\text { of Weekly } \\
\text { Maxs, \& Mins, }\end{array}$} \\
\hline & $\mathrm{Max}_{*}$ & $\begin{array}{l}\text { Rean } \\
\text { Paily } \\
\text { Mdax. }\end{array}$ & Min. & $\begin{array}{l}\text { Mean } \\
\text { Dally } \\
\text { Min }\end{array}$ & $\begin{array}{c}\text { Mean } \\
\text { of Daily } \\
\text { Alax \& Al }\end{array}$ & & Mas, & $\begin{array}{c}\text { Meant } \\
\text { Werky: } \\
\text { Max. }\end{array}$ & $\operatorname{Ain}_{\alpha}$ & \multicolumn{2}{|c|}{$\begin{array}{l}\text { Meena } \\
\text { Weekly } \\
\text { Nlin. }\end{array}$} & Mean & \\
\hline Oct. & 54 & 43 & 12 & 29 & 36 & 10 & 45 & 38 & 31 & 33 & & 36 & 36 \\
\hline Nov, & 34 & 21 & -15 & 8 & 15 & 0 & 33 & 31 & 20 & 27 & & 29 & 31 \\
\hline Dec. & 36 & 17 & -14 & 6 & 12 & 0 & 26 & 25 & 14 & 17 & & 21. & 22 \\
\hline Jan, & 32 & 20 & & 10 & 15 & 0 & 24 & 22 & 14 & 16 & & 19 & 19 \\
\hline Feb. & 27. & 15 & \multirow{2}{*}{-14} & $\overline{3}$ & 9 & 0 & 23 & 20 & 11 & 13 & & 17 & 17 \\
\hline Mar. & 42 & 23 & & ji2 & 17 & 0 & 30 & 25 & 14 & 16 & & 20 & 20 \\
\hline Apr. & 48 & 26 & -1 & 13 & 20 & 0 & 31 & 28 & 19 & 22 & & 25 & 25 \\
\hline May. & 52 & 36 & 4 & 20 & 28 & 3 & 34 & 32 & 24 & 30 & & 31 & 31 \\
\hline June & 62 & 52 & 27 & 37 & 45 & $19^{n-25}$ & 51 & 47 & 33 & 36 & & 42 & 37 \\
\hline July & 65 & 57 & 36 & 43 & 50 & 31 & 57 & 54 & 44 & \multicolumn{2}{|l|}{45} & 49 & 47 \\
\hline \multirow{2}{*}{\multicolumn{12}{|c|}{\begin{tabular}{|l} 
Seput. \\
\end{tabular}}} & 48 & 47 \\
\hline & & & & & & & & & & & & & \\
\hline Year & 6 & & $=$ & & 28 & & 52 & 35 & 11 & \multicolumn{2}{|l|}{41} & 32 & 31 \\
\hline \multirow[t]{2}{*}{ Nonth } & \multicolumn{2}{|c|}{ Yind } & \multirow{2}{*}{\multicolumn{2}{|c|}{\begin{tabular}{|l|} 
Precip. \\
finchs w-ater
\end{tabular}}} & Snow (Min, & of drifting) & Soil Mroist & godry ixt. & \multirow{2}{*}{\multicolumn{2}{|c|}{$\begin{array}{l}\text { Rel. Hum, } \\
\text { Neans }\end{array}$}} & \multirow{5}{*}{\multicolumn{3}{|c|}{$\begin{array}{l}\text { Data cotlected for Mt, Ecology } \\
\text { Project under contract with of- } \\
\text { fice of the Quartermaster Gen- } \\
\text { eral, U.S. Artmy. }\end{array}$}} \\
\hline & Tot, Mi, & Vel. mph & & & Sax, depth & firt, depth & $5 "-7 n$ & $11^{\prime \prime}-13$ & & & & & \\
\hline Oet. & 11.857 & 16 & \multirow{2}{*}{\multicolumn{2}{|c|}{0.4}} & Var. & 0 & 34 & $\frac{26}{17}$ & & & & & \\
\hline Nov, & 22.845 & 29 & & & Vare & Fare & 32 & 17 & & & & & \\
\hline Dec, & 75,074 & 20 & & 2.4 & Yax. & Tere & 37 & 52 & & & & & \\
\hline$\frac{\mathrm{Jan},}{\mathrm{Feb}}$ & 21.006 & 28 & & 3.2 & Far. & Fare & 49 & 29 & & & & & I of consecuttve \\
\hline Feb, & 14.561 & 22 & & 2.8 & Faxe & Fare & 34 & 36 & & & & per & or congective \\
\hline Mar. & 13,209 & 28 & & 3.3 & Yax. & Yer. & 25 & 27 & & & & & \\
\hline A $A \mathrm{p}$, & 12.852 & 18 & & 3.4 & Yar. & Yar. & 45 & 21 & & & & & \\
\hline May & 8.359 & I1 & & 4.3 & 0 & 0 & 51 & 35 & & & & of first & nd last cemp. \\
\hline June & $6,2 B 2$ & 9 & & 2.8 & 0 & 0 & 29 & 18 & & & & $32^{\circ} \mathrm{F}$. & \\
\hline july & 6.333 & 9 & & 2.9 & 0 & 0 & 51 & 25 & & & & & \\
\hline Aug. & $7.9+6$ & 11 & & 3.7 & 0 & 0 & 40 & 26 & & & & od of no $f$ & eezing temp. \\
\hline sepe, & 10,553 & 14 & & 0.7 & 0 & 0 & 22 & I9 & & & & aded beyo & d final date of \\
\hline
\end{tabular}




\section{SUGgestions TO CONTRIBUTORS}

1. Manuscript is to be typewritten on one side of paper $8 \frac{1}{2}$ x 11 inches, double spaced and with ample-margins; carbon copies are not acceptable.

2. Do not underline any words in the typewritten sheets except titles of books or magaxines.

3. Certain words with variable spellings may be standardized as follows: co-author, co-operate, death rate, guinea-pig, high school (noun), high-school (adjective), man-like, per cent, percentage, program, so-called, subclass, tert-book, theater, today, X-rays, zoology.

4. If in doubt as to beginning a word with a capital, use a small letter; the editor can easily change it if change is needed. Capitals are less used now than formerly.

5. Punctuation should follow approved English usage. Among other points this requires a comma before and in a series of words and a comma before and or but introducing part of a compound sentence. The colon is seldom used except just before a series of nouns, adjectives, or phrases. Use the dash only as follows: (1) to set off parenthetical expressions too long and emphatic for commas, but not grammatically independent; (2) to precede an explanation appended as an appositive at the end of a sentence, e.g., This was the practice of the tribe - a practice established for many centuries. Distinguish by double length a dash from a hyphen. titles.

6. Do not put a period after the title of your article or after any of the centered sub-

7. Save expense of footnotes by putting footnote material, if possible, into the tert. When footnotes are used, they are to be numbered consecutively through an entire article or entire chapter. Footnotes should be typed one after the other on a separate sheet, not interspersed with text or put at the bottoms of the manuscript pages. The first line of a footnote is always indented.

8. References, whether in literature cited, bibliography, or footnotes should all be made consistent as to order of author's name, subject, name of publication, volume number, page, and date. See recent numbers of Shudies for acceptable styles to employ.

9. The Shudies does not indent quoted paragraphs; hence in the manuscript they should be full width. Never indent anything in prose except the first line of a paragraph.

10. Tables are to be without ruled lines. They should be typed on sheets separate from the text. Please reduce tables to a minimum.

11. Since printing is expensive, avoid unnecessary material, especially tables and long lists which are of little interest except to the author.

12. If it is desired to use line drawings or photographs, consult the editor before preparing them.

13. If the article is one for which a summary can be prepared it is highly desirable to make a summary, having it somewhat $!$ is than one page in length. 


\section{UNIVERSITY OF COLORADO STUDIES}

\section{Publication to Date}

General Series (A): Volumes 1-29 complete. (Discontinued. Last issue, March, 1957.) Series B: Studies in the Humatties: Volumes 1-2 complete. (Discontinued. Last iene, October, 1945.)

Series C: Studies in the Social Sciences: Volume $\{$ complete. (Discontinued. Last inare, November, 1946.)

Series D: Physical and Biological Sciences: Volumes 1-2 complete. (Discontinued. Lat issue, April, 1947.)

\section{Revised Series}

Series in Anthropology Nos. 1 and 2 (1948); No. 3 (1951); No. 4 (1954); No. 5 (1955); No. 6 (195i); No. 7 (1958)

Series in Biology No. 1 (1950); Nos. 2 and 3 (1955); No. 4 (1958); Nos. 5 and 6 (1959); Nos. 7 and 8 (1961)

Series in Chemistry and Pharmacy No. 1 (1952); No. 2 (1959); No. 3 (1901)

Series in Economics No. 1 (1950); No. 2 (1955); No. 3 (1959)

Series in History No. 1 (19.49); No. 2 (1961)

Series in Language and Literature No. 1 (1948); No. 2 (1949), No. 3 (1952); Noo. 4 (1953); No. 5 (1954); No. 6 (1957); No. 7 (1959)

Series in Philosophy No. 1 (1958); No. 2 (1961)

Series in Political Science No. 1 (1953)

Series in Sociology No. 1 (1949); No. 2 (1950); No. 3 (1957) 